ANDRÉ JAVIER FERREIRA PAYAR

\title{
A ESCRAVIDÃO ENTRE OS SEGUROS: \\ AS SEGURADORAS DE ESCRAVOS NA PROVÍNCIA DO RIO DE JANEIRO \\ (1831-1888)
}

Dissertação de Mestrado

Orientador: Prof. Associado José Reinaldo de Lima Lopes

UNIVERSIDADE DE SÃO PAULO

FACULDADE DE DIREITO

SÃO PAULO

2012 


\section{A ESCRAVIDÃO ENTRE OS SEGUROS: AS SEGURADORAS DE ESCRAVOS NA PROVÍNCIA DO RIO DE JANEIRO \\ (1831-1888)}

Dissertação de Mestrado apresentada ao Programa de PósGraduação da FDUSP como requisito parcial à obtenção do grau de Mestre na área de concentração de Filosofia e Teoria Geral do Direito, sob a orientação do Prof. Associado José Reinaldo de Lima Lopes 


\title{
FOLHA DE APROVAÇÃO
}

André Javier Ferreira Payar

\author{
A ESCRAVIDÃO ENTRE OS SEGUROS: \\ AS SEGURADORAS DE ESCRAVOS NA PROVÍNCIA DO \\ RIO DE JANEIRO \\ (1831-1888)
}

\begin{abstract}
Dissertação de Mestrado apresentada ao Programa de Pós-Graduação da FDUSP como requisito parcial à obtenção do grau de Mestre na área de concentração de Filosofia e Teoria Geral do Direito, sob a orientação do Prof. Associado José Reinaldo de Lima Lopes
\end{abstract}

Área de concentração: Filosofia e Teoria Geral do Direito

\section{Banca Examinadora:}

Prof (a). Dr (a).

Instituição:

Prof (a). Dr (a).

Instituição:

Prof (a). Dr (a).

Instituição:

São Paulo, 


\title{
RESUMO
}

O comércio internacional utilizou-se largamente dos seguros como forma de resguardar, total ou parcialmente, o capital inicialmente investido nas expedições marítimas. Os investidores e realizadores do comércio transatlântico de escravos, um empreendimento capitalista, computaram os custos dos seguros marítimos dentre os gastos iniciais de qualquer viagem negreira. A travessia do Atlântico reservava à navegação uma soma razoável de riscos, que deveriam ser contornados. Por outro lado, a partir de uma época já próxima à abolição do tráfico negreiro, a sociedade carioca do século XIX, e também a sociedade norte-americana de meados da década de 1840, foram testemunhas do surgimento de companhias que tomaram a vida dos escravos como objeto de outra espécie de seguros: garantiram os patrimônios dos senhores contra os eventuais desfalques provocados pelas mortes de suas propriedades. Uma vez que não foram objeto de preocupação dos estudos historiográficos nacionais e internacionais, esta pesquisa procede à identificação destas companhias brasileiras, em sua maioria estabelecidas nas décadas de 1850 e de 1870. Um trabalho exploratório, enfim, em que seus negócios vão apresentados de modo a transparecer as influências sofridas por duas datas importantes ao processo da abolição da escravatura no Brasil.

Palavras-chave: Brasil. Século XIX; História do Direito; História dos Seguros; sociedade mercantil; escravidão.

\begin{abstract}
International trade appears to have largely used as a kind of insurance to safeguard, in whole or in part, the initial capital investment in ocean expeditions. Apparently, investors and accomplishers of the transatlantic slave trade, a capitalist enterprise, computed the cost of marine insurance from the initial expenses of any trip. Crossing the Atlantic Ocean could give rise to a reasonable sum of navigation hazards that should be avoided. On the other hand, from a time close to the abolition of the slave trade, Rio de Janeiro's society of the nineteenth century, and also the American society of the mid-1840s, witnessed the emergence of companies that took the lives of slaves as an object of another kind of insurance: ensuring the wealth of masters against possible embezzlement caused by deaths of their properties. Since there have not been a concern of national and international historiographical studies on this matter, this research proposes to identifies these Brazilian companies, mostly established in the 1850 s and 1870s. This is an exploratory work that presents companies' business in order to show the influences suffered on two of the most important dates in the process of abolition of slavery in Brazil.
\end{abstract}

Keywords: Brazil. $19^{\text {th }}$ Century; Legal History; Insurance History; mercantile society; slavery. 


\section{AGRADECIMENTOS}

Sou muito grato ao Prof. José Reinaldo de Lima Lopes, não só pela orientação a esta pesquisa, mas também pela paciência e por todas as oportunidades de aprendizado que vieram com as conversas e com as tarefas realizadas ao longo de todos esses anos de convivência. Agradeço por me permitir aprender com sua experiência, enquanto investigava, enquanto trabalhava.

Agradeço ao Prof. José Alexandre Tavares Guerreiro, do Departamento de Direito Comercial da FDUSP, e ao Prof. Rafael de Bivar Marquese, do Departamento de História da FFLCH-USP, pela disponibilidade, pelas críticas e pelas sugestões oportunas encaminhadas ao trabalho quando nos reunimos, em abril de 2011, durante a Banca de Qualificação.

Agradeço, por fim, aos funcionários da Biblioteca Central da FDUSP, da Biblioteca da FFLCH-USP, da Biblioteca da FEA-USP, do Instituto de Estudos Brasileiros/ IEB-USP, do Arquivo Nacional do Rio de Janeiro, e a todos os que, direta ou indiretamente, participaram em algum momento dos processos de pesquisa e elaboração desta dissertação. 


\section{ÍNDICE}

INTRODUÇÃO

CAPÍTULO 1:

O TRÁFICO SEGURO NA PROVÍNCIA DO RIO DE JANEIRO - PRIMEIRA METADE DO SÉCULO XIX ............................................................................... 28

1. Com a Corte, a Grã-Bretanha …………………………………………….... 28

2. Com a Corte, o Comércio ................................................................................. 37

2.1. O Café e o tráfico …………………………………........................ 45

2.2. O Tráfico e os seguros ……………………………………………. 50

CAPÍTULO 2:

O MERCADO SEGURADOR DA PRAÇA COMERCIAL DO RIO DE JANEIRO -

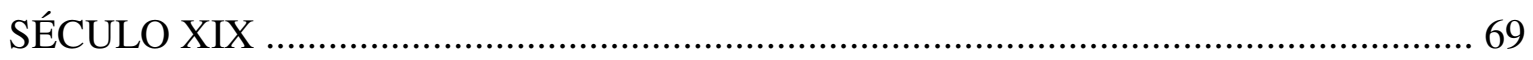

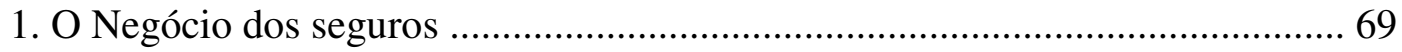

1.1. As Primeiras companhias de seguros e o negócio do tráfico .............. 79

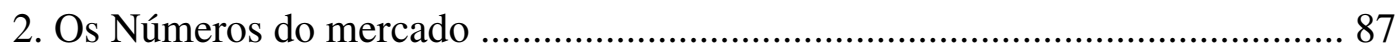

3. O Tratamento dispensado aos seguros pela doutrina jurídica de ponta a ponta do oitocentos

\section{CAPÍTULO 3:}

AS COMPANHIAS SEGURADORAS DE VIDA DE ESCRAVOS NO MERCADO

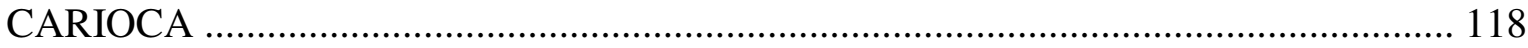

1. Dentre os seguros terrestres, o seguro de vida ................................................ 118

2. As Companhias de seguros de vida de escravos, desde meados do século XIX 


\section{ANEXOS}

Anexo 1:

Quadro da legislação sobre seguros (séculos XVII, XVIII e XIX)

Anexo 2:

Quadro Companhias de Seguros em funcionamento na Província do Rio de Janeiro (18081889)

Anexo 3:

Considerações ao Quadro Companhias de Seguros em funcionamento na Província do Rio de Janeiro (1808-1889) (Anexo 2)

Anexo 4:

Quadros diretivo e administrativo, e endereços das Companhias seguradoras de vida de escravos autorizadas a funcionar na Província do Rio de Janeiro (1808-1889) 225

Anexo 5:

Modelo de apólice da Companhia de Seguros Feliz Lembrança para a contratação de seguros de vida de escravos 


\section{ÍNDICE DE TABELAS E GRÁFICOS}

Tabela 1:

Companhias de seguros estabelecidas em cada década do período 1808-1889 88

Gráfico 1:

Companhias de Seguros estabelecidas na Província do Rio de Janeiro (1808-1888) 93

Gráfico 2:

Companhias de Seguros nacionais e estrangeiras estabelecidas na Província do Rio de Janeiro (1808-1889) 94

Tabela 2:

Companhias de seguros nacionais e estrangeiras estabelecidas em cada década do período 1808-1889 98

\section{Gráfico 3:}

Nacionalidades das Companhias de Seguros estrangeiras estabelecidas na Província do Rio de Janeiro (1808-1889) 99

Gráfico 4:

Nacionalidades das principais Companhias de Seguros estrangeiras estabelecidas na Província do Rio de Janeiro (1843-1889) 100

\section{Gráfico 5:}

Riscos segurados pelas Companhias de Seguros estabelecidas na Província do Rio de Janeiro (1808-1889) 102

\section{Gráfico 6:}

Riscos segurados pelas Companhias de Seguros nacionais e estrangeiras estabelecidas na Província do Rio de Janeiro (1808-1889) 102 


\section{Gráfico 7:}

Riscos segurados pelas Companhias nacionais que foram se estabelecendo, ano a ano, na Província do Rio de Janeiro (1808-1889)

\section{Gráfico 8:}

Riscos segurados pelas Companhias estrangeiras que foram se estabelecendo, ano a ano, na Província do Rio de Janeiro (1843-1889) 105

Gráfico 9:

Companhias de Seguros em funcionamento da Província do Rio de Janeiro (1808-1888)

Gráfico 10:

Companhias de Seguros nacionais e estrangeiras em funcionamento na Província do Rio de Janeiro (1808-1888) 111

Gráfico 11:

Companhias seguradoras de riscos marítimos e terrestres em funcionamento na Província do Rio de Janeiro (1808-1888) 112

Tabela 3:

Companhias seguradoras de vida de escravos autorizadas a funcionar na Província do Rio de Janeiro (1808-1888) 138

\section{Gráfico 12:}

Companhias seguradoras de vida de escravos comparadas ao total das Companhias seguradoras de riscos terrestres, em funcionamento na Província do Rio de Janeiro (18081888) 139

Gráfico 13:

Companhias seguradoras de vida de escravos comparadas ao total das Companhias seguradoras nacionais de riscos terrestres, em funcionamento na Província do Rio de Janeiro (1808-1888) 
Gráfico 14:

Companhias seguradoras de vida de escravos comparadas ao total das Companhias seguradoras, em funcionamento na Província do Rio de Janeiro (1808-1888)

\section{Gráfico 15:}

Companhias seguradoras de vida de escravos comparadas ao total das Companhias seguradoras nacionais, em funcionamento na Província do Rio de Janeiro (1808-1888)

Gráfico 16:

Companhias seguradoras de vida de escravos comparadas ao total das Companhias seguradoras, estabelecidas anualmente na Província do Rio de Janeiro (1808-1888) .. 145

Gráfico 17:

Companhias seguradoras de vida de escravos comparadas ao total de Companhias seguradoras nacionais, estabelecidas anualmente na Província do Rio de Janeiro (18081888)

Tabela 4:

Decretos e demais normas referentes às Companhias de Seguros de vida de escravos autorizadas a funcionar na província do Rio de Janeiro, século XIX 150

Tabela 5:

Capital e destino dos fundos das Companhias seguradoras de vida de escravos autorizadas a funcionar na Província do Rio de Janeiro

Tabela 6:

Condições impostas pelas Companhias seguradoras de vida de escravos para a realização dos seguros 166 


\section{INTRODUÇÃO}

Pelo menos durante a primeira metade do século XIX, o tráfico transatlântico de escravos bem pode ter sido considerado um empreendimento capitalista. Um negócio, enfim, que de alguma forma atraiu a atenção dos negociantes em busca de investimentos seguros para a aplicação de seu capital disponível: investimentos que lhes rendessem lucros razoáveis. Mas, como qualquer outra atividade comercial, o empreendimento negreiro também fora uma atividade por si só repleta de riscos e, como qualquer outro negócio dependente da navegação marítima, o sucesso do tráfico estivera à mercê da ocorrência das avarias, dos abandonos de navios, dos naufrágios, etc., do mesmo modo que estivera sujeito à capacidade dos capitalistas, e portanto do mercado, em dar respostas às suas necessidades. Tempestades, incêndios, ou mesmo a rebeldia dos cativos em plena travessia do Atlântico, tudo isso poderia por a fundo qualquer esperança capitalista de se extrair as maiores taxas de lucros possíveis de cada uma das viagens negreiras. E para que todos esses riscos fossem evitados, ou contornados, frequentemente foram contratados seguros que indenizariam total ou parcialmente os segurados contra os prejuízos provocados pelas perdas das embarcações ou das cargas trazidas da costa da África para o continente americano.

Tratava-se dos seguros marítimos - que deve ter sofrido seus reveses quando o tráfico foi proibido legalmente a partir de 1831, e, de fato, no ano de 1850 -, mas não da única espécie de seguros negociada pelos membros daquela sociedade escravista estabelecida na província do Rio de Janeiro durante os idos do oitocentos. Se a realidade da escravidão acabou por delinear certos contornos específicos àquela forma de organização social, então, ao aceitar a possibilidade de uns tomarem outros por suas propriedades possibilitava que ela mesma pudesse ser encarada como um negócio e, como tal, sujeito às intervenções do mercado e do direito. De fato, o sujeito livre, dentro da liberdade que lhe concedera a Constituição de 1824, poderia dispor de sua propriedade como bem entendesse, mediante a venda, por exemplo, ou o aluguel do escravo sob condição do pagamento de uma mensalidade ou de uma diária, etc. $\mathrm{O}$ sujeito escravo, enquanto propriedade, portanto, possuía um valor que, assim como outros objetos postos no comércio, sofria as flutuações de um mercado amparado nas leis da oferta e da procura. Em épocas em que a disponibilidade dessa mercadoria atendia a demanda, como foram os 
anos da primeira metade do século XIX, os cativos não seriam ofertados a preços tão elevados como o seriam logo a partir de meados da década de 1850, momentos após a proibição da importação de escravos africanos ao Brasil.

A Lei Eusébio de Queiroz fez extinguir a principal fonte de reprodução daquela sociedade escravista carioca. Muitos dos usos e abusos exercidos sobre a força de trabalho e a vida escrava estiveram estritamente relacionados à facilidade com que esta mercadoria pode ser adquirida no mercado, ou, em outras palavras, à facilidade com que essa mão de obra poderia ser reposta caso fosse perdida pelo trabalho pesado nas plantações agrícolas. A partir da segunda metade do século, época em que foram tomadas muitas medidas visando o fim da escravatura no país, a aquisição, ou esta reposição, torna-se cada vez mais dificultosa, e o cativo passa a ser oferecido a um preço cada vez mais aumentado. A propriedade escrava é valorizada, e os mesmos riscos que outrora já ameaçavam a vida do cativo passaram a ser cada vez mais temidos, pois então uma morte poderia levar consigo boa parte de qualquer fortuna ou cabedal. Não importa o uso que se fizera do escravo, se empregado no trabalho da lavoura ou se obrigado aos ganhos urbanos, o fato é que uma parcela dos senhores, talvez nem tão significativa, contratou com algumas seguradoras a garantia do pagamento de certa quantia em indenização caso lhe sobreviesse a perda de qualquer uma de suas propriedades seguradas.

Tratava-se então dos seguros de vida de escravos, uma modalidade dos seguros terrestres que foi se fazendo cada vez mais presente naquele mercado carioca, desde pelo menos os meados da década de 1840, quando se teve notícia que a companhia de seguros Prosperidade estabeleceu seu escritório na rua de São José no 59. Mas esta seria a única seguradora a contratar sobre os riscos que costumavam acometer a vida dos escravos?

Pergunta de difícil resposta, ao menos logo no primeiro momento após a indagação, posto que as únicas notícias acerca de suas existências haviam sido conhecidas somente das páginas dos manuais jurídicos elaborados para o aprendizado do direito regulamentador dos contratos de seguros, ao que parece sem nenhum comprometimento com uma investigação histórica mais detida sobre este ramo do negócio segurador característico do século XIX. Mesma situação constatada quando da leitura de obras nacionais investigativas da história dos seguros no Brasil durante o oitocentos, como o são as pesquisas coordenadas por Verena Alberti e publicadas em 1998 em um único volume sob o título Entre a solidariedade e o risco: história do seguro privado no Brasil; o artigo de Alexandre Macchione Saes e Thiago Fontelas Rosado Gambi, denominado "A 
Formação das companhias de seguros na economia brasileira (1808-1864)”, de 2009; e o working paper apresentado por Marcelo de Paiva Abreu e Felipe Tâmega Fernandes, "The insurance industry in Brazil: a long-term view”, em 2010, onde relacionam seis delas ${ }^{1}$.

Por outro lado, na literatura estrangeira, três autores norte-americanos dedicaram-se ao tema dos seguros de vida de escravos. O primeiro artigo é fruto de uma pesquisa levada a cabo por Todd L. Savitt, e publicada em 1977-1978 no Journal of Southern History, cujo título é "Slave life insurance in Virginia and North Carolina". O segundo, escrito em coautoria por Cheryl Rhan-Hsin Chen e Gary Simon, denominado "Acturial issues in insurance on slaves in the United States South", e publicado no ano de 2004 pelo Journal of African American History. Nenhum dos dois artigos faz qualquer menção à prática desse negócio segurador no Brasil, a não ser indiretamente, quando descreve alguns aspectos das contratações tomadas pelas companhias estadunidenses quando se disponibilizaram a segurar os proprietários contra os riscos de morte de seus escravos.

Para se conhecer o número de companhias de seguros de vida de escravos que operaram na província do Rio de Janeiro durante o Império, portanto, foi necessário consultar diversas fontes, cada uma delas com possibilidades de conter alguma informação reveladora da existência ou do funcionamento dessas seguradoras, mas ao mesmo tempo com possibilidades de informar a presença de muitas outras companhias de seguros, não necessariamente das que se voltaram exclusivamente à garantia da vida dos escravos. A investigação avançava, e à medida que fomos nos deparando com dados referentes a qualquer companhia de seguros presente no mercado carioca do século XIX, todos eles foram sendo organizados num quadro que, ao final, acaba por relacionar a totalidade das empresas atuantes no ramo segurador daquela praça comercial. Dessa forma, as companhias seguradoras de vida de escravos puderam ser apresentadas sob os momentos de maior ou menor concentração do mercado de seguros como um todo, ao mesmo tempo em que puderam ser destacadas as épocas mais propícias para o florescimento desta modalidade em especial: afora a Prosperidade, surgida em 1845, o restante das seguradoras pediram autorização para funcionar nos idos da década de 1850 e da década de 1870. Mas, como dito, todas essas informações foram conhecidas em meio às informações

\footnotetext{
${ }^{1}$ Cf. ALBERTI, Verena (Coord.), Entre a solidariedade e o risco, "Introdução", p. 13, 16; SAES, Alexandre Macchione; GAMBI, Thiago Fontelas Rosado, A Formação das companhias de seguros na economia brasileira (1808-1864), p. 15-16; ABREU, Marcelo de Paiva; FERNANDES, Felipe Tâmega, The insurance industry in Brazil, p. 6, nota 17.
} 
que noticiaram a presença do maior número possível de companhias de seguros naquele mercado.

O Quadro Companhias de Seguros em funcionamento na Província do Rio de Janeiro $(1808-1889)^{2}$ foi elaborado para que servisse às análises que dessem conta de caracterizar, ao menos em parte, o mercado segurador que funcionou na província do Rio de Janeiro nesse período em que transcorreu quase todo o século XIX. Um mercado que esteve presente enquanto a Corte portuguesa esteve aí instalada, e também quando partiu em retorno à península europeia legando à sua antiga colônia americana a fundação de um Império independente (1822-1889). Muito embora não possamos afirmar que conseguimos coletar exaustivamente todos os dados que bem mereceriam compor esse esforço, cujas lacunas bem como eventuais equívocos decorrem da grande quantidade de informações a serem levantadas a partir de outra grande quantidade de fontes; apesar disso seu conteúdo representa uma tentativa razoável de identificar o maior número de companhias seguradoras que, por um breve período que seja, negociaram suas apólices na capitania que abrigou a capital do Reino, primeiro, e, posteriormente, na província que se prestou à sede do governo do Império do Brasil durante toda sua vida política.

Além do mapeamento das sociedades que acabaram por cooperar, de algum modo, para a dinâmica dessa economia capitalista do oitocentos, o Quadro que ora apresentamos oferece, para cada companhia de seguros, a primeira data sobre a qual tomamos conhecimento de sua existência, e também a data da última notícia que obtivemos acerca de seu funcionamento no negócio. Pensamos que se assim procedêssemos, as chances de nos enganarmos quanto ao real volume desse mercado segurador seriam, talvez, menores. E isso porque, uma vez conhecidos os períodos de vida de todas as companhias, poderíamos facilmente compará-los e constatar quantas delas, em uma dada época, de fato chegaram a coexistir. Mas, nem todas as companhias seguradoras puderam ser objeto de avaliação comparativa, pois, para citar apenas alguns exemplos, as Companhias de Seguros Probidade (1817), Restauradora (1820), Segurança (1820) e Retribuição $(1820)^{3}$, só as localizamos em apenas uma fonte, que nos forneceu notícia somente de uma única data. Outras empresas como a Companhia de Seguros Mútuos sobre a vida Tutora Brasileira $(1858)^{4}$, a Companhia de Seguros Apollo (1874) ${ }^{5}$, ou as

\footnotetext{
${ }^{2}$ Cf. Anexo 2, p. 195.

3 Cf. BOHRER, Saulo Santiago, “Interesses Seguros”, p. 56. As Companhias de Seguro Probidade, Restauradora, Segurança e Retribuição compõem a "Tabela 6 - Relação das Companhias de Seguro entre 1810 e 1831 ".

${ }^{4}$ Cf. Decreto n. 2.299, de 06 de novembro de 1858.
} 
estrangeiras Union Marine Insurance Company Limited $(1872)^{6}$ e Norwich Union Fire Insurance Society $(1874)^{7}$, por mais que estivessem presentes em uma variedade maior de obras consultadas, todas elas nos indicaram somente uma, e a mesma, data ${ }^{8}$.

As companhias seguradoras listadas em nossa relação também foram identificadas pelo local de suas sedes. Quando nacionais, sempre que possível, as províncias de origem de cada uma delas foram reveladas; quando estrangeiras, na maioria das vezes vão divulgadas algumas localidades que nos permitiram determiná-las, podendo ser o nome da cidade ou o do país em que bem poderiam estar registradas. O conhecimento desses detalhes geográficos, digamos, em alguns momentos nos auxiliou na resolução de poucos casos em que emergiram dúvidas quanto á identidade de certas companhias, uma vez que versavam sobre seguradoras homônimas ou que se denominavam com nomes semelhantes. De igual modo, foram úteis as informações que levantamos acerca dos riscos segurados por cada uma delas. Com posse dessas informações pudemos julgar, por exemplo, que a Companhia Transatlântica de Seguros contra o fogo, ora referida como Sociedade Transatlântica de Seguros contra o fogo ${ }^{9}$, na verdade corresponderam à mesma seguradora.

Ambas são de Hamburgo (Alemanha) e ambas atuam somente no ramo dos seguros terrestres (indenizam os segurados no que tange às suas perdas ocasionadas por incêndios). Embora os qualificativos 'Companhia' e 'Sociedade' muito bem poderiam ser um indicativo de que estaríamos diante de empresas distintas, José Ferreira Borges, jurisconsulto português que se dedicou ao estudo do direito mercantil, chama-nos a atenção para a sinonímia dos termos em meados do século XIX:

Companhia, termo jurídico-comercial: antigamente, e civilmente falando é sinônimo de sociedade (...). Ainda que hoje se possa dizer companhia por sociedade, todavia, estritamente falando, companhia é a associação incorporada por carta ou alvará de instituição concedida pelo Governo ${ }^{10}$.

\footnotetext{
${ }^{5}$ Cf. Decreto n. 5.729, de 27 de agosto de 1874.

${ }^{6}$ Cf. Decreto n. 5.083, de 11 de setembro de 1872.

${ }^{7}$ Cf. Decreto n. 5.711, de 12 de agosto de 1874.

8 Acerca de todas as quatro Companhias de Seguro (Tutora Brasileira, Apollo, Union Marine e Norwich Union) obtivemos informações na Coleção das Leis do Império e na relação das Sociedades Mercantis autorizadas a funcionar no Brasil (1808-1946). Porém, a Tutora Brasileira ainda constava dos aditamentos providenciados por Cândido Mendes de Almeida ao Primeiro Tratado dos Princípios de Direito Mercantil e Leis de Marinha, de José da Silva Lisboa, o Visconde de Cairu; a companhia Apollo, por sua vez, teve uma chamada na publicação do Almanak Laemmert de 1875.

${ }^{9}$ Cf. Decreto n. 5.242, de 29 de março de 1873.

${ }^{10}$ Cf. BORGES, José Ferreira, Diccionario Juridico-Commercial, p. 91 . Ver entrada "Companhia”.
} 
Por outro lado, outra seguradora, a Companhia Transatlântica de Seguros Marítimos e Terrestres ${ }^{11}$ não compartilha dos mesmos padrões da primeira. Pelo contrário, apesar de se apresentarem sob o mesmo nome, esta última segura riscos tanto em mar como em terra e, muito embora a localização geográfica de sua sede também seja a Alemanha, é da cidade de Berlim.

Se o conhecimento do local onde as companhias mantinham suas respectivas sedes pode nos ajudar em alguns casos em que a semelhança das denominações de seguradoras fez emergir pequenas confusões quanto às suas identidades, convém relembrar que somente constaram da listagem as seguradoras que, pelo que nos disseram as fontes consultadas, chegaram a tomar riscos, ou ao menos o pretenderam, na província do Rio de Janeiro. Contudo, o fato de que as companhias identificadas ali se estabeleceram, ou ao menos assim o pretenderam, não pode querer significar que eram somente elas que seguravam os negociantes do Rio de Janeiro. Ao que tudo indica, era provável que esses negociantes tinham a opção de contratar seguros para os riscos inerentes às suas atividades com companhias de outras praças, sejam elas brasileiras ou estrangeiras. E se estrangeiras, não necessariamente com as que chegaram a armar suas agências na cidade ou região.

Por outro lado, e concomitantemente a tudo isso, negociantes de outras praças poderiam também contratar com as companhias de seguros da capital do Império. Essa liberdade de contratação que cogitamos parecia não ser nenhuma novidade, mas também não necessariamente algo vantajoso ao negócio, pelo menos no início da década de 1820 , dentre os negociantes portugueses. Os negociantes da praça do Porto, em especial, "logo nas suas primeiras representações às Cortes liberais, [reivindicaram] o direito de constituírem seguradoras para nelas garantirem os objetos indispensáveis aos seus interesses econômicos"12, pois, uma vez que à praça de Lisboa fora concedida a exclusividade para se contratar seguros, os portuenses eram "obrigados a mandar fazer os Seguros dos nossos [seus] cabedais a Lisboa - ao Brasil - ou às Nações Estrangeiras." "13 Se isso era um estorvo, diziam, era porque tinham mais gastos com comissões e impostos;

\footnotetext{
${ }^{11}$ Cf. Decreto n. 5.283, de 19 de maio de 1873.

${ }^{12} \mathrm{Cf}$. ALVES, Jorge Fernandes, A Difusão da técnica atuarial e as primeiras companhias de seguros no Porto (século XIX), p. 193.

${ }^{13}$ Cf. ALVES, Jorge Fernandes, op. cit., p. 194. A citação é um trecho de uma das representações dos negociantes do Porto às Cortes Liberais transcrita pelo autor (Jorge Fernandes Alves). Ela compõe o opúsculo Resultado dos Trabalhos da Comissão do Comércio da Praça do Porto, criada por ordem das Cortes Constituintes de 28 d'Agosto de 1821, acerca dos estorvos que dificultam o mesmo Comércio e de diversos objetos sobre que foi consultada.
} 
porque a notícia da perda do objeto segurado poderia chegar antes do aviso formal; e, por fim, porque o seguro era um negócio que muito enriquecia qualquer praça comercial.

A identificação das companhias que, pelo que constatamos, compuseram o mercado segurador do Rio de Janeiro no século XIX; o período em que provavelmente exerceram suas atividades; os locais em que foram estabelecidas; e os riscos por ela segurados, são apenas algumas das informações dentre tantas outras que as fontes consultadas podem nos fornecer. Além dos dados que vão organizados no quadro que ora apresentamos, outros poderiam interessar a pesquisas que por ventura se proponham adentrar com maior profundidade nesse ramo do comércio, ou mesmo nas atividades econômicas que se praticavam no Rio de Janeiro do século XIX.

De fato, tomar conhecimento do montante do capital social levantado para o início das atividades, e também da quantidade e do valor das ações distribuídas entre os acionistas; da estrutura da companhia, compreendendo o número de diretores ou caixas, suas funções no quadro diretivo da empresa, bem como suas responsabilidades e remunerações; além de seus nomes e dos agentes que chegaram a representar os negócios de seguradoras estrangeiras na província; tudo isso poderia contribuir para análises que se propusessem a medir, se assim podemos dizer, o tamanho desse mercado frente a outros ramos de comércio; a averiguar a estrutura jurídica das companhias, bem como as restrições impostas às suas atividades; ou, ainda, poderia contribuir para trançar a teia de relações na qual estiveram envolvidos capitalistas e negociantes que, ao mesmo tempo em que ocupavam cargos diretivos das companhias de seguros, também ocupavam cargos diretivos de bancos ou de companhias destinadas á outras atividades econômicas, ou cargos administrativos em alguns órgãos do Estado.

Todos esses dados foram extraídos de duas fontes em essencial. Foram elas, basicamente, que nos proporcionaram o levantamento das informações concernentes à identificação das companhias de seguros e de algumas de suas características de funcionamento, sendo que as demais fontes consultadas acabaram por nos auxiliar apenas na confrontação e posterior confirmação do que fora apurado; raras foram as vezes em que estas outras nos brindaram com informações novas.

A que primeiro se averiguou é uma fonte oficial, cujo propósito foi dar publicidade aos atos do Poder Legislativo e do Poder Executivo, praticados durante o período em que o Brasil ainda era a colônia portuguesa do continente americano, depois elevado à categoria de Reino Unido (1808-1822) - que compreendeu os anos do governo lusitano de D. João 
VI, e também o Primeiro Reinado de seu filho, D. Pedro I -; e durante todo o período de independência política do Império do Brasil.

A Coleção das Leis do Império do Brasil (1808-1889) - disponibilizada no site da Câmara dos Deputados em meio eletrônico ${ }^{14}$ - relaciona todos os Decretos, Alvarás, Cartas Régias, Decisões Imperiais, Cartas de Leis e Leis, e serviu de matéria-prima a uma primeira tentativa de aproximação com os documentos referentes às companhias de seguros que se arriscavam a garantir as perdas dadas em mar ou em terra, mas especialmente às companhias de seguros de vida de escravos. Todo o índice da Coleção, um a um dos cerca de oitenta anos, foi averiguado e à medida que algumas normas nos interessavam, mesmo que aparentemente, eram desde então selecionadas e passariam a compor um quadro preliminar que desse conta de organizá-las ainda que temporariamente.

Essas normas destacadas da Coleção tanto nos remetem à regulação das atividades das companhias de seguros, por exemplo nas suas relações mantidas com o Estado, como também nos noticiavam as autorizações concedidas pelo Governo para que se incorporassem e levassem a cabo a contratação de seus negócios. Normalmente essas permissões concedidas pelo poder oficial traziam consigo os Estatutos que pautariam o comportamento das seguradoras no mercado. Esses Estatutos, como parece, eram primeiramente sugeridos ao Governo por algum, ou mais de um, dos negociantes envolvidos no empreendimento. Mas, como corriqueiramente acontecia, se fosse o caso do Governo não concordar com algumas das disposições apresentadas, os Decretos condicionavam a incorporação dessas companhias à observância das alterações que ele mesmo trazia, normalmente antes dos Estatutos anexados. Para o início do período, de igual modo, pudemos constatar que as primeiras companhias de seguros, além da necessária autorização do Príncipe Regente para que pudessem funcionar, deveriam obedecer a certas disposições. Porém, essas seguradoras, estabelecidas na capitania da Bahia logo da chegada de D. João, em 1808 - Companhia de Seguros Boa Fé ${ }^{15}$ e Companhia de Seguros Conceito Público ${ }^{16}$-, e a que se estabeleceu na cidade do Rio de Janeiro dois anos depois, a Companhia de Seguros Indemnidade ${ }^{17}$, deveriam se comportar no mercado mediante a observância das Condições aprovadas juntamente com a

\footnotetext{
${ }^{14}$ Cf. endereço eletrônico:

http://www2.camara.gov.br/atividade-legislativa/legislacao/publicacoes/doimperio.

${ }^{15} \mathrm{Cf}$. Decreto de 24 de fevereiro de 1808.

${ }^{16}$ Cf. Carta Régia de 24 de outubro de 1808.

${ }^{17}$ Cf. Resolução de Consulta da Real Junta do Comércio, Agricultura, Fábricas e Navegação de 5 de fevereiro de 1810 (Resolução $\left.n^{\circ} 05\right)$.
} 
autorização para seus respectivos funcionamentos ${ }^{18}$. Somente nos deparamos com o termo Estatutos a partir do Decreto que autorizou a fundação, no Rio de Janeiro, da Sociedade de Seguros Mútuos Brasileiros, no dia 29 de abril de 1828.

Percebemos vantagens e desvantagens quando nos propomos abordar a Coleção das Leis do Império do Brasil (1808-1889) tendo em vista os propósitos da pesquisa. Em termos positivos, ela está uma fonte acessível, principalmente para um trabalho razoavelmente demorado como o é o de leitura, identificação e organização dos dados coletados. E também representa uma fonte importante caso o propósito seja a identificação de companhias de seguros - mas também de companhias que atuavam em outros ramos do mercado, como na construção de estradas de ferro (principalmente a partir da década de 1860), ou no transporte terrestre ou via navegação marítima e fluvial - e, uma vez localizados, os Decretos, e especialmente os Estatutos, quase sempre trouxeram informações que revelaram, à sua maneira, o modo como se organizavam e as características de seus negócios.

Por outro lado, os dados provenientes exclusivamente da legislação não nos permitiriam montar um quadro cujo propósito fosse transmitir alguma informação mais completa acerca do mercado segurador instalado no Rio de Janeiro Imperial. Várias lacunas se tornariam evidentes, e somente conseguiríamos remediá-las mediante a complementação e confrontação com as informações encontradas em outras fontes. De fato, somente com os Decretos em mãos não nos seria possível saber se as companhias autorizadas a funcionar realmente chegaram a ser incorporadas. Ou, se foram incorporadas, ainda assim desconheceríamos uma data a mais próxima deste feito. Ao que parece, na maioria das vezes as autorizações repercutiam mesmo na incorporação das seguradoras. Mas, mesmo que contássemos com uma porcentagem elevada de incorporações em relação às autorizações concedidas, ainda assim nos depararíamos com alguns obstáculos colocados pelas informações reveladas pelos Decretos. Ou, caso queira, pelas informações não reveladas.

É que nas ocasiões em que as companhias foram incorporadas, poderia ocorrer de algumas delas não contratarem imediatamente sobre todos os riscos que seus Estatutos

\footnotetext{
${ }^{18}$ As companhias de seguros Boa Fé e Conceito Público não compõem o Quadro das Companhias de Seguros em funcionamento na Província do Rio de Janeiro (1808-1889) justamente por estarem sediadas na capitania da Bahia, e por não dispormos de qualquer notícia que nos afirme terem elas estabelecido agências no Rio de Janeiro. A Carta Régia de 24 de outubro de 1808, que aprovou a fundação da Conceito Público, trata-se na realidade de uma ratificação de D. João a um ato anteriormente praticado pelo Conde da Ponte, Governador e Capitão General da Bahia.
} 
recém aprovados lhes permitiam contratar. E, tomando-se unicamente a legislação como fonte de informações, não nos seria possível conhecer, para alguns casos, a época em que as seguradoras passaram a negociar sobre esses riscos, ou mesmo se de fato chegaram a negociá-los. Já no que diz respeito ao período em que as companhias de seguros chegaram a atuar no mercado, por seu turno, o fato de termos encontrado mais de um Decreto correspondente a uma mesma seguradora - pois não eram raras as vezes que o Governo considerava as petições das companhias que vinham pedir a reforma de seus Estatutos não quer dizer que o período compreendido entre uma data e outra foi aquele em que elas realmente estiveram em funcionamento. Ainda que duas ou mais datas nos informassem certo período de tempo em que provavelmente as companhias podem ter de fato funcionado, contudo, isso não quer dizer que as seguradoras já não funcionassem antes de ser autorizadas pelo Governo, e portanto a data do primeiro Decreto encontrado não poderia servir ao início de suas atividades; e, por outro lado, como era mais frequente, não quer dizer que a data do último Decreto localizado configurasse realmente o termo final das atividades de uma dada companhia no mercado, a não ser que se tratasse da cassação da autorização do seu funcionamento ${ }^{19}$.

A segunda fonte consultada, e que deu conta de preencher muitas dessas lacunas, foram os volumes do Almanak administrativo, mercantil e industrial do Rio de Janeiro Almanak Laemmert, que veio a lume no ano de 1844, e foi averiguado até o seu quadragésimo sexto número, publicado em 1889. Ao que tudo indica, o periódico acabou sendo bastante utilizado por profissionais liberais e por pessoas envolvidas no comércio carioca do século XIX. Logo no primeiro volume ofertado aos habitantes do Rio de

\footnotetext{
${ }^{19}$ Pudemos constatar poucos casos em que o poder oficial cassa a autorização de funcionamento de uma companhia seguradora. Tal aconteceu com a Companhia de Seguros Esperança, sediada na província do Rio Grande do Sul. Autorizada a sua organização e aprovados seus Estatutos pelo Decreto no 2.273 , de 9 de outubro de 1858, foi cassada a autorização e dissolvida pelo Decreto $\mathrm{n}^{\circ} 3.744$, de 28 de novembro de 1866 por desobediência aos mesmos Estatutos, sendo que tempos antes, em 3 de março de 1860, fora intimada pelo Aviso $\mathrm{n}^{\circ} 106$ para que cessasse de "empregar seus fundos em operações bancais", sob pena de ser cassada; um segundo caso de cassação, o da Companhia de Seguros Mútuos sobre a vida e contra o fogo Mutualidade (Associação Brasileira Mutualidade), também fora ocasionado porque os negócios da companhia estavam sendo "geridos de modo prejudicial aos interesses dos associados, e contrário não só às condições e preceitos dos próprios estatutos, mas também às disposições da Lei n. 1083 de 22 de Agosto de 1860 e Decreto n. 1711 de 19 de Dezembro do dito ano", cf. Decreto n 8.446, de 8 de março de 1882 . A Mutualidade havia sido autorizada a funcionar, com a respectiva aprovação dos estatutos, dez anos antes, pelo Decreto $\mathrm{n}^{\mathrm{o}}$ 4.987, de 19 de junho de 1872; em 1878, outro caso: a Companhia Lotérica de Seguros autorizada a funcionar pelo Decreto $\mathrm{n}^{\circ} 5.628$, de 9 de maio de 1874, foi cassada porque se entendeu que segurava risco algum. $\mathrm{O}$ "imposto a que estão sujeitos os prêmios da loteria é uma obrigação legal, que não está sujeita às contingências, que constituem risco para ser garantido por contrato de seguro", cf. Decreto $\mathrm{n}^{\circ}$ 6.972, de 20 de julho de 1878; por fim, também em 1878, a Companhia Garantia dos Proprietários, autorizada sua incorporação pelo Decreto $\mathrm{n}^{\circ} 5.789$ de 11 de novembro de 1874 , fora cassada em atendimento a alguns de seus acionistas, cf. Decreto ${ }^{\circ}$ 6.968, de 13 de julho de 1878.
} 
Janeiro, os editores chamaram a atenção do público leitor para a utilidade da obra. Diziam eles que o Almanak seria indispensável àqueles que motivados pela profissão, por exemplo, seriam obrigados a frequentar regularmente tanto estabelecimentos públicos (Tribunais, Câmara Municipal, etc.) como particulares (bancos, lojas, casas comerciais, etc.), as repartições, sejam elas civis, eclesiásticas, ou militares, ou teriam de tratar com empregados públicos (Procuradores, Magistrados, etc.) ou outros profissionais e negociantes; em geral, a obra seria útil também a todos os que desejassem encontrar quaisquer informações sem que para isso fosse obrigado a perder seu tempo com perguntas indicativas de lugares, de nomes, etc.; e, por último, diziam, o Almanak poderia muito bem funcionar como um guia para aqueles provincianos, quando necessitassem de visitar a capital para tratarem de seus negócios ${ }^{20}$.

Algum tempo passado, em 1872, depois de 29 volumes já terem sido publicados, a obra ganha uma nova utilidade, segundo os editores, principalmente àquele "observador atento e ao estatístico curioso", pois a riqueza de dados referentes à corte, à cidade, aos habitantes, à indústria, ao comércio, enfim, já poderiam ser percebidos comparativamente aos anos anteriores ${ }^{21}$. E esses dados traziam informações coletadas além das fronteiras da capital do Império. Se o volume publicado em 1848 já agregara as notícias da "maior parte dos 27 Municípios da Província do Rio de Janeiro,"22, em 1875 todos eles, e também a grande maioria de suas freguesias, estiveram relacionados ${ }^{23}$.

Todas essas notícias da capital e do interior da província, constantes de todos os volumes do Almanak Laemmert (1844-1889), foram coletados e organizados, ano a ano, numa tabela que acusasse somente os nomes das companhias de seguros que ali foram se estabelecendo, os nomes que compuseram seus quadros diretivos e administrativos, e os endereços em que estiveram localizados seus escritórios ${ }^{24}$. Contudo, por mais que esta fonte tenha nos brindado com uma grande quantidade de informações a respeito das movimentações conhecidas por aquela praça mercantil, é cedo para afirmar que todos esses dados cuidadosamente publicados, de fato, espelharam a realidade vivida pelo comércio do

${ }^{20}$ Cf. Almanak administrativo, mercantil e industrial do Rio de Janeiro - Almanak Laemmert, 1844, "Advertência dos Editores", p. III-IV.

${ }^{21}$ Op. cit., 1872, "Prólogo", p. VII.

22 Op. cit., 1848, "Advertência", p. VI.

${ }^{23}$ Op. cit., 1875, "A Quem Ler", p. VII.

${ }^{24}$ Cf. Anexo 4, p. 225. O quadro organizado deu conta de relacionar todas as seguradoras anunciadas nas páginas do Almanak. As que foram inseridas no Anexo 4 foram aquelas que negociaram os seguros de vida de escravos, seja exclusivamente, ou paralelamente contra riscos marítimos, ou terrestres. 
Rio de Janeiro durante boa parte da vida política do Império. E isso, talvez, pela própria natureza do Almanak.

Antes de mais nada, as "Advertências dos editores", as "Advertências" simplesmente, os "Prólogo", os "Ao Leitor", os "Prefácio", enfim, que abriam cada edição do Almanak Laemmert, denunciavam as dificuldades e as soluções encontradas pelos editores para dar conta de realizar, com sucesso, o empreendimento. Embora a obra fora de grande utilidade aos negócios dos coevos, ela própria fora um negócio. Os editores remetiam questionários para a capital, bem como para outras cidades da província, em busca das informações necessárias para comporem as chamadas dos órgãos oficiais, das casas comerciais, dos bancos, de outras companhias ou sociedades mercantis, etc.; mas também estiveram dispostos a receber os pedidos dos interessados em anunciar suas empresas nas páginas do Almanak, de modo a veicular mais informações além das que a casa editorial se prontificava a publicar (no caso das companhias de seguros, elas não pagariam nada pela inclusão de seus respectivos nomes, quadro de pessoal, e endereço).

No entanto, invariavelmente os editores reclamavam da incompreensão das pessoas para com um empreendimento por si só muito complexo, porque lidava com grande quantidade de dados a organizar. Muitos não respondiam aos questionários, outros tantos compravam a obra a cada dois anos, o governo teimava em não adotar o periódico nas repartições, outros não atualizavam os dados ou, quando o faziam, já não a tempo de serem publicados no próximo número (os volumes eram publicados logo no início de cada ano). Como se vê, todos esses empecilhos acabam por dificultar um conhecimento exato da conformação anual daquele mercado, mas apesar de todas essas transformações, ou mesmo contando com todas as imperfeições, lacunas, e também com todos os erros cometidos pelos realizadores do Almanak, de algum modo aquela realidade, e os atores que foram lhe dando forma, puderam ser percebidos.

Assim como sugeriram os editores "ao observador atento e ao estatístico curioso", a consulta a todos os 46 volumes publicados, de fato, permitiu que fossem traçados alguns contornos do mercado segurador estabelecido na província do Rio de Janeiro. Puderam ser conhecidos, por exemplo, os nomes das pessoas que ano a ano dirigiram ou foram empregadas pelas seguradoras; a primeira data em que foram chamadas, e também o ano que deixaram de o ser; se as companhias optaram por inserir um anúncio ou propaganda, mais informações referentes aos seus negócios, e ao seu mercado, foram reveladas; muitas vezes fizeram ser conhecido seu capital realizado, e/ou o capital segurado; seus endereços, 
etc. Ao que parece, o periódico acabou funcionando mesmo como uma vitrine onde as companhias, não só seguradoras, poderiam expor ou chamar o público a procurarem pelos seus serviços. E talvez motivadas pela concorrência, muitas delas teriam se interessado em propagandear suas atividades naquelas páginas, tanto as que obtiveram autorização do governo imperial para poderem funcionar, como as que contrataram suas apólices livremente. Quando as companhias de seguros levantadas do periódico foram confrontadas com as que coletamos das fontes legislativas, estas seguradoras puderam ser notadas. Foram os casos das companhias de seguros marítimos de Paris, Hàvre, Antuérpia, Marseille, Bremen, Bordeaux, da Sociedade la Ausiliadora, e da Agência dos seguradores de Hamburgo.

Uma vez conhecida, a relação contendo todas as seguradoras apuradas até aquele momento foi comparada com a relação publicada por outras obras que de igual modo se ocuparam de um levantamento legislativo, ou da identificação das companhias, sejam elas as de seguros ou as que também se dedicaram a outras atividades mercantis. São os casos de duas obras ofertadas pelo Instituto de Resseguros do Brasil, Coletânea da legislação brasileira de seguros (De 29 de abril de 1828 a 1 de abril de 1947) (1949), e o Ementário da legislação brasileira de seguros (1808 a 1973) (s. d.); ou a que foi organizada pelo Ministério do Trabalho, Indústria e Comércio, em 1947: Sociedades Mercantis autorizadas a funcionar no Brasil (1808-1946). Esta última listagem também serviu de matéria-prima a outras pesquisas, como as de Ana Célia Castro, As Empresas estrangeiras no Brasil: 18601913 (1976), e de Joely Aparecida Ungaretti Pinheiro, Empresas alemãs no Estado de São Paulo: 1873-1940 (2001) ${ }^{25}$. No entanto, ao ser confrontada com os dados que levantamos preliminarmente, percebemos que a lista providenciada pelo Ministério apresentava algumas lacunas, pelo menos no que dizia respeito às companhias de seguros.

As comparações seguiram, porém, com fontes que porventura denunciassem a participação de seguradoras nas consultas remetidas ao Conselho de Estado, ou nos processos judiciais surgidos a partir de dúvidas ou desentendimentos entre as partes contratantes: seguradores e segurados. Nesse sentido, se uma companhia aparecesse na discussão de algum parecer de determinadas seções do Conselho, ou se se configurasse num dos pólos de qualquer ação intentada ao Poder Judiciário, todas essas participações bem poderiam revelar datas indicativas da sua existência, do seu funcionamento. Por tudo isso, não cessaram as comparações da relação inicial e logo a confrontamos com as

${ }^{25}$ As autoras utilizaram-se igualmente de outros documentos para a realização de suas pesquisas. Para maiores detalhes bibliográficos, confira as Referências desta dissertação. 
informações constantes dos 13 volumes das Imperiaes Resoluções do Conselho de Estado na Seção de Fazenda (1842-1889), organizadas a mando do Governo entre 1867 e 1890; e com os 2 volumes das Imperiaes resoluções tomadas sobre consultas da secção de justiça do conselho de estado (1884), compiladas por José Próspero Jeová da Silva Caroatá ${ }^{26}$. E, para o caso das decisões judiciais, com os 3 volumes da Jurisprudencia dos Tribunaes (1868), de Manoel da Silva Mafra ${ }^{27}$; com a obra Jurisprudencia Commercial (1870), de Francisco Batista Marques Pinheiro ${ }^{28}$; com os 50 primeiros volumes de O Direito: revista de legislação, doutrina e jurisprudência (1873-1889) ${ }^{29}$; e, por último, com os processos catalogados pelo Acervo Judiciário do Arquivo Nacional do Rio de Janeiro ${ }^{30}$.

Só depois de empreendermos todas essas comparações, e também às informações constantes das obras especializadas, é que encerramos a composição do Quadro Companhias de Seguros em funcionamento na Província do Rio de Janeiro (1808-1889). Ele serviu às análises e à elaboração dos gráficos e tabelas que ilustraram os capítulos

${ }^{26}$ José Próspero Jeová da Silva Caroatá é natural da província de Alagoas, e nasceu no dia 25 de abril de 1825. Formou-se em Direito pela Faculdade de Recife, em 1850; foi advogado, e depois nomeado para o cargo de $2^{\circ}$ Oficial da Secretaria da Justiça. Morreu no Rio de Janeiro, em 1890, legando a publicação de várias obras especializadas na literatura jurídica, dentre as quais, Vademecum forense (1866); Repertório do crime (1875); além das Imperiaes resoluções tomadas sobre consultas da secção de justiça do conselho de estado (1884). Cf. BLAKE, Augusto Victorino Alves Sacramento, Diccionário Bibliographico Brasileiro, vol. 5, p. 143-145.

${ }^{27}$ Manoel da Silva Mafra nasceu no dia 12 de outubro de 1831, em Santa Catarina, e formou-se em Direito pala Faculdade de São Paulo. Retornando à sua província natal, chegou a ser eleito Deputado Provincial, e a ocupar o cargo de Diretor da Instrução Pública. Além de ter sido advogado, foi nomeado Juiz de Direito (Pernambuco, Paraná, Minas Gerais e Niterói); Chefe de Polícia (Paraná); Presidente da Província do Espírito Santo; e Ministro da Justiça (1882). Foi eleito Deputado à Assembleia Geral representando a província de Santa Catarina (1881-1884, 1885). Foi autor de diversas obras, além de Jurisprudencia dos Tribunaes (1868), publicou, dentre outras, Novo Formulario dos termos dos processos, de inquérito policial, de formação de culpa e julgamento perante o Jury (...) (1871); e Repertorio ou Índice Alphabetico da lei de alistamento militar, annotado (1875). Cf. BLAKE, Augusto Victorino Alves Sacramento, op. cit., vol. 6, p. 198-200.

${ }^{28}$ Francisco Batista Marques Pinheiro é português nascido na Vila de Mirandela (comarca de Bragança), no dia 4 de setembro de 1841. Ainda jovem mudou-se para o Brasil, e bacharelou-se em Direito pela Faculdade de São Paulo, em 1865. Foi advogado no foro do Rio de Janeiro. Além de Jurisprudencia Commercial escreveu, dentre outras obras, Apontamentos sobre pontos diferenciaes entre a constituição do Brazil e a carta constitucional do reino de Portugal (1864). Cf. BLAKE, Augusto Victorino Alves Sacramento, op. cit., vol. 2, p. 405-406.

${ }^{29}$ A revista $O$ Direito, que foi propriedade do advogado João José do Monte Júnior, foi publicada sob um modelo semelhante ao que atualmente é conhecido pelos periódicos jurídicos. A coleção completa da revista é composta por 120 volumes, publicados entre 1873 e 1913. Paulo Macedo Garcia Neto analisou todos os 50 volumes publicados durante os anos de 1873 e 1889, e pode contar 933 acórdãos de revistas julgados no período 1871-1889, cf. GARCIA NETO, Paulo Macedo, O Judiciário no crepúsculo do Império (1871-1889), p. 108-111; LOPES, José Reinaldo de Lima, O Supremo Tribunal de Justiça no apogeu do Império (18401871), p. 75. Na contagem que empreendemos, pudemos constatar que do total dessas revistas, 46 trataram do tema dos seguros (27 referiram-se aos seguros marítimos; e outras 19 resolveram questões concernentes aos seguros terrestres). A obra de Francisco Batista Marques Pinheiro, Jurisprudencia Commercial, trouxe publicadas 09 decisões, e Manoel da Silva Mafra no seu repertório de Jurispudencia dos Tribunaes, um pouco menos, 06 .

${ }^{30}$ Cf. www.arquivonacional.gov.br. 
intermediário e final desta dissertação, e acabaram por dar algum tom a uma pesquisa que é eminentemente um trabalho exploratório.

O primeiro capítulo, ao mesmo tempo em que tenta localizar a contribuição dos seguros marítimos para o sucesso dos empreendimentos capitalistas em geral, e particularmente para o comércio transatlântico de escravos, chama a atenção para as dificuldades que porventura enfrentaram os seguradores numa época em que os britânicos desejaram a ferro e fogo o fim do tráfico negreiro. Os seguros contratados para a garantia de eventuais perdas de cativos quando da travessia do Atlântico acabou por sofrer as inconstâncias das perseguições, dos aprisionamentos e dos afundamentos de que foram alvo inúmeras embarcações negreiras durante a primeira metade do século XIX, principalmente a partir da década de 1830. O negócio acessório, os seguros, de algum modo acompanhou a sorte do principal, o empreendimento negreiro. Contudo, apesar da estreita relação mantida entre o negócio segurador e o tráfico transatlântico, a Lei Eusébio de Queiroz, promulgada em 1850, parece não ter afetado todos os usos que aquela sociedade escravista estabelecida na província do Rio de Janeiro poderia fazer dos seguros. Nesse sentido é que o capítulo, ao seu final, aponta para a presença de seguradoras dedicadas a garantir o pagamento de certa quantia em indenização àquele senhor segurado contra a perda de qualquer propriedade escrava. Nesses casos, a contratação corria sobre riscos classificados no ramo dos seguros terrestres, que de igual modo estiveram presentes na realidade da escravidão.

O capítulo seguinte, por sua vez, colabora para a construção de uma imagem, ainda que incompleta e imperfeita, do mercado segurador estabelecido naquela praça comercial. Gráficos e tabelas nos auxiliaram a organizar muitos dos dados relacionados no Quadro Companhias de Seguros em funcionamento na Província do Rio de Janeiro (1808-1889), bem como apresentá-los sob mútua comparação. Eles desenham traços e linhas representativas dos números correspondentes às companhias estrangeiras e nacionais; seguradoras de riscos terrestres, marítimos ou de ambos, enfim. Porém retratam o resultado alcançado com todo o trabalho de pesquisa, coleta e organização dos dados oferecidos pelas fontes mencionadas anteriormente. Por essa razão, números e resultados preliminares, inacabados, e que ainda comportam outras tantas revisões. De todo modo, ainda que devedor de um retrato fidedigno do mercado carioca, este segundo capítulo 
acaba por revelar as épocas que presenciaram maiores e menores movimentos neste ramo do comércio, o ramo segurador.

O terceiro capítulo, por fim, reconhece a vida do escravo como um bem tão passível de ser segurado como o foram as construções contra a destruição ou os danos provocados por incêndio, por exemplo; ou as mercadorias quando transportadas por vias terrestres; ou as áreas agricultadas contra os riscos de chuva forte, seca ou geada; ou mesmo a vida de pessoas livres que, por sinal, alimentou discussões no círculo jurídico, ao que parece, durante quase todo o século XIX. As seguradoras de vida de escravos foram apresentadas primeiramente em comparação aos dados encontrados para o mercado como um todo, analisados no capítulo precedente: num universo de 143 seguradoras apuradas - somadas as nacionais e as estrangeiras, seguradoras de todos os riscos (marítimos e terrestres) -, 11 companhias obtiveram autorização do governo imperial para serem incorporadas, ou funcionaram, de fato, a partir de meados da década de 1840 até o último suspiro da escravidão no Império. No momento seguinte, tais companhias foram apresentadas por seus negócios, especificamente pelas regras contidas em seus Estatutos, que subordinavam sua estrutura, organização, e sua atuação no mercado. Sempre que percebidas, foram destacadas as diferenças nas formas como cada uma delas foi se readequando para atender às exigências de um mercado que deveria ser um durante os anos de 1850, e outro, nos idos da década de 1870 .

O primeiro anexo a este trabalho trata-se de um quadro legislativo dos seguros, e traz consigo informações referentes aos séculos XVII, XVIII e XIX. O segundo é o já mencionado Quadro Companhias de Seguros em funcionamento na Província do Rio de Janeiro (1808-1889), elaborado para que servisse às análises principalmente dos capítulos dois e três da dissertação. $\mathrm{O}$ anexo seguinte apresenta alguns dos problemas com que nos deparamos quando da elaboração do referido quadro, e as soluções adotadas para que não restassem dúvidas quanto à identidade das companhias de seguros. O quarto anexo torna conhecidos os nomes que compuseram os quadros diretivos e administrativos das seguradoras de vida de escravos, e também os endereços em que instalaram seus escritórios ou por onde realizaram seus negócios. O quinto e último anexo, por sua vez, é a transcrição de uma apólice de seguros de vida de escravos tal qual costumava subscrever a companhia Feliz Lembrança. Por ela vão relacionadas as condições gerais dos seguros, que deveriam ser observadas por ambas as partes contratantes, e também as condições particulares, que 
ditariam as regras regentes da relação mantida entre o segurador e o proprietário segurado contra a morte de algum de seus escravos.

Nem todas as informações trazidas pelos anexos chegaram a compor a narrativa de qualquer um dos três capítulos da dissertação. Mas, por se entender que esta pesquisa busca explorar um tema ainda não muito em evidência, por isso optamos por organizar essas informações em quadros para que possam ser aproveitadas por investigações futuras. 


\section{CAPÍtulo 1: O TRÁfico SEgURO NA PROVÍNCIA DO RIO DE JANEIRO - PRIMEIRA METADE DO SÉCULO XIX.}

\section{Com a Corte, a Grã-Bretanha}

Quando o mês de novembro de 1807 estava por terminar, em Portugal, milhares de pessoas se aprontavam para atravessar o Atlântico rumo às terras que, quinze anos mais tarde, viriam a ser o Império do Brasil. Embarcaram em não mais que cinco dezenas de navios, todos protegidos pela armada britânica; e pouco menos de dois meses de viagem pelo oceano foram suficientes para que o Príncipe Regente D. João aportasse sem maiores problemas na Bahia, em 22 de janeiro do ano sequente. Depois de breve estadia nesta capitania, partiu em direção à do Rio de Janeiro, aonde chegou no dia 7 de março desse mesmo ano de 1808. Aí se estabeleceu indefinidamente, sem que lhe fosse possível prever a data em que retornaria à península de onde foi praticamente obrigado a zarpar. Pela primeira vez o mundo assistira ao traslado de uma Corte, que deixou as convulsões da Europa e se instalou numa das colônias que compunham a extensa área de seu império.

Ao que nos parece, tratou-se apenas do sucesso de uma antiga estratégia presente na orientação política portuguesa desde pelo menos meados do século XVII, promovida que foi pelo acúmulo das situações que tornaram impossível a permanência da Corte no seu território europeu. Pois, se foi a primeira vez que a Europa presenciou o traslado de uma Casa Real para alguma de suas colônias do além-mar, os lusitanos já haviam cogitado essa possibilidade - pautada por suas conjunturas específicas - por volta de 1640 , durante o reinado de D. João IV, em meio à Restauração da independência do trono português, uma vez sob o governo da dinastia espanhola; e à expulsão dos holandeses do nordeste brasileiro, região cobiçada pela sua produção açucareira e pela sua proximidade com os mercados europeu e africano. Em outros momentos de dificuldade, como nos meados do século XVIII, os portugueses de igual modo pensaram em cruzar os mares depois de sobreviverem às consequências do terremoto que sobreveio a Lisboa (1755) e, novamente, durante a Guerra dos Sete Anos (1762).

A partir da última década do século XVIII e primeiros anos do século seguinte,

época que se tornou o palco para as guerras napoleônicas que vinham desordenando o mapa político europeu, a possibilidade da transferência da Coroa portuguesa para sua 
colônia americana novamente começava a acenar nos círculos políticos da metrópole. Em 1801, durante a Guerra das Laranjas, D. José Maria de Souza Botelho, então embaixador português em Madri, cogitou-a aproveitando convenientemente o momento para trazer à baila um projeto tanto mais audacioso, qual seja, o de fundar na América o maior dos impérios do mundo, pois, por estarem aliadas França e Espanha contra Portugal, a conquista de colônias espanholas vizinhas ao Brasil estaria mais que justificada nesses tempos tormentosos da estabilidade política das nações; plano que bem poderia combinar a sobrevivência mesma da Família Real com um golpe nada moderado nos domínios de seus inimigos. Por suas razões, esta proposta foi descartada. Poucos anos depois, em 1803, diante da iminência de uma guerra entre a França e a Grã-Bretanha, D. Rodrigo de Sousa Coutinho, o então Ministro do Reino de Portugal, também recomendou a transferência da sede da Corte para uma de suas colônias, mas sua saída do ministério acabou por arrefecer a discussão em torno de seu parecer. Foi somente no ano de 1807, quando a guerra francobritânica já tinha estourado e vinha apertando o cerco contra a neutralidade política de D. João, que o Conselho de Estado lusitano passou a buscar assiduamente uma solução à situação em que Portugal estava envolvido. Chamou reuniões de agosto a novembro, e foram nessas ocasiões que a possibilidade da mudança da Corte para sua colônia americana foi se tornando cada vez mais realizável, à medida da iminência de uma invasão francoespanhola do território português. O que acabou acontecendo no dia 30 de novembro de 1807, um dia após a Família Real bragantina ter se retirado para o Brasil em embarcações escoltadas por navios da marinha britânica ${ }^{31}$.

Uma aliança com a Grã-Bretanha nessa passagem do século XVIII para o XIX não era uma opção a ser facilmente descartada pelos portugueses. E o poder então acumulado pelos britânicos fora o resultado de uma orientação político-econômica, e mesmo militar, sempre desejada nas suas relações comerciais e diplomáticas havia no mínimo cerca de duzentos anos. Pelo menos desde a primeira metade do século XVII o mundo poderia muito bem estar presenciando o nascimento daquela que em séculos posteriores viria a se constituir na toda poderosa senhora dos mares. Seja colocando-se ao lado dos portugueses quando estes reclamaram a independência de seu trono, já que unido ao da Espanha, seja concedendo seu apoio aos lusitanos quando estes pretenderam expulsar seus rivais

\footnotetext{
${ }^{31}$ Como se vê, a transferência da Corte somente fora aceita como última alternativa para que a Coroa lusitana driblasse as conturbadas agitações europeias que, mais cedo ou mais tarde, bem poderiam lhe afetar diretamente: era preferível evitar o confronto direto com o exército de Napoleão, cf. SLEMIAN, Andréa; PIMENTA, João Paulo G., A Corte e o mundo, p. 42-55.
} 
holandeses do nordeste brasileiro (principalmente das capitanias da Bahia e, mais tarde, de Pernambuco), seja promovendo o matrimônio de alguns membros da Coroa britânica com os de outras Casas Reais - como fora o caso do casamento de Carlos II, um Stuart, com Catarina de Bragança, no início da década de 1660 -, os ingleses aumentaram em número seus domínios por toda parte do mundo; intensificaram sua influência sobre a orientação político-econômica de algumas potências europeias, ou mesmo de suas possessões na América, África ou Ásia; e, não menos importante, dominaram superiormente as rotas comerciais mundiais que, logo na virada do século XVIII para o século XIX, proporcionarlhes-iam grandes vantagens à consolidação de suas indústrias que, pelo escoamento de suas produções - tanto de bens de capital como de consumo - para outras potências ou para as colônias destas potências, já vinham havia algum tempo se constituindo num dos pilares da estrutura econômica da Ilha, e que passaria a nortear, daí em diante, seu posicionamento político perante os outros estados no instável jogo das nações.

De fato, as investidas contra os holandeses no Atlântico os provocaram a partir em busca de outros mares que ainda lhes garantissem a continuidade no lucrativo e perigoso ramo do comércio marítimo internacional. Dirigiram-se ao oriente onde, ao que parece, as águas mais tranquilas do Índico favoreceram sua dedicação às negociações com os territórios asiáticos. Em contrapartida ao enfraquecimento holandês, foi-se consolidando o predomínio dos ingleses sobre o comércio triangular do Atlântico o qual, além de lhes beneficiarem uma imensa participação nas lucrativas transações comerciais às quais se viam envolvidas a Europa e os domínios ultramarinos americanos e africanos, ainda lhes possibilitaram um razoável controle sobre o fornecimento de produtos europeus, e principalmente africanos, às possessões do Novo Mundo e, na viagem de volta, um razoável controle sobre a distribuição dos produtos provenientes das colônias americanas, no Velho Continente. Foi assim que algodão, açúcar, tabaco, e também ouro e prata, chegaram a ser disponibilizados aos mercados da Europa, enquanto daí partiam rum, tecidos de algodão, armas de fogo, dentre outros manufaturados, a serem trocados, sobretudo na costa da África Ocidental, por cativos africanos que, passados mais alguns meses de viagem, viriam a ser vendidos nas colônias inglesas da América do Norte (principalmente no Sul dos territórios que, na segunda metade do século XVIII, viriam a se juntar nos Estados Unidos), nas colônias espanholas (com maior intensidade no Caribe) e, por fim, na única colônia portuguesa da América: o Brasil. Talvez o tráfico negreiro para essas regiões fosse o negócio mais lucrativo e dependia de investimentos avultados para 
que pudesse ser convertido em somas ainda maiores de capital. Mas, sem dúvida, era um empreendimento chave que proporcionava a continuidade de toda essa valiosa movimentação de lado a lado do Atlântico, pois, uma vez que constante a necessidade de reposição da mão-de-obra nas plantations coloniais, os escravos passariam a ser a principal força de trabalho empregada na produção das mercadorias que voltariam a abastecer, passado algum tempo, os mercados europeus.

O que ainda delinearia o poderio econômico britânico, principalmente durante todo o século XIX, seria seu poder de comando exercido sobre as finanças do mundo, o que já vinha se despontando desde pelo menos as primeiras décadas do setecentos. Por essa época, a Ilha começara a demonstrar a sua capacidade de atrair o capital excedente holandês para fora do continente, muito embora essa tendência tenha se intensificado mesmo a partir da década de 1740. O século XVIII presenciou essa competição entre Londres e Amsterdã por uma posição privilegiada no controle das altas finanças europeias, e, portanto, de boa parte do mundo. Mas quando a Holanda foi abatida por uma crise entre 1780 e 1783, portanto às vésperas das guerras napoleônicas, quem acabou por se sobressair como um poderoso pólo de atração e direcionamento do investimento do capital que circulava pela Europa, foi a Inglaterra. Alguns anos mais tarde, durante um período que se arrastaria por cerca de vinte anos (1792-1815), esse poder financeiro recém conquistado pelos britânicos lhes garantiria o acesso a um crédito quase ilimitado de capital e que lhes foi suficiente para o enfrentamento às investidas francesas, contrárias aos seus projetos político-econômicos e à harmonia das nações da Europa. Essas mesmas décadas que inauguraram as intenções imperialistas de Napoleão sobre o território europeu, mas que também as encerraram no Congresso de Viena, proporcionaram praticamente a sextuplicação dos gastos públicos ingleses, desencadeando um notável crescimento de suas indústrias de bens de capital, especialmente as siderúrgicas produtoras de navios de aço e vias férreas ${ }^{32}$.

As locomotivas, que durante todo o século XIX foram disseminadas pelo mundo, fizeram diminuir as distâncias entre as regiões produtoras de mercadorias, principalmente aquelas destinadas aos mercados estrangeiros - como é o caso do café brasileiro - e as cidades portuárias de onde seriam escoadas para o exterior. As vias férreas não só propiciaram o barateamento do custo do transporte desses produtos até os portos, e, por conseguinte a diminuição de seus preços de venda, como também possibilitaram a

\footnotetext{
${ }^{32}$ Para uma história da hegemonia britânica nos séculos XVII, XVIII e XIX, cf. ARRIGHI, Giovanni, $O$
} Longo século XX, principalmente o Capítulo 3, p. 163-164, 203-204, 209-210. 
expansão das áreas reservadas ao plantio a rincões mais distantes, em direção a um interior outrora desocupado ou de difícil acesso. As redes de comércio, anteriormente restritas quase que exclusivamente às rotas marítimas, ampliaram-se simultaneamente à intensificação do fluxo do próprio comércio. Mas, toda essa estrutura que favorecia o mercado estava a depender, dentre outros fatores, do incentivo à criação de novos mercados. E, quanto mais mercados, maior o volume de produtos a serem por eles importados e, portanto, maior o volume dos lucros, via comércio, do capital investido na produção.

A partir de fins do século XVIII e início do século XIX, então, a Grã-Bretanha, principal potência político-econômica do mundo, passaria a estimular o surgimento desses mercados consumidores na América. Uma de suas principais características seria a exigência do emprego de trabalhadores livres, e não mais escravos, na produção das mercadorias a serem disponibilizadas ao comércio. E isso viria de encontro aos interesses político-econômicos de alguns estados europeus e de seus domínios ultramarinos que, não mais que Portugal - e posteriormente após 1822, como o Brasil -, encontravam no tráfico negreiro africano um dos negócios mais lucrativos aos seus particulares, e que melhor rendiam aos cofres estatais. O que se sucedeu à época, no entanto, é que nem Portugal nem o Brasil estiveram em condições de contestar essa vontade da senhora dos mares, imposta em algumas ocasiões pela assinatura de tratados, e em outras pela ameaça militar. Mais cedo ou mais tarde o tráfico negreiro, negócio tão lucrativo, mas também repleto de riscos, seria abolido a contragosto dos que desejassem perpetuar a escravidão que, aliás, também estaria com seus dias contados.

Nos últimos meses de 1807, quando o Conselho de Estado português convocara sessões preocupadas em vislumbrar uma solução à situação que enredava a sede do Reino lusitano aos conflitos que acometiam a Europa, a Inglaterra já contava com poder suficiente para garantir, com alguma segurança, o traslado da Família Real bragantina, bem como de sua Corte, a uma de suas colônias ultramarinas. De fato, os planos de Napoleão e seus aliados vinham limitando as possibilidades do governo português, e escapar da península sob a escolta britânica poderia muito bem significar procurar escapar dos efeitos desastrosos que um eventual confronto militar com o exército francês, ao que parece belicamente superior ao de D. João, provocaria nos alicerces da monarquia lusitana. 
Tal situação conturbada por que passava a Europa desde a última década do século XVIII, e que de igual modo afetava a antiga sede do Reino, acabou oferecendo, sem dúvida, os motivos que levaram a Corte, em 1807, a se transferir para o além-mar. Nesse sentido, a mudança de boa parte dessa elite político-econômica para a colônia americana colocava em jogo, além da segurança e garantia da integridade física dos Bragança, a possibilidade de contornar as dificuldades impostas à manutenção de um governo português em solo europeu. Ou, em outras palavras, a chegada dessa elite, bem como sua sequente acomodação na capitania do Rio de Janeiro, viria exprimir o desejo de D. João em dar continuidade ao governo de seu império ultramarino, pois, ainda que suas ordens passassem a ser ouvidas não mais da península, mas de uma sua colônia situada ao sul do equador - que beirava o Atlântico assim como tantas outras o beiravam na costa ocidental da África -, assim, evitaria perder de vista o comando sobre as colônias africanas, asiáticas, e também sobre o restante do território do Brasil. A escolha da capitania do Rio de Janeiro para o abrigo da nova sede do governo lusitano, no entanto, não se deu por mero lance de sorte, tirada em um jogo cego no qual se detém o giro do globo na ponta do dedo. Pelo contrário, estaria adstrita à leitura que se fez da conjuntura que integrava a colônia americana às relações comerciais e políticas mantidas com as potências econômicas, ou mesmo com outras colônias, portuguesas ou não.

De fato, pelo menos durante a segunda metade do século XVIII, a cidade do Rio de Janeiro já exportava e importava mercadorias que partiam ou chegavam pelas rotas comerciais transatlânticas, sejam as que se comunicavam com Portugal (Lisboa, Porto, Viana), ou as que atravessavam o oceano até a África (Angola, Guiné). A navegação de cabotagem vinha sendo muito utilizada para o comércio que se realizava com Angra dos Reis e Parati (ao sul da capitania), Cabo Frio e Campos (ao norte), com as capitanias costeiras de Santa Catarina, Rio Grande do Sul e Colônia do Sacramento, e também com as capitanias situadas no nordeste da colônia ${ }^{33}$. Do último lustro do século até o ano anterior ao da chegada da Família Real à cidade do Rio de Janeiro, o porto da capitania fora responsável pela exportação de um terço dos produtos que daqui partiam para a satisfação das demandas de mercados externos, ao mesmo tempo em que servia ao desembarque de pouco mais de um terço das importações brasileiras ${ }^{34}$. A partir do porto, os produtos

\footnotetext{
${ }^{33}$ Cf. LOBO, Eulália Maria Lahmeyer, Economia do Rio de Janeiro nos séculos XVIII e XIX, p. 128.

${ }^{34}$ Manolo Florentino fornece os números das exportações e importações do porto da cidade do Rio de Janeiro, para o período, comparativamente aos dados obtidos para o porto da Bahia: "Comparando-se com a Bahia, por então o Rio detinha 38\% das importações e 34\% das exportações brasileiras, enquanto que aquela região registrava $27 \%$ e 26\%, respectivamente”. Cf. FLORENTINO, Manolo, Em Costas negras, p. 31.
} 
importados passariam a ser distribuídos nas regiões interioranas da própria capitania ou mesmo da colônia. Se fossem encaminhadas para São Paulo, por exemplo, certamente passariam por "Penha, Mogi das Cruzes, Taubaté, Hecarapé (próximo à atual Lorena), atravessava a Mantiqueira e atingia Ribeirão do Carmo e o rio das Velhas" ${ }^{\text {"35. }}$

Desde meados do século XVIII, a cidade do Rio de Janeiro e seus arredores vinham se tornando um elo importante de comunicação com o restante da capitania, bem como da região centro-sul da colônia com pelo menos parte do mercado mundial, seja abastecendo essas localidades com os produtos vindos do exterior, seja proporcionando o escoamento de suas produções em direção ao estrangeiro. Por outro lado, por essa mesma época e pelos anos que se seguiriam até a chegada da Família Real à cidade, o Rio de Janeiro seria beneficiado por certa combinação de fatores internacionais e internos à região, que viria ocasionar uma expansão de algumas culturas agrícolas. As últimas décadas do Setecentos puderam presenciar um aumento no plantio de cana-de-açúcar, produto, dentre outros, destinado especialmente aos mercados estrangeiros. Em decorrência disso, a demanda por força de trabalho a ser empregada nas lavouras também aumentou, e o crescimento demográfico da região passou a ganhar ritmo por volta dos anos de 1760, seja devido à sua capacidade de absorver a mão de obra escrava, a baixos custos, proveniente das regiões auríferas de Minas Gerais, em declínio desde meados do século e recém convertida a uma economia basicamente de subsistência; ou seja porque nos portos da capitania os negreiros desembarcavam constantemente cativos capturados no continente africano, o que permitia a fácil disponibilidade dos escravos no mercado e, por conseguinte, a compra e reposição da mão de obra necessária à continuidade do plantio de quaisquer culturas agrícolas ${ }^{36}$.

A colônia portuguesa da América, ao que parece, vinha se distinguindo dentre as colônias que compunham o império ultramarino lusitano havia pelo menos meio século, sendo que boa parte da receita metropolitana destinada ao sustento de uma sociedade arcaica advinha das arrecadações a que estavam obrigadas as rendas provenientes de suas transações comerciais com as colônias africanas estabelecidas no lado oposto do Oceano Atlântico e também no Índico. Única colônia portuguesa na América, o Brasil progressivamente vinha se revelando um centro econômico que bem poderia ser capaz de

\footnotetext{
${ }^{35}$ Cf. LOBO, Eulália Maria Lahmeyer, op.cit., p. 128. A autora ainda complementa: "Para realizar esse percurso gastava-se, em média, três meses. Havia ainda uma picada para Santos e outra de Taubaté a Parati, cruzando a Serra do Mar. A abertura de uma via mais direta, o caminho novo que transpunha a Serra do Mar próximo ao Rio de Janeiro para atingir o Vale do Paraíba e seguia o Paraibuna [rio] até a zona de mineração, encurtou a duração da viagem de três meses para uma média de 10 a 12 dias".

${ }^{36}$ Ibidem, p. 132, 140, 147; FLORENTINO, Manolo, op.cit., p. 39.
} 
arrimar a sobrevivência do Reino lusitano, ainda mais por esses tempos de instabilidade política que vinha preocupando quase todos os países europeus. Nesse sentido, se escapar a um confronto militar com o exército francês, zarpando da Europa, veio a manifestar a aspiração da Coroa Real em dar continuidade ao governo de seu império, então as mentes dos estadistas metropolitanos que se reuniram durante os últimos meses de 1807, nas sessões do Conselho de Estado, deveriam inquietar-se por uma solução que, estrategicamente, perpassasse pela proteção física e também pelo zelo às potencialidades econômicas do Brasil.

A chegada da Corte ao continente americano parece ter dado conta de amenizar algumas dessas preocupações, uma vez que conseguiu evitar o desmembramento territorial da colônia em meio às profundas transformações que, nos séculos XVIII e XIX, remodelariam o mapa político da América ao tom das novas relações que envolviam as potências europeias e muitas das suas colônias no ultramar, como foi o caso notório do império espanhol. Ao que parece, o estabelecimento da Corte na cidade do Rio de Janeiro pode ter resolvido, ou ao menos abrandado, o que bem poderia estar se constituindo numa tendência política a ser assumida também por algumas regiões da colônia: o fato é que dentro de seus próprios limites geográficos algumas capitanias levantaram-se em contestação da secular relação que mantinham com Portugal. Era preciso, portanto, evitar que os anseios separatistas de Minas Gerais (1789) e, uma década depois, os da Bahia (1798), alcançassem outros rincões da América portuguesa, ao mesmo tempo em que suas fronteiras deveriam ser mantidas cerradas à onda que vinha varrendo as colônias espanholas suas vizinhas, e que vinha lhes proporcionando maior autonomia políticoadministrativa em face do enfraquecimento político dos Bourbons que, nesses anos da primeira década do século XIX, já se encontravam quase impossibilitados de exercerem um governo legitimamente espanhol.

O perigo à solidez do território brasileiro existira em parte por certa agitação interna, e em parte em decorrência do conhecimento da porosidade que afetava as suas fronteiras, tanto as que demarcavam a colônia no interior do continente, como também sua extensa costa atlântica. Nesse mesmo sentido, uma aliança com os ingleses pode ter rendido à Casa dos Bragança algo além do comboio que lhe proporcionou a transferência para o Brasil. Em guerra declarada aos franceses e seus aliados na passagem do século XVIII para o século XIX, a Inglaterra, que viria a se tornar a potência hegemônica do oitocentos, já poderia garantir à Coroa portuguesa sua proteção a Portugal e, além de seu 
território na Europa, também a algumas de suas possessões ultramarinas, inclusive a região litorânea daquela que fora escolhida para abrigar a nova sede do governo lusitano: seja isolando suas águas costeiras de eventuais incursões inimigas, seja esmorecendo a própria possibilidade de uma investida britânica, o que já ocorrera em desfavor das colônias espanholas de Buenos Aires e Montevidéu nos anos de 1806 e $1807^{37}$.

Tudo isso, certamente, pode muito bem ter contribuído para que a Coroa portuguesa optasse por deixar Portugal e cruzar o Atlântico em direção à sua possessão americana. A transferência de D. João e sua Corte para a capitania do Rio de janeiro, bem como a sua acomodação na mesma cidade que às vésperas de sua chegada servira à sede do governo geral da colônia, de certa forma buscou preservar a monarquia dos ventos revolucionários soprados de mais a leste do continente europeu e, por conseguinte, resguardar-lhe a continuidade da administração de seus domínios ultramarinos da África, da Ásia, e também do restante da América. Mas, por outro lado, a integridade do Império lusitano estaria a depender na só da capacidade do governo português em adaptar-se politicamente, mas também em termos econômicos, ao novo ambiente escolhido para seu estabelecimento: o Brasil. Ou, em outras palavras, dependeria, em algum grau, de sua capacidade de governar o Império a partir de uma nova realidade, nem tão estranha, digamos, mas aonde viria a se aproximar de uma conjuntura costurada por relações de forças até então nem tão aparentes.

Foi em meio a esse cenário prolongado aos anos que se seguiram à instalação da Corte no Rio de Janeiro, que operaram as (re)criações das instituições necessárias à boa administração do interesse público, ou seja, do interesse do Reino; e também o incentivo às medidas político-econômicas simultaneamente adotadas em benefício dos interesses particulares dos súditos da Coroa, mas que de igual maneira atuaram em favor do incremento da riqueza nacional. Por aí começaram a serem alavancadas algumas das causas de algo invisível à primeira vista, mas que nem por isso passaram despercebidas aos olhos dos coevos. É que, concomitantemente a estes acontecimentos, porém em sentido contrário às primeiras pretensões que os trouxeram à América, à medida que a Corte ia aqui se estabelecendo e governando, e à medida que a conjuntura europeia ia se normalizando, principalmente a partir de meados da década de 1810, a vinda dessa elite portuguesa para o Rio de Janeiro ia se alimentando de significados distintos tanto para aqueles que aqui já residiam, ou que por aqui desejaram permanecer após o retorno de D. João VI a Portugal, como para aqueles que vieram ao Brasil apenas de passagem, sem se

${ }^{37}$ Cf. SLEMIAN, Andréa; PIMENTA, João Paulo G., op.cit., p. 44; Cf. SLEMIAN, Andréa; PIMENTA, João Paulo G., $O$ 'Nascimento político' do Brasil, p. 16-17. 
despirem da aspiração de preservar, mesmo após uma breve estadia longe da península ibérica, a tradicional relação que a metrópole vinha havia séculos mantendo com suas colônias ultramarinas.

De fato, se nos fosse lícito afastar o olhar do presente daqueles acontecimentos, ou mesmo do que já se fora um passado remoto e, ainda que por um instante, lançá-lo nas vias de um futuro de cerca de meio século da história do Brasil, perceberemos que a breve permanência da elite metropolitana, instalada principalmente na cidade do Rio de Janeiro, de alguma forma contribuiu para a celeridade dos processos de independência política e econômica que naquela colônia estariam prestes a ocorrer. Em outras palavras, aqueles navios desembarcaram da Europa algo além da Família Real, dos homens de Estado e de boa parte do aparelho burocrático português. E quando resolveram levantar acampamento dessas terras de aquém mar, já não puderam levar consigo tudo o que haviam trazido.

\section{Com a Corte, o Comércio}

O ano de 1808 trouxe consigo inúmeras possibilidades econômicas ao Novo Mundo, que, logo da chegada da Corte ao Rio de Janeiro, passariam a se imiscuir no cotidiano da sociedade luso-brasileira acomodada no continente americano. Foi um ano que marcou uma transformação profunda na disposição das instituições políticoadministrativas até então estabelecidas na cidade que, a partir dali, deveria ceder espaço à reorganização da capital do Império ultramarino português, uma vez que a comunicação com as instituições da antiga metrópole andava prejudicada em decorrência da situação conturbada por que passava a Europa. Mas a montagem de todo esse aparato burocrático, assim como o próprio sustento da Família Real, exigiria que os estadistas mais cedo ou mais tarde organizassem a arrecadação das rendas que viessem a custear o novo governo. Transcorridos alguns meses desde a chegada de D. João e sua comitiva ao Rio de Janeiro, então, o Erário Régio foi criado, no fim de junho de 1808, “com as mesmas prerrogativas, jurisdição e inspeção, autoridade, obrigações e incumbências especificadas na Carta de Lei de 22 de Dezembro de 1761 que estabeleceu o Real Erário de Lisboa”.

O órgão seria composto por um Presidente, um Tesoureiro Mor, um Escrivão de sua receita - estes seriam os membros que formariam a Mesa do Erário - e três Contadores Gerais, ficando a cargo de cada uma dessas Contadorias a arrecadação das rendas 
provenientes de diferentes regiões do Império português ${ }^{38}$. Assim, a segunda Contadoria ficara responsável pela "contabilidade e cobrança das rendas" provenientes da região centro-sul do Brasil (Goiás, Mato Grosso, Minas Gerais, São Paulo e Rio Grande de São Pedro do Sul), da Ásia Portuguesa e da África Oriental; a região mais a norte da sede do governo (Bahia, Pernambuco, Pará, Maranhão, Ceará, Piauí e Paraíba), assim como a África Ocidental e as Ilhas de Cabo Verde, Açores e Madeira, estariam sob a circunscrição da terceira Contadoria Geral; a primeira delas, por sua vez, estaria reservada aos negócios da capital e da província do Rio de Janeiro: ela deveria arrecadar e escriturar "as rendas que devem nele [no Erário] entregar todos os Tesoureiros, Almoxarifes, Recebedores, Administradores, Provedores, Exatores e Contratadores dos reditos e direitos reais". Fora uma tentativa, ao que parece, de se exercer maior controle e fiscalização, e portanto de arrecadar mais, sobre uma movimentação econômica que começava a se intensificar, e que provavelmente estaria, em algum grau, desgovernada.

A nova sede política do governo português foi sendo então paulatinamente arquitetada em meio à confluência dos interesses da Real Coroa com alguns dos interesses econômicos dos seus vassalos, estivessem eles no Brasil ou nas outras colônias ultramarinas. Parece ter sido notório aos coevos que a incomunicabilidade com Portugal não afetou somente os interesses da Administração do Império lusitano, mas também prejudicara o andamento dos negócios em que estava metida boa parte de sua elite mercantil. Pelo menos aqueles negócios ainda dependentes de decisões a serem expedidas por algumas instituições oficiais. E, por isso também, seria razoável se medidas fossem desde pronto tomadas para que a continuidade da Administração fosse preservada e, ao mesmo tempo, para que se evitassem maiores inconvenientes e prejuízos aos tratos dos particulares, ou mesmo, às últimas consequências, a derrocada do Trono português.

Antes mesmo da criação do Erário Régio, já em abril do mesmo ano de 1808, cerca de mês e meio após sua chegada à cidade do Rio de Janeiro, D. João criou o Tribunal da Mesa do Desembargo do Paço e da Consciência e Ordens ${ }^{39}$. A função do novo tribunal

\footnotetext{
${ }^{38}$ Cf. Alvará de 28 de junho de 1808. Quanto à formação da Mesa do Erário ainda poderiam compô-la "o Procurador da Fazenda, o Contador Geral respectivo, ou outro qualquer Ministro e pessoas", se o Presidente assim entendesse para o bom andamento dos trabalhos, mas tudo de acordo com o Alvará de 17 de Dezembro de 1790. Todas as citações que seguem a respeito da criação desse órgão são excertos retirados do texto do mencionado Alvará. Sobre a submissão do órgão à forma do Real Erário de Lisboa e sobre sua composição, confira item I, Tít. I; sobre a Mesa do erário, confira item II, Tít. I; sobre as Contadorias Gerais, confira itens IV, V, VI e VII, Tít. I.

${ }^{39}$ Cf. Alvará de 22 de abril de 1808. Dos negócios antes apreciados pelo Conselho Ultramarino e que passariam a ser decididos pelo Tribunal da Mesa do Desembargo do Paço e da Consciência e Ordens estavam excluídos os negócios militares, "porque estes pertencem ao Conselho Supremo Militar, na forma do
} 
seria a de decidir todas as causas a ele submetidas, desde que fossem da competência da Mesa do Desembargo do Paço, do Conselho Ultramarino, e da Mesa da Consciência e Ordens, cuja "arrecadação da fazenda dos defuntos e ausentes" constaria do rol de suas responsabilidades. A composição do órgão estaria restrita a um Presidente, Desembargadores, e Deputados da Mesa da Consciência e Ordens "que só entenderão nos negócios dela"; além, como não podia deixar de ser, de outros cargos tão necessários para o bom andamento do expediente. Uma vez interrompida a comunicação com a metrópole, a criação deste Tribunal consistiu numa medida que buscou, como assim dissera a exposição de motivos do documento que o afirmou, "atalhar e remediar os inconvenientes" decorrentes da impossibilidade da decisão dos Tribunais do Reino sobre os negócios que lhes eram correntes. Das decisões desses tribunais dependiam "o sossego e prosperidade" dos vassalos de D. João, e, por conseguinte, o sustento da "ordem e tranquilidade pública". Por essa mesma razão parece explicar-se a opção pela permanência da Mesa do Desembargo do Paço na Relação da Bahia, pois, do contrário, os interesses dos habitantes de seu distrito seriam prejudicados caso seus negócios tivessem de viajar longas distâncias até serem apreciados pelo Tribunal recém criado no Rio de Janeiro. Por outro lado, a mesma Mesa, porém a situada na Relação da capital, esta seria abolida e os negócios por ela até então decididos passariam à competência do novo Tribunal.

A Relação do Rio de Janeiro ${ }^{40}$ passaria ainda por outra transformação. É que algumas semanas depois de diminuída sua competência, e sob os mesmos propósitos de desembaraço da Justiça, "que afiança a segurança pessoal e dos sagrados direitos de propriedade que muito desejo [o Príncipe] manter como a mais segura base da sociedade civil", a Relação da capital do Império ultramarino português seria elevada à condição da Casa da Suplicação ${ }^{41}$ do Brasil. De fato, as circunstâncias coetâneas estavam propícias à

\footnotetext{
Alvará de 1 de Abril do corrente ano [1808]”. (item I) Todas as citações correspondem a trechos extraídos do texto do Alvará: sobre a jurisdição do novo Tribunal, confira item I; sobre matérias que seriam do entendimento da Mesa da Consciência e Ordens, veja o item VIII; sobre a composição do Tribunal, confira item II; sobre a abolição da Mesa do Desembargo do Paço da Relação do Rio de Janeiro, e sobre a permanência da mesma Mesa, porém a da Relação da Bahia, confira os itens IV e V, respectivamente. O Alvará ainda regularia o expediente (item III); os empregos e ordenados (itens X-XII). No mês de agosto do mesmo ano, o Alvará do dia $1^{\circ}$ criaria outros ofícios para a Mesa do Desembargo do Paço. Mas, aos 22 de setembro de 1828, no entanto, apenas quatro dias após a criação do Superior Tribunal de Justiça (18.09.1828), o Tribunal da Mesa do Desembargo do Paço e da Consciência e Ordens foi extinto. Cf. NEQUETE, Lenine. O Poder Judiciário no Brasil a partir da Independência (I - Império), p. 19-20; Apêndice I, p. 141-143.

${ }^{40}$ Cf. Alvará de 13 de outubro de 1751, o Regimento da Relação do Rio de Janeiro. Cf. NEQUETE, Lenine, O Poder Judiciário no Brasil: crônicas dos tempos coloniais (Vol. I), p. 263-300.

${ }^{41}$ Cf. Alvará de 10 de maio de 1808. Todas as citações empregadas neste parágrafo são fragmentos do texto do mesmo Alvará: sobre a elevação da Relação do Rio de Janeiro à condição de Casa da Suplicação do
} 
transferência da Casa da Suplicação de Lisboa para a colônia americana, pois, além de hospedar a nova residência da Real Coroa, a incomunicabilidade com o território europeu embaraçava a remessa e o julgamento dos agravos ordinários e das apelações e, consequentemente, deixava "os pleitos sem decisão última com manifesto detrimento dos litigantes e do público que muito interessam que não haja incerteza de domínios e se findem os pleitos o quanto antes". À nova Casa, então, a ter-se em conta como Superior Tribunal de Justiça, deveriam ser interpostos "todos os agravos ordinários e apelações do Pará, Maranhão, Ilhas dos Açores e Madeira, e da Relação da Bahia", os quais anteriormente, em tempos de paz, eram remetidos a Lisboa; e das últimas decisões proferidas por qualquer uma de suas Mesas somente caberia o recurso de revistas. Em se tratando dos casos em que já houvera interposição de agravos ou apelações, remetidos ou não para Portugal, uns e outros deveriam ser decididos na Casa da Suplicação do Brasil, porém, uns pelos traslados que ficaram, e outros pelos próprios autos que não foram. Mas todos eles, invariavelmente, seriam decididos pelo mesmo modo como o seriam na Casa de Lisboa.

Passavam-se os meses, e os anos e, ao que tudo indica, a organização políticoeconômica da nova sede do governo lusitano ainda estava por ser cumprida, ou pelo menos realizável naquilo que os coevos entendiam ser as condições mínimas para uma boa administração do Reino ${ }^{42}$. Vimos percebendo que a instituição de alguns tribunais manifestava constante preocupação com a satisfação dos particulares quanto ao bom encaminhamento das questões referentes aos seus negócios, pois, como de muitas delas estariam a depender seus sucessos ou insucessos econômicos, a impossibilidade do julgamento ou mesmo a demora por uma decisão poderiam deteriorar as expectativas que lançavam sobre seus investimentos.

Brasil, bem como o ter-se como Superior Tribunal de Justiça, veja item I; a respeito da competência do órgão, confira itens I, II e III; sobre a composição da Casa, veja itens IV-VIII, XII e XIII; sobre os ordenados, confira o item XI. Alguns meses depois, outra Carta, o Decreto de 29 de julho, providenciou sobre o expediente da Casa do Brasil. Cf. NEQUETE, Lenine. O Poder Judiciário no Brasil a partir da Independência (I - Império), Apêndice I, p. 137, 140-141.

${ }^{42}$ Várias outras instituições político-adinistrativas foram (re)criadas nesses anos que se estendiam à chegada da Corte ao Rio de Janeiro. Optamos por descrever apenas algumas que, dentre outras, revelavam certa preocupação com os interesses dos particulares, em boa parte interesses econômicos, e, por conseguinte, com a própria manutenção da monarquia portuguesa. No ano de 1808, por exemplo, ainda foram criadas a Intendência Geral da Polícia da Corte e do Estado do Brasil pelo Alvará de 10 de maio, o mesmo dia em que a Relação do Rio de Janeiro foi elevada à condição de Casa da Suplicação do Brasil; o Chanceler Mor, criado pelo mesmo Alvará que instituiu o Tribunal da Mesa do Desembargo do Paço e da Consciência e Ordens, o de 22 de abril; e o Conselho Supremo Militar, criado pelo Alvará de $1^{\circ}$ de abril. 
Nesse sentido foi que, "exigindo mui particular consideração o comércio, agricultura, fábricas e navegação, pelos muitos proveitos que produzem a bem do interesse do Estado, multiplicando a riqueza e aumentando a população", D. João criou no Rio de Janeiro, na segunda metade de agosto de 1808, o Tribunal da Real Junta do Comércio, Agricultura, Fábricas e Navegação ${ }^{43}$ do Estado do Brasil e dos Domínios Ultramarinos. O órgão fora instituído para que entendesse de todas as matérias relativas às atividades econômicas que chegassem a compor seu nome, e invariavelmente viria resultar em "grandes utilidades em benefício comum dos meus fieis vassalos [dos de D. João] habitantes deste vasto e feliz continente", ou porque os negociantes contariam com um tribunal específico para o tratamento de suas contendas, que, como se esperava, deveriam ser apreciadas por entendedores do funcionamento e das necessidades do comércio, ou talvez porque encontrariam um lugar em meio ao aparato burocrático do Estado que lhes permitiriam defender seus interesses de classe, digamos assim, ou de grupos reduzidos dentro do corpo de negociantes.

A boa dinâmica do comércio e das inúmeras atividades econômicas desempenhadas em função da produção e venda das mercadorias, como se vê, vinham justificando a (re)criação de instituições político-administrativas que dessem conta de, em certo grau, contribuir para a regulamentação dos tratos realizados pelos súditos da monarquia portuguesa, residentes ou não no território que sediava o governo lusitano. Essas instituições, dentre outras que se criaram nesse ano de 1808 e nos próximos que se sucederam à chegada da Corte, dariam respostas e, por isso, vinham dar novos contornos a uma realidade paulatinamente modelada também por medidas econômicas, algumas delas que viriam repercutir tão profundamente nas bases da já secular relação mantida entre metrópole e colônia, e as enfraqueceriam de tal modo que o já fadado sistema colonial não poderia mais ser revigorado, quando assim foi pretendido, durante a primeira metade do século XIX.

Antes mesmo de se acomodar no Rio de Janeiro, logo na primeira semana de sua estada na Bahia, D. João ordenara uma das principais medidas econômicas que dariam ensejo à intensificação da atividade comercial em terras e em águas da colônia brasileira, e que ao mesmo tempo acabariam por subverter o domínio metropolitano sobre sua colônia

\footnotetext{
${ }^{43}$ Cf. Alvará de 23 de agosto de 1808. A citação anterior a esta nota, bem como as que ainda comporão o corpo do parágrafo, foi e serão retiradas do texto do documento. O Alvará ainda tratava da composição do Tribunal; e ainda afirmava que o Tribunal "Governar-se-á por todas as Leis, Alvarás, Regimentos e Ordens Régias que se acham estabelecidas nesta matéria e especialmente pela Carta de Lei de 5 de Junho de 1788”, esta última erigiu em Tribunal Supremo a Junta do Comércio criada pelo Rei D. José, avô de D. João.
} 
americana que já perduraria três séculos. Aos 28 de janeiro de 1808, então, D. João tratou de dar novo tom ao comércio português mediante ordem inspirada, ao que parece, por José da Silva Lisboa ${ }^{44}$. Ordenou que fosse admissível nas Alfândegas do Brasil a entrada de "quaisquer gêneros, fazendas e mercadorias transportados" tanto por navios estrangeiros como pelos portugueses, seus vassalos; e também que "quaisquer gêneros e produções coloniais" pudessem ser exportados, por esses mesmos estrangeiros e nacionais, para os portos "que bem lhes parecer a benefício do comércio e agricultura" do país ${ }^{45}$.

A ordem, portanto, mandava abrir os portos do Brasil ao comércio internacional. Porém, não o fez indiscriminadamente. Em primeiro lugar, os estrangeiros permitidos a negociar nos portos brasileiros foram aqueles súditos das Potências que conservavam a paz com o Império português. Em segundo lugar, os gêneros, fazendas e mercadorias que entrassem nas Alfândegas deveriam pagar "vinte e quatro por cento; a saber: vinte de direitos grossos, e quatro do donativo já estabelecido, regulando-se a cobrança destes direitos pelas pautas, ou aforamentos, por que até o presente [1808] se regulam cada uma das ditas Alfândegas". Os molhados - "vinhos, águas ardentes e azeites doces" - pagariam

\footnotetext{
${ }^{44}$ José da Silva Lisboa, o Visconde de Cairu, nasceu na Bahia, no dia 16 de julho de 1756 . Em 1774 viajou a Portugal para matricular-se nos cursos "jurídico e filosófico" da Universidade de Coimbra, vindo a se formar cinco anos mais tarde, em 1779, então com 23 anos de idade. Em 1797 obteve "a mercê [concedida pelo Príncipe Regente] de deputado e secretário da Mesa de Inspeção da cidade da Bahia, lugar que criou, e onde prestou os mais valiosos serviços à agricultura, e comércio da província”. Exerceu também a função de Censor Régio, uma vez nomeado desembargador da Mesa do Desembargo do Paço e da Consciência e Ordens. Com a criação do Tribunal da Real Junta do Comércio, Agricultura, Fábricas e Navegação, em 23 de agosto de 1808, foi nomeado Deputado, e comporia uma comissão encarregada de apresentar um projeto para o Código Comercial. No mesmo ano, ainda seria nomeado desembargador da Relação da Bahia. Em 1798, publica o primeiro dos oito Tratados que compõem os Princípios de Direito Mercantil e Leis de Marinha, obra finalizada em 1804, e que, nas palavras de Cândido Mendes de Almeida, "é o pedestal de sua glória e felicidade”. Em 1810 é publicado o opúsculo Reflexões sobre o Comércio dos Seguros, cuja autoria é atribuída a Silva Lisboa. O título de Barão de Cairu foi-lhe concedido em 1825 e, no ano seguinte, foi condecorado Visconde. Quando faleceu, em 20 de agosto de 1835, era Conselheiro do Superior Tribunal de Justiça, criado pela Lei de 18 de setembro de 1828, e Senador do Império. Cf. LISBOA, Bento da Silva, Biografia de José da Silva Lisboa, visconde de Cayrú, p. 185-191, texto do qual foi extraída a citação acima; ALMEIDA, Cândido Mendes, Ao Leitor, p. vi-vii, 961; SISSON, S. A., Galeria dos Brasileiros Ilustres, v. 1, p. 153-163; PENALVES ROCHA, Antonio, Introdução, p. 9-50. Sobre José da Silva Lisboa ser o incentivador da abertura dos portos do Brasil às nações amigas, Cândido Mendes de Almeida afirma, nas suas notas preliminares acrescentadas à edição dos Princípios de Direito Mercantil e Leis de Marinha, que "Não há quem ignore que a Carta Régia de 28 de Janeiro de 1808, dirigida ao Conde da Ponte, Governador e Capitão General da Bahia, abrindo os portos do Brasil ao Comércio estrangeiro, foi inspirada por Silva Lisboa ao Marquês de Aguiar, D. Fernando José de Portugal, então nas boas graças do Príncipe Regente, com quem o autor [Silva Lisboa] entretinha relações de amizade". E continua: "Sem a energia desse Estadista, atraído àquela medida pela luminosa argumentação de Silva Lisboa, nada então se houvera conseguido pela resistência do Príncipe Regente, e do monopólio do Comércio Português, que com razão via nessa medida a queda do seu predomínio". Cf. ALMEIDA, Cândido Mendes, op. cit., p. viii. Afora o tom ufanista com que Almeida se refere ao Visconde, essa informação é compartilhada pelos demais biógrafos: cf. LISBOA, Bento da Silva, op. cit., p. 186; SISSON, S. A., op. cit., p. 158-159; PENALVES ROCHA, Antonio, op. cit., p. 1214.

${ }^{45}$ Cf. Carta Régia de 28 de janeiro de 1808. Todas as citações deste parágrafo, bem como do próximo, são trechos retirados do corpo do texto do mencionado documento.
} 
o dobro; por outro lado, dos produtos liberados à exportação estavam proibidos o "Pau Brasil, ou outros notoriamente estancados", e pagariam pela sua saída os direitos previamente estabelecidos pelas capitanias. Ainda que essas ordens fossem provisórias, diante da falta de um sistema geral que viesse a regular a matéria, a Carta Régia estabeleceu ao seu final que estariam em "suspenso e sem vigor, todas as leis, cartas régias, ou outras ordens que até aqui proibiam neste Estado do Brasil o recíproco comércio e navegação entre os meus vassalos [os da Coroa portuguesa] e estrangeiros".

Passados alguns meses da abertura dos portos, outra medida que também contribuiria para o incremento do comércio, bem como de outras atividades a ele correlatas e, por conseguinte, para o desenvolvimento da riqueza nacional. Já do Palácio do Rio de Janeiro, depois de alguns dias da nomeação dos Ministros e Secretários de Estado ${ }^{46}$, D. João daria no mês de abril uma carta nova para o setor produtivo brasileiro e de todos os outros Domínios Ultramarinos: não só aboliu e revogou todas as ordens anteriores que impediam o florescimento das indústrias e manufaturas nessas terras - veja-se o Alvará de 5 de janeiro de 1785, por exemplo -, como chegou mesmo a incentivar a iniciativa de qualquer vassalo que viesse a multiplicar os gêneros da "agricultura e das artes"

\footnotetext{
${ }^{46}$ Cf. Decreto de 11 de março de 1808. A nomeação se deu poucos dias após a chegada da Real Coroa ao Rio de Janeiro. D. Fernando José de Portugal fora nomeado, além de Ministro e Secretário de Estado dos Negócios do Brasil e da Fazenda, Ministro Assistente ao Despacho do gabinete do Príncipe, e Presidente do Real Erário; D. Rodrigo de Souza Coutinho, o mesmo que em 1803, quando fora Ministro do Reino de Portugal, sugerira a transferência da Corte para uma de suas colônias, passou a ocupar o cargo, agora no Brasil, de Ministro e Secretário de Estado dos Negócios da Guerra e Estrangeiros; e o Visconde de Anadia, por sua vez, fora nomeado Ministro e Secretário de Estado dos Negócios da Marinha e Domínios Ultramarinos. No mesmo mês de março, outro Decreto marcava os vencimentos dos Ministros e Secretários nomeados. Ao que parece sofriam redução dos ganhos, uma vez que as rendas reais encontravam-se numa situação extraordinária. Dizia o Decreto que não mais lhes seriam permitido "vencer os mesmos ordenados que d'antes percebiam": receberiam, então, o valor de 4:800\$000 (quatro contos e oitocentos mil réis), sendo que o "Ministro e Secretário de Estado dos Negócios do Brasil [D. Fernando José de Portugal], que é também Presidente do Real erário, vencerá unicamente a dita quantia anual de 4:800\$000 por ambos os empregos que ocupa", cf. Decreto de 28 de março de 1808.

${ }^{47}$ Cf. Alvará de $1^{\circ}$ de abril de 1808 . A ordem, além da preocupação com a receita real, pois sobre os valores dos produtos melhorados e/ou dos abundantemente comercializados corresponderia um aumento proporcional à arrecadação, também se justificou pela contribuição que provavelmente daria à ocupação dos territórios por uma sociedade civilizada: é que o incremento das indústrias e manufaturas "aumentam a população dando que fazer a muitos braços e fornecendo meios de subsistência a muitos dos meus vassalos [os da Real Coroa], que por falta deles se entregariam aos vícios da ociosidade”. 'População', 'território' e 'produção' também foram termos considerados por D. Maria I quando houve "por bem ordenar que todas as Fábricas, Manufaturas, ou Teares (...) sejam extintas, e abolidas em qualquer parte onde se acharem nos Meus Domínios do Brasill”. Porém, pelo que se entende dos motivos que justificaram tal medida, num território em que a carência de braços era notória, o investimento e a dedicação às Fábricas e Manufaturas vinha provocando graves prejuízos à cultura, à lavoura e à exploração de terras minerais, o que significaria 0 desvirtuamento das possibilidades da colônia, pois "consistindo a verdadeira, e sólida riqueza nos Frutos, e Produções da Terra", elas somente existiriam "por meio de Colonos, e Cultivadores, e não de Artistas, e Fabricantes". Cf. Alvará de 5 de janeiro de 1785.
} 
Tanto a abertura dos portos à importação e exportação agora recém submetidas aos costumes do livre comércio, como a liberação dos negociantes para que se empreendessem entre Fábricas e Manufaturas, ao lado de outras medidas tomadas pelo governo logo nos primeiros anos de seu estabelecimento no Rio de Janeiro, serviram tanto aos interesses dos negociantes como aos da Real Coroa. Essa conciliação de interesses, que se propôs a promover certa intensificação no dinamismo do comércio nacional, repercutiria no proporcional aumento da arrecadação das rendas reais, pois sobre os negócios dos súditos da monarquia lusitana viriam a incidir impostos. Essas medidas, bem como a instalação da nova sede do governo, sem dúvida, trouxeram consigo transformações que remodelariam as relações mantidas entre essas classes, mas também aprofundaria outras mudanças por que passaria a região centro-sul da colônia. Se grandes negociantes, por um lado, passaram a poder traçar seu próprio itinerário ao destino de seus negócios, e não mais estariam adstritos àquele que necessariamente aportava na metrópole; por outro, e bem mais próximo à capital do governo ultramarino português, a chegada da Corte à cidade do Rio de Janeiro proporcionou, no decorrer dos anos, certa aceleração no processo de crescimento econômico e demográfico que, como vimos, vinha ganhando espaço na região desde pelo menos meados do século XVIII.

De fato, a população da cidade do Rio de Janeiro e de seu entorno havia crescido em número não só no ano de 1808, mas também durante os anos que o sucederam. Muito provavelmente devido ao estabelecimento da Família Real e de todas as pessoas que a acompanharam na viagem pelo Atlântico e, sobretudo, pelo impacto que a instalação do centro político do Império ultramarino provocaria sobre as atividades econômicas da região. Durante os anos sequentes à sua instalação, a presença da sede política do Império na capitania provavelmente atraiu para suas proximidades muitos negociantes que viam nos novos dirigentes uma oportunidade de alcançarem algum privilégio que viesse estimular e incrementar seus interesses particulares; mas certamente também colaborou para que uma economia de abastecimento se acomodasse nas adjacências da capital. Tudo isso, de um modo ou de outro, acabou por refletir no aumento do número dos que habitavam a capital, a província na qual se instalara e, em algum grau, a região centro-sul do Brasil. O conjunto de seus habitantes, no entanto, era constituído não só por pessoas livres e/ ou proprietárias, mas inclusive por escravos que, pelo menos durante a primeira metade do século XIX, seriam abundantemente traficados para a região. 


\subsection{O Café e o tráfico}

Na época em que D. João aportou na cidade do Rio de Janeiro, a produção aurífera da região das minas havia deixado seu auge nos meados do século XVIII ${ }^{48}$. Pelo menos a partir das últimas décadas deste século a região que antes conhecera a prosperidade passou, ao que parece, a acomodar uma economia de subsistência e que abasteceria de escravos e mantimentos a capital da colônia e suas adjacências. De outra região, situada ao sul das capitanias do Rio de Janeiro e de São Paulo, a Corte e as áreas próximas à capital também recebiam mantimentos destinados ao sustento de seus habitantes. Um dos destinos desses mantimentos advindos do centro e do sul do Brasil era o Vale do Paraíba, uma extensa área em torno das águas do rio Paraíba do Sul que vinha abrigando plantações de cana-deaçúcar desde as últimas décadas do setecentos. Até a década de 1820 essas plantações permitiram a extração da mercadoria que viria ocupar a primeira posição dentre os produtos brasileiros destinados ao mercado externo. $\mathrm{O}$ açúcar, isoladamente, fora responsável por cerca da terça parte das exportações brasileiras destinadas principalmente ao mercado europeu ${ }^{49}$. Mas, à medida que se aproximava a década seguinte, os canaviais fluminenses sofriam de forma mais acentuada a concorrência de outra cultura, que também necessitava de espaço para seu plantio, e de igual modo produziria uma mercadoria quase que exclusivamente destinada aos mercados estrangeiros.

Talvez o que D. João ainda não imaginasse à época de seu desembarque é que a mesma região por onde corriam as águas do rio Paraíba do Sul ofereceria as condições climáticas e o solo adequados ao cultivo daquele que viria a ser um dos principais produtos brasileiros destinados à exportação durante toda a vida política do Império, e além. Muito embora as primeiras sementes de café tenham sido plantadas em torno dos anos que rodearam o término do século XVIII, fora somente na segunda década do século XIX que a produção cafeeira do país se nivelava aos números alcançados pelas principais regiões produtoras do mundo - as situadas na América Central, como Cuba, Haiti e Jamaica; e a Indonésia. Ainda que durante quase toda a década de 1820 o preço do produto estivesse em baixa, no seu segundo lustro o Brasil pode presenciar o café despontar na segunda

\footnotetext{
${ }^{48}$ Cf. NOYA PINTO, Virgílio, Balanço das transformações econômicas no século XIX, p. 127.

${ }^{49}$ Ibidem, p. 135.
} 
colocação dentre as mercadorias que compunham o quadro das exportações nacionais, atrás somente do açúcar ${ }^{50}$. Mas esta posição logo estaria invertida.

Pelo menos durante a década seguinte e a de 1840, as regiões cafeeiras do Vale do Paraíba - que na primeira metade do século XIX se expandiam por cerca de 155 mil km² e estiveram situadas principalmente na província do Rio de Janeiro, em áreas ao nordeste da província de São Paulo e a leste da de Minas Gerais ${ }^{51}$-, beneficiadas por fatores internos e internacionais, passariam a ser responsáveis por aproximadamente $40 \%$ do total das exportações brasileiras. Tamanho volume de escoamento já fora suficiente para conferir ao café o primeiro lugar dentre as mercadorias brasileiras destinadas aos mercados estrangeiros, logo nos primeiros anos da década de 1830, e para que a produção brasileira liderasse a oferta do produto em escala mundial. E num ritmo que se manteve constante pelo menos até meados do século, o volume do açúcar exportado, produto que passara a ocupar a posição que na década anterior fora a de seu concorrente, correspondeu mais ou menos à metade do montante que os produtores de café conseguiram remeter ao exterior ${ }^{52}$.

Todos esses patamares galgados ano a ano das primeiras décadas do oitocentos revelam, sem dúvida, o destaque que a exportação do café foi adquirindo frente às exportações do açúcar, do algodão, e dos demais produtos destinados ao mercado estrangeiro. De fato, os investimentos em atividades ligadas à produção e à exportação do café trariam bons frutos ao capital empregado por proprietários e por negociantes. Mas, além disso, durante os idos do século XIX, a produção da principal mercadoria na pauta das exportações brasileiras estimularia ou mesmo incrementaria outras atividades econômicas que de alguma forma contribuíam para o progresso dos cafezais. O transporte do café das fazendas até as cidades portuárias, bem como seu armazenamento à espera da remessa aos mercados estrangeiros, e também a facilitação das formas de pagamento do produto foram algumas dentre tantas outras.

Por outro lado, tudo isso, todos esses números e todas essas montanhas construídas de sacas sobre sacas do produto acabam por nos remeter a algo além dos esforços dos proprietários quando se propuseram ao desbravamento de terras e à administração da

\footnotetext{
${ }^{50}$ Para a posição mundial da produção brasileira de café na década de 1820 , bem como um panorama dos preços pagos pelo produto no mercado mundial, cf. MARQUESE, Rafael; TOMICH, Dale, O Vale do Paraíba escravista e a formação do mercado mundial do café no século XIX, p. 349, 352, 360-361; para a posição do café no quadro das exportações brasileiras, cf. NOYA PINTO, Virgílio, op. cit., p. 135.

${ }^{51}$ Cf. MARQUESE, Rafael; TOMICH, Dale, op. cit., p. 341-342; cf. MELLO, Pedro Carvalho de, Aspectos econômicos da organização do trabalho da economia cafeeira do Rio de Janeiro, 1850-88, p. 30.

${ }^{52}$ Para a posição mundial da produção brasileira de café na década de 1830 e seguintes, cf. MARQUESE, Rafael; TOMICH, Dale, op. cit., p. 360-361; para a primazia do café dentre os produtos brasileiros destinados à exportação até a metade do século XIX, cf. NOYA PINTO, Virgílio, op. cit., p. 135.
} 
produção cafeeira. Os cafezais vislumbram um dos principais fatores que contribuíram para toda essa prosperidade da região centro-sul do país. Por entre as suas fileiras que cortavam os morros plantados operava a mão de obra que colhia os grãos maduros, que os preparavam para a secagem, depois para a moagem e, posteriormente, davam destino à mercadoria. Pelo menos durante a primeira metade do século XIX o braço escravo foi a força de trabalho intensamente empregada nas fazendas produtoras de café.

O escravo fora fator extremamente necessário à sobrevivência da produção cafeeira, bem como do plantio das demais culturas destinadas ao mercado externo. Em épocas de vultoso aumento da demanda internacional por algum produto, como conhecera o café desde fins da década de 1820 até pelo menos meados do século, a intensificação da produção, ou mesmo sua expansão para áreas recém desbravadas, exigiu a elevação da quantidade de cativos até então empregada nas plantações. Era inevitável que a maior ou menor disponibilidade do braço africano no mercado, ou mesmo as condições em que estavam disponíveis, concorreria, em algum grau, para o atraso ou para o desenvolvimento dos empreendimentos agroexportadores que, mesmo em períodos de estabilidade da produção, constantemente necessitavam de reposição da mão de obra que trabalhava nas lavouras. A aquisição de cativos, como se vê, tornou-se preocupação constante para a manutenção da prosperidade dos cafezais.

Ao que tudo indica, os proprietários buscaram a reposição da força de trabalho, ou mesmo a elevação de sua quantidade, por meios que descartassem a esperança que porventura fora depositada sobre o crescimento vegetativo de sua escravaria. Tratava-se de uma população cuja tendência era diminuir, em números absolutos, no decorrer dos anos. A baixa taxa de natalidade e a alta mortalidade presente entre seus membros bem poderiam ser explicadas pelas péssimas condições nutricionais ou sanitárias a que estavam constrangidos. Mas, a este efeito negativo é somada a predisposição dos proprietários de intensificar a exploração do trabalho escravo nas épocas em que o mercado externo demandava maior quantidade do produto, ou mesmo durante os períodos em que era evidente a facilidade com que se repunha o braço perdido ${ }^{53}$. De todo modo, essa insuficiência da auto-reposição, ao menos a que tangia os números demandados para a manutenção da produção cafeeira, seria logo resolvida pela aquisição de cativos provenientes de uma fonte externa à propriedade.

\footnotetext{
${ }^{53}$ Cf. FLORENTINO, Manolo, op. cit., p. 31-33, 50-60.
} 
Pelo menos durante a primeira metade do século XIX, os novos escravos que chegavam às plantações provinham, majoritariamente, do continente africano. Eram os boçais, como eram denominados os cativos recém introduzidos no país, ao contrário dos ladinos, que por aqui já residiam havia certo tempo. O tráfico transatlântico acabou por suprir a carência sempre presente, e em não raros momentos sempre crescente, da mão de obra escrava tão visada pelos proprietários. Uma vez desembarcados pelos negreiros, que invariavelmente aportavam nas águas costeiras da província do Rio de Janeiro, os escravos eram encaminhados daí às fazendas produtoras. Nos primeiros trinta anos desse mesmo século, o porto do Rio de Janeiro fora responsável pelo abastecimento de propriedades situadas no Sul e Sudeste do Brasil. Dali os cativos eram distribuídos, em geral, para pelo menos três grandes centros que absorviam essa força de trabalho: um deles fora Campos dos Goytacazes e seus arredores que, à época da chegada da Corte à província, ainda investia na produção açucareira, embora também se dedicasse às atividades relacionadas ao abastecimento da região; a cidade do Rio de Janeiro e suas adjacências formavam a praça mercantil da província e, em decorrência de sua dinâmica comercial, também necessitavam de escravos; por último, e já mencionada, a região do vale do rio Paraíba do $\mathrm{Sul}^{54}$, cuja produção de café estaria em contínua expansão, sendo o grão nacional um dos mais procurados pelos mercados consumidores da Europa e da América do Norte, o que suceder-se-ia aos anos finais do Império do Brasil.

O porto do Rio de Janeiro presenciou, de fato, o desembarque de um enorme contingente de cativos recém trazidos da África. Sua importância para a história do tráfico transatlântico também se revela por ter servido ao maior fluxo negreiro do mundo, como o fora o tráfico carioca desde a última década do século XVIII até cerca de $1830^{55}$. Boa parte de todos esses braços africanos seria destinado ao suprimento da expansão da produção cafeeira. Tanto a demanda proveniente das propriedades situadas em terras fluminenses e paulistas do Vale do Paraíba, como a demanda das fazendas localizadas no lado leste da província de Minas Gerais, foram fatores relevantes para o incremento do negócio negreiro $^{56}$ durante a primeira metade do século XIX. Durante estes anos todos, esse negócio empreendido principalmente por traficantes brasileiros, ou portugueses estabelecidos no país, seria pautado por uma disputa de forças travada entre os grossos

\footnotetext{
${ }^{54}$ Ibidem, p. 37-40.

${ }^{55}$ Ibidem, p. 11, 64-66.

${ }^{56}$ Cf. MARQUESE, Rafael de Bivar, A dinâmica da escravidão no Brasil, p. 121-122; cf. PARRON, Tâmis Peixoto, A política da escravidão no Império do Brasil, 1826-1865, p. 05.
} 
interesses nele envolvidos, e no final das contas sua marcha esteve condicionada às cartas postas em jogo por qualquer uma das partes que tinham algo a proteger.

Mas, apesar da conjuntura político-econômica da primeira metade do oitocentos, em que paulatinamente ia se tornando mais notória a pressão internacional pelo fim do tráfico transatlântico, os anos que se seguiram à chegada da Corte portuguesa ao Rio de Janeiro, e que se estenderam até 1850, apontaram para a consistência do tráfico negreiro. Em apenas quarenta anos algo em torno de 1,4 milhão de escravos desembarcaram, legal ou clandestinamente, em águas territoriais brasileiras. Ou, em termos relativos, o equivalente a cerca de $40 \%$ de todos os escravos entrados no Brasil nos três séculos de sua história $^{57}$. Em determinados momentos, a introdução de cativos africanos fora mais intensa que em outras ocasiões, a depender das circunstâncias sobre as quais o negócio deveria ser planejado. Por volta de 1810, por exemplo, à época em que a Corte estabelecida no Rio de Janeiro deu ordens para que se abrissem os portos ao comércio internacional rompendo, assim, com a tradicional relação exclusivista que a colônia mantinha com Portugal, uma quantidade extraordinária de navios negreiros aportou em águas brasileiras. Todas essas entradas devem ter ocasionado a saturação do mercado interno num período imediatamente posterior, e podem explicar o enfraquecimento do negócio em torno no quadriênio 18121815. Tendo já se recuperado da queda que o acometera no decênio anterior, os desembarques decorrentes do tráfico transatlântico recrudesceriam durante o quinquênio que se iniciaria em 1825. Os anos sequentes a esse período presenciaram certa suavização dos negócios negreiros, então considerado ilegal, mas seu volume estaria recuperado logo no segundo lustro da década de 1830.

Os últimos anos da década de 1820 foram os que proporcionaram as maiores entradas de escravos no porto do Rio de Janeiro, e, ao que tudo indica, em grande número eles foram distribuídos para as regiões cafeeiras do Vale do Paraíba. Os cafezais poderiam muito bem ter absorvido uma quantidade razoável dos cerca de cem mil cativos desembarcados na província, pois, cinco anos mais tarde, quando as mudas plantadas durante os anos de 1828 e 1829 começaram a dar frutos, o Brasil acabara de se tornar o maior produtor mundial de café e $^{58}$. O café dependia do escravo, e o escravo provinha do tráfico.

\footnotetext{
${ }^{57}$ Cf. MARQUESE, Rafael de Bivar, A dinâmica da escravidão no Brasil, p. 121-122.

${ }^{58}$ Cf. MARQUESE, Rafael; TOMICH, Dale, O Vale do Paraíba escravista e a formação do mercado mundial do café no século XIX, p. 365.
} 
Provavelmente qualquer abalo nesse mercado transatlântico viria a repercutir na estrutura da produção cafeeira: não só na administração das plantações, como também no próprio trato com o escravo. A quantidade de cativos, e mesmo o preço a que estavam disponíveis no mercado de mão de obra escravizada, tornaram-se variáveis que deveriam ser levadas em consideração pelos proprietários cafeicultores quando da administração de seus empreendimentos agrícolas. Do início até meados do século XIX, o tráfico negreiro sofreria intensa perseguição - nacional mas, sobretudo, internacional - e daria seus últimos suspiros no correr da década de 1850. Principalmente durante a segunda metade dos anos de 1840, o volume de cativos africanos introduzidos no país esteve adstrito não só ao número de viagens empreendidas à costa africana, mas, sobretudo à conjuntura internacional que, coincidentemente desde a primeira década do século XIX, vinha remodelando o mundo pelas transformações nos alicerces das tradicionais sociedades escravistas coloniais ${ }^{59}$. O sucesso ou insucesso do tráfico negreiro, portanto, estaria à mercê também de outros fatores, internos ou externos, nem tanto de ordem estritamente econômica, mas sobretudo de interesses que seriam negociados numa esfera política, ou caso queira, diplomática.

\subsection{O Tráfico e os seguros}

No mês de outubro de 1807, enquanto o Conselho de Estado português marcava constantes reuniões para decidir os rumos que deveria tomar o Governo caso se concretizassem as previsíveis investidas napoleônicas sobre o território lusitano, pareceu ter ficado claro a Portugal que, se a Corte optasse por deixar a Europa e se estabelecesse na sua colônia americana, a dívida a ser paga aos britânicos pela escolta que prestaria à Família Real durante o traslado atlântico, e também pela proteção que vinha garantindo a integridade dos territórios de seu Império ultramarino, exigiria mais do que a abertura do mercado brasileiro aos produtos provenientes da Ilha. Em tempos de instabilidade da ordem europeia, que vinha impondo obstáculos à circulação das mercadorias da Grã-

\footnotetext{
${ }^{59}$ Para um quadro geral das tendências do volume de cativos africanos introduzidos no Brasil na primeira metade do século XIX, cf. MARQUESE, Rafael de Bivar. A Administração do Trabalho Escravo nos Manuais de Fazendeiro do Brasil Império, 1830-1847, p. 105; cf. FLORENTINO, Manolo, op. cit., p. 46-47. Manolo Florentino ainda sugere que a média anual de navios negreiros que chegaram da África no período compreendido entre 1809 a 1825 foi maior que a média verificada para os anos 1796-1808. Uma forma, como se vê, de reafirmar o impacto que a instalação da Corte portuguesa na província do Rio de Janeiro proporcionou ao incremento do tráfico transatlântico de escravos.
} 
Bretanha no Velho Continente, os portugueses não só concordariam em privilegiar a importação dos manufaturados britânicos para o Brasil, como também cederiam às primeiras pressões dos interesses abolicionistas que a senhora dos mares viria demonstrar durante quase todo o século $\mathrm{XIX}^{60}$.

No dia 25 de março do mesmo ano de 1807, apenas alguns meses antes dos Bragança deixarem Portugal rumo ao Brasil, a Grã-Bretanha proibira o tráfico transatlântico de escravos realizado sob sua bandeira. Porém, a validade dessa ordem que afetou diretamente os interesses dos súditos britânicos, que na primeira década do oitocentos dominavam cerca da metade do negócio negreiro, somente estaria prevista para o dia $1^{\circ}$ de maio de 1808 . Por essa época poucas nações já teriam se manifestado favoravelmente à abolição do tráfico, e algumas vozes da sociedade civil britânica já teriam se levantado exprimindo o desejo de que essa regra passasse a valer para outros países. Além dos argumentos de ordem moral, que pregavam a desumanidade do tráfico negreiro, havia aqueles que transitavam principalmente pela esfera político-econômica. Talvez o caso das Antilhas seja exemplar. Eram territórios pertencentes ao Império britânico - Império de caráter quase que exclusivamente agroindustrial e que em meados do século XIX fora de "escala e alcance sem precedentes e sem paralelo" (ARRIGHI, 1996, p. 180) -, e como grandes produtoras de açúcar destinado essencialmente à exportação, perdiam o principal meio de reposição da força de trabalho nas suas lavouras. O tráfico permitia que a mão de obra fosse adquirida a preços relativamente baixos, o que colocava em desvantagem os canaviais antilhanos frente às produções que lhes eram concorrentes, como a cubana e a brasileira ${ }^{61}$.

Além do mais, se a intenção fosse mesmo a de transformar a África em mais um mercado consumidor dos seus produtos manufaturados, talvez fosse o momento apropriado para a Grã-Bretanha se dedicar à extinção do tráfico, e por conseguinte da escravidão, pois, uma vez saturadas as possibilidades do seu mercado interno converter os capitais investidos na produção em lucros interessantes aos capitalistas, não tardaria muito até que a senhora dos mares tivesse de desbravar novos mercados que porventura dessem conta de consumir suas mercadorias, em especial as de bens de capital, pautando, assim, o ritmo da expansão do comércio mundial que ganhou terreno em meados do oitocentos ${ }^{62}$.

\footnotetext{
${ }^{60}$ Cf. BETHELL, Leslie, A abolição do tráfico de escravos no Brasil, p. 21.

${ }^{61}$ Cf. BETHELL, Leslie, op. cit., p. 07-08; cf. ARRIGHI, Giovanni, op. cit., p. 180.

${ }^{62}$ Cf. BETHELL, Leslie, op. cit., p. 08; cf. ARRIGHI, Giovanni, op. cit., p. 165, 179-180.
} 
Se fosse este o verdadeiro intento dos britânicos, muito ainda estaria por ser feito num mundo que começava a romper os grilhões coloniais. Os ventos soprados do Continente iriam remodelar as tradicionais relações político-econômicas que mantinham erguidos os seculares impérios ultramarinos europeus - sobretudo, os de Portugal e Espanha. Ao que parece, a Grã-Bretanha soube aproveitar todas as oportunidades que o século XIX lhe proporcionou. Na Europa do início do século, tirou vantagem da instabilidade e fraqueza política que acometia as demais potências para obter a assinatura de tratados anti-tráfico. Na América, os pedidos de reconhecimento político que os Estados recém constituídos pleiteariam para suas independências recém conquistadas estariam condicionados ao compromisso de abolirem o tráfico transatlântico de escravos para seus territórios $^{63}$. Umas e outras estratégias, se não deram conta de extinguir o tráfico rapidamente, ou tão rápido quanto o desejo britânico de dissipá-lo, aos poucos o foram golpeando até que desfalecesse, e se acabasse. De qualquer modo, a intensa perseguição britânica aos negreiros foi fazendo do comércio transatlântico de escravos um negócio cada vez mais arriscado, mais perigos eram somados a um empreendimento que por si só já era repleto de riscos.

Portugal não escapou à regra. Passados quase dois anos da instalação da Corte na cidade do Rio de Janeiro, Lord Strangford, então embaixador inglês em Lisboa, e que chegara ao Brasil no mesmo comboio em que viajara a Família Real, convencera o príncipe regente D. João a firmar dois tratados a benefício das relações mantidas entre as duas nações. O primeiro, o Tratado de Comércio e Navegação, acabou sendo-lhes muito favorável, pois, por ele, além de se conhecer a presença dos juízes conservadores da nação britânica em território lusitano, que passariam a decidir as questões envolvendo os súditos de Jorge III, a tarifa máxima a incidir sobre os produtos importados pela colônia portuguesa não chegaria a ultrapassar os $15 \%$, montante inferior ao que o governo português impusera às transações com as demais nações marítimas, e que muito provavelmente incentivaria a preferência, dentre os nacionais, pelas mercadorias inglesas. O segundo, o Tratado de Aliança e Amizade, também assinado no dia 19 de fevereiro de 1810, viria bater ás portas de Portugal e pedir-lhe um aceno que seja, em direção ao compromisso de se abolir o tráfico transatlântico de escravos, ainda que de maneira gradual. Em nome de uma amizade desinteressada, portanto, o décimo artigo do Tratado denuncia que D. João concedeu em proibir que seus vassalos continuassem a comercializar

\footnotetext{
${ }^{63}$ Cf. PARRON, Tâmis Peixoto, op. cit., p. 21-22.
} 
cativos "em outra alguma parte da Costa da África, que não pertença atualmente aos Domínios de Sua Alteza Real, nos quais este Comércio foi já descontinuado e abandonado pelas Potências e Estados da Europa, que antigamente ali comerciavam"64.

Contudo - e pelo que não esperariam os comerciantes de escravos estabelecidos nas praças da Bahia, do Maranhão, do Rio de Janeiro, e do Recife -, uma interpretação errônea do acordo registrado pelo artigo $\mathrm{X}$ do Tratado levou a armada britânica a capturar inúmeros negreiros que estariam em trânsito ao norte da linha do equador ${ }^{65}$. Tal foram os casos, por exemplo, da escuna Paquete Volante e a galera Urbano, ambos capturados em agosto de 1811; em janeiro de 1812 foram apreendidos o brigue Dezengano e o bergantim Lindeza e, três meses depois, o brigue Bom Caminho; no ano seguinte, chegara a vez do bergantim Desforço, capturado em agosto; o bergantim Destino foi apreendido em janeiro de 1814 e, em maio desse mesmo ano, a galera Nossa Senhora da Victoria. Ano a ano as embarcações continuariam a sofrer as perseguições por parte da senhora dos mares e, até que a situação fosse normalizada, muitos prejuízos já teriam sido causados ao comércio. Aumentara o número de processos ajuizados contra as companhias de seguros brasileiras Indemnidade, Previdente, Permanente, Restauradora, Boa Fé e Segurança que, assim como outras tantas companhias seguradoras portuguesas e inglesas, deixaram de indenizar as perdas dos seus segurados. Pelo menos até 1818 , as praças comerciais das províncias da

\footnotetext{
${ }^{64}$ As informações a respeito do processo de negociação que acabou por levar o Império do Brasil à proibição do tráfico negreiro foram proporcionadas principalmente pela obra BETHELL, Leslie, A Abolição do tráfico de escravos no Brasil (especialmente páginas 21-22; 24; 26; 30-31; 39-40; 41; 53; 59-60; 62; 69; 70; 93; 9596; 204-205; 227; 244-245; 253; 268-269; 321; 322; 343). Ela, e também o que informou PARRON, Tâmis, A política da escravidão no Império do Brasil, 1826-1865; e RODRIGUES, Jaime, O Infame comércio, todas elas contribuíram para a composição da narrativa que toma lugar neste e nos parágrafos seguintes.

${ }^{65} \mathrm{O}$ texto completo do artigo X do Tratado de Aliança e Amizade compactuado pelas Coroas portuguesa e britânica dizia o seguinte: "Sua Alteza Real o Príncipe Regente de Portugal estando plenamente convencido da Injustiça, e má Política do Comércio de Escravos, e da grande desvantagem que nasce da necessidade de introduzir, e continuamente renovar uma Estranha, e Factícia População para entreter o Trabalho e Indústria nos Seus Domínios do Sul da América, tem resolvido de cooperar com Sua Majestade Britânica na Causa da Humanidade e Justiça, adotando os mais eficazes meios para conseguir em toda a extensão dos Seus Domínios uma gradual abolição do Comércio de Escravos. E movido por este Princípio Sua Alteza Real o Príncipe Regente de Portugal Se obriga a que aos Seus Vassalos não será permitido continuar o Comércio de Escravos em outra alguma parte da Costa da África, que não pertença atualmente aos Domínios de Sua Alteza Real, nos quais este Comércio foi já descontinuado e abandonado pelas Potências e Estados da Europa, que antigamente ali comerciavam; reservando contudo para os Seus Próprios Vassalos o direito de comprar e negociar em Escravos nos Domínios Africanos da Coroa de Portugal. Deve porém ficar distintamente entendido, que as Estipulações do Presente Artigo não serão consideradas como invalidando, ou afetando de modo algum os Direitos da Coroa de Portugal aos Territórios de Cabinda e Molembo, os quais Direitos foram em outro tempo disputados pelo Governo de França, nem como limitando ou restringindo o Comércio de Ajuda, e outros Portos d'África (situados sobre a Costa comumente chamada na Língua Portuguesa a Costa da Mina), e que pertencem, ou a que tem pretensões a Coroa de Portugal. Estando Sua Alteza Real o Príncipe Regente de Portugal resolvido a não resignar, nem deixar perder as Suas justas, e legítimas Pretensões aos mesmos, nem os Direitos de Seus Vassalos de negociar com estes Lugares, exatamente pela mesma maneira que eles até aqui o praticavam.", cf. Carta de Lei de 26 de fevereiro de 1810.
} 
Bahia, de Pernambuco e do Rio de Janeiro presenciariam a falência de seguradoras, de casas comerciais - inclusive filiais britânicas -, e de particulares que, como membros de uma sociedade escravista, investiram seus cabedais, ou parte deles, no comércio negreiro ${ }^{66}$.

A Grã-Bretanha demoraria cerca de cinco anos para se retratar, e só o fez na ocasião do Congresso de Viena, quando dois novos tratados foram firmados com a Coroa portuguesa. Pelo primeiro deles, assinado no dia 21 de janeiro de 1815, ficou estipulado que 300 mil libras seria o valor a ser indenizado pelas apreensões ilegais ocorridas até o dia $1^{\circ}$ de junho de 1814. Além disso, conforme denuncia o segundo Tratado, este assinado no dia seguinte (22 de janeiro de 1815), os britânicos perdoariam o pagamento do montante que ainda lhes seria devido por Portugal em decorrência de um empréstimo de 600 mil libras tomado em 1809 e, em troca, D. João se comprometeria a declarar ilegal o tráfico negreiro praticado por seus vassalos ao norte do equador, ao mesmo tempo em que se prontificaria a dar continuidade ao compromisso firmado anos antes, qual seja o de se ater à abolição gradual do comércio transatlântico de escravos realizado sob a bandeira lusitana. Longe ainda de alcançar seus objetivos, não tardaria muito até que a Grã-Bretanha recomeçasse a pressionar Portugal para que se alinhasse ao lado das nações abolicionistas.

De fato, passados pouco mais de dois anos dos últimos compromissos firmados, o Conde de Palmella, então embaixador português em Londres, assinou a Convenção Adicional ao Tratado de 22 de janeiro de 1815, no dia 28 de julho de 1817. Na prática, os termos dessa Convenção significariam a concessão de mais poderes à atuação da armada britânica principalmente no Atlântico, pois, assim como os navios de guerra portugueses, estaria autorizada a vistoriar embarcações suspeitas de comercializarem escravos provenientes das regiões da costa africana que, em decorrência da assinatura dos Tratados de 1810 e de 1815, foram colocadas à margem do jogo negreiro. E, se pelas vistorias fossem encontrados cativos a bordo, cujos destinos muito provavelmente desaguariam nas terras do continente americano, estas embarcações seriam legalmente apreendidas e levadas a julgamento em uma das comissões mistas instaladas uma, a britânica, na África Ocidental, e a outra, a portuguesa, no Brasil. Os que fossem condenados por qualquer uma das comissões seriam encaminhados aos mandos das autoridades dos seus respectivos países de origem. Se britânicos, às autoridades britânicas; se lusitanos, às autoridades

\footnotetext{
${ }^{66}$ Cf. TAVARES, Luís Henrique Dias, O Capitalismo no comércio proibido de escravos, p. 38; 39; 40; 41; 43; cf. TAVARES, Luís Henrique Dias, Comércio proibido de escravos, p. 16-17; 19; 20; $23-24$. Especificamente sobre o número de negreiros apreendidos após a assinatura do Tratado de Aliança e Amizade, nos dois anos que se seguiram a 1810 "17 navios foram capturados pela marinha inglesa", cf. RODRIGUES, Jaime, op. cit., p. 97.
} 
portuguesas, estas tão afins ao comércio transatlântico de escravos que dificilmente se poderia acreditar que puniriam os proprietários das embarcações, bem como os capitães ou a equipagem dos navios envolvidos no tráfico ilegal.

Quando em setembro de 1822 D. Pedro I proclamou a Independência e fundou o primeiro império brasileiro, os britânicos entenderam que todo esse desenrolar com Portugal estaria resolvido de uma vez por todas. De fato, o governo português vinha insistentemente se utilizando da mesma desculpa para não ceder às pressões que o fariam abolir totalmente o tráfico transatlântico praticado sob sua bandeira. E então, uma vez que sua colônia americana deixaria de ser parte do Império Ultramarino lusitano, o artigo quarto do Tratado de 22 de janeiro $1815^{67}$ - pelo qual D. João concordara em manter o tráfico somente para os fins do abastecimento de suas possessões transatlânticas com a força de trabalho africana -, e o artigo primeiro da Convenção Adicional de 28 de julho de $1817^{68}$ - que tornara ilícito o tráfico praticado por "Navios Portugueses que se destinassem para um Porto qualquer fora dos Domínios de SUA MAGESTADE FIDELÍSSIMA"; ambos os dispositivos, combinados, acabavam por estabelecer o fim absoluto da participação portuguesa no infame comércio. Pelo menos essa seria a interpretação dos britânicos que, se por um lado conseguiam algum novo argumento para as futuras negociações com Portugal, por outro, estariam apreensivos com algumas mudanças recém ocorridas no jogo das nações.

De fato, a Independência do Brasil fora motivo de preocupações para a GrãBretanha, principalmente porque esse novo evento político poderia dar novos rumos às negociações em torno da proibição total do tráfico de escravos, que tanto ambicionava. A

\footnotetext{
${ }^{67} \mathrm{O}$ texto completo do referido artigo quarto do Tratado assinado no dia 22 de janeiro de 1815 dizia o seguinte: “As Duas Altas Partes Contratantes Se Reservam, e Obrigam a fixar por um Tratado separado o período em que o Comércio de Escravos haja de cessar universalmente, e de ser proibido em todos os Domínios de Portugal: e Sua Alteza Real O Príncipe Regente de Portugal Renova aqui a Sua anterior Declaração e Ajuste de que, no intervalo que decorrer até a sobredita abolição geral e final se verifique, não será lícito aos Vassalos Portugueses o comprarem ou traficarem em Escravos em qualquer parte da Costa de África, que na seja ao Sul da Linha Equinocial, como fica especificado no segundo Artigo deste Tratado; nem tampouco o empreenderem este Tráfico debaixo da Bandeira Portuguesa para outro fim que não seja o de suprir de Escravos as Possessões Transatlânticas da Coroa de Portugal”.

68 “O objeto desta Convenção é, por parte de Ambos os Governos, vigiar mutuamente que os Seus Vassalos Respectivos não façam o Comércio ilícito de Escravos. As DUAS ALTAS PARTES CONTRATANTES Declaram, que Elas consideram como Tráfico ilícito de Escravos, o que, para o futuro, houvesse de se fazer em tais circunstâncias como as seguintes, a saber: $1^{\circ}$ Em Navios e debaixo de Bandeira Britânica, ou por conta de Vassalos Britânicos em qualquer Navio, ou debaixo de qualquer bandeira que seja. $2^{\circ}$ Em Navios Portugueses em todos os Portos ou Paragens da Costa d'África que se acham proibidas em virtude do Artigo $1^{\circ}$ do Tratado de vinte e dois de Janeiro de mil oitocentos e quinze. $3^{\circ}$ Debaixo da Bandeira Portuguesa ou Britânica, quando por conta de Vassalos de outra Potência. $4^{\circ}$ Por Navios Portugueses que se destinassem por um Porto qualquer fora dos Domínios de SUA MAGESTADE FIDELÍSSIMA.”, cf. Convenção Adicional ao Tratado de 22 de janeiro de 1815.
} 
situação tornar-se-ia ainda mais inquietante ao se conhecer que a parcela de participação reservada ao Brasil neste comércio muito provavelmente sobressaía à que estivera adstrito Portugal, ou mesmo qualquer outra nação marítima. A ex-colônia portuguesa na América seria o principal mercado comprador de cativos africanos do mundo e, como agravante às circunstâncias, a sua tenra idade fizera com que ainda não estivesse impedida à realização deste negócio, pelo menos não legalmente.

Tudo isso convencera as potências de que a imposição de algumas condições seria indispensável ao reconhecimento que a jovem nação tão logo pleitearia para legitimar sua independência e soberania diante do cenário político mundial das primeiras décadas do século XIX. As negociações com Portugal, por exemplo, não seriam postas a termo se D. Pedro I não se comprometesse a rejeitar qualquer possibilidade de aumentar o território brasileiro às custas de incorporações de colônias portuguesas situadas no continente africano, ou mesmo de se associar a elas. Pois, como parece, se ocorresse a separação de Angola, por exemplo, então uma das principais regiões exportadoras de escravos para o Novo Mundo, as transações negreiras que mantinha com traficantes estabelecidos no Brasil novamente entrariam para a legalidade e as embarcações que dali partissem não mais estariam submetidas às investidas da armada britânica. Uma vez combinados, Portugal reconheceu a independência de sua ex-colônia pelo Tratado assinado no dia 29 de agosto de 1825 , cerca de um ano antes que a Grã-Bretanha.

A senhora dos mares reconheceria a independência do Brasil em 23 de novembro de 1826, por um Tratado que estipularia o prazo de três anos, a contar da data de sua ratificação, a partir do qual, de acordo com o que ia no primeiro artigo deste documento, seria considerado pirataria o tráfico de escravos praticado por qualquer negociante brasileiro $^{69}$. A ratificação pela Coroa britânica ocorreu no ano seguinte, no dia 13 de março, alguns meses antes de outro Tratado assinado no dia 17 de agosto de 1827, cujos fins seriam principalmente comerciais, manter o valor da tarifa que já vinha incidindo sobre os produtos ingleses importados pela ex-colônia (15\%), e acordar pela permanência dos juízes conservadores em território brasileiro.

Quando chegou o 13 de março de 1830, dia em que passaria a valer as novas regras compactuadas pelas duas nações, a Grã-Bretanha se viu às voltas com inúmeras dúvidas

\footnotetext{
${ }^{69} \mathrm{O}$ artigo $1^{\circ}$ do Tratado de 23 de novembro de 1826, ratificado pela Grã-Bretanha em 1827, foi composto da seguinte forma: “Acabados três anos depois da troca de ratificações do presente Tratado, não será lícito aos súditos do Império do Brasil fazer o comércio de escravos na Costa d'África, debaixo de qualquer pretexto, ou maneira qualquer que seja. E a continuação deste comércio, feito depois da dita época, por qualquer pessoa súdita de Sua Majestade imperial, será considerado e tratado de pirataria".
} 
provenientes da interpretação do Tratado de 1826, e principalmente do teor de seu primeiro artigo. Os limites à atuação da armada britânica no Atlântico deveriam ser postos em termos muito bem esclarecidos, pois assim evitar-se-ia que qualquer ato praticado contra as embarcações negreiras se configurasse numa afronta ao direito internacional. De fato, as lacunas em torno de quem seria competente para abordar, revistar e apreender os negreiros dos súditos brasileiros; dos locais permitidos à referida abordagem; da possibilidade ou não de se empreender a captura de embarcações sem que escravos estivessem sendo transportados de uma costa a outra do oceano; da legitimidade dos tribunais britânicos para julgarem os envolvidos no tráfico ilegal; todas essas questões, se não respondidas, só colocariam mais empecilhos à perseguição dos navios usados no comércio transatlântico de escravos e, por conseguinte, à abolição deste negócio tão prejudicial aos anseios da GrãBretanha.

Durante os anos que se seguiram ao início da vigência do Tratado, os britânicos continuaram a pressionar o governo brasileiro para que este concordasse em ampliar os poderes concedidos à sua armada que, costumeiramente, já vinha exercendo a fiscalização sobre os vasos negreiros em trânsito pelo Atlântico. Mesmo com a aprovação da Lei de 7 de novembro de 1831 pelo Legislativo brasileiro $^{70}$, cujo primeiro artigo declarara livre “Todos os escravos, que entrarem no território ou portos do Brasil, vindos de fora", o número de cativos importados via contrabando não deu sinais de que iria diminuir tão cedo, talvez porque a conjuntura econômica mundial estivera oportuna ao recrudescimento da produção cafeeira - o mercado norte americano estivera propício a comprar muitas toneladas do café produzido no Brasil, em detrimento do grão cubano, então sobretaxado em decorrência dos desentendimentos travados com a Espanha -, o que só faria aumentar a necessidade de importação de mais braços africanos para o trabalho nas lavouras. Diante desse quadro, qualquer pressão vinda de fora, ou qualquer tentativa por parte dos agentes do governo de suprimir o tráfico ilegal de escravos esbarrariam nas resistências impostas pela própria sociedade brasileira e por seus deputados nas assembleias provinciais e Geral que, liderados dentre outros por Bernardo Pereira de Vasconcelos, aproveitavam-se do impacto negativo que a Lei de 1831 tivera entre os proprietários para garantirem sucessivas eleições ao parlamento. Foram conhecidos como o Regresso, e por eles dificilmente

\footnotetext{
${ }^{70}$ A aprovação da lei de 1831 bem poderia ser interpretada como a concretização do desejo da Assembleia Geral em ratificar os compromissos já assumidos pelo país no exterior, mas, além disso, como a manifestação de sua preeminência frente ao Poder Executivo que, como era sabido, assinara o Tratado de 1826 por sua própria iniciativa. Cf. MARQUESE, Rafael de Bivar; PARRON, Tâmis Peixoto, Azeredo Coutinho, Visconde de Araruama e a Memória sobre o Comércio dos Escravos de 1838, p. 109.
} 
passariam quaisquer reformas que porventura fossem de encontro aos interesses negreiros ${ }^{71}$.

Mas a Grã-Bretanha não desistiria enquanto não conseguisse eliminar por completo a prática do tráfico de escravos, e as pressões sobre o governo brasileiro seriam cada vez mais intensas à medida que ia entrando os anos de 1840. Também fora no primeiro lustro da década que o governo britânico se viu obrigado a interpretar o sentido de todos os tratados e convenções compactuados com o Brasil, e agir de acordo com esta interpretação, pois, conforme correra o tempo, o Tratado de 1817 expiraria em 1845 e, então, ou a GrãBretanha defenderia que o primeiro artigo do Tratado de 1826 lhe concedera poderes suficientes para que tratasse o tráfico brasileiro como pirataria, ou, caso contrário, assistiria o recrudescimento deste comércio sem que nada fizesse para detê-lo. De nada adiantaria os agentes do governo brasileiro reclamarem das inobservâncias dos tratados e das regras do direito internacional, das investidas contrárias ao direito de um país independente exercer a soberania sobre a totalidade de seu território, das capturas que a armada britânica vinha realizando mesmo em águas territoriais brasileiras somente baseadas na suspeita de que o navio teria servido aos fins do tráfico ilegal, ou dos julgamentos das presas por tribunais britânicos; nada disso impediria a promulgação do Bill Aberdeen no dia 8 de agosto de 1845, ato pelo qual a Grã-Bretanha se arrogava o direito de dar um fim, por seus próprios meios, ao comércio transatlântico de escravos praticado pelos súditos do Império do Brasil, já que este se mostrou incapaz de fazê-lo ${ }^{72}$.

${ }^{71}$ Bernardo Pereira de Vasconcelos nasceu no dia 27 de agosto de 1795, em Vila Rica, depois Ouro Preto. Em 1813 matriculou-se na Universidade de Coimbra, onde bacharelou-se em Direito no ano de 1818. Em retorno ao Brasil, ocupou o cargo de Juiz de Fora de Guaratinguetá e, mais tarde, o de Desembargador da Relação do Maranhão. Foi eleito Deputado à Assembleia Geral representando sua província natal (Minas Gerais) em 1826, e aí permaneceria te ser eleito Senador, em 1838. Foi nomeado Ministro da Fazenda (1831), da Justiça (1837), e do Império (1840), além de ter sido Conselheiro de Estado. Teve grande participação na elaboração do Código Criminal do Brasil (1830), e também muito colaborou na feitura do Código de Processo (1832) e na Reforma do Ato Adicional (1834). Bernardo Pereira de Vasconcelos faleceu na Corte, vítima de febre amarela, no dia $1^{\circ}$ de maio de 1850. Cf. BLAKE, Augusto Victorino Alves Sacramento, Diccionário Bibliographico Brasileiro, vol. 1, p. 415-416. Para um aprofundamento acerca do Regresso, bem como das articulações de boa parte da sociedade civil pela reforma da Lei de 1831, cf. MARQUESE, Rafael de Bivar; PARRON, Tâmis Peixoto, op. cit., p. 109-112; PARRON, Tâmis Peixoto, A política da escravidão no Império do Brasil, 1826-1865.

72 A Grã-Bretanha de igual modo vinha compactuando com outras nações o fim do tráfico negreiro. A Espanha, por exemplo, no dia 23 de setembro de 1817 abolira o tráfico negreiro, realizado sob sua bandeira e ao norte do equador, em troca de 400 mil libras; alguns anos mais tarde, em maio de 1820, além de desautorizar este comércio ao sul do equador, concedia à armada britânica o direito de vistoriar, buscar e deter os navios espanhois suspeitos de participarem do tráfico ilegal. A Holanda, no dia 4 de maio de 1818, assina uma convenção com a Grã-Bretanha que de igual modo conceder-lhe-ia o direito de busca. Durante os anos de 1822 e 1823, tanto Portugal, como a Espanha e a Holanda, cada um a seu tempo, acabaram por ceder às pressões britânicas e concordaram que as embarcações que transitavam o Atlântico sob suas respectivas bandeiras poderiam ser apreendidas caso não restassem dúvidas que escravos estiveram a bordo em algum momento da viagem. Por outro lado, nesse mesmo período, nem os Estados Unidos e nem a França cederiam 
Em pouco tempo o número de negreiros aprisionados e enviados aos tribunais do Vice-Almirantado britânico aumentaria exponencialmente. Durante o lustro que se seguiu à publicação do Bill Aberdeen cerca de 400 navios brasileiros destinados ao tráfico ilegal foram capturados em águas nacionais, internacionais, ou na costa do continente africano. Não tardou muito para que todas essas operações da armada britânica, principalmente as que tomaram de assalto a costa e os portos brasileiros, gerassem uma crise política no Império, e acelerassem a promulgação da Lei $n^{\circ} 581$, conhecida como a Lei Eusébio de Queiroz, publicada no dia 4 de setembro de 1850, e que acabaria refletindo a disposição do governo brasileiro em suprimir, ele próprio, a importação ilícita de cativos provenientes da África. Ao que tudo indica, o tráfico transatlântico de escravos estaria mesmo com seus dias contados ${ }^{73}$.

às pretensões da Grã-Bretanha. Embora o tráfico já estivesse desautorizado por essas nações, nem uma nem outra concordariam que a armada britânica vistoriasse seus navios mercantes. A França, por outro lado, recrudesceria sua legislação anti-tráfico no correr da década de 1820 e, por conseguinte, diminuiria a quantidade de cativos importados por algumas de suas colônias. Fora somente em novembro de 1831, após novas negociações com a Grã-Bretanha, que a França lhe concederia o tão almejado direito de busca, porém sob a condição de que seriam os tribunais franceses que julgariam os navios capturados. Alguns anos mais tarde, em março de 1833, esse direito de busca seria ampliado para fazer constar a cláusula de equipamento e a possibilidade de destruição das embarcações negreiras apresadas. Dentre as nações americanas, o Chile assinara um tratado com Grã-Bretanha abolindo o comércio transatlântico de escravos no dia 19 de janeiro de 1839. No mesmo ano, a Venezuela ( $1^{\circ}$ de março), o Uruguai (13 de junho), a Argentina ( 24 de maio) e o Haiti (23 de dezembro), todos eles concordaram em abolir o tráfico. Alguns anos depois chegara a vez do México (24 de fevereiro de 1841) e do Texas (16 de novembro de 1841) cederem às pressões que já refletiam boa parte da opinião pública mundial. Ainda em 1841 consolidou-se a convenção das cinco nações (Inglaterra, Áustria, França, Prússia e Rússia) que passariam a tratar o tráfico negreiro como pirataria. Cf. BETHELL, Leslie, op. cit., p. 32; 36; 100-101; cf. PARRON, Tâmis Peixoto, A política da escravidão no Império do Brasil, 1826-1865, p. 146-147.

${ }^{73}$ O Projeto da Lei Eusébio de Queiroz foi aprovado na Assembleia Geral em 17 de julho de 1850 e, no Senado, no dia 13 de agosto de 1850 . O primeiro artigo da Lei fazia menção direta à Lei de 7 de novembro de 1831, como se vê por seu texto, a seguir: "Art. $1^{\circ}$ As embarcações brasileiras encontradas em qualquer parte, e as estrangeiras encontradas nos portos, enseadas, ancoradouros, ou mares territoriais do Brasil, tendo a seu bordo escravos, cuja importação é proibida pela Lei de sete de Novembro de mil oitocentos trinta e um, ou havendo-os desembarcado, serão apreendidas pelas Autoridades, ou pelos Navios de guerra brasileiros, e consideradas importadoras de escravos. (...)". O Decreto $\mathrm{n}^{\circ} 708$, de 14 de outubro do mesmo ano, regularia "a execução da Lei que estabelece medidas para a repressão do tráfico de Africanos neste Império" e, um mês depois, no dia 14 de novembro de 1850 , outro Decreto, o de $n^{\circ} 731$, regulamentaria o procedimento para as apelações a serem encaminhadas à Seção de Justiça do Conselho de Estado. No dia $1^{\circ}$ de março de 1851 , a Seção de Justiça, então, confirmaria a sentença da Auditoria da Marinha ao entender por bem que os quatro africanos boçais apreendidos na barca francesa Tourville deveriam ser declarados livres e reexportados, muito embora não houvesse indícios de que o capitão da embarcação estivesse, de fato, praticando o tráfico de escravos. No mesmo dia, a Seção resolvia pela confirmação da sentença da Auditoria da Marinha segundo a qual concedera liberdade a 208 africanos boçais apreendidos junto com o iate Rolha, no dia 4 de outubro de 1850 no porto de Macaé. A Resolução de 9 de maio de 1851 fora taxativa em afirmar que a Lei Eusébio de Queiroz deveria ser interpretada extensivamente. A apreensão dos 22 africanos boçais desembarcados havia poucos dias no porto de Manguinhos deveria ser considerada legal, ou seja, deveria ser compreendida como tendo ocorrida "imediatamente depois" (art. $8^{\circ}$, da Lei $\mathrm{n}^{\circ}$ 581) do desembarque, pois, "as palavras 'imediatamente depois' não podem admitir outra significação, senão a de que, entre o desembarque e a apreensão de africanos, não tenha decorrido tanto tempo, nem se tinha interposto ato algum, que os confunda com os escravos existentes no Brasil (...)". "Se não fosse esta a verdadeira e genuína inteligência da Lei, continua o parecer da Seção, salta aos olhos que a competência dos Auditores da Marinha ficaria 
A primeira metade do século XIX fora marcada por alguns momentos em que a combinação de fatores internos e externos ao Brasil veio a contribuir para que a introdução de escravos no país, ou as viagens de costa a costa do Atlântico, fosse intensificada. Alguns desses momentos emergiram em épocas em que a Grã-Bretanha recrudescia sua intolerância ao tráfico de escravos, seja pressionando o governo brasileiro para a assinatura de tratados ou cláusulas adicionais a acordos preexistentes, seja ordenando aos navios de sua armada que fizessem ir ao fundo os negreiros que porventura se arriscassem nas águas costeiras do Brasil ou do continente africano. Os anos de 1826 a 1830, ou o lustro anterior a 1850, parecem ter se revelado num desses momentos. A maior procura dos proprietários por mão de obra escrava pode muito bem indicar que não estiveram alienados ao que se passava no cenário político mundial. Temiam, ao que parece, o fim próximo da principal fonte de reposição da força de trabalho empregada nas lavouras: o tráfico transatlântico, negócio muito lucrativo principalmente para os traficantes estabelecidos na província do Rio de Janeiro nesses primeiros cinquenta anos do oitocentos ${ }^{74}$, e que continuaria a se arriscar nas águas do Atlântico apesar das tentativas de interesses externos se sobreporem aos interesses econômicos estritamente bem relacionados com o poder político brasileiro.

O tráfico de cativos para o país se constituía de fato num negócio muito lucrativo para quem o praticasse. Mas, de igual modo, muito custoso, pelo menos nos primeiros momentos do empreendimento, pois, seria necessária certa disponibilidade de crédito na praça que pudesse ser destinado ao financiamento da montagem das embarcações que viajariam ao continente africano. Esses gastos iniciais seriam empregados quase que completamente na aquisição do navio, seja por meio da compra, aluguel, etc.; no

efetivamente limitada, contra o espírito e fins da Lei, aos casos de apreensões feitas no alto mar, e antes do desembarque, porque todos sabem e reconhecem, que nada seria tão difícil como acudir no mesmo momento ou sucessivamente a tais desembarques em lugares de propósito escolhidos para ocultá-los", cf. CAROATA, José Próspero Jeová da Silva. Imperiaes resoluções tomadas sobre consultas da secção de justiça do conselho de estado, vol. 1, p. 265-266. Ainda no ano de 1851 foram confirmadas em 2a instância, pela Seção de Justiça do Conselho de Estado, a sentença emitida pela Auditoria da Marinha ( $1^{\mathrm{a}}$ instância) que concedera a liberdade a 485 africanos apreendidos com a barca Tentativa, que encalhou em Ubatuba no dia 16 de fevereiro (Resolução de 2 de julho); outra sentença que considerara o bergantim Catão como embarcação usada no comércio transatlântico de escravos, e portanto apreendido como se boa presa fosse (Resolução de 5 de julho); outra, que julgara boa presa o brigue Encantador, "não obstante ter sido feito o apresamento um só dia antes da publicação do Regulamento n. 708 de 14 de Outubro de 1850, visto como a falta de Regulamento não pode embaraçar a execução de uma Lei já publicada.” (Resolução de 5 de novembro). Em 1852, a Resolução de 17 de julho confirma a sentença da Auditoria da Marinha que apreendera um palhabote e concedera liberdade aos africanos boçais com base na Lei de 7 de novembro de 1831. Alguns anos depois da publicação da Lei Eusébio de Queiroz, o Decreto no 731 de 5 de junho de 1854 ampliaria os poderes dos Auditores da Marinha para o julgamento das presas em $1^{\mathrm{a}}$ instância.

${ }^{74}$ Cf. FLORENTINO, Manolo, op. cit., p. 44. 
sortimento dos gêneros indispensáveis seja ao escambo na costa da África ou ao sustento da tripulação e dos cativos trazidos na viagem de volta; ou no aparelhamento da nau com os equipamentos essenciais e específicos a qualquer empreendimento negreiro. Um empreendimento caro, enfim, e que muito poderia contribuir para a prosperidade da capital do Império, pois no período que se prolonga à instalação da Corte na cidade até 1833, "um mínimo de três quartos dos negreiros que atuavam entre o porto carioca e a África eram propriedade dos traficantes estabelecidos na praça do Rio de Janeiro" ${ }^{\text {"75. }}$

O tráfico transatlântico de escravos atraía boa parte dos investimentos dos capitalistas fluminenses, mas nem por isso fora destituído de riscos imanentes a qualquer empresa marítima, e especialmente aos empreendimentos negreiros de tamanho porte. A lucratividade do negócio, portanto, também estaria diretamente relacionada ao modo como os negociantes lidariam com todos esses riscos. As viagens de costa a costa do Atlântico por si só punham as embarcações em contato com os constantes perigos do trânsito marítimo. Abalroações, avarias ou mesmo o naufrágio tanto poderiam acontecer em alto mar como nas águas rasas das costas ou dos portos, causando inúmeros prejuízos aos proprietários dos navios, ou a quem os arrendasse, e aos donos das mercadorias transportadas.

Geralmente, quando algum interessado por escravos aportava na costa africana principalmente na região de Angola, na costa ocidental do continente, ou nas águas de Moçambique, do lado oriental da África - daria início ao trato com negociantes locais e estes, já munidos dos gêneros apropriados, é que negociariam o escambo com chefes tribais das áreas situadas mais ao interior do continente africano, e que trariam até a costa os cativos capturados nas guerras decorrentes de toda essa trama econômica. Os riscos que porventura viriam acometer a vida desses prisioneiros, ou outros perigos que pudessem perturbar a previsão dos negócios, estariam presentes já nesses momentos iniciais da captura. $\mathrm{O}$ deslocamento do interior até os postos de embarque no litoral africano já seria arriscado à vida dos cativos, ou pelo menos propício aos roubos e fugas acontecidos durante o trajeto. Nos barracões construídos para o armazenamento, ou mesmo nos navios ancorados em que os escravos esperavam o dia da partida, havia novas chances de mortes, fugas ou roubos. Todas essas possibilidades, de igual modo, estariam presentes quando,

75 Ibidem, p. 120-121. Para as exigências do empreendimento em suas etapas iniciais, ibidem, p. 119-120, 115-116. 
uma vez chegados aos portos de desembarque no Brasil, os cativos fossem trasladados para as fazendas localizadas no interior das províncias ${ }^{76}$.

Em maior ou menor grau, a taxa de lucros que poderia ser obtida mediante o trato negreiro estaria estritamente relacionada à maior ou menor ocorrência de todos esses perigos. Mas, ao que parece, a maior ou menor rentabilidade proporcionada pelo negócio dependeria também dos riscos a que estavam expostas as vidas dos cativos, a serem enfrentados em outra etapa do empreendimento, a que se demoraria por alguns meses durante o trânsito marítimo. Talvez fosse durante a travessia do Atlântico que as vidas dos cativos se perdessem em maior quantidade - seja em decorrência de doenças, fome, assassinatos, suicídios, etc. -, a depender das circunstâncias e também da duração da viagem: se partindo da costa ocidental da África, a probabilidade de menos mortes dentre os escravos seria maior, pois este trajeto poderia ser percorrido em mais ou menos cinco semanas, menor tempo, portanto, que o retorno da costa oriental do continente africano, que invariavelmente levaria em torno de 75 dias; umas e outras, independente do ponto de partida, começariam a chegar ao Rio de Janeiro por volta do mês de agosto, intensificandose o número de desembarques nos meses do verão (dezembro e janeiro), e diminuía entre os meses de fevereiro a maio, e seriam mais escassos no inverno ${ }^{77}$.

Os empreendedores das viagens à África eram conscientes dos riscos a serem contornados, e das perturbações que causariam se não o fossem, e era do costume do comércio computar no orçamento do negócio algo além dos custos de aquisição das embarcações, e também dos valores da estocagem dos gêneros destinados ao escambo na costa africana e ao sustento da equipagem e dos cativos a serem trazidos pelas naus. Tão importante quanto, os traficantes invariavelmente seguraram suas embarcações contra os eventuais danos que poderiam sobrevir aos cascos, ou mesmo contra a perda total do navio caso ele viesse a pique; mas, tão comum quanto o eram os seguros das naus, os negociantes contratavam os seguros também para se garantirem contra os prejuízos que as eventuais perdas de gêneros, equipamentos e mercadorias pudessem lhes provocar.

Na passagem do século XVIII para o século XIX, a contratação de seguros sobre os riscos que acometiam a carregação de escravos foi tão frequente como o foram as próprias

\footnotetext{
${ }^{76}$ Ibidem, p. 140-141. Diante dessa teia de relações comerciais entre o continente africano e o Brasil, Manolo Florentino sugere a expressão tráfico "afro-americano" como forma de caracterizar o tráfico transatlântico de escravos, pois, "além de reproduzir estruturalmente a força de trabalho na América, também desempenhava um papel estrutural na África", implicando em movimentos conformadores das sociedades situadas nos dois lados do Atlântico, cf. ibidem, p. 100.

${ }^{77}$ Ibidem, p. 60-61, 145-146, 172-173.
} 
expedições negreiras ao continente africano. Em termos mais específicos, esses seguros visavam garantir os empreendedores das viagens contra os riscos de rebeldia escrava e de morte dos cativos, que corriqueiramente acompanharam as embarcações durante as travessias de retorno ao continente americano. Contudo, reconhecia-se que nem todas as perdas deveriam ser indenizadas pelos seguradores. Como era costume na prática desse negócio, suas responsabilidades estiveram estritamente relacionadas aos casos em que as mortes dos cativos sobrevieram dos infortúnios que acometeram a navegação em circunstâncias "normais", ou quando foram tomadas pela rebeldia escrava. Mas, neste último caso, haveriam de ser consideradas, particularmente, as condições sob as quais as vidas foram se perdendo. Nesse sentido, José da Silva Lisboa, o Visconde de Cairu explica que

\footnotetext{
Por virtude deste Seguro, se os Negros se rebelam no mar, e por este levantamento ocasionam o naufrágio, varação, e perda de viagem (como tem acontecido), ou sobrevém outro qualquer acidente desta natureza, e efeitos, os Seguradores respondem pelo dano total, ou parcial do Navio, e carregação, até a concorrência da quantia segurada; por se considerar este infortúnio como caso extraordinário, fatal, e de força maior. ${ }^{78}$
}

Pelos mesmos motivos, ou seja, pela impossibilidade de se defender ou de afastar qualquer adversidade da natureza, os seguradores de igual modo seriam chamados a indenizar os segurados quando, em decorrência de uma eventual tempestade, os escravos caíssem ao mar; ou quando falecessem por moléstias que lhes infectaram em algum porto ancorado. Houve situações, algumas vezes noticiadas, em que foram lançados ao mar os escravos enfermos, ou os selecionados, para que assim fossem poupadas as vidas de outros cativos julgados mais sadios. Tal fora o caso, por exemplo, do famoso incidente envolvendo o navio negreiro inglês Zong, ocorrido em 1781, quando transportava escravos capturados no continente africano para a Jamaica. Durante a viagem a tripulação capitaneada por Luke Collingwood recebeu ordens de jogar 132 africanos desfalecidos ao mar, como meio de salvar as vidas dos escravos que ainda não tinham sido atingidos por doença alguma ${ }^{79}$. Os seguradores, quando procurados pelos segurados, recusaram-se a ${ }^{78}$ Cf. Cf. LISBOA, José da Silva, Visconde de Cairu, Princípios de direito mercantil e leis de marinha,
capítulo XXIV: Do Seguro de carregação de escravos, e de bestas, p. 43 .
79 Cf. CHEN, Cheryl Rhan-Hsin; SIMON, Gary, Acturial issues in insurance on slaves in the United States
South, p. 349 . O caso Zong, como ficou conhecido, ocorrera cerca de dezessete anos antes que o primeiro
Tratado dos Princípios de direito mercantil e leis de marinha, de José da Silva Lisboa, viesse a lume. Em sua
obra, o Visconde de Cairu faz menção a um caso parecido que, ao que tudo indica, pode muito bem ser o
mesmo. Diz ele que "Allan Park, Capítulo III, indica um exemplo atroz de desgraça semelhante, que
horroriza a toda a alma sensível aos males da humanidade. Um navio voltando da Costa de Guiné para 
indenizá-los por suas perdas. Ao que parece, acabaram sendo obrigados ao pagamento pela sentença de primeira instância, mas a decisão foi modificada em grau de apelação.

Por outro lado, nos casos em que a rebeldia escrava tomasse conta do navio, os seguradores seriam responsáveis pelas vidas perdidas se, durante o levantamento, os cativos foram mortos pela equipagem quando da tentativa de controlar o movimento. A responsabilidade seria a mesma caso os óbitos viessem a ocorrer em momentos posteriores à rebelião, porém em decorrência dos ferimentos advindos do confronto, pois, como se dizia, a perda dever-se-ia "reputar uma consequência direta e próxima da rebeldia dos mesmos escravos" ${ }^{\prime 80}$. Mas, pelo contrário, não haveria que se falar na obrigatoriedade dos seguradores de indenizarem os escravos que, uma vez sobreviventes ao combate sucedido ao levantamento dos africanos, por qualquer motivo que seja se lançassem ao mar, ou se deixassem vencer pela fome. Tampouco tal responsabilidade caberia se a discussão versasse apenas sobre a deterioração sofrida pelo preço do cativo que, em decorrência de sua participação nos conflitos com a equipagem do navio, fora apresentado em mau estado à oferta, na praça. Nesses casos

\footnotetext{
(...) além de serem tais prejuízos consequências remotas, e não conexas necessariamente com a rebeldia, julgam-se com razão procedidas de vício intrínseco, e natural decaimento da coisa segurada: e os Seguradores, pela natureza do contrato, só devem a indenidade, quando a mesma coisa não chega a salvamento ao lugar do destino, e nada lhes importa o êxito da especulação, de quem requereu o Seguro, sendo-lhes igualmente estranhos o benefício, ou a desvantagem do mercado. ${ }^{81}$
}

Quando em circunstâncias "normais", ou seja, quando não houvesse rebeldia ou levantamento algum por parte dos cativos, a ocorrência de alguns casos livraria os seguradores de qualquer responsabilidade pelas perdas sucedidas durante o transporte

Jamaica carregado de escravos, teve uma viagem tão infeliz, e prolongada, que faltando água, o Capitão, e Equipagem foram de parecer que se lançasse ao mar parte dos negros, que se transportavam; o que barbaramente se executou, e deu motivo a que o Segurado, por cuja conta haviam sido carregados os negros, demandassem aos Seguradores o pagamento do seu valor, como de perda acontecida por perigos do mar", cf. LISBOA, José da Silva, Visconde de Cairu, op. cit., p. 43. A obra citada por Silva Lisboa muito provavelmente seria A System of the Law of marine insurances, de autoria de James Allan Park. No terceiro capítulo de sua obra, Park relatara os fatos: "The facts, appearing in evidence, were, that the ship, being bound from Guinea to Jamaica, had missed the island, and the crew were reduced to great distress for want of water; that the captain consulted with the crew, and it was unanimously agreed upon, that some of the slaves should be thrown overboard, in order to preserve the rest (...)" (Os fatos, ora em evidência, foram, que o navio, viajando da Guiné para a Jamaica, perdeu a ilha, e a tripulação foi acometida por uma grande preocupação provocada pela falta de água; o capitão se consultou com a tripulação, e foi por unanimidade acordado, que alguns dos escravos deveriam ser lançados ao mar, como forma de preservar o restante [dos cativos] - tradução nossa), cf. PARK, James Allan, A System of the Law of marine insurances, p. 70.

${ }^{80}$ Cf. LISBOA, José da Silva, Visconde de Cairu, op. cit., p. 44.

${ }^{81}$ Ibidem, p. 44. 
marítimo, justamente por se entender que também configurar-se-iam em perdas decorrentes do "vício intrínseco", ou do "natural decaimento da coisa segurada". Os suicídios; os assassinatos que porventura os africanos cometessem contra a vida de seus pares, seja por enforcamento, pelo emprego de armas ou não; as mortes provocadas por doenças naturais; as perdas provocadas porque os cativos se atiravam ao mar; ou quando, "deixando-se inanir por inédia, não querendo tomar o alimento necessário (que muitas vezes acontece) ${ }^{» 82}$, sucumbiam à persistência da morte; em todas essas situações os prejuízos que acometiam os patrimônios dos segurados deveriam ser suportados por eles próprios $^{83}$.

Nos demais casos em que o sinistro fosse provado, seus patrimônios poderiam ser parcial ou integralmente recompostos pelas indenizações a que teriam direito receber dos seguradores, conforme ia nos termos previamente assinados no contrato, ou particularmente para os seguros, na apólice. Especificamente sobre os seguros que se contratavam para que os riscos inerentes à carregação de escravos fossem garantidos, não bastaria que esta intenção fosse inclusa dentre as condições da apólice debaixo somente da denominação genérica de mercadorias e efeitos. Exigiria, portanto, uma declaração expressa do que fosse pretendido segurar em determinada viagem, com exceção apenas das que retornassem da "Costa d'África; porque costumando ser principal parte em escravos, não ignoram os Seguradores esta circunstância, a designação específica lhes é indiferente." ${ }^{84}$.

Os seguros marítimos, sem dúvida, seriam indispensáveis à travessia do Atlântico, mas em alguns casos seus custos bem poderiam abocanhar boa parte dos lucros esperados

${ }^{82}$ Ibidem, p. 43.

${ }^{83}$ Já no final do século XIX, José da Silva Costa busca uma definição para o "vício intrínseco", ou próprio. Dizia ele que "No sentido particularmente pertencente ás relações jurídicas do contrato de seguro, o vício próprio exprime as deteriorações, destruições ou perdas, determinadas por acidentes, aos quais a coisa da mais perfeita qualidade em seu gênero está sujeita por sua natureza: assim as fazendas de lã, a peleteria estão sujeitas ao bicho que as pode deteriorar e destruir", cf. COSTA, José da Silva, Seguros marítimos e terrestres, p. 66. Nos casos de seguros sobre a carregação de escravos, as mortes decorrentes de suicídios, de doenças naturais (que não foram contraídas em um dos pontos ancorados pelo navio, durante a viagem), de inanição voluntária, etc., constituem-se perdas advindas da própria natureza do ser humano e, por isso, não poderiam ser tomados como riscos, tampouco como sinistros, propriamente ditos. As mortes, ou as perdas, que vinculavam a responsabilidade do segurador à obrigação de indenizar, seriam aquelas sucedidas quando da ocorrência dos riscos (seguráveis) do transporte marítimo. Os infortúnios do mar, as tempestades, os ventos fortes, todos eles poderiam comprometer a navegação e causar prejuízos aos navios e às cargas. Se o carregamento fosse de escravos, entendia-se que o sucesso do empreendimento estaria a depender também da ocorrência, ou não, de outro risco segurável: o da rebeldia por parte dos cativos. Neste caso, se as vidas se perdessem em decorrência de levantamentos, por essas mortes estariam responsáveis os seguradores.

${ }^{84}$ Cf. LISBOA, José da Silva, Visconde de Cairu, op. cit., p. 43. 
ao final do empreendimento. Ao que tudo indica, o valor do prêmio a ser pago pelo seguro de uma embarcação, ao menos durante as décadas de 1820 e 1830, "poderia corresponder a 10 por cento do valor do navio e das mercadorias somadas" ${ }^{\$ 2}$, valor a depender da avaliação do risco a ser contratado, que deveria levar em consideração as circunstâncias sob as quais a nau iria navegar; e valor que as relações e as articulações dos traficantes do Rio de Janeiro poderiam minorar.

Talvez o que tivesse sido uma oportunidade comercial aproveitada pelos traficantes cariocas de igual modo o fora por negociantes das outras praças mercantis do Império brasileiro ou mesmo do mundo. Ou talvez nem tivesse sido propriamente uma oportunidade, mas uma situação que a própria estrutura da economia e a disposição dos capitais e dos agentes que nela atuavam paulatinamente iriam conformando. Isso quer dizer que os lucros convertidos pelo tráfico não regressariam, necessariamente, e em sua integralidade, à realimentação do negócio, principalmente na aplicação do dinheiro para a aquisição e o abastecimento das embarcações. Ao que parece, pelo menos parte deste capital também poderia ter sido reinvestido em outros ramos do comércio, direta ou indiretamente relacionados ao tráfico, e que da mesma forma contribuíram para modelar a economia coeva. Verificou-se, por exemplo, que foram frequentes, pelo menos durante os primeiros trinta anos do século XIX, as intromissões dos traficantes do Rio de Janeiro - e além deles de muitos indivíduos ou famílias que de uma forma ou de outra investiam no comércio transatlântico de escravos -, nos negócios das companhias de seguros estabelecidas na praça comercial da mesma província, seja como acionistas, ou mesmo mediante a participação nos quadros administrativos ou diretivos dessas mesmas seguradoras.

Seria demasiadamente arriscado deixar à deriva o destino de grandes fortunas, individuais ou familiares, intensamente empregadas neste negócio. Qualquer perda decorrente do acaso dos oceanos, dos piratas, ou mesmo da senhora dos mares, poderia levar à falência indivíduos, famílias, ou sociedades mercantis empenhadas em adquirir navios ou prepará-los para as viagens.

${ }^{85}$ Cf. BOHRER, Saulo Santiago, “Interesses Seguros”, p. 65. Este valor pode ser verificado, segundo Bohrer, em documentos constantes de um processo contra a Companhia de Seguros Indemnidade, guardado na Caixa 431 do Fundo da Real Junta do Comércio, Agricultura, Fábricas e Navegação, no Arquivo Nacional do Rio de Janeiro. Portanto, provavelmente estaria indicando o valor de um prêmio cobrado pela referida seguradora para que garantisse algum risco contratado. 
Tão indispensável ao comércio transatlântico de escravos, os seguros que se faziam sobre as embarcações negreiras, e também contra os riscos que poderiam acometer as vidas dos cativos transportados do continente africano, estariam com seus dias contados. Se a proibição legal não fez cessar o tráfico nos anos que se seguiram a 1831, certamente ele fora extinto pela intensa perseguição que vinha sofrendo da armada britânica desde o início da década de 1840, bem como dos navios de guerra brasileiros que, principalmente após 1850, decidiram fazer valer a letra da Lei Eusébio de Queiroz. Contudo, uma vez na ilegalidade, os anos corridos durante as décadas de 1830 e 1840 muito provavelmente conheceram as artimanhas dos negociantes para que a segurança do tráfico negreiro, então ilegal, continuasse a ser garantida, como dantes o fora, pela contratação dos seguros ${ }^{86}$.

${ }^{86}$ Bohrer chama a atenção para uma época em que os empreendedores das expedições à costa da África devem ter encontrado alguma dificuldade para contratarem os seguros marítimos de embarcações negreiras, e também de vida dos cativos trazidos para o continente americano. Trata-se do período iniciado com a promulgação da Lei de 7 de novembro de 1831 - que declarou livre todos os africanos entrados no Brasil a partir de sua publicação, ao mesmo tempo em que previu penalidades aos colaboradores do tráfico ilegal - e que se prolongaria pelos próximos vinte anos. Durante todo esse tempo, como se sabe, o comércio transatlântico de escravos esteve proibido por lei, porém intensamente praticado pelos traficantes, em sua maioria estabelecidos na província do Rio de Janeiro. Contudo, se anteriormente à aprovação da lei de 1831 a contratação dos seguros marítimos fora tão indispensável ao sucesso do comércio negreiro, tudo indica que sua relevância deve ter continuado apesar deste negócio ter entrado para a ilegalidade. No entanto, esta proibição deve ter afetado, de algum modo, a harmonia do mercado segurador carioca que, pelo menos durante os primeiro trinta anos do século XIX, negociara amplamente sobre os riscos provenientes da navegação marítima. Bohrer entende, especialmente em dois momentos de sua obra, que os seguros marítimos dantes contratados pelos negociantes negreiros, estariam proibidos de o ser para a garantia do sucesso do tráfico ilegal. Nesse sentido, ele afirma que "A lei de 1831 contra o tráfico tornava impossível que, juridicamente, os negreiros pudessem fazer apólices legítimas de seguro. Esta afirmação precisa ser testada com mais profundidade, mas tudo nos leva a crer que as seguradoras a partir de 1831 começaram a amargar uma redução cada vez maior de seus lucros, principalmente, com os negócios escravistas. Como era ilegal a atividade negreira era igualmente a realização de seguros de navios e das mercadorias envolvidas no infame comércio.", cf. BOHRER, Saulo Santiago, op. cit., p. 67. Em outra passagem, o autor continua afirmando que "A lei contra o tráfico, mesmo que não cumprida efetivamente, ficando conhecida como "lei para inglês ver', tornava todos os comerciantes de escravos em traficantes, o que legalmente possuía impactos negativos ao mercado de seguros. Uma vez considerada como atividade ilegal, o comércio de escravos não poderia ser coberto pelas companhias integralmente. Assim, deste momento em diante as empresas teriam problemas legais de cobrir sinistros em que a embarcação estivesse carregada de escravos. Obviamente, o seguro ficaria restrito somente ao casco e aos aparelhos", ibidem, p. 122. Por este segundo trecho, podemos perceber que o autor admite a possibilidade da contratação de seguros sobre determinados riscos da atividade negreira, em detrimento de outros (especificamente sobre os navios, e não sobre o carregamento de escravos). Contudo, o primeiro excerto, além de trazer uma posição mais radical sobre o status jurídico atribuído a esse ramo do negócio segurador após a publicação da lei de 1831 (os seguros sobre as embarcações negreiras foram considerados ilegais juntamente com o tráfico de escravos), de igual modo chega a formular uma hipótese a ser averiguada em pesquisas posteriores: a de que o mercado segurador sofreu um impacto negativo (no que diz respeito à lucratividade das companhias seguradoras) em decorrência da proibição do comércio negreiro. Embora concordemos se tratar de um problema a ser investigado com mais vagar, e embora este não seja o espaço adequado para nele nos aprofundarmos em busca de uma solução que satisfizesse todas as especulações; não podemos deixar de mencionar outra hipótese que porventura permita vislumbrar um comportamento dos negociantes - sejam eles traficantes ou seguradores quando pretenderam driblar as proibições impostas numa dada época que, totais ou parciais, muito provavelmente afetariam drasticamente o sucesso de seus negócios se fossem tão logo contornados. Trata-se de uma informação trazida por José Ferreira Borges, e que nos permite conhecer os artifícios adotados pelos negociantes, pelo menos os de meados do século XIX, para escaparem de situações semelhantes às sucedidas 
Se o tráfico negreiro, sobrevivente á aprovação da Lei de 7 de novembro de 1831, deve ter continuado a demandar, de alguma forma, a contratação dos seguros contra os frequentes riscos que acometiam as vidas dos cativos durante a travessia do Atlântico, certamente, com a extinção de fato do comércio proibido de escravos, o mercado segurador viu cessar a oferta desse serviço durante os anos da década de 1850 . No entanto, se a vida do escravo deixava de ser objeto dos seguros marítimos à medida que se interrompia a importação de mão de obra africana para o Brasil, por outro lado, em terra, e numa sociedade que persistiria escravista como seria a carioca até os últimos momentos do Império, a vida escrava continuaria a ser segurada por companhias, ou associações, todas dispostas a indenizar os proprietários caso fossem despojados de parte de seus patrimônios. Fica por conta dos capítulos seguintes a apresentação dessas seguradoras que, em determinadas épocas, enxergaram uma a oportunidade acenada pelo mercado estabelecido na província do Rio de Janeiro, principalmente a partir de meados do século XIX.

pela promulgação da lei de 1831. Diz o jurista português que "Como as leis começaram por proibir os seguros de muitas coisas, e os negociantes conheceram o erro dessas leis, não tiveram remédio senão lançar mão d'um meio, que pendia todo da sua honra e palavra, sem lhe dar ação judicial a seus contratos; e assim começaram estes seguros de confiança e d'hora, que ainda hoje se praticam todos os dias em muitas praças, principalmente em Londres, e talvez além do rigoroso dever e moralidade, como acontece nos contrabandos do país próprio", cf. BORGES, José Ferreira, Diccionario Juridico-Commercial, p. 384. Como se vê, a contratação dos seguros como forma de garantir os empreendimentos negreiros parece ter continuado mesmo em tempos de proibição do tráfico. A diferença residiria em que, em tempos difíceis, os contratos passariam a ser realizados à base da confiança mantida entre os negociantes, e as apólices, outrora a única prova da existência do negócio, não seriam reduzidas "a escrito, quer no todo, quer em parte de suas condições", ibidem, p. 383. 


\section{CAPÍTULO 2: O MERCADO SEGURADOR DA PRAÇA COMERCIAL DO RIO DE JANEIRO, SÉCULO XIX.}

\section{O Negócio dos seguros.}

Em agosto de 1808, portanto cerca de cinco meses após a chegada da Corte ao Rio de Janeiro, foi criado nessa mesma cidade o Tribunal da "Real Junta do Comércio, Agricultura, Fábricas e Navegação deste Estado e Domínios Ultramarinos”, que entenderia e decidiria sobre "todas as matérias relativas aos objetos de sua instituição", ao mesmo tempo em que seria competente para a inspeção dos objetos que antes o eram da recém extinta Mesa de Inspeção. O que justificaria a criação desse órgão em terras brasileiras estaria estritamente relacionado à situação peculiar vivenciada pela Corte portuguesa na passagem do século XVIII para o XIX. Se as investidas napoleônicas impossibilitaram a permanência da monarquia na península ibérica, provocando o traslado do governo português para sua única colônia no continente americano, consequentemente tornaram incomunicáveis muitas das instituições instaladas na antiga sede do Reino lusitano ${ }^{87}$.

Seria preciso restabelecer a ordem interna conturbada por Napoleão e seus aliados. Seria preciso, então, trazer para a nova capital do Império Ultramarino a política e as instituições indispensáveis à sua sobrevivência. Dentre tantas outras instituições administrativas, fazendárias ou judiciárias, transplantadas ou recriadas pela Coroa, o Tribunal da Real Junta foi constituído, particularmente, tendo-se em vista o incremento do comércio, ou dos negócios, em que eram parte interessada tanto os muitos vassalos de D. João, como o próprio Estado português. E havia expressa menção quanto a isso no Alvará que o instituiu. Aliás, o texto do documento dizia algo mais, dizia que "depois que determinei [o príncipe regente] que fosse livre o erigirem-se fábricas de qualquer gênero e

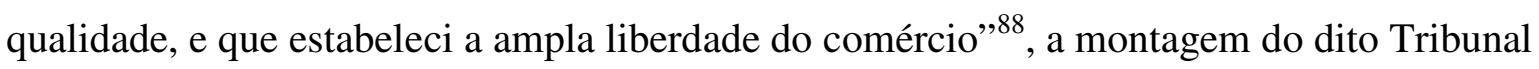
viria para dar conta tanto das causas impossíveis de serem apreciadas pelo órgão

\footnotetext{
${ }^{87}$ Cf. Alvará de 23 de agosto de 1808. As citações que compõem a narrativa deste e do próximo parágrafo são excertos extraídos do texto apresentado pelo referido Alvará.

${ }^{88}$ Esta citação traz referência a duas medidas econômicas tomadas anteriormente à instituição do Tribunal da Real Junta do Comércio, Agricultura, Fábricas e Navegação. Trata-se, em primeiro lugar, da liberdade para a constituição de fábricas e manufaturas no território da colônia brasileira, concedida pelo Alvará de $1^{\circ}$ de abril de 1808; e, posteriormente, da abertura dos portos brasileiros ao comércio internacional, que pôs fim à secular relação mantida entre metrópole e colônia nos limites impostos pelo sistema colonial - Alvará de 28 de janeiro de 1808 .
} 
competente situado em solo europeu, como para cuidar das contendas que surgiriam em decorrência do recrudescimento das transações mercantis que, como se apostava, estariam mesmo por ser intensificadas; e também apresentar propostas "que puder concorrer para o melhoramento de objetos tão interessantes ao bem do Estado". O Tribunal da Real Junta, então, configurou-se na terceira de uma série de medidas adotadas pelo governo para o progresso e a celeridade do comércio nacional, apaziguando assim os interesses dos particulares simultaneamente à alimentação de uma fonte propícia à manutenção financeira da monarquia lusitana.

No entanto, o incremento das transações comerciais portuguesas ainda seria tema que tão logo não escaparia às preocupações do governo. Não tardaria muito até que outras medidas econômicas destinadas a incentivá-las fossem de igual modo adotadas pelo Estado. De fato, passados quase dois anos de sua criação, a Real Junta do Comércio, entendendo pela necessidade e conveniência da proposta, fez subir ao príncipe regente uma consulta em que defendia a revogação, pelo menos parcialmente, da legislação lusitana proveniente dos séculos XVII e XVIII. Dessas leis constavam algumas prescrições que vinham emperrando muitas iniciativas dos vassalos portugueses de armarem embarcações necessárias ao transporte de suas mercadorias até mercados estrangeiros. Foi assim que D. João, então, conformando-se com o parecer da consulta, e "desejando promover e adiantar cada vez mais o comércio nacional (o que muito quer dizer o comércio marítimo), dandolhe maior extensão e facilidade possíveis, e removendo-lhe todos os obstáculos e estorvos", subtraiu a Ordenação do liv. $4^{\circ}$ tit. 67, e parte do Alvará de 17 de janeiro de 1757, do corpo legislativo que constituía o direito luso.

Uma e outra norma, em termos gerais, diziam respeito ao tratamento que a usura vinha recebendo do governo e do direito português. Mas, além disso - e especialmente o Alvará de 1757 -, dispunham sobre a regulamentação a que estava adstrito o contrato de câmbio marítimo ou, caso queira, o dar dinheiro a risco ${ }^{89}$. O Alvará de 5 de maio de 1810

\footnotetext{
${ }^{89}$ Os diplomas falam por si mesmos. O Título 67, do Livro $4^{\circ}$ das Ordenações, denominado "Dos contratos usurários", fora taxativo quanto à proibição da prática da usura dentre os vassalos do Reino lusitano: "Nenhuma pessoa, de qualquer estado e condição que seja, dê ou receba dinheiro, prata, ouro, ou qualquer outra quantidade pesada, medida, ou contada á usura, por que possa haver, ou dar alguma vantagem, assim por via de empréstimo, como de qualquer outro contrato, de qualquer qualidade, natureza e condição que seja, e de qualquer nome que possa ser chamado". Pelo Alvará de 17 de janeiro de 1757 foi ordenado que "se não possa dar dinheiro algum a juro, ou a risco, para a terra, ou para fora dela, que exceda a cinco por cento cada ano; proibindo igualmente o abuso praticado por alguns homens de negócio, de darem e tomarem dinheiro de empréstimo com o interesse de um por cento cada mês". O que o motivara foram "as excessivas usuras, que algumas pessoas costumam levar do dinheiro, que emprestam à juro, e à risco para fora do Reino, com os afetados pretextos de lucro cessante, dano emergente, câmbio marítimo, e outros semelhantes, de que resulta grave prejuízo ao comércio interior, e externo dos meus fieis Vassalos, e ao bem comum dos meus
} 
ordenava, portanto, que fossem revogadas essas disposições, posto que, conforme alegava a consulta da Real Junta do Comércio, seriam "um dos maiores embaraços que o retardava e diminuía [o comércio nacional]" ${ }^{\prime 90}$.

O câmbio marítimo, segundo as palavras de José Ferreira Borges publicadas em meados do século XIX,

é um contrato d'empréstimo de dinheiro, ou coisa estimável, no qual o emprestador, que toma o nome de dador-a-risco, estipula do mututario [sic], que se denomina tomador, um interesse como preço dos perigos de mar, de que se encarrega, a que se chama prêmio, aceita e adquire a hipoteca especial do objeto, sobre que recai o empréstimo, perde todo o direito à soma emprestada, perdido o objeto hipotecado no tempo e no lugar dos riscos convencionados, tendo só direito à restituição do capital e cobrança do prêmio no caso do complemento feliz da especulação projetada ${ }^{91}$.

Um contrato, como se vê, que bem poderia dar margem a todas as interpretações que viam no acordo uma maneira de se praticar a usura, pois, o prêmio que se pedia como contraprestação do dinheiro dado a risco tanto poderia ser entendido como o juro (livremente estipulado entre as partes) decorrente do empréstimo, ou como a condição necessária para que o dador aceitasse correr o risco, e por conseguinte o instituto tivesse sua validade e identidade dentre os negócios realizados no mercado. De um modo ou de outro, o fato era que o câmbio marítimo seria visto, neste início do século XIX, como um instrumento capaz de acelerar o comércio. $\mathrm{O}$ dador a risco funcionaria como o capitalista que, dentre tantas outras possibilidades para o investimento de seu capital, seria o responsável pelo financiamento das viagens. E uma vez emprestado o dinheiro a um

Reinos (...)". Reconhecendo que uma prescrição com esse teor incentivaria a fraude por parte dos negociantes, o monarca estabeleceu "que pessoa alguma, que emprestar dinheiro a juro, a risco; ou a qualquer outro interesse, para comércio marítimo, não possa emprestá-lo por menos tempo de um ano, contado contínua, e sucessivamente do dia da obrigação. Dela não poderá resultar ação para o mesmo dinheiro emprestado ser pedido antes de se achar completo o referido ano, nem menos se poderá fazer pagamento algum, que seja válido, ainda no caso de ser feito depois de haver findado o ano do empréstimo, se houver celebrado; nem entre as pessoas, que derem, e tomarem dinheiro a juro, para se aplicar ao mesmo comércio marítimo, se poderá fazer contrato de seguro para dentro do Reino, ou para fora dele (...)”. As proibições, contudo, não valeriam para o comércio “que se faz destes Reinos para a Índia Oriental”. As penas para as eventuais inobservâncias da ordem seriam basicamente aquelas estipuladas no título das Ordenações: se descumprida pela primeira vez, perderia "todo o principal, que deu por haver o dito ganho e acrescença, se a já tiver recebida ao tempo, que por nossa parte for demandado, e tudo em dobro para a Coroa de nossos Reinos, e mais será degradado dois anos para a África"; na segunda vez, ao vassalo que descumprisse a ordem as penas lhe seria aplicadas em dobro; e na terceira, seriam tresdobradas. "E o que houver de dar o dito ganho, perca outro tanto, como foi o principal, que recebeu, e mais não. (...)". Foi somente no ano de 1832 que a Lei de 24 de outubro, revogando todas as leis e disposições em contrário, dispôs no seu artigo $1^{\circ}$ que "O juro ou prêmio de dinheiro, de qualquer espécie, será aquele que as partes convencionarem". Assim, reiterou, anos mais tarde, o que ordenara o Alvará de 5 de maio de 1810.

${ }^{90}$ Cf. Alvará de 5 de maio de 1810. As citações deste e dos parágrafos anterior e posteriores são trechos retirados do texto deste documento, a não ser que haja expressa referência a outras fontes.

${ }^{91}$ Cf. BORGES, José Ferreira, Diccionario Juridico-Commercial, p. 65. Ver entrada "Câmbio-marítimo". 
armador, por exemplo, o montante logo seria empregado na preparação das embarcações, no pagamento da tripulação, na compra das mercadorias, no abastecimento de gêneros, etc. Seria, portanto, "por extremo útil ao aumento do comércio marítimo o determinar-se que fosse lícito a qualquer ajustar o prêmio que pudesse conseguir em todas as negociações marítimas".

O Alvará de 1810 exporia ainda inúmeros motivos para a revogação da legislação que proibia as negociações em torno do câmbio marítimo (Ordenações, Livro $4^{\circ}$, Título 67), ou mesmo que limitaria o dar-se dinheiro a risco a uma taxa anual não superior a $5 \%$ (Alvará de 17 de janeiro de 1757). Em primeiro lugar, o valor dos prêmios não deveria mais despertar tanta preocupação dos negociantes, pois certamente seria reduzido, tendo-se em vista a iminente "concorrência dos capitalistas, geral confiança e imunidade legal". Uma vez protegidos pela legislação, os capitalistas poderiam ser reembolsados "facilmente por meio do desconto e endosso das suas letras de risco, hoje em dia justificados e aprovados pelos estilos do comércio e pelo estabelecimento do Banco Nacional”, o que tornaria o negócio mais atraente aos seus investimentos. Além do mais, "da proibição que até agora existia, só resultavam fraudes, convenções simuladas, denúncias imorais e proveitosas aos mal intencionados".

Se o propósito fora incentivar o comércio marítimo entre os negociantes portugueses, a medida tomada foi adequada não só para a recondução do capital disperso em outros ramos do mercado, como também para proporcionar maior segurança aos investimentos decorrentes dos dinheiros dados a risco. Liberar o valor dos prêmios aos ajustes feitos pelos particulares em cada caso acordado pareceu razoável aos objetivos pretendidos,

\footnotetext{
porque desta maneira não só entrariam no giro do comércio muitos cabedais estagnados, sendo impraticável que aos proprietários deles fosse proveitoso dálos a risco pela módica quantia de $5 \%$, quando por essa mesma taxa os podiam dar a juro com segurança de penhores e hipotecas ${ }^{92}$.
}

O Alvará de 5 de maio de 1810 parece ter sido significativo nesse sentido. A concessão que se fez à contratação do câmbio marítimo certamente fora uma medida adotada, dentre tantas outras, com vistas ao incremento do comércio marítimo nacional, pois, ao derrubar as previsões legais que dificultavam a livre estipulação do prêmio que deveria ser pago ao dador a risco pelo dinheiro que emprestara ao tomador, a ordem pode

\footnotetext{
${ }^{92}$ Cf. Alvará de 5 de maio de 1810.
} 
muito bem ter incentivado, como se esperava, a colocação desses cabedais, dantes estagnados em outros investimentos mais seguros, no giro do comércio ou, especificamente, nos empreendimentos marítimos. Maior liberdade aos particulares, portanto, maior liberdade às suas práticas mercantis.

Sobretudo, a ordem publicada pelo Alvará de 1810 parecia estar se afinando à harmonia das ordens que antes se propagaram com os Alvarás de 28 de janeiro de 1808, e de $1^{\circ}$ de abril do mesmo ano e, indiretamente, com a criação do Tribunal da Real Junta do Comércio, Agricultura, Fábricas e Navegação. Todos eles, em algum grau, revelavam algumas das abdicações que Portugal vinha fazendo de seus privilégios de metrópole colonial, em proveito da sua única colônia americana e então nova sede do Reino, bem como de boa porção dos seus territórios ultramarinos. Todos eles, em algum grau, denunciaram que, naquela conjuntura mundial do final do século XVIII, e que se estenderia pelo menos até a primeira quinzena do XIX, o Estado percebia que a sua sobrevivência, e também a sua manutenção, de alguma forma dependeriam do aumento da arrecadação que se fazia sobre as rendas dos negociantes. Incrementar o comércio, portanto, invariavelmente significaria aumentar os ganhos dos particulares, o que, consequentemente, significaria elevar o montante arrecadado pelo Erário Régio.

As ordens vindas com cada um desses alvarás, conforme visto, buscaram incrementar o comércio nacional. Para tanto, as medidas por eles baixadas trataram de minorar a regulação que o Estado exercia sobre esse comércio, ao mesmo tempo em que o tornava mais atrativo aos investimentos e à dedicação dos particulares. A liberdade de comercializar com as nações estrangeiras que mais lhes conviessem, e a liberdade de produzir as mercadorias para um mercado aberto, e não mais estanque, foram umas das primeiras medidas tomadas por D. João assim da chegada da Corte ao Brasil. O Alvará de 1810 talvez tenha sido um reflexo de tudo isso. Ali foi concedida maior liberdade de contratação aos negociantes, especialmente para que pudessem estipular por si mesmos o valor do prêmio a ser pago como contraprestação ao dinheiro dado a risco. Além do mais, defendia que tal liberdade não necessariamente ocasionaria a alta dos prêmios, pois os valores ajustados entre os particulares estariam adstritos às leis de um livre mercado. Ou, em outras palavras, apostava-se na inevitável concorrência que mais cedo ou mais tarde seria conhecida dos capitalistas, como sendo um dos principais fatores capazes de conter o avanço dos preços a níveis que desestimulassem os investimentos nos empreendimentos marítimos. 
Parecia ter sido o reconhecimento, enfim,

\begin{abstract}
de que segundo os verdadeiros princípios de economia política é impraticável e impossível estabelecer uma taxa uniforme nos riscos e perigos do mar, que são de sua natureza desiguais, e que devem variar segundo as estações, distâncias, tempo e circunstâncias das viagens, regulando-se por si mesmo o prêmio segundo o estilo da terra, curso da praça, e maior ou menor quantidade de capitais em circulação ${ }^{93}$.
\end{abstract}

Maiores facilidades ao financiamento das viagens muito provavelmente significaria maior número de embarcações ao mar. Mas, ainda assim, a eliminação dos obstáculos legais à contratação do câmbio, muito embora tenha buscado reconduzir os investimentos e dessa forma aumentar a concentração de capitais nos empreendimentos marítimos, deveria caminhar pari passu às possibilidades do mercado, bem como à sua capacidade de responder ao impacto que invariavelmente tal liberdade de contratação provocaria no comércio de grosso trato. Assim, se a publicação do Alvará de 1810 visou de fato o incremento do comércio, como expressamente comunicava seus motivos, as entrelinhas do documento indiciam que a medida baixada, por si só, não seria bastante para a satisfação desse propósito. O tão esperado recrudescimento das transações marítimas, portanto, ainda estaria a depender da disponibilidade e da participação de inúmeras atividades, que de igual forma, teciam a rede mercantil constituída nessa primeira metade do século XIX.

Estimular o direcionamento dos investimentos capitalistas para o empréstimo a risco, mediante o ânimo à livre estipulação do valor dos prêmios pelas partes contratantes do câmbio marítimo, poderia muito bem repercutir no aumento do número das embarcações postas ao mar, como foi sugerido. Nesse sentido, a maior facilidade com que

\footnotetext{
${ }^{93}$ Cf. Alvará de 5 de maio de 1810. Em termos especificamente jurídicos, o próprio diploma equiparava as razões que permitiam o instituto do câmbio marítimo às que já tinham sido aceitas quando da regulamentação dos seguros marítimos. Nesse sentido, dizia o documento que "sobre ser o contrato do câmbio marítimo assentado em justiça e conforme aos princípios de direito natural, justificando a sua igualdade o tomar o proprietário do dinheiro sobre sua conta o risco pelo prêmio, que ajusta; bem como no contrato de seguros marítimos por esta razão reputado justo e legal, e sustentado outrossim por mui doutos e ortodoxos teólogos e juristas, praticado por muitas Nações civilizadas e comerciantes, e por estas razões já estabelecido e aprovado no referido Alvará de 17 de Janeiro de 1757 para o comércio da Ásia”, aí estaria a justificativa para a aceitação do livre ajuste em torno do valor do prêmio a ser exigido como condição para o dar dinheiro a risco. As idas e vindas sofridas por esse instituto no direito lusitano não foram poucas. José Ferreira Borges enumera alguns diplomas que trataram do assunto. Diz o jurista português que pelo Alvará de 14 de fevereiro de 1609 "era proibido dar dinheiro a câmbio marítimo ou fazendas a risco de nau aos homens do mar e oficiais das viagens da Índia de ida e volta"; passados cerca de 15 anos, o Alvará de 23 de agosto de 1623 "estendeu esta proibição a todas as viagens para quaisquer portos como para a Índia"; o Alvará de 11 de maio de 1655 e o Alvará de 17 de janeiro 1757 impõem limites à prática do câmbio marítimo. Somente em 1810 é que o Alvará de 5 de maio "colocou este contrato no seu verdadeiro pé acerca do prêmio", cf. BORGES, José Ferreira, op. cit., p. 65. Ver entrada "Câmbio-marítimo".
} 
o mercado disponibilizava os financiamentos interessantes às etapas iniciais de qualquer empreendimento marítimo se traduziria na intensificação das viagens oceânicas, tão dispostas a incrementarem as transações comerciais que se praticavam entre as nações. Maior número de navios lançados aos oceanos, que se traduziria no aumento da quantidade das viagens, tudo isso atrairia para bem perto dos negociantes os riscos provenientes do mar. As tempestades; os roubos, as represálias, a pilhagem, ou as presas; o encalho; e mesmo o fogo ou o naufrágio, todos esses infortúnios poderiam acometer as embarcações antes, durante, ou depois da navegação, ancoradas nos portos ou em trânsito nos mares, e sem que marcassem data e hora para o encontro.

O maior ou menor sucesso desses empreendimentos, ou em outras palavras, a maior ou menor rentabilidade do comércio marítimo dependeria e muito da maneira como todos esses riscos seriam tratados por aqueles que se pusessem a enfrentá-los. Não só porque o capitalista que deu seu dinheiro a risco não o faria caso inexistisse alguma garantia contra a perda de seu capital investido, mas também porque a derrocada de um empreendimento de tamanho porte afundaria consigo muitos cabedais da praça.

Os seguros para as embarcações, mas também para os gêneros com que iam abastecidas e para as mercadorias que levavam e traziam das viagens, fora uma alternativa encontrada pelos negociantes, para que conseguissem contornar os perigos inerentes à navegação e assim tornassem seus empreendimentos cada vez mais previsíveis, pelo menos em termos financeiros. Os prêmios pagos aos seguradores, porque aceitaram correr os riscos de uma empresa que não a sua própria, deveriam ser encarados como uma perda certa, não há dúvida; contudo, necessária para se evitar uma perda provável, porém maior, e mais drástica aos negócios ${ }^{94}$.

Os seguradores, assim como os que seguravam os riscos provenientes da realização dos empreendimentos terrestres, a depender da quantidade de apólices subscritas, tanto lucrariam com a arrecadação dos prêmios quanto menor fosse a taxa de ocorrência dos sinistros. E, nesse sentido, beneficiavam-se do que postulava a probabilidade matemática. Com o crescimento das contratações, e à medida que o número das apólices assinadas para a garantia de indenizações de riscos análogos fosse aumentando, dizia ela que a taxa de ocorrência dos eventos segurados tenderia a se estabilizar num determinado patamar, variando conforme as características de cada risco. Isso seria válido para as contratações efetuadas em tempos nada extraordinários. Em períodos de guerra, ou de recrudescimento

\footnotetext{
${ }^{94}$ Cf. LISBOA, José da Silva, visconde de Cairu. Reflexões sobre o comércio de seguros, p. 962.
} 
da repressão ao tráfico negreiro, por exemplo, o que costumava ser acordado deveria ser renegociado. $\mathrm{O}$ evento dos sinistros certamente dependeria também da conjuntura políticoeconômica de uma dada época, mas em regra o cálculo das probabilidades se fazia sentir nas negociações cotidianas.

Os seguros marítimos constituíam, em si, um negócio muito lucrativo nessa primeira metade do século XIX. O cálculo probabilístico, ao que tudo indica, proporcionou aos seguradores alguma previsibilidade dos ganhos e das perdas, tão necessária à administração de qualquer negócio e, assim como o comércio transatlântico de escravos, o setor segurador foi se configurando numa atividade empresarial muito atraente aos investimentos capitalistas. Pelo menos os empreendimentos destinados ao comércio marítimo, fosse ele negreiro ou não, invariavelmente contratariam o seguro para que fossem evitados maiores prejuízos caso as embarcações fossem acometidas pelos infortúnios do mar. O montante dos prêmios acumulados nos caixas das companhias seguradoras, uma vez previstos os gastos que a empresa destinaria à cobertura dos sinistros ocorridos, poderia ser investido na compra de ações de outras companhias capitalistas; na compra de apólices da dívida do Governo; ou mesmo depositado nos bancos, em conta corrente a juros e, a partir daí, possivelmente o capital seria parcialmente reintroduzido no mercado, especialmente pelos financiamentos a tantos empreendimentos que se faziam mediante a concessão de crédito na praça.

Além de se configurar num negócio atrativo aos investimentos capitalistas, a atividade seguradora ainda seria o reflexo, em certa medida, de algumas das transformações por que passava a sociedade brasileira durante quase todo o século XIX. A abertura dos portos brasileiros às transações comerciais com as nações aliadas a Portugal, ou mesmo o impacto que a instalação da Corte na província do Rio de Janeiro exerceria sobre a economia coeva, principalmente a economia da região centro-sul da então colônia; todas essas mudanças seriam absorvidas pelo setor segurador, que daria respostas às necessidades criadas pela nova conjuntura político-econômica do início do século.

Nesse sentido, não fora coincidência o fato das primeiras seguradoras brasileiras terem surgido durante a primeira década do oitocentos, especificamente logo da chegada e da instalação da Corte na nova sede do Reino. Muito embora o seguro, ao que tudo indica, já se constituísse numa prática comercial largamente difundida na colônia - e de igual forma em tantas outras praças comerciais espalhadas por todo o mundo -, contratado por negociantes ou grupos de negociantes brasileiros, particulares, ou estipulado junto às 
companhias estrangeiras; D. João somente autorizaria o estabelecimento, ou a incorporação, e o funcionamento das primeiras companhias de seguros organizadas por negociantes nacionais, depois de aportado na capitania da Bahia. Explica-se essas primeiras concessões não só porque a antiga sede do Império português estaria praticamente incomunicável com o restante de suas possessões ultramarinas, e a tarefa de então seria a de reerguer a monarquia lusitana que acabara de sofrer um severo golpe; mas também porque a atividade seguradora era por si muito lucrativa, e sua prática nas praças comerciais da colônia, ao mesmo tempo em que evitaria o vazamento de grandes fortunas pagas em prêmios às companhias seguradoras de países estrangeiros, evitaria os transtornos que provavelmente emergiriam em decorrência da contratação de seguros em terras distantes ${ }^{95}$.

Além disso, os seguros deveriam estar à disposição dos negociantes que se dispusessem a enfrentar os riscos inerentes a qualquer empreendimento marítimo que, como vimos, passou a ser incentivado largamente. A rentabilidade das transações comerciais, sobre as quais se depositavam muitas esperanças, dependeria do amparo do setor segurador em todas as etapas do negócio. Em especial o tráfico transatlântico de escravos, ele se intensificou em decorrência da instalação da Corte no Rio de Janeiro e também porque a região do Vale do Paraíba foi abrigando cada vez mais plantações de café, produto destinado quase que exclusivamente á exportação. Os negociantes envolvidos no comércio negreiro, cujos empreendimentos demandavam a presença dos seguros como alternativa às perdas das embarcações, dos gêneros apropriados ao escambo na costa da África, e também da mercadoria cativa a ser trazida de volta ao Brasil; invariavelmente teriam seus nomes envolvidos, de igual forma, nos quadros de acionistas ou nos quadros diretivos das companhias seguradoras cariocas, pelo menos as que atuaram na província durante os trinta primeiros anos do oitocentos. Isto porque o setor segurador se constituía, de fato, num ramo muito atraente aos investimentos dos capitais circulantes no mercado, ou porque encaravam esses investimentos como uma maneira eficiente de minorar os custos das viagens ao continente africano.

À medida que se iam os anos do século XIX, ao que parece, apagava-se a figura dos seguradores particulares do cenário segurador - sempre presentes nas praças mercantis,

\footnotetext{
95 Ou porque seriam acrescidos gastos com impostos e comissões, ou porque a notícia da ocorrência do sinistro poderia chegar aos ouvidos dos seguradores antes do aviso, dentre outras situações que perturbariam a administração dos empreendimentos marítimos, cf. ALVES, Jorge Fernandes. A Difusão da técnica atuarial e as primeiras companhias de seguros no Porto (século XIX), p. 193-194.
} 
pelo que indicia as condições que vieram junto ao restabelecimento da Casa de Seguros de Lisboa $^{96}$, em meados do século XVIII -, e as companhias, boa parte delas por ações, disseminavam-se pelo mercado como forma organizada de se extrair os interesses provenientes das contratações dos riscos. Portanto, a maior ou menor lucratividade que poderiam obter das subscrições das apólices, como em toda empresa capitalista, estaria diretamente condicionada à forma como se dispunham estruturalmente e como organizavam seus negócios.

Ao que parece, nos momentos em que a economia coeva suportasse um mercado propício aos investimentos no setor de seguros, ou em outras palavras, nos momentos em que os negociantes vislumbrassem alguma oportunidade nesse setor, que lhes fosse favorável à conversão de seus capitais; então, esses bem poderiam ser momentos em que se desejasse o incremento do capital social das companhias já existentes, ou que houvesse espaço à organização de novas seguradoras. Ou porque havia carência de oferta de seguros a um determinado risco - em decorrência, por exemplo, do recrudescimento de determinada atividade mercantil, como fora o caso do comércio marítimo nos primeiros anos do século XIX -, ou porque, no caminhar da conjuntura político-econômica do oitocentos, novos riscos, e portanto novas necessidades, foram promovendo os obstáculos a novos empreendimentos comerciais - como fora o caso do transporte por vias terrestres, na segunda metade do século -; ao que tudo indica, o negociante, ou o grupo de negociantes predispostos a atuarem no ramo dos seguros, remeteriam ao governo imperial uma sugestão de Estatutos da companhia que desejassem fundar, peticionando pela sua aprovação.

Embora nem todas as companhias de seguros que atuaram na praça comercial da província do Rio de Janeiro, e de forma geral no Brasil, durante o período compreendido pelos anos de 1808-1889, estivessem autorizadas a funcionar pela chancela do governo, em regra, o caminho para a oficialização seria o de pleitear seu reconhecimento junto ao poder imperial. Se os Estatutos sugeridos pelos negociantes estivessem de acordo com a legislação do Estado, seriam aprovados sem maiores problemas. Caso houvesse algum artigo contrário às regras, invariavelmente seriam alterados antes de serem aprovados.

Durante todo o Império do Brasil muitas companhias seguradoras tiveram suas incorporações autorizadas mediante os decretos do Poder Executivo. Por esses documentos não só se conheciam os primeiros Estatutos aprovados juntamente com a autorização

\footnotetext{
${ }^{96}$ Cf. Alvará de 29 de agosto de 1758.
} 
concedida ao estabelecimento de cada companhia, como também suas alterações que, ao longo do tempo, tornar-se-iam necessárias tanto para se adequarem à legislação, em constante transformação, como para se conformarem às inconstantes demandas do mercado. Em regra, os Estatutos de cada seguradora iam em anexo ao texto de cada um desses tipos de decreto, e traziam consigo as disposições que deveriam ser estritamente observadas pelos negociantes durante todo o tempo de vida da companhia. Caso se desse o contrário, correriam o risco eles próprios da cassação da autorização que lhes concederam o direito de atuação no mercado.

Além dos dispositivos que revelavam a estrutura organizacional - e portanto de poder -, de cada companhia, havia aqueles que limitavam o valor das contratações a uma determinada parcela do capital social; aqueles que delimitavam os ramos de seguros sobre os quais a seguradora atuaria no mercado; outros que previam a resolução de qualquer dúvida ou conflito que porventura emergisse da relação contratual entre segurador e segurado; dentre outros que conjuntamente descortinariam ao menos uma noção de como fora operado o negócio dos seguros no decorrer do século XIX. Logo no início do oitocentos, assim que D. João aportou em águas baianas, e cerca de um mês após ter ordenado a abertura dos portos brasileiros ao livre comércio com as nações estrangeiras, foi concedida a permissão real para que alguns negociantes estabelecidos na praça mercantil daquela província pudessem incorporar a primeira companhia seguradora do Brasil. Com o Decreto de autorização, ao invés dos estatutos, iam as Condições. Trocavase o nome, mas semelhantemente ao que ocorreu em toda a vigência do Império brasileiro, as referidas Condições, assim como os estatutos das mais companhias, prescreviam a organização estrutural da seguradora, bem como delimitavam a realização de seus negócios e, de uma maneira geral, sua atuação no mercado.

\subsection{As Primeiras companhias de seguros e o negócio do tráfico}

O Decreto de 24 de fevereiro de 1808 foi por onde o príncipe regente prestou seu imperial beneplácito ao estabelecimento da Companhia de Seguros Boa Fé, na capitania da Bahia. Havia considerado afirmativamente a representação que lhe fizeram subir os comerciantes daquela praça comercial, que diziam ser "a falta que nela há de 
seguradores"97 o principal impeditivo ao desenvolvimento do comércio marítimo. Os seguros, ou a presença de quem se dispusesse a garantir os riscos a que se lançavam os empreendimentos marítimos, ao que parece, "nas críticas e atuais [1808] circunstâncias contribuam [contribuiriam] a animar as especulações e tentativas do comércio; e querendo sobre este importante objeto dar alguma providência em utilidade do mesmo comércio", conformou-se em conceder aos negociantes da capitania baiana a necessária autorização para que incorporassem esta companhia de seguradores.

A Boa Fé foi estabelecida na praça comercial da capitania baiana, portanto, mas a companhia não estaria autorizada a funcionar no comércio como bem entendesse. Pelo contrário, o Decreto trazia consigo as Condições que deveriam ser por ela observadas quando se propusesse a contratar os seguros. Eram, no total, 14 artigos que regulavam, basicamente, a estrutura da seguradora, suas relações internas e as que deveriam manter com os segurados. Estes artigos, por exemplo, determinaram que o fundo da Companhia seria constituído pelo montante de "400:000\$000 [quatrocentos contos de reis] divididos em ações de 800\$000 [oitocentos mil reis] cada uma". O conhecimento do número de ações obtidas pelos negociantes torna-se importante por pelo menos dois motivos: um, ninguém poderia ser acionista caso possuísse menos de 05 (art. 2º); e, segundo, a responsabilidade de cada acionista seria medida proporcionalmente ao seus respectivos quinhões do capital da companhia, expressos no valor e na quantidade de suas respectivas ações $\left(\operatorname{art} .4^{\circ}\right)$. Isso quer dizer que, caso "ao tempo do pagamento de qualquer perda" não houvesse dinheiro para sua satisfação, os caixas convocariam os sócios a completar o valor do débito na proporção de suas ações. Aquele que não o fizesse dentro de oito dias, estaria “desde logo expulso da sociedade, e sem ação alguma dos lucros que até aquele tempo lhe possam pertencer; ficando sempre obrigados aos riscos pendentes, porque desde então será havida sem vigor algum a sua assinatura, como se não existisse.” (art. 11). Por outro lado, aos sócios era permitido que se retirassem da sociedade, conquanto que o fizessem de modo a garantir a solvabilidade da Companhia (art. 12). Como se vê, a própria estrutura da seguradora, e principalmente as relações entre os sócios, estaria moldada de modo a evitar sua inadimplência junto aos credores e à massa de segurados e, dessa forma, evitar que danos mais drásticos acometessem o corpo do comércio. Tanto é assim que, em caso de "morte natural ou civil", os herdeiros dos acionistas não poderiam reclamar a herança, pois ela ainda responderia pelos riscos pendentes $\left(\operatorname{art.} 6^{\circ}\right)$.

${ }^{97}$ Cf. Decreto de 24 de fevereiro de 1808. Esta citação, bem como as que a seguir comporão a narrativa deste e dos próximos parágrafos, foram todas extraídas do texto do documento de 1808 . 
Uma vez estabelecida a companhia, seus sócios nomeariam três "diretores ou administradores", que seriam os responsáveis pela gestão dos negócios. Eles deveriam organizá-la administrativa e financeiramente, e também representá-la no mercado. De fato, a função dos sócios administradores, ou caixas, consistiria em tomar os seguros; cobrar os prêmios - cujas formas e épocas do pagamento deveriam ser livremente "convencionados entre os diretores e segurados" (art. 13) -; assinar as apólices em nome da companhia; e pagar as perdas decorrentes dos sinistros (art. $8^{\circ}$ ); sendo-lhes justos, por todo esse trabalho, os "cinco por cento das importâncias do prêmio", a ser rateado entre eles (art. $9^{\circ}$ ).

Alguns meses depois, já estabelecido na província do Rio de Janeiro, D. João aprovou os nomes que os acionistas da Boa Fé sugeriram para a ocupação dos cargos de diretores da empresa, e o fez mediante a publicação de sua Carta Régia de 9 de junho de 1808, destinada ao Conde da Ponte, à época Governador e Capitão General da capitania da Bahia. No mesmo ano, também da cidade do Rio de Janeiro, o então príncipe regente viu nascer a segunda seguradora brasileira. Ao que tudo indica, fora o próprio Conde da Ponte que aprovara "a criação e estabelecimento de uma nova Companhia de Seguros", a Conceito Público, também na Bahia, e que comunicou o feito a D. João por meio de uma carta datada do dia 6 de setembro de 1808. Por esta carta foi-lhe dado conhecimento dos motivos que levaram o então Governador a atender ao pedido dos negociantes daquela praça comercial, e também das Condições a serem observadas pelos futuros seguradores quando se dispusessem a iniciar as contratações dos riscos autorizados.

Parecia que o estabelecimento de mais uma companhia de seguros na Bahia fora de suma importância ao desenvolvimento do comércio marítimo daquela região. E, por isso, diante do que lhe havia em mãos, e "pelos muitos proveitos que hão de resultar aos meus fieis vassalos, à utilidade e estabilidade do comércio desse país, e ao aumento da riqueza e prosperidade nacional", o príncipe aprovou o "referido estabelecimento, e as condições propostas" quando da publicação da Carta Régia de 24 de outubro de 1808, cerca de um mês e meio, portanto, após ser informado da iniciativa do Conde ${ }^{98}$.

O país só conheceria a terceira companhia de seguros incorporada por negociantes brasileiros cerca de ano e meio depois de decorridas as atividades dos comerciantes baianos nesse ramo do mercado. A mesma conjuntura que permeara o contexto de criação

\footnotetext{
${ }^{98}$ Cf. Carta Régia de 24 de outubro de 1808. As citações deste e do parágrafo anterior são excertos extraídos do referido documento. O que nos falta para uma análise mais rigorosa do funcionamento dos negócios da Companhia de Seguros Conceito Público, no entanto, são justamente as suas Condições. Elas não foram publicadas como parte integrante da Carta Régia de outubro de 1808. Por isso, a exposição de maiores detalhes sobre a organização e a representação dessa companhia no comércio resta-nos prejudicada.
} 
das duas primeiras seguradoras permearia, de algum modo, o nascimento da Companhia de Seguros Indemnidade, no Rio de Janeiro. A abertura dos portos brasileiros às transações comerciais com as nações estrangeiras, ao que parece, impactaria positivamente sobre a intensidade do comércio nacional. Mas, especialmente para o caso da região centro-sul da colônia, a escolha da capitania como nova sede do governo do Império ultramarino português, e a consequente instalação da Corte na cidade do Rio de Janeiro, tudo isso parece ter concorrido para o recrudescimento dos embarques e desembarques que presenciara o porto carioca, e para que os negociantes ali estabelecidos se sentissem instigados a requererem ao príncipe regente a autorização necessária para a incorporação de uma seguradora nessa mesma praça comercial. Parecia não haver dúvida de que a petição conspirava em "benefício, adiantamento, segurança do comércio e navegação",99, o que levou D. João a resolvê-la favoravelmente ao interesses do corpo mercantil, em fevereiro de 1810.

Esta Resolução foi a que confirmou o parecer emitido pela Real Junta do Comércio, Agricultura, Fábricas e Navegação sobre o requerimento dos negociantes da praça do Rio de Janeiro, em que pediam o estabelecimento da Companhia de Seguros Indemnidade. Ao contrário da Carta Régia de 24 de outubro de 1808, que aprovou a criação da Companhia Conceito Público, na capitania da Bahia, e semelhantemente ao Decreto de 24 de fevereiro de 1808, que aprovou o estabelecimento da Companhia de Seguros Boa Fé, também na Bahia, a presente Resolução de Consulta resgata as Condições sobre as quais a Real Junta emitiu seu parecer.

As Condições a que deveriam observar a companhia de seguros Indemnidade foram compostas por 15 artigos que, como no caso da Boa Fé, prescreviam sobre a organização e o negócio da companhia e, embora nenhum deles mencionasse expressamente a divisão de seu capital em ações - 500:000\$000 (quinhentos contos de reis) - esta sociedade de seguradores foi, de fato, uma sociedade de acionistas. A leitura desse documento nos revela que houve pelo menos um requisito necessário ao início do empreendimento. A Indemnidade, por certo, somente poderia principiar suas atividades mediante $\mathrm{o}$ preenchimento do "fundo que a constitui" - 600:000\$000 (seiscentos contos de reis), conforme estipulado pela Real Junta -, sobre o qual os negociantes estariam obrigados solidariamente no caso de falência de um dos sócios (art. $1^{\circ}$ das Condições, e parecer da

\footnotetext{
${ }^{99}$ Cf. Resolução $\mathrm{n}^{\circ} 5$, de 5 de fevereiro de 1810 . Esta citação, bem como as que compõem os parágrafos a seguir, que dizem respeito aos negócios da Companhia de Seguros Indemnidade, são todas trechos retirados do referido documento.
} 
Real Junta). Uma vez preenchido esse fundo, portanto, os acionistas - admitidos como tais somente aqueles que contassem com pelo menos 04 ações (art. $1^{\circ}$ ) - reunir-se-iam para a nomeação de três Diretores, dos quais um seria o Caixa, todos convocados a reger os negócios da companhia (art. 14).

A Indemnidade, então constituída, estaria apta a contratar seguros contra os riscos marítimos mediante apólices pactuadas livremente com os segurados; e descontar letras "que tenham pelo menos três boas firmas" (art. $6^{\circ}$ ). Para tudo isso, o Diretor-Caixa ficaria encarregado pela cobrança dos prêmios dos seguros e pelo "pagamento das perdas e avarias legalizadas e aprovadas pelos outros dois Diretores" (art. $8^{\circ}$ ); também ficaria a seu cargo a convocação de todos os sócios para que participassem da sessão geral a ser realizada "no último de dezembro de cada ano", ocasião em que lhes seria apresentado um "balanço do estado da Companhia", e onde tomaria os dividendos o seu lugar, "de modo que nunca fique deteriorado o crédito da Companhia na diminuição dos fundos a que devem sempre responder os riscos pendentes (...)" (art. $\left.8^{\circ}\right)$.

Em contrapartida aos trabalhos prestados, os dois Diretores e o Caixa seriam remunerados com a quantia de 1:800\$000 (um conto e oitocentos mil reis). Porém, este valor conviria apenas para o primeiro ano de funcionamento da seguradora, pois a partir do segundo receberiam "somente seis por cento do prêmio que granjearem" (art. 9º). Todos os três, particularmente, eram responsáveis “in solidum" pelo que de valor havia no cofre da Indemnidade (art. $7^{\circ}$ ); e conjuntamente com os demais sócios, poderiam perder o "lucro vencido", responder pela perda proveniente dos "acontecimentos adversos", bem como pagar os "juros da demora", caso não entrassem ao caixa, se as circunstâncias assim o exigissem, com as parcelas faltantes à composição do capital da companhia (art. $3^{\circ}$ ). Os acionistas, por outro lado, responderiam "in solidum" na medida do valor de suas ações, e também "por tudo o mais que expuserem a riscos" (art. $2^{\circ}$ ). A inobservância destas Condições, assim como nos casos de morte natural ou civil, poderia repercutir na perda da qualidade de sócio do faltante e, sendo assim, nem ele poderia pedir as contas, nem seus herdeiros poderiam reclamar a herança, uma vez que estaria à mercê da liquidação dos riscos pendentes (art. $5^{\circ}$ ). A outra possibilidade de abandono da sociedade seria a voluntária: o sócio que assim desejasse se retirar deveria comunicar aos Diretores sua decisão, conquanto que em tempo hábil - seis meses - para se "prover a substituição da sua falta" (art. 10). De um modo ou de outro, como se vê, estariam sempre presentes os cuidados para que fossem evitados maiores prejuízos ao corpo do comércio, provocados 
pela má administração da empresa e pelo consequente inadimplemento de seus credores; todos eles traduzidos nos artigos que limitavam ou condicionavam as ações da seguradora como um todo, e dos seus acionistas em particular.

Até a publicação do Alvará de 5 de maio de 1810, que liberou o valor dos prêmios à livre estipulação dos contratantes do câmbio marítimo, três companhias de seguros, incorporadas por negociantes nacionais, foram estabelecidas e começaram a funcionar no país. Ao que tudo indica, esse fora o saldo do setor quando do fechamento da primeira década do oitocentos. Por outro lado, não tardaria muito até que novas seguradoras fossem instaladas e passassem a concorrer entre si pelas mesmas oportunidades oferecidas pelo mercado. Um mercado, diga-se de passagem, que bem poderia render bons frutos aos negociantes que colocassem seus cabedais à disposição dos comerciantes, dos capitalistas, dos proprietários, enfim, que inevitavelmente procurariam se precaver dos perigos que, possivelmente, afetariam a rentabilidade de seus empreendimentos.

De fato, se a maior ou menor densidade da atividade seguradora pode ser compreendida, de certo modo, como um reflexo das dificuldades ou da prosperidade pela qual atravessa uma sociedade numa dada época, denota-se, de igual modo, que o recrudescimento do comércio marítimo que se viu durante esses primeiros anos da chegada da Corte portuguesa à sua colônia americana, e a consequente intensificação de um de seus ramos mais lucrativos e atraentes aos investimentos capitalistas - o tráfico transatlântico de escravos -; tudo isso deve ter contribuído para aumentar a contratação dos seguros e, por conseguinte, possivelmente ocasionou o aumento do número de petições junto ao poder oficial, de negociantes suplicando a autorização para a incorporação de mais e mais companhias seguradoras, pelo menos na praça comercial do Rio de Janeiro.

Nesse período que correspondeu ao primeiro terço do século XIX, havia notícias da existência ou do funcionamento de cerca de dez companhias de seguros que, ao que parece, em sua maioria, ou em sua totalidade, se dedicaram, sobretudo, às negociações em torno dos riscos provenientes do transporte marítimo. Foi na segunda década do século que surgiram as cinco primeiras seguradoras. A Companhia de Seguros Marítimos Indemnidade despontou logo no ano de 1810, sendo a primeira a ser estabelecida na praça mercantil do Rio de Janeiro, e a terceira autorizada a funcionar na então colônia portuguesa, conforme visto. A ela seguiram, também na praça carioca, a Companhia de Seguros Providente (1814), a Permanente (1816), a Probidade (1817), a Tranquilidade (1818), e a Restauradora (1820). A década seguinte conheceu outras quatro, inclusive a 
Associação de Seguros Mútuos Brasileiros - também denominada Sociedade de Seguros Mútuos Brasileiros -, única sociedade mútua dentre tantas companhias por ações, autorizada em 1828, mas que não teria chegado a funcionar. A mutualidade entre os negociantes permitiria que os donos das embarcações, que porventura estivessem dispostos a contratar seus riscos com esta sociedade, fossem ao mesmo tempo segurados e seguradores de seus negócios, o que poderia contribuir para minorar o gasto com o seguro, indispensável aos empreendimentos marítimos, já que os lucros seriam divididos, ao fim, entre todos os associados. As outras quatro empresas fundadas na década de 1820 foram a Companhia de Seguros Segurança (1827), a Retribuição (1827), e a Companhia de Seguros Concordia $(1828)^{100}$.

Dessas nove companhias de seguros, se se desconsiderar a Associação de Seguros Mútuos Brasileiros, que não teria funcionado, em pelo menos sete delas o capital proveniente do tráfico transatlântico de escravos - e que a este comércio retornaria na forma de novos investimentos -, ou em outros termos, os interesses do tráfico negreiro, estariam presentes $^{101}$. Traficantes donos de grandes fortunas estiveram arrolados dentre os acionistas das seguradoras, dentre seus credores até, e chegaram mesmo a ter seus nomes relacionados, juntamente com o de tantos outros negociantes, na ocupação dos cargos diretivos das companhias de seguros, pelo menos as que se encontraram em funcionamento no primeiro terço do século XIX.

Fora o que ocorreu na administração da Companhia de Seguros Marítimos Indemnidade, por exemplo, quando em 1816 dentre os nomes que fizeram sua diretoria estiveram presentes o de Mariano José Pereira da Fonseca, de Manoel Moreira de Figueiredo e o de José Caetano Gómez. Todos eles negociantes cujos investimentos no

\footnotetext{
${ }^{100}$ Para maiores informações sobre as companhias de seguros existentes nesse período, cf. Anexo 2, p. 195. Para o debate coevo em torno do pedido de autorização da Associação de Seguros Mútuos Brasileiros feito junto à Real Junta do Comércio, Agricultura, Fábricas e Navegação do Rio de Janeiro, cf. BOHRER, Saulo Santiago, O "seguro" morreu de velho. Para a informação que diz não ter funcionado a Associação de Seguros Mútuos Brasileiros, mesmo tendo sido autorizada, cf. BOHRER, Saulo Santiago, "Interesses Seguros", p. 66.

${ }^{101}$ Manolo Florentino chegou a esse número após "O cruzamento dos nomes dos consignatários de escravos, fornecidos pelos jornais de época, com as listagens econômicas e financeiras do Rio de Janeiro (...)”, cf. FLORENTINO, Manolo, Em Costas negras, p. 128. A influência dos traficantes de escravos nas companhias de seguros também pode ser constatada por Saulo Santiago Bohrer. Em nota, o autor afirma ter comparado "as assinaturas nos pareceres dos diretores das seguradoras com a listagem dos principais comerciantes de escravos presente no apêndice do livro de Manolo Florentino", cf. BOHRER, Saulo Santiago, "seguro" morreu de velho, p. 16. O livro de Florentino ao qual se refere é a obra Em Costas negras: uma história do tráfico de escravos entre a África e o Rio de Janeiro (séculos XVIII e XIX), e o apêndice mencionado por Bohrer é o de $\mathrm{n}^{\circ} 26$, que pode ser localizado nas páginas 254-256. E os pareceres assinados pelos diretores das companhias de seguros podem ser localizados no Fundo da Real Junta de Comércio, Agricultura, Fábricas e Navegação, guardada pelo Arquivo Nacional do Rio de Janeiro.
} 
comércio negreiro eram bastante significativos. Outro exemplo de seguradora que abrigou os interesses do tráfico foi a Companhia de Seguros Providente. A empresa fora fundada em 1814 e dos seus 32 acionistas alguns foram empregadores de vultosos cabedais no comércio transatlântico de escravos. Foram os casos de Manoel Caetano Pinto, que além de negociante chegara a ser deputado da Real Junta de Comércio, Agricultura, Fábricas e Navegação, e membro da diretoria do Banco do Brasil no ano de 1809; José Gomes Barroso e José Gomes Barroso Filho, membros de uma família reconhecida por seu envolvimento no trato negreiro e que no período compreendido entre os anos de $1811 \mathrm{e}$ 1830 foram e voltaram da costa africana 46 vezes; Manoel Pinheiro Guimarães, de igual modo membro de uma família reconhecida por seu envolvimento no tráfico - realizou 32 viagens à África entre 1811 e 1830; e José Ignácio Vaz Vieira, responsável por 33 desembarques de cativos africanos na costa brasileira durante os primeiros trinta anos do oitocentos. Além desses nomes, as figuras de João Gomes Barroso, João Martins Lourenço Vianna e José Henrique Pessoa, todos traficantes de escravos, poderiam ser encontradas no escritório da diretoria da companhia, em algum momento em que esteve em funcionamento. Outro traficante, Elias Antônio Lopes, chegou a ser credor das seguradoras Providente e da Indemnidade, além de ter ocupado cargos em órgãos do estado. Quando, em 1810, alguns sócios desta última companhia suplicaram a D. João para que o nomeasse Corretor e Provedor dos seguros, ele já era deputado da Real Junta do Comércio e prestigiado negociante estabelecido na praça do Rio de Janeiro. O parecer emitido por seus pares foi favorável à sua nomeação, pois era "certo que o mesmo Deputado Elias Antônio Lopes é benemérito do ofício, e de qualquer graça que Vossa Alteza Real se digne de lhe conferir" ${ }^{\prime 102}$.

\footnotetext{
${ }^{102}$ Cf. BOHRER, Saulo Santiago, "Interesses Seguros", p. 52. Os nomes de traficantes imiscuídos dentre os que compuseram o quadro diretivo da Companhia de Seguros Marítimos Indemnidade constavam dos documentos guardados na Caixa 435, Pacote I, do Fundo da Real Junta de Comércio, Agricultura, Fábricas e Navegação (Arquivo Nacional do Rio de Janeiro), conforme referencia o autor. Por outro lado, para o caso da Companhia de Seguros Providente, Bohrer organizou os nomes de seus acionistas na tabela de ${ }^{\circ} 5$ intitulada "Relação de acionistas da Companhia Providente com o Senado da Câmara e os Negociantes Matriculados na Praça de Comércio do Rio de Janeiro". A listagem dos documentos utilizados para a elaboração da relação é referenciada na própria tabela, cf. BOHRER, Saulo Santiago, op. cit., p. 53-54. As biografias dos traficantes envolvidos nos negócios das companhias de seguros a que ora são dedicadas poucas linhas podem ser encontradas de forma mais detalhada em BOHRER, Saulo Santiago, op. cit., p. 55-56. A respeito da biografia de Elias Antônio Lopes, em especial, cf. BOHRER, Saulo Santiago, O "seguro" morreu de velho, p. 03; FLORENTINO, Manolo, op. cit., p. 194; Resolução de Consulta da Real Junta do Comércio, Agricultura, Fábricas e Navegação de 5 de fevereiro de 1810, documento do qual foi extraída a citação.
} 


\section{Os Números do mercado.}

Ao longo de todo o século XIX, inúmeras companhias de seguros coabitariam a praça comercial da província do Rio de Janeiro. Ou porque a demanda por seguros constantemente superava a oferta de capital disposto a garantir o patrimônio dos negociantes, ou dos proprietários, que desejassem se arriscar no comércio, ou porque novos riscos, provenientes de novas atividades empresariais, vinham criando novas necessidades cujas satisfações condicionariam o sucesso dos empreendimentos; o fato era que durante o Império do Brasil, a conjuntura político-econômica que o acompanhou parece ter sido, em geral, favorável aos seguros, e frequentemente ofereceria novas oportunidades aos investimentos capitalistas nesse setor. Ainda que durante os primeiros anos do século poucas companhias foram estabelecidas na praça do Rio de Janeiro, essa estagnação, ou esse baixo índice de crescimento do mercado segurador carioca, ao que tudo indica não refletiu a realidade de todos os oitenta anos, contados a partir da chegada da Corte ao Brasil, e que se estenderia até o fim do reinado de D. Pedro II (1808-1889).

Talvez essa debilidade do mercado fora mais característica da primeira metade do século XIX, pois, dentre todas as informações condizentes à existência das seguradoras, revelou-se que somente $16,78 \%$ delas começaram a subscrever suas apólices nesses primeiros cinquenta anos do oitocentos. Aí, não são raras as vezes que a incorporação de uma companhia é precedida de um intervalo de tempo razoavelmente longo, podendo alcançar mesmo oito anos, a contar do nascimento da última seguradora. Na segunda metade do século, ao contrário, seria evidente a maior concentração dessas empresas. As informações que certificaram a existência de companhias de seguros na praça comercial do Rio de Janeiro a partir de 1850 , indicaram que mais de $80 \%$ delas deram início às suas operações durante os cerca de quarenta anos que precederam a queda do Império brasileiro.

A conjuntura do período que se iniciaria nos meados da década de 1860, contudo, foi amparando o surgimento de um número cada vez maior de companhias de seguros, seja nacionais, seja estrangeiras. Sobretudo a década de 1870 (1871-1880) seria muito favorável ao aparecimento de um terço de todas as 143 companhias que se estabeleceram na província do Rio de Janeiro durante os anos compreendidos entre 1808 e 1889. Comparando-se com as demais décadas do século, nota-se que a de 1870 foi a que trouxe consigo a maior quantidade de seguradoras incorporadas. É o que mostra a Tabela 1, a seguir, que organiza os números absolutos e relativos reveladores do montante de companhias que foram se estabelecendo em cada decênio do período averiguado. 


\section{Tabela 1: Companhias de seguros estabelecidas em cada década do período 1808-1889.}

\begin{tabular}{|c|r|r|}
\hline Década & Companhias de Seguros & \% sobre o total \\
\hline $\mathbf{1 8 0 8 - 1 8 2 0}$ & 06 & $4,19 \%$ \\
\hline $\mathbf{1 8 2 1 - 1 8 3 0}$ & 04 & $2,8 \%$ \\
\hline $\mathbf{1 8 3 1 - 1 8 4 0}$ & 02 & $1,4 \%$ \\
\hline $\mathbf{1 8 4 1 - 1 8 5 0}$ & 12 & $8,39 \%$ \\
\hline $\mathbf{1 8 5 1 - 1 8 6 0}$ & 29 & $20,28 \%$ \\
\hline $\mathbf{1 8 6 1 - 1 8 7 0}$ & 21 & $14,69 \%$ \\
\hline $\mathbf{1 8 7 1 - 1 8 8 0}$ & 43 & $30,07 \%$ \\
\hline $\mathbf{1 8 8 1 - 1 8 8 9}$ & 26 & $18,18 \%$ \\
\hline Total & 143 & $100 \%$ \\
\hline
\end{tabular}

Fonte: Quadro Companhias de Seguros em funcionamento na Província do Rio de Janeiro (1808-1889), cf. Anexo 2.

Todos esses números puderam ser conhecidos pelos dados que vão organizados no Quadro Companhias de Seguros em funcionamento na Província do Rio de Janeiro (1808$1889)^{103}$. Ele foi dividido em campos que, além de nos informar a quantidade e os nomes das companhias autorizadas a funcionar - ou que atuaram - na praça comercial desta província, revelam também os locais onde elas estariam sediadas, os riscos sobre os quais estariam autorizadas a contratar, e, por fim, o período que exerceram suas atividades. E é sobre este último campo, denominado 'funcionamento', que devem ser levantadas tantas considerações quantas forem necessárias ao seu esclarecimento, justamente pelas dificuldades enfrentadas quando da organização dos dados a ele subordinados, e que provieram da coleta de uma variedade razoável de fontes disponíveis. Não tanto porque as informações fornecidas por uma e outra fonte discordassem entre si, mas porque as datas extraídas de cada uma delas noticiariam algo além da "certeza" tão procurada.

O campo posto em evidência está subdividido em duas colunas, a primeira denominada ' $1^{\mathrm{a}}$ data', e a segunda, chamada de 'Data final'. Sob cada uma delas, respectivamente, foram organizadas as primeiras e as últimas datas condizentes a cada companhia de seguros. Ou seja, as primeiras e as últimas informações que, de um modo ou de outro, noticiaram a existência de cada seguradora. Essas datas poderiam ser as que forneceram os decretos publicados pelo Poder Executivo, e que puderam ser localizados na Coleção das Leis do Império do Brasil (1808-1889): especialmente aqueles que autorizaram o funcionamento dessas empresas; os que aprovaram os Estatutos sob os quais os negociantes deveriam organizá-las, e que ao mesmo tempo baixaram as regras que

${ }^{103}$ Cf. Anexo 2, p. 195. 
deveriam ser observadas quando se dispusessem a contratar os seguros; ou mesmo os decretos que reformaram estes Estatutos, seja para adequá-los a uma nova legislação, seja para adequá-los a novas exigências do mercado. Por um lado, esses documentos permitemnos conhecer as datas em que essas seguradoras foram incorporadas, ou estabelecidas, na praça comercial do Rio de Janeiro; as datas em que sofreriam alguma modificação na sua estrutura jurídica ou organizacional; as que denunciaram, de igual modo, as concessões ou as limitações à contratação dos seguros; e, em raras ocasiões, as datas em que tiveram cassadas suas autorizações para o funcionamento.

Por outro lado, todas essas informações devem ser interpretadas restritivamente. Isso quer dizer que todas as datas informadas pelos Decretos foram consideradas de modo a não revelar nada além do que realmente diziam. Nesse sentido, um documento que autorizasse a incorporação de uma companhia em determinada data, por exemplo, não poderia garantir, por si próprio, que essa mesma companhia somente passou a atuar no mercado depois de beneficiada pela concessão imperial. Os Decretos autorizadores, como se vê, não noticiaram necessariamente os nascimentos das companhias. Muitas delas já estariam atuando no mercado antes mesmo de publicada a aprovação de seus Estatutos. Outras, mesmo depois de autorizadas, ainda se demorariam a organizar seus negócios. E, ainda, haveria aquelas que passariam toda sua existência sem que pleiteassem qualquer oficialização para suas operações.

Se dos Decretos foram extraídas as informações correspondentes à ' 1 a data' em que fora noticiada a existência de uma determinada companhia, portanto, temos de considerar que continuamos a desconhecer o verdadeiro paradeiro da seguradora: se já funcionava antes mesmo da publicação de sua autorização, ou se somente foi incorporada muito tempo depois dessa concessão do poder imperial, enfim. Mas, apesar disso, essas informações compuseram a primeira coluna do campo ‘funcionamento' do Quadro, e constituíram o ponto de partida para a averiguação do período que cada uma das companhias chegou a contratar seus seguros na praça comercial do Rio de Janeiro.

Muitas dessas dúvidas e incertezas herdadas unicamente das informações constantes dos Decretos do Poder Executivo, no entanto, puderam ser resolvidas pelas informações coletadas de outros corpos documentais, como foi o caso do Almanak administrativo, mercantil e industrial do Rio de Janeiro - também conhecido como Almanak Laemmert - publicado na província do Rio de Janeiro durante os anos compreendidos entre 1844 e 1889 . Ao que tudo indica, esta foi uma fonte que refletiu, em 
comparação à consulta à Coleção das Leis do Império do Brasil (1808-1889), mais pormenorizadamente a existência das companhias de seguros que atuaram na cidade do Rio de Janeiro e em seus arredores. Os dados que puderam ser extraídos de cada volume do Almanak, além de terem informado os nomes das empresas, também informaram os nomes dos negociantes a elas vinculados - seja como agentes de companhias nacionais ou estrangeiras, seja compondo seus quadros diretivos, ou mesmo os quadros administrativos -; e os endereços se não de todas, pelo menos da grande maioria delas.

Cada número do periódico denunciava a conformação do mercado carioca correspondente ao ano anterior ao de sua feitura. Talvez fosse uma característica do Almanak Laemmert em especial, ou talvez ela também seja compartilhada pelos almanaques de um modo geral, mas o fato era que a veracidade das informações contidas em cada volume da obra seria garantida pela casa editorial apenas para o restante do ano em que saiu publicado. Portanto, não seria de se estranhar que os editores fizessem um esforço extraordinário para que cada número chegasse até seus assinantes, ou estivesse disponível à venda, o mais breve possível. Portanto, e como invariavelmente aconteceu, os números costumavam ser publicados logo nos primeiros meses de cada ano, para que os consulentes usufruíssem por mais tempo das informações trazidas pelo Almanak.

Mas para que tudo isso fosse possível, os editores enviariam, ao longo do ano, correspondências destinadas a vários endereços da província - dentre os quais alguns situavam residências, escritórios de empresas, repartições públicas, etc. - pedindo respostas que os informassem, dentre outras notícias, a continuidade do negócio, e os nomes envolvidos nos quadros diretivo e de pessoal de cada companhia ou órgão público. Essas informações, pediam os editores, deveriam ser-lhes devolvidas o quanto antes, no mais tardar até os últimos meses do ano quando, com base nas notícias que tivessem em mãos, começariam a tecer o volume a ser publicado no ano entrante. Como se vê, o número publicado no ano de 1844 , por exemplo, fora escrito a partir das informações que noticiavam as aberturas e fechamentos de empresas, as demissões e contratações que incrementariam os quadros de cada companhia, ou os nomes que passariam a compor o pessoal das repartições, todos eles acontecimentos concernentes ao ano que o precedia, no caso, o ano de 1843. Por essa razão, e por esses fatos, é que um determinado número do Almanak Laemmert indicava, na verdade, uma conformação pretérita do mercado carioca, mas que, por outro lado, muito auxiliaria a situação de qualquer pessoa que o consultasse no seu presente. 
De todo modo, a consulta aos diversos volumes do Almanak Laemmert acabou sendo de grande serventia à elaboração do Quadro Companhias de Seguros em funcionamento na Província do Rio de Janeiro (1808-1889). Ano a ano, os volumes que circularam na cidade e arredores do Rio de Janeiro apontaram para a presença ou para a ausência das seguradoras atuantes no mercado carioca, ou simplesmente noticiaram pormenores de seus paradeiros: se acabaram de ser incorporadas, se foram liquidadas, eventuais alterações em seus quadros administrativos, ou mesmo mudança de nomes, etc. Em cada número pesquisado dessa série documental, portanto, residiria alguma possibilidade de preencher as lacunas abertas quando da organização dos dados provenientes dos Decretos do Poder Executivo. Os Decretos não serviam a noticiar o cotidiano das companhias, e sim as alterações que porventura ocorressem em suas estruturas jurídicas, ou em relação a alguns aspectos de seus negócios. O Almanak Laemmert, por outro lado, além de auxiliar o leitor a se situar na praça da província, de igual modo seria um catálogo comercial, digamos, no qual muitas empresas, independentemente de suas finalidades, prontificavam-se a propagandear as vantagens de seus negócios, aproveitando o espaço do periódico para se destacarem das outras companhias que lhe faziam concorrência no mercado carioca.

Uma e outra fonte, portanto, explicam por si mesmas os limites impostos à continuidade das informações que disponibilizaram. Essas limitações acabaram por repercutir na coleta dos dados e na organização do Quadro que serviu de matriz às análises que empreendemos sobre o mercado segurador do Rio de Janeiro. Contudo, em se tratando dos períodos de funcionamento das companhias seguradoras, neste Quadro estão arroladas todas as datas que conseguimos juntar. A partir delas, ou especificamente a partir das datas relacionadas na coluna denominada ' 1 a data', todas as 143 companhias de seguros atuantes no Rio de Janeiro, durante o período 1808-1889, foram ordenadas. A seguradora cuja existência fora noticiada em data mais antiga, precederia às demais ${ }^{104}$.

O Quadro Companhias de Seguros em funcionamento na Província do Rio de Janeiro (1808-1889), então, expõe-nos a informação bruta, preliminar. Mas, por outro lado, necessário para nos fornecer algumas respostas a questionamentos específicos sobre o

\footnotetext{
${ }^{104}$ Outras fontes, no entanto, foram utilizadas para a elaboração do Quadro Companhias de Seguros em funcionamento na Província do Rio de Janeiro (1808-1889). A Introdução desta dissertação traz uma explicação mais detalhada dos usos e limites de cada uma das fontes utilizadas para a elaboração do Quadro Companhias de Seguros em funcionamento na Província do Rio de Janeiro (1808-1889), que vai exposto no segundo anexo a este trabalho. O Anexo 3, por sua vez, traz discussões mais específicas acerca das dificuldades com que nos deparamos quando do manuseio dessas fontes, e das soluções adotadas para que todos esses problemas fossem contornados.
} 
mercado segurador, e que a seguir tentamos ilustrá-las através da apresentação de tabelas secundárias e de gráficos.

O Gráfico 1, por exemplo, foi elaborado a partir das primeiras datas em que tivemos conhecimento das companhias de seguros e, portanto, permite-nos a visualização, em números absolutos, da quantidade de seguradoras que, ano a ano, foram se estabelecendo ou operando no Rio de Janeiro. O Gráfico 2, apresentado logo em seguida, segue a mesma linha, porém identificando as companhias, se nacionais ou se estrangeiras, que paulatinamente foram conformando o mercado segurador da província.

Como pode ser percebido pela leitura do Gráfico 2, as companhias de seguros estrangeiras só começaram a despontar na praça comercial da província do Rio de Janeiro por volta dos meados da década de 1840. De fato, a primeira data que denunciou a existência logo de três companhias estrangeiras foi o ano de 1843. No entanto, há que se considerar que muito provavelmente seguradoras estrangeiras já operavam seus negócios no mercado carioca antes mesmo dessa data. Deduz-se isso porque o ano de 1844 assiste à publicação do primeiro número do Almanak Laemmert, volume que, conforme argumentado anteriormente, traria as informações referentes ao ano que o precedeu, 1843. Isso tudo pode muito bem significar que a inexistência de notícias referentes ao funcionamento de companhias estrangeiras no mercado do Rio de Janeiro nos anos anteriores a 1843 (1808-1842), muito provavelmente foi decorrente da característica das fontes disponíveis e, portanto, não refletiria a realidade da situação por que passava aquela província.

Contudo, ao que parece, os primeiros trinta anos do século XIX seriam mesmo caracterizados pela maior concentração de companhias seguradoras nacionais. E os últimos trinta anos do Império, por outro lado, faria o país conhecer o aporte sem precedentes de companhias de seguros estrangeiras dispostas a garantirem os mais diversos riscos. Talvez a conjuntura mundial de meados do século possa explicar, pelo menos sob determinados aspectos, o interesse dessas companhias pelo mercado brasileiro, ou especificamente pelas negociações que se faziam na cidade do Rio de Janeiro e em seus arredores. 
Gráfico 1: Companhias de Seguros estabelecidas na Província do Rio de Janeiro (1808-1889).

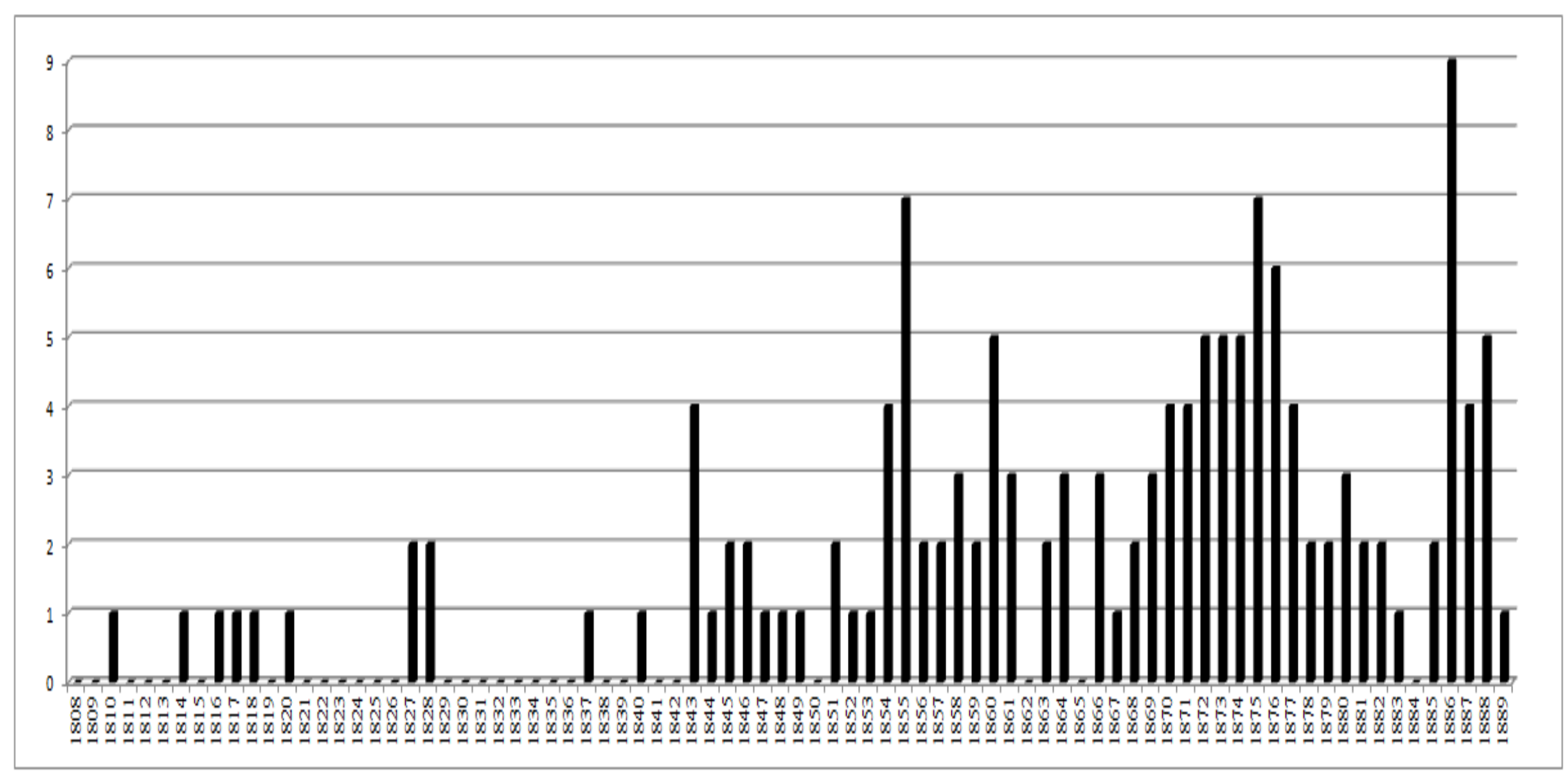

Fonte: Quadro Companhias de Seguros em funcionamento na Província do Rio de Janeiro (1808-1888), cf. Anexo 2. 
Gráfico 2: Companhias de Seguros nacionais e estrangeiras estabelecidas na Província do Rio de Janeiro (18081889).

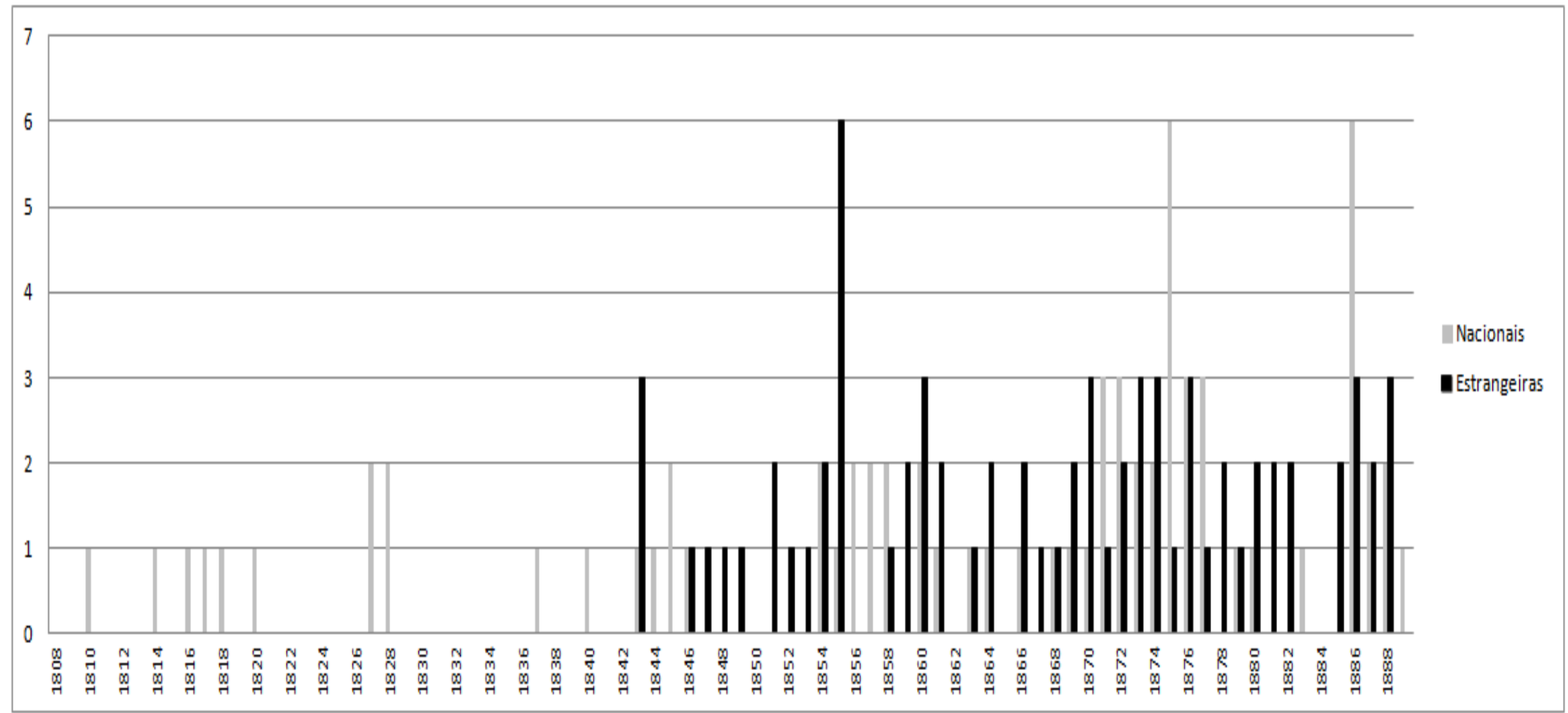

Fonte: Quadro Companhias de Seguros em funcionamento na Província do Rio de Janeiro (1808-1888), cf. Anexo 2. 
Ao que parece, os acontecimentos dessa mesma época evidenciaram o Brasil como um ator relevante no cenário econômico mundial, pelo menos quanto à sua capacidade de suprir os estoques estrangeiros com uma importante mercadoria produzida pela sua vasta agricultura. A partir dos anos da década de 1850, a produção cafeeira brasileira, que já vinha se destacando mundialmente frente à produção de outras regiões concorrentes, passa a ser responsável por cerca da metade de todo o café produzido no mundo e, às vésperas da queda do Império, já beirava os $60 \%$ da produção global. E como o produto seria produzido quase que exclusivamente para ser negociado nos mercados estrangeiros, esses mesmos anos ainda presenciariam o aumento da quantidade de sacas de café remetidas ao exterior. No decênio 1871-1880, foram enviadas mais de trinta milhões delas, e na década seguinte, a última do Império (1881-1890), essa marca ultrapassaria os cinquenta milhões. O embarque cada vez maior de sacas e mais sacas de café acabou por consolidar esta mercadoria como o principal produto da pauta das exportações brasileiras desde os anos 1830, posição em que permaneceria por mais seis décadas, até a sobrevinda da República $^{105}$.

À medida que a exportação do produto fosse se avolumando, a expansão das lavouras cafeeiras para outras áreas da província fluminense, ou em direção a Minas Gerais e às regiões paulistas do Vale do Paraíba e oeste da província, ia cada vez mais se tornando uma realidade na segunda metade do século XIX. A necessidade de se incrementar a produção fora ao mesmo tempo causa e efeito do alastramento das lavouras, sem dúvida, e, ao que parece, resultado direto da crescente procura dos mercados estrangeiros por esta mercadoria. Por outro lado, o constante crescimento dos índices de exportação do café foi transformando, de algum modo, a realidade em torno das atividades envolvidas desde a sua produção até o seu transporte aos mercados externos. Nesse sentido, as novas circunstâncias foram demandando a presença, e a disponibilidade no mercado, de novos serviços que porventura pudessem colaborar para a continuidade do café como principal produto na pauta das exportações brasileiras. A necessidade de serviços direta ou indiretamente relacionados a todo esse processo, enfim, tudo isso poderia ser traduzido em novas oportunidades de investimentos capitalistas no país.

Logo no início da década de 1850, a inexistência de uma infra-estrutura adequada a suportar esse movimento por que vinham passando as exportações brasileiras começou a despertar o interesse do capital estrangeiro para o investimento no território nacional. A

${ }^{105}$ Cf. NOYA PINTO, Virgílio, Balanço das transformações econômicas no século XIX, p. 139. 
construção de uma malha ferroviária, tão necessária à interligação das regiões recém desbravadas para o plantio de café com as cidades portuárias - como fora a interligação das lavouras do oeste paulista ao porto da cidade de Santos, no litoral sul da província de São Paulo -, muito embora tenha recebido grandes aportes de capital forâneo somente nos idos de 1876-1885, já em meados do século contara com alguma participação internacional. As ferrovias, ao que tudo indica, além de terem possibilitado o encontro das plantações com as terras férteis em áreas cada vez mais distantes, simultaneamente diminuíram essa distância até os portos diminuindo o tempo que as sacas de café levariam para chegar até os portos de partida aos mercados estrangeiros ${ }^{106}$.

O transporte marítimo, por sua vez, de igual modo chamou a atenção do capital disponível. Posto que as embarcações foram o principal meio utilizado para o transporte dos produtos exportados até seus portos de destino, a intensificação da navegação certamente contribuiria para o incremento de outros setores do comércio. A partir da década de 1860, então, juntamente com a vinda de investimentos infra-estruturais como o foram os direcionados para as ferrovias, inúmeras foram as companhias de navegação que iniciariam sua participação nessas transações comerciais transoceânicas. E, como não poderia deixar de ser, seguindo seus rastros, e talvez também porque interessadas na captação do capital posto em circulação com a abolição do tráfico negreiro, chegaram as companhias de seguros que, em sua maioria - pelo menos das que operaram seus negócios na província do Rio de Janeiro a partir de meados da década de 1840 -, eram britânicas.

Desde o início da década de 1840, a produção inglesa de bens de capital vinha perdendo cada vez mais espaço no mercado interno. Aproveitando a ótima fase que vivia a produção e o comércio mundial de meados do século, logo a Ilha se dedicou a exportar esses bens para além de suas fronteiras. Certamente haveria demanda para tudo isso, como fora o caso da exportação da construção ferroviária no Brasil, e em várias outras localidades do globo, principalmente durante a segunda metade do oitocentos ${ }^{107}$. Nos quinze anos compreendidos entre 1860 e 1875, as ferrovias, os bancos e as companhias de seguros foram responsáveis por $70 \%$ de todo capital estrangeiro investido no país, sendo que a parcela trazida pelas seguradoras, isoladamente, correspondeu a 11,8\%. Mas, muito acima de todas essas cifras estaria o montante que traduziria a preeminência britânica no século XIX: 94\% de todo o capital estrangeiro aportado no Brasil fora proveniente das firmas inglesas. No decênio posterior tal superioridade prevaleceria, mas levemente

${ }^{106}$ Cf. CASTRO, Ana Célia, As empresas estrangeiras no Brasil: 1860-1913, p. 03, 25.

${ }^{107}$ Cf. ARRIGHI, Giovanni, O longo século XX, p. 165,169,170. 
reduzida. Entre 1875 e 1885, portanto, a nacionalidade de $88 \%$ do capital estrangeiro investido no país era britânica, enquanto outros $10 \%$ foi de origem francesa, e o restante, $2 \%$, rateados entre as demais nações ${ }^{108}$.

Para a presença de companhias de seguros estrangeiras no Rio de Janeiro durante o período compreendido entre os anos de 1808 e 1889, encontramos resultados parecidos. Essas seguradoras começaram a operar seus negócios na praça comercial da província já na primeira metade do século, mas a maior parte delas foi se estabelecendo, sobretudo, nos quarenta anos seguintes. Os dez anos que completam a década 1871-1880 denunciariam pelo menos dois aspectos interessantes à compreensão do setor segurador. Em primeiro lugar, 19 companhias estrangeiras iniciaram suas negociações no mercado carioca, o que significou o maior número de instalações dessas companhias quando comparados aos números fornecidos pelas demais décadas. Em segundo lugar, os anos 1870 corresponderam ao decênio em que pela primeira vez o número de estabelecimentos de empresas estrangeiras foi ultrapassado pelo número de estabelecimentos de companhias nacionais, desde o início dos anos 1840. A seguir, a Tabela 2 mostra todas essas informações e também os números correspondentes às instalações de companhias nacionais e estrangeiras que foram conformando, década a década, esse mercado ao longo do Império.

\footnotetext{
${ }^{108}$ Cf. CASTRO, Ana Célia, op. cit., p. 23-24, 30, 35-36. A autora ainda informa sobre a parcela do capital aportado pelas companhias de seguros durante os anos posteriores a 1875 . Por uma tabela relativa ao período 1876-1885, percebemos que do total investido pelas companhias estrangeiras no Brasil apenas $0,7 \%$ correspondiam ao capital que fora trazido pelas seguradoras. No decênio seguinte, 1886-1896, elas seriam responsáveis por $30,7 \%$ do total investido, enquanto que as companhias de navegação trariam outros $26 \%$. De todo o capital proveniente das companhias de seguros estrangeiras durante este último período, $90 \%$ foi o correspondente à participação inglesa, o que reafirmara sua superioridade frente às demais nações. Para um período ainda maior, de cerca de quarenta anos entre 1860 e 1902, a média de todo o capital forâneo aportado em terras brasileiras pelas companhias de seguros estrangeiras girou em torno de 17,5\%; o restante, portanto, estaria vinculado às construções ferroviárias, aos bancos, às companhias de navegação, enfim, às empresas que ofereceriam outros serviços demandados pelo comércio, cf. ibidem, p.56-57, 63, 66, 87.
} 


\section{Tabela 2: Companhias de seguros nacionais e estrangeiras estabelecidas em cada década do período 1808-1889.}

\begin{tabular}{|c|r|r|r|r|}
\hline \multirow{2}{*}{$\begin{array}{c}\text { Período } \\
\text { década })\end{array}$} & \multicolumn{4}{|c|}{ Companhias de Seguros } \\
\cline { 2 - 5 } & Nacionais & \% sobre o total & \multicolumn{1}{|c|}{ Estrangeiras } & \% sobre o total \\
\hline $\mathbf{1 8 0 8 - 1 8 2 0}$ & 06 & $4,19 \%$ & 0 & $0 \%$ \\
\hline $\mathbf{1 8 2 1 - 1 8 3 0}$ & 04 & $2,80 \%$ & 0 & $0 \%$ \\
\hline $\mathbf{1 8 3 1 - 1 8 4 0}$ & 02 & $1,40 \%$ & 0 & $0 \%$ \\
\hline $\mathbf{1 8 4 1 - 1 8 5 0}$ & 05 & $3,50 \%$ & 07 & $4,90 \%$ \\
\hline $\mathbf{1 8 5 1 - 1 8 6 0}$ & 11 & $7,69 \%$ & 18 & $12,59 \%$ \\
\hline $\mathbf{1 8 6 1 - 1 8 7 0}$ & 07 & $4,90 \%$ & 14 & $9,79 \%$ \\
\hline $\mathbf{1 8 7 1 - 1 8 8 0}$ & 24 & $16,78 \%$ & 19 & $13,28 \%$ \\
\hline $\mathbf{1 8 8 1 - 1 8 8 9}$ & 12 & $8,39 \%$ & 14 & $9,79 \%$ \\
\hline Total & 71 & $49,65 \%$ & 72 & $50,35 \%$ \\
\hline
\end{tabular}

Fonte: Quadro Companhias de Seguros em funcionamento na Província do Rio de Janeiro (1808-1889), cf. Anexo 2.

Todas as 143 companhias de seguros existentes no Brasil, que apuramos para o período 1808-1889, estariam divididas quase que exatamente entre nacionais e estrangeiras. O início do século comportou, ao que tudo indica, uma concentração maior das seguradoras nacionais, enquanto que grande parte das companhias estrangeiras apareceriam na segunda metade do oitocentos. Pelo menos no que diz respeito ao estabelecimento de seguradoras internacionais, pudemos constatar que a partir de meados da década de 1840 a superioridade britânica frente às demais nações europeias, e também sobre os Estados Unidos, foi se consolidando à medida que os anos alcançavam o fim do Império. Na praça comercial da província do Rio de Janeiro foram se estabelecendo pouco mais de 70 companhias de seguros estrangeiras, e a nacionalidade de quase um terço delas seria identificada pela bandeira britânica. A alemã seria a nacionalidade de cerca de $20 \%$ das seguradoras estrangeiras que negociaram suas apólices no mercado carioca, seguidas pelas companhias estadunidenses, que correspondiam a cerca de $8 \%$ das estrangeiras instaladas na província, tudo conforme pode ser apreendido dos dados que vão no Gráfíco 3 , a seguir. 


\section{Gráfico 3: Nacionalidades das Companhias de Seguros estrangeiras estabelecidas na Província do Rio de Janeiro (1808-1889)}

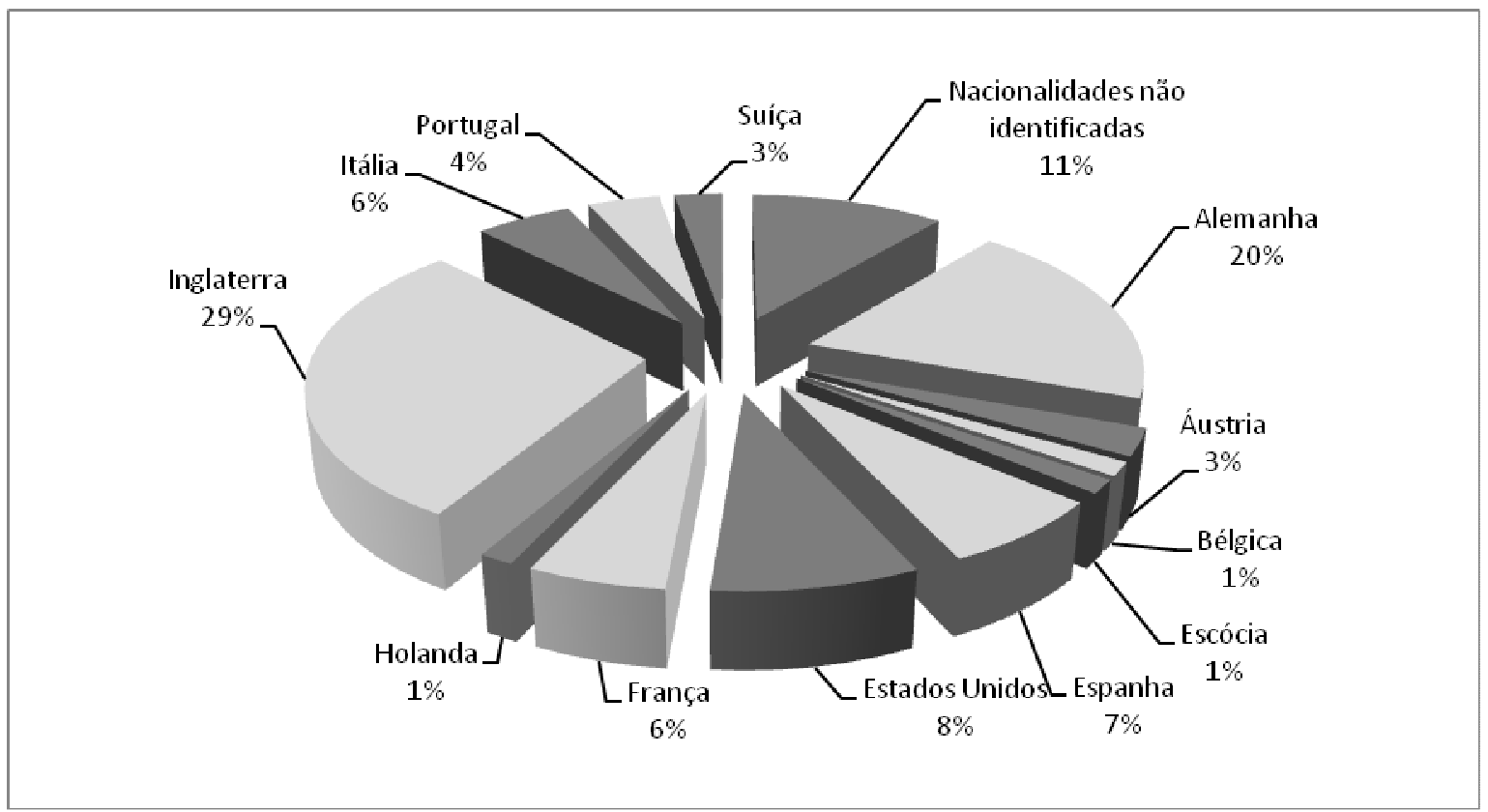

Fonte: Quadro Companhias de Seguros em funcionamento na Província do Rio de Janeiro (1808-1889), cf. Anexo 2.

As companhias inglesas foram se estabelecendo principalmente depois de meados da década de 1860, enquanto que nenhuma seguradora alemã, segunda maior nacionalidade presente na praça comercial do Rio de Janeiro, foi instalada nos doze anos que fizeram o período 1860-1872. As quatro seguradoras francesas, que assim como as italianas constituíam a quinta maior bandeira dentre as companhias de seguros estrangeiras que negociaram na província, surgiram todas elas entre 1846 e 1861. O Gráfico 4 revela, ano a ano, as principais nacionalidades das companhias seguradoras que foram aparecendo no mercado carioca a partir de 1843. Além das que já foram mencionadas, ele ainda informa algo sobre a trajetória dos investimentos estadunidenses e espanhois nesse ramo do mercado. 
Gráfico 4: Nacionalidades das principais Companhias de Seguros estrangeiras estabelecidas na Província do Rio de Janeiro (1843-1889)

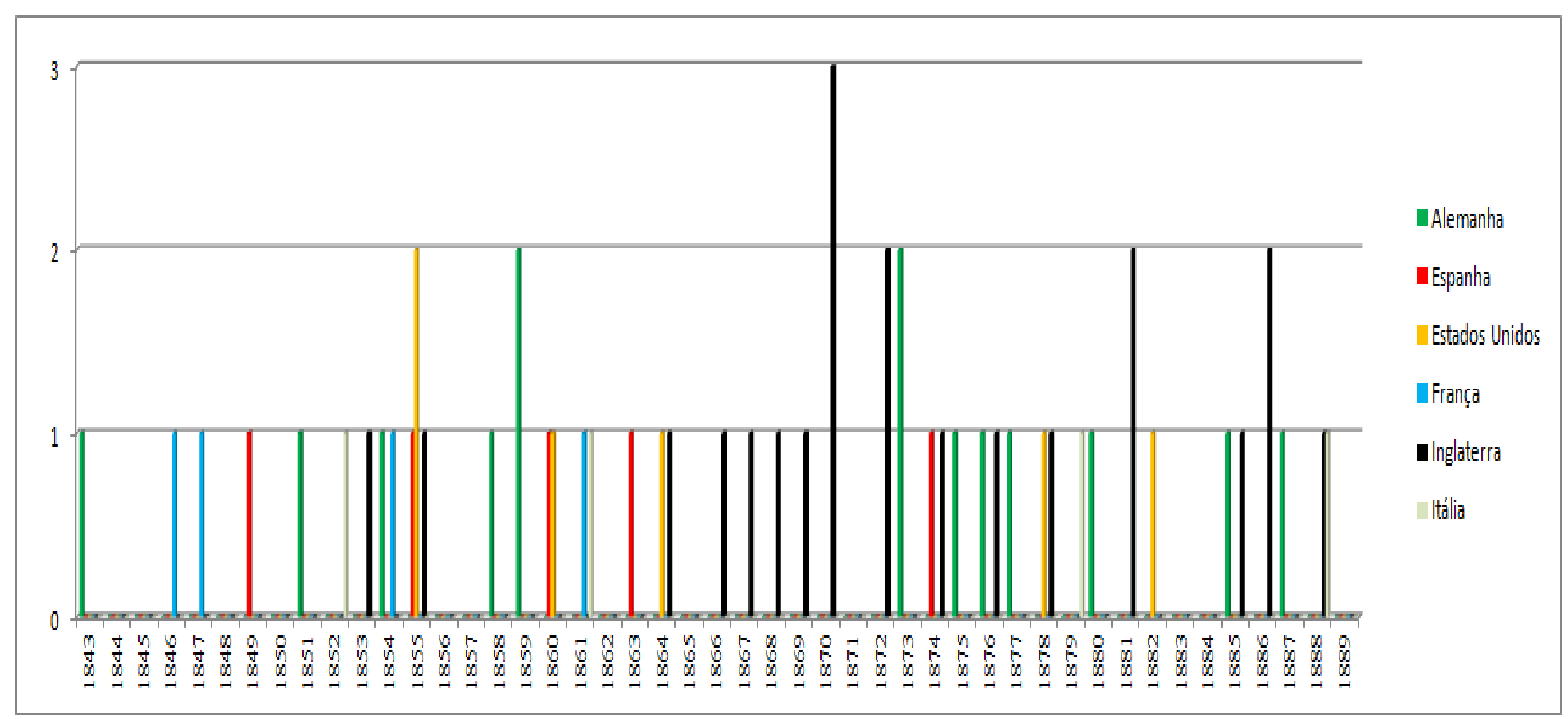

Fonte: Quadro Companhias de Seguros em funcionamento na Província do Rio de Janeiro (1808-1889), cf. Anexo 2. 
Nesse mercado, uma variedade enorme de riscos pode ser contratada pelas companhias que operaram seus negócios no Rio de Janeiro. Os empreendimentos marítimos, por exemplo, estariam garantidos contra os danos ou a destruição que bem poderiam afetar os navios ou as cargas transportadas, e por conseguinte diminuiriam a rentabilidade dos negócios. De todas as 143 seguradoras que atuaram na praça comercial carioca, 36 se dedicaram exclusivamente a negociar sobre os riscos classificados no ramo dos seguros marítimos. Outras 28 companhias, além dos riscos previstos para a navegação de mares e rios, contratariam também os que atingiam a vida ou as atividades comerciais quando realizadas em terra. A vida mesma, de pessoas livres ou escravas; os incêndios que bem poderiam derrubar as propriedades, ou danificar prédios e objetos; o "azar" de ser sorteado para compor as fileiras do Exército; o transporte de mercadorias, por terra; todos eles acompanhariam outros riscos, todos eles classificados no ramo dos seguros terrestres.

Todas essas eventualidades que poderiam acometer a vida ou as transações terrestres foram garantidas por um número maior de companhias de seguros. De todas as seguradoras que chegaram a atuar no mercado carioca, 37,06\% contratariam exclusivamente sobre os riscos terrestres. O Gráfico 5 e o Gráfico 6 mostram a atuação dessas companhias. O primeiro divide todas elas com base em três critérios: seguradoras exclusivas de riscos marítimos; as que contrataram exclusivamente os seguros terrestres; e as que chagaram a garantir riscos classificados nos dois ramos, não necessariamente ao mesmo tempo, mas em algum momento de suas existências. O Gráfico 6, por sua vez, apresenta os mesmos resultados, porém atribui às companhias nacionais e estrangeiras suas responsabilidades pela conformação desse mercado segurador. 


\section{Gráfico 5: Riscos segurados pelas Companhias de Seguros estabelecidas}

na Província do Rio de Janeiro (1808-1889)

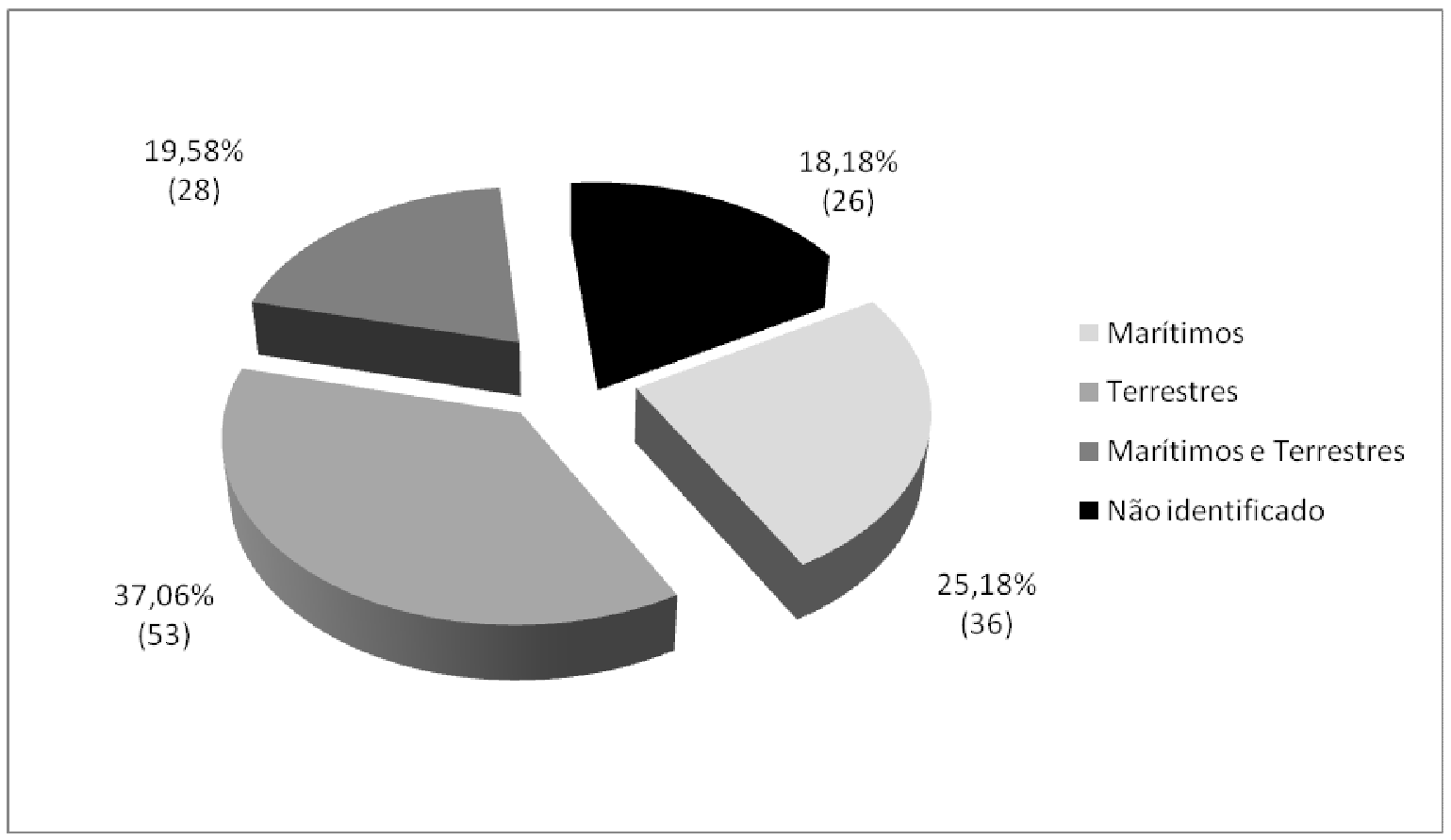

Fonte: Quadro Companhias de Seguros em funcionamento na Província do Rio de Janeiro (1808-1889), cf. Anexo 2.

Gráfico 6: Riscos segurados pelas Companhias de Seguros nacionais e estrangeiras estabelecidas na Província do Rio de Janeiro (1808-1889)

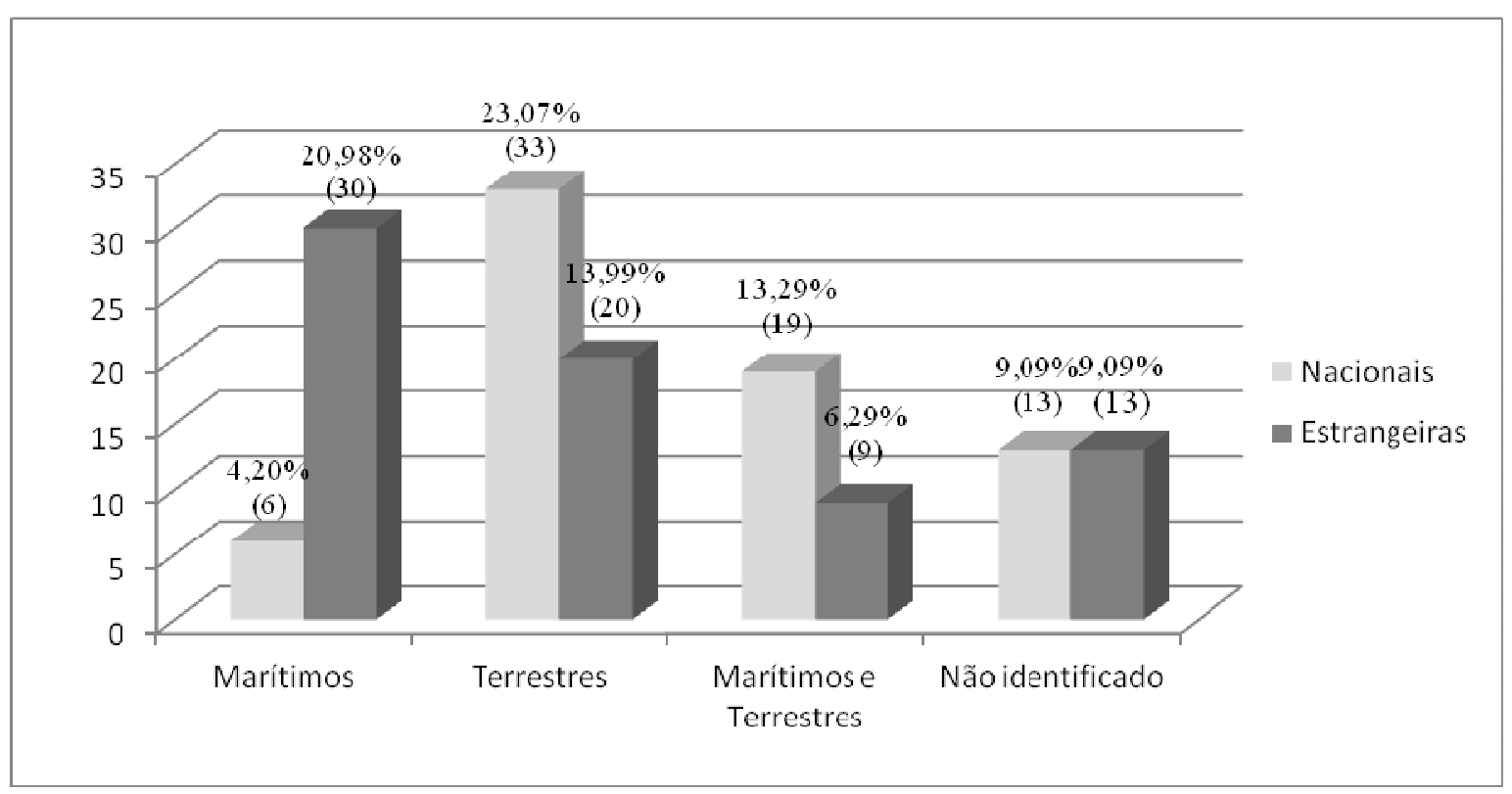

Fonte: Quadro Companhias de Seguros em funcionamento na Província do Rio de Janeiro (1808-1889), cf. Anexo 2. 
Dentre as companhias de seguros que se dedicaram exclusivamente sobre a contratação de riscos inerentes à navegação marítima ou fluvial, as companhias estrangeiras foram muito mais numerosas que as nacionais. Durante quase todo o oitocentos, mais de $80 \%$ das seguradoras que se especializaram neste negócio estariam sediadas na Europa ou nos Estados Unidos. Se o que se passou com o setor segurador refletiu a realidade dos investimentos empregados em outras atividades comerciais, estes dados podem se configurar em algum indicativo da superioridade das potências europeias, ou da norte americana, no jogo capitalista vigente durante o século XIX. Além de garantir grandes perdas, como os casos das embarcações ou das mercadorias transportadas, e talvez por isso exigir a disponibilidade de grandes somas de capital; ao ramo dos seguros marítimos não só desaguariam grandes valores captados do meio circulante, como os lucros provenientes dos prêmios pagos ainda poderiam ser incrementados mediante o investimento em outras atividades mercantis, como o depósito a juros nos bancos, ou a compra de ações de companhias ou de títulos do governo.

Por outro lado, dentre aquelas que garantiram exclusivamente as perdas provenientes dos sinistros ocorridos em terra, pouco mais de $60 \%$ seriam empresas nacionais, quase a mesma proporção encontrada para as companhias que estiveram autorizadas a segurar os riscos provenientes dos empreendimentos marítimos (e fluviais) e terrestres. Contudo, as companhias, fossem elas nacionais ou estrangeiras, estivessem elas atuando nos ramos marítimos, terrestres, ou simultaneamente em ambos; começariam a se estabelecer sobretudo na segunda metade do século, e compartilhariam, ao que parece, as mesmas oportunidades oferecidas pelo mercado.

O Gráfico 7 e o Gráfico 8 acabam por revelar essa tendência. Ano a ano informam não só o número de companhias estabelecidas na província do Rio de Janeiro, como os ramos de seguros sobre os quais estariam dedicadas a contratar: se em um só, ou se em dois. 
Gráfico 7: Riscos segurados pelas Companhias nacionais que foram se estabelecendo, ano a ano, na Província do Rio de Janeiro (1808-1889)

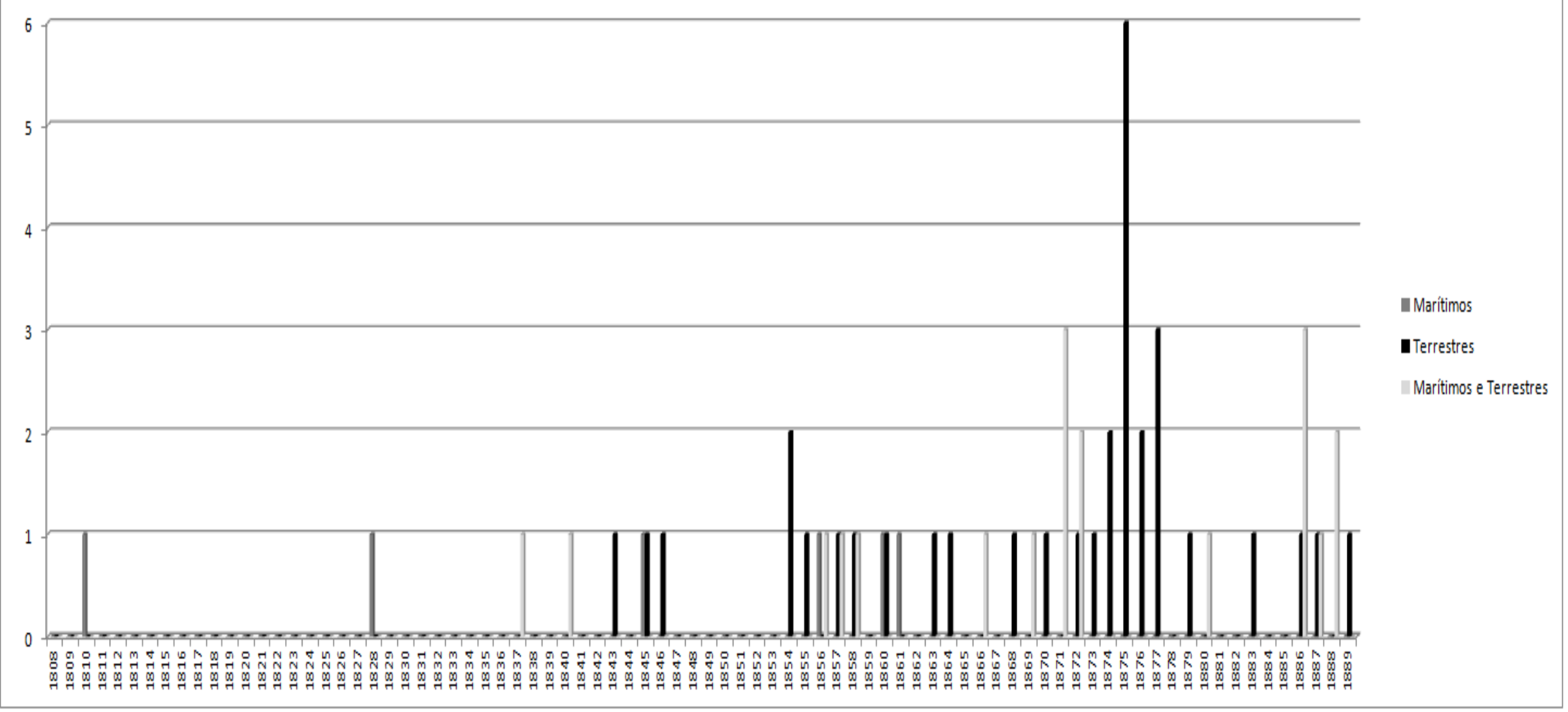

Fonte: Quadro Companhias de Seguros em funcionamento na Província do Rio de Janeiro (1808-1889), cf. Anexo 2. 
Gráfico 8: Riscos segurados pelas Companhias estrangeiras que foram se estabelecendo, ano a ano, na Província do Rio de Janeiro (1843-1889)

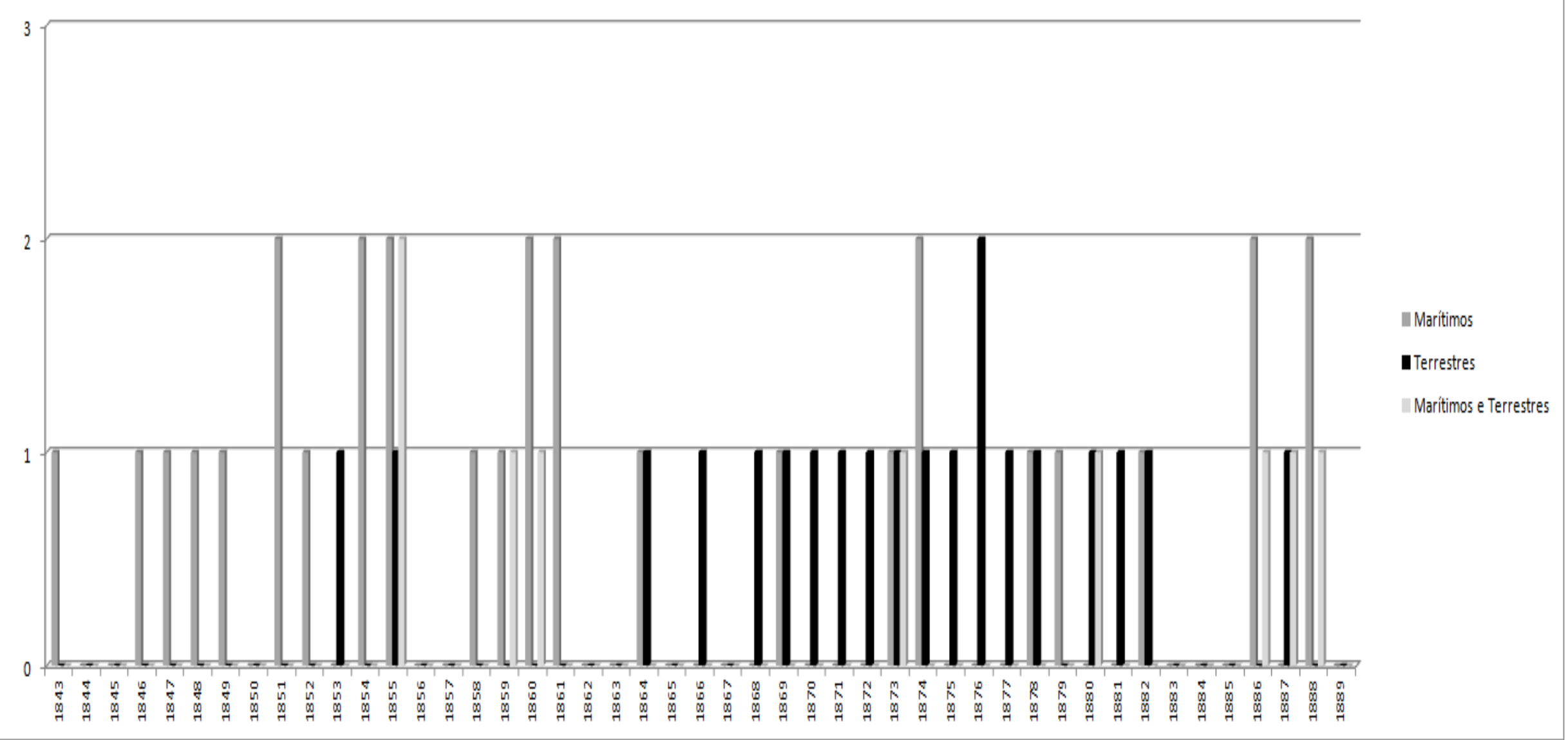

Fonte: Quadro Companhias de Seguros em funcionamento na Província do Rio de Janeiro (1808-1889), cf. Anexo 2. 
Esses gráficos buscam enfatizar as operações das companhias de seguros por meio da identificação dos ramos sobre os quais estiveram autorizadas a contratar. Por essa razão eles informam apenas a quantidade e a porcentagem de seguradoras que estariam aptas a contratar os riscos marítimos ou terrestres, isoladamente, ou ambos, simultaneamente. Contudo, eles apenas noticiam as características referentes às atuações dessas companhias que foram se estabelecendo no mercado carioca ao longo do século XIX, e deixam de informar expressamente sobre outras características da formação desse mercado. Outros dados tão interessantes à compreensão do papel jogado pelos seguros na província do Rio de Janeiro, portanto, poderiam ser fornecidos se enfatizássemos os riscos segurados, ao invés das companhias de seguros.

Nesse sentido, o desmembramento das companhias que garantiram simultaneamente os riscos classificados nos dois ramos de seguros, para depois serem computadas tanto no bloco das que contrataram exclusivamente os riscos marítimos, como no grupo que somente atuou no ramo terrestre; renderia a informação de que de todas as 143 companhias de seguros estabelecidas na província do Rio de Janeiro durante o período pesquisado (1808-1889), 81, ou o correspondente a 56,64\% do total, dedicaram-se à contratação dos riscos inerentes à realização dos empreendimentos terrestres, seja exclusiva ou simultaneamente à negociação de riscos marítimos. Desse montante, 52 seriam companhias nacionais (o que equivaleria a 36,36\% do total de seguradoras, ou a $64,2 \%$ dentre as que chegaram a atuar no ramo terrestre); e outras 29 seriam estrangeiras (20,27\% do total, ou 35,8\% de todas as companhias que garantiram os riscos terrestres). Os riscos inerentes aos empreendimentos marítimos ou fluviais, por sua vez, foram segurados por 64 das 143 companhias de seguros estabelecidas na praça comercial do Rio de Janeiro durante o século XIX. Isso corresponderia, em termos percentuais, a 44,75\% de todas as seguradoras que chegaram a atuar naquele mercado. As companhias nacionais, em número de 25 (ou o equivalente a 17,48\% sobre o total de companhias, ou 39,06\% sobre aquelas que somente chegaram a garantir os riscos marítimos), perderiam terreno para as companhias estrangeiras sobretudo na segunda metade do século. Estas últimas contavam 39 , e perfaziam $27,27 \%$ de todas as seguradoras ali estabelecidas (ou $60,94 \%$ somente das que contratavam os riscos marítimos).

Todas as tabelas e gráficos apresentados anteriormente acabam por desenhar um mapeamento físico, digamos, do mercado segurador estabelecido na praça comercial do 
Rio de Janeiro. Expõem números gerais e particulares que paulatinamente foram caracterizando esse ramo mercantil negociado na província, durante os anos compreendidos entre 1808 e 1889.

De um modo geral, eles informam sobre a quantidade de companhias de seguros que tiveram suas respectivas incorporações autorizadas pelo poder imperial - ou que ali foram autorizadas a operar por meio de seus agentes, como foram os casos das companhias estrangeiras -, ou mesmo que chegaram a funcionar sem o reconhecimento oficial; informam, de igual modo, sobre a quantidade de companhias, nacionais e estrangeiras, que ali anualmente foram se estabelecendo, números que somente puderam ser conhecidos a partir das primeiras notícias que as fontes pesquisadas para o período forneceram acerca da existência de cada uma das seguradoras; revelam, por fim, a disposição das companhias em garantir os riscos classificados em cada um dos ramos do seguro, isoladamente, ou em ambos, conjuntamente. São todos dados, como se vê, que caracterizam o perfil das companhias de seguros que estiveram presentes no Rio de Janeiro durante o século XIX, se nacionais ou estrangeiras, se seguradoras destes ou daqueles riscos.

Contudo, traçar o perfil desse mercado segurador, em si, exigiria a soma de outras informações, que escaparam à elaboração dos quadros anteriores. Se a eles fossem acrescentadas, por exemplo, as informações referentes às datas em que as companhias seguradoras deixaram de operar na província do Rio de Janeiro - informações que corresponderiam às últimas notícias a respeito das existências dessas empresas, e que de igual modo puderam ser conhecidas pelas fontes consultadas para todo o período 18081889 -, talvez servissem à elaboração de novos gráficos que porventura dessem conta de descobrir as épocas em que o mercado foi se reformulando com a maior ou menor movimentação de companhias, independente de suas nacionalidades ou dos ramos sobre os quais realizavam seus contratos.

Nesse sentido, o Quadro Companhias de Seguros em funcionamento na Província do Rio de Janeiro (1808-1889) ${ }^{109}$ traz consigo uma coluna em que vão relacionadas as 'datas finais', ou seja, as datas condizentes às últimas notícias acerca do funcionamento, e da existência, de cada uma das 143 seguradoras que chegaram a atuar na praça comercial carioca. Informa, portanto, a vigência dessas companhias, porém o faz de maneira individual. Isto quer dizer que suas linhas denunciam sem maiores problemas a permanência de cada empresa nesse mercado; mas que, por outro lado, um panorama

\footnotetext{
${ }^{109}$ Cf. Anexo 2, p. 195.
} 
comparativo de todos esses períodos ainda demandaria uma nova reorganização dos dados apresentados pelo Quadro.

Esse panorama comparativo é o que tentam mostrar o Gráfico 9 e o Gráfico 10. Eles cruzam as informações referentes ao período de funcionamento de cada uma das companhias de seguros conhecidas pela praça comercial do Rio de Janeiro durante o século XIX, para a partir daí revelarem a quantidade de seguradoras que estariam oferecendo seus serviços, ano a ano, a quem se dispusesse a contratá-los. Por eles percebemos que, assim como já haviam revelado os gráficos anteriores, fora sobretudo a partir do início da década de 1840 que o mercado segurador da província começa a se intensificar. Durante os anos compreendidos entre 1851-1860, a média do número de seguradoras que estiveram em funcionamento na província quase triplicara em relação à conhecida pelo decênio anterior. A década seguinte (1871-1880) acabou se configurando em outro período de intensa atividade seguradora nesse mercado carioca. Cerca de 40 companhias estiveram em funcionamento durante cada um dos anos de 1870, 10 a mais, portanto, que a média alcançada pelos dez anos anteriores (1861-1870). A média apurada para a década de 1870 acabou se perpetuando para os anos que se seguiriam a ela. De todos os anos que compuseram o período averiguado (1808-1889), o ano de 1888 foi o que serviu de palco à atuação do maior número de companhias de seguros: as fontes permitiram que fossem levantadas 50, que muito provavelmente sobreviveriam ao fim do Império.

Dessas 50 companhias, 23 seriam nacionais e 27 estrangeiras. O Gráfico 10 evidencia a parcela com que cada uma delas contribuiu para a conformação do setor de seguros daquela praça comercial. Nota-se que a partir de meados do século o número de seguradoras estrangeiras em funcionamento no mercado carioca, pela primeira vez, ultrapassou o de companhias nacionais. A partir da década de 1850 (1851-1860), portanto, a média do número de companhias estrangeiras que estiveram em funcionamento na província do Rio de Janeiro foi sempre maior que a média apurada para as seguradoras nacionais ao longo de todo o período (1851-1888). Com exceção dos anos de 1871, e 1875-1876, todos os outros revelaram a preeminência estrangeira no lucrativo negócio dos seguros. Por outro lado, a trajetória individual das companhias brasileiras revela a mais intensa atividade dessas empresas nos últimos vinte anos do Império. De fato, a média de seguradoras nacionais em funcionamento no mercado carioca conheceu um grande salto na passagem da década de 1860 (1861-1870) para a de 1870 (1871-1880), e que acabou se estabilizando até o fim do decênio seguinte. $O$ ano de 1876, que fizera parte desse 
recrudescimento, fora o ano que presenciou o maior número de seguradoras dispostas a contratar. Foram 25, quase a mesma quantidade de companhias estrangeiras (27) que funcionaram em 1888, ano de seu maior pico. A década de 1880 (1881-1888), por sinal, acabou sendo aquela que forneceu a maior média de seguradoras estrangeiras em funcionamento no mercado do Rio de Janeiro. Dentre todas as nacionalidades que ali chegaram a realizar seus negócios, excetuando-se a brasileira, a superioridade das companhias alemãs pode ser percebida sobretudo durante os anos 1840-1860; a partir daí quem tomou a dianteira da concorrência foram as seguradoras inglesas, e aí se manteriam até os anos finais do período (1860-1888).

Para além da presença de companhias seguradoras nacionais e estrangeiras, esse mercado também foi caracterizado pela maior ou menor concentração de negociações sobre cada um dos riscos classificados nos dois ramos de seguros. O Gráfico 11 reorganiza os dados do Quadro Companhias de Seguros em funcionamento na Província do Rio de Janeiro (1808-1889) para esclarecer as épocas em que as seguradoras, de um modo geral, mais se dedicaram a garantir os riscos inerentes aos empreendimentos marítimos e terrestres. Por ele pode ser percebido que, a partir de meados da década de 1840, um número cada vez maior de seguradoras estariam dispostas a indenizar os segurados pelos sinistros que lhes acometessem as embarcações, as mercadorias, e demais gêneros postos ao mar. A partir daí esse crescimento seria contínuo até o ano de 1861, quando 28 companhias estiveram segurando os riscos marítimos. Esse número diminuiria no decorrer dos anos seguintes, e viria a ganhar novo fôlego já no final da década de 1860 até pelo menos o começo dos anos de 1870, quando permaneceria estável por um breve período, antes de tornar a sofrer as variações daquele mercado.

O número de companhias que garantiam os riscos terrestres conheceu um crescimento vertiginoso, e praticamente contínuo, principalmente a partir de meados do século. A exceção estaria situada nas leves quedas sofridas durante alguns anos da década de 1860, e durante o decênio 1875-1885. O ano de 1888, último ano do período analisado pelo Gráfico 11, portanto, foi o que pode presenciar o maior número de companhias em atividade: 38 seguradoras, das 50 que estiveram em funcionamento, se disponibilizaram a realizar seus contratos sobre a garantia dos riscos terrestres. 
Gráfico 9: Companhias de Seguros em funcionamento da Província do Rio de Janeiro (1808-1888)

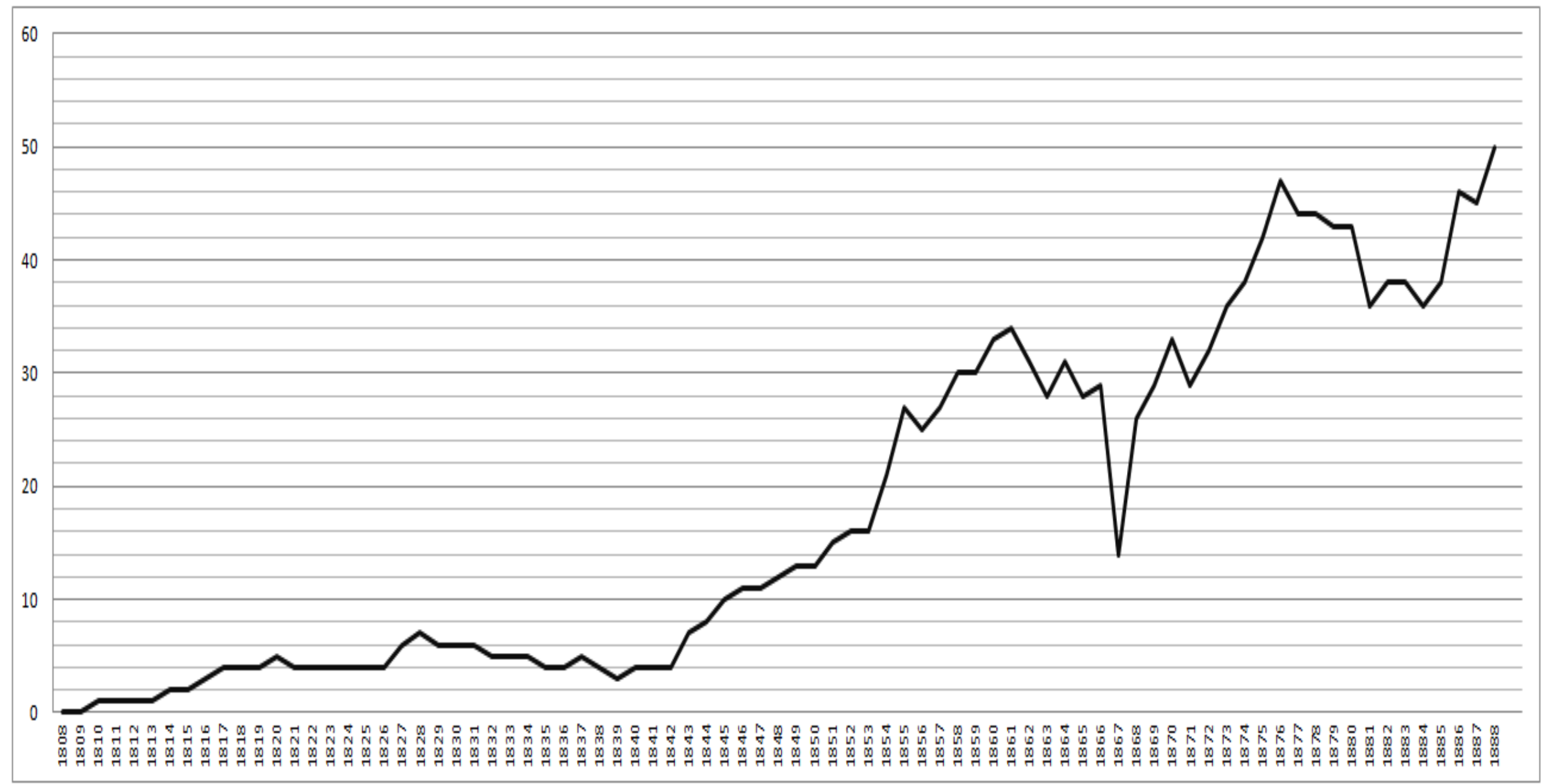

Fonte: Quadro Companhias de Seguros em funcionamento na Província do Rio de Janeiro (1808-1889), cf. Anexo 2. 
Gráfico 10: Companhias de Seguros nacionais e estrangeiras em funcionamento na Província do Rio de Janeiro (1808-1888)

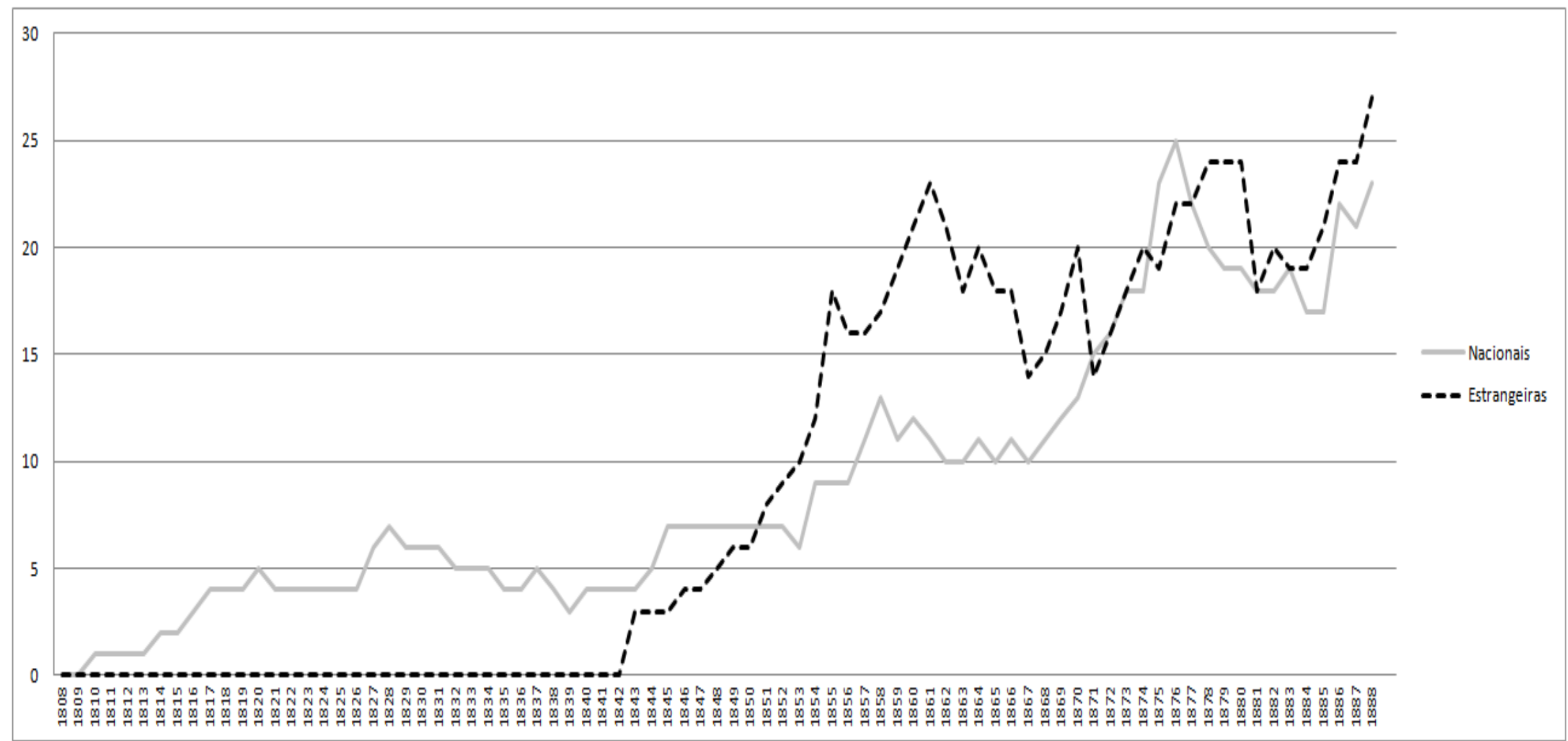

Fonte: Quadro Companhias de Seguros em funcionamento na Província do Rio de Janeiro (1808-1889), cf. Anexo 2. 
Gráfico 11: Companhias seguradoras de riscos marítimos e terrestres em funcionamento na Província do Rio de Janeiro (1808-1888)

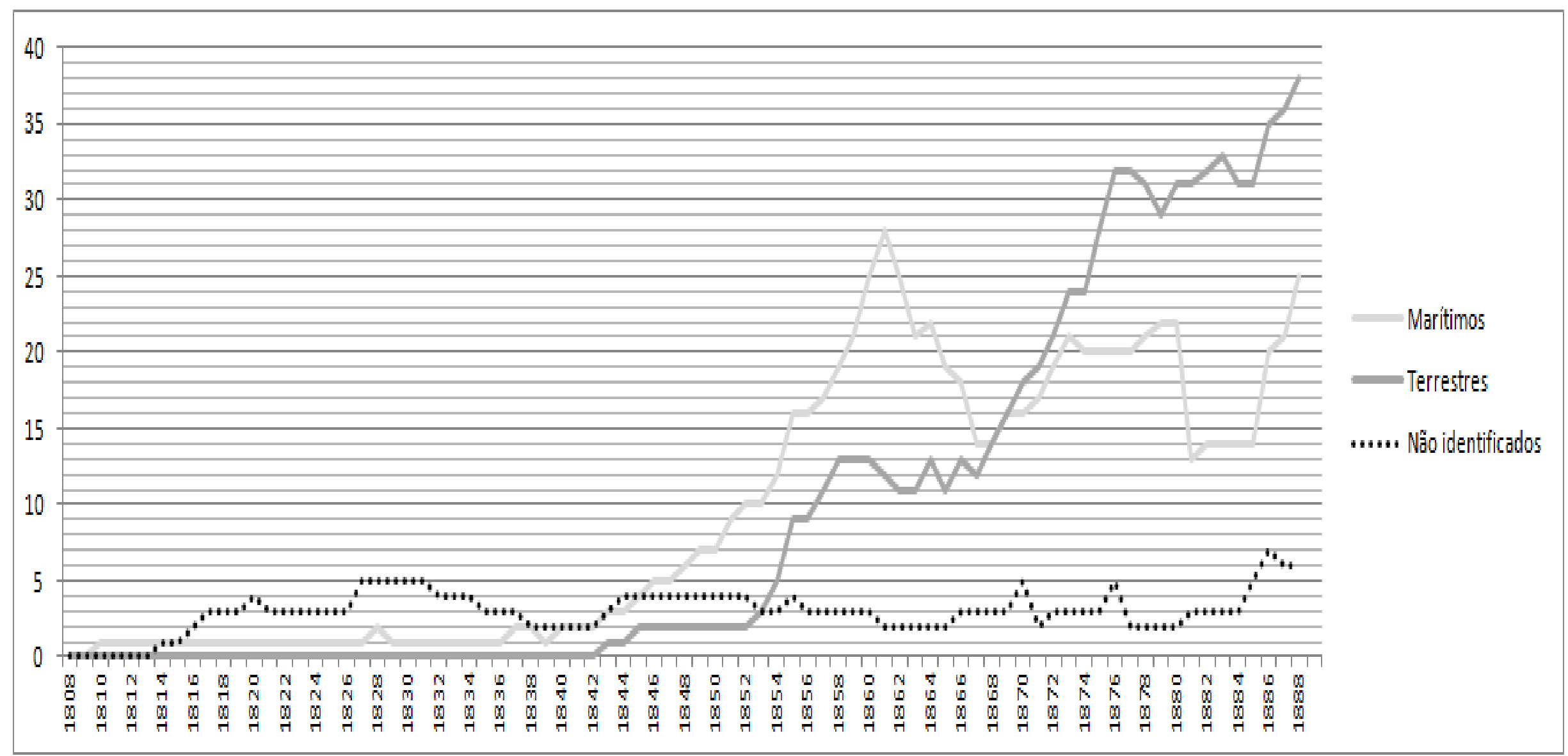

Fonte: Quadro Companhias de Seguros em funcionamento na Província do Rio de Janeiro (1808-1889), cf. Anexo 2. 


\section{O Tratamento dispensado aos seguros pela doutrina jurídica de ponta a ponta do oitocentos.}

O século XIX, ao que parece, foi costurado por certa permanência no modo como os juristas entenderiam os seguros, pelo menos sob um aspecto específico. É bem verdade que algumas questões seriam constantemente debatidas, cada resposta aos problemas construída sobre interpretações distintas que se tiravam das leis que regulavam o instituto. Muitas dessas discussões puderam ser presenciadas, por exemplo, por advogados, magistrados, e outros operadores do direito, quando se buscou julgar a necessidade de se provar o valor do objeto segurado danificado, ou destruído, pela sobrevinda do sinistro; ou quando se pôs em dúvida a competência do juízo comercial para o julgamento das causas geradas a partir de determinados contratos de seguros; ou mesmo, já nem tão ao alcance dos tribunais, quando foi discutida a legalidade ou ilegalidade da contratação sobre alguns riscos em especial. Mas, apesar de tudo isso, de ponta a ponta do oitocentos a doutrina jurídica que se fizera em torno do direito comercial continuaria a classificar este contrato em apenas dois ramos, a depender, cada um, do lugar da proveniência dos riscos que poderiam acometer os empreendimentos capitalistas.

Momentos antes da entrada do século, o tema dos seguros já havia sido de interesse dos juristas. José da Silva Lisboa, o Visconde de Cairu, publicara o primeiro tratado dos Princípios de Direito Mercantil e Leis de Marinha já em 1798. O que o motivara vir a lume foi a "falta de conhecimento em matéria tão importante, e quotidianamente frequentada nas praças", e que apesar disso o que se via era a celebração de "muitos contratos de Seguro sem as cautelas necessárias, ou com artifícios ilegítimos: de que resultam inumeráveis prejuízos, e litígios, que tanto arruínam os Negociantes (...)". Por isso, este volume fora elaborado a servir, pelo que diz no prólogo da obra, "à generosa mocidade Portuguesa, que cultiva o Comércio (...); não se precipitando, por inexperiência, a fazer convenções mercantis, ou inúteis, ou ruinosas (...)"110.

O conjunto da obra ainda seria composto por outros sete tratados. O segundo deles seria reservado ao tratamento da matéria Do Câmbio Marítimo; o terceiro, Das Avarias; o quarto tratado seria destinado aos estudos Da Letra de Câmbio; o seguinte expunha o tema Dos Contratos Mercantis; o sexto trataria Da Polícia dos Portos e Alfândegas; o tratado de número sete trouxe publicada matéria relativa à jurisdição mercantil, e foi denominado Dos

\footnotetext{
${ }^{110}$ Para as citações deste parágrafo, cf, LISBOA, José da Silva, Visconde de Cairu, Princípios de Direito Mercantil e Leis de Marinha, p. 8, 9.
} 
Tribunais e Causas de Comércio; a oitava parte, por fim, seriam os Princípios de Economia Política. Todos eles, enfim, fariam os Princípios de Direito Mercantil e Leis de Marinha que, segundo as palavras de Cândido Mendes de Almeida ${ }^{111}$, tratou-se de obra "única no gênero, em língua vernácula, [e] serviu na época de Código Comercial, de indisputável autoridade em todos os domínios da Monarquia Portuguesa"112.

Afora a importância que os coevos enxergaram nesta obra de tamanho porte, o primeiro tratado, denominado Dos Seguros Marítimos, foi dividido em três partes - da formação do contrato de seguro; da dissolução do contrato de seguro; e da execução do contrato de seguro - e traria expressamente a definição do autor acerca da divisão que costumeiramente se fazia sobre as contratações de riscos. De fato, logo na primeira parte, em seu primeiro capítulo - Da divisão genérica do Contrato de Seguro - Silva Lisboa, amparado pela sua concepção do negócio, expõe seu entendimento acerca da classificação doutrinária dos seguros:

\begin{abstract}
Compreendendo-se aqui os usos, e costumes de todas as Nações Comerciantes, pode-se considerar como matéria do Contrato do Seguro toda a propriedade, que tem perigo de deteriorar-se, ou perder-se, assim no transporte de um lugar para o outro, como na conservação dela em lugar determinado, e permanente. Daqui nasce a divisão genérica de Seguro marítimo e Seguro terrestre; pois se podem segurar não só os efeitos, e quaisquer bens circulantes, que se transportam por mar, ou rios navegáveis, senão também os que traspassam por terra para algum lugar destinado, e ainda os que se acham guardados, ou fixos nas casas, e fundos
\end{abstract}

111 Cândido Mendes de Almeida nasceu em 14 de outubro de 1818, no Maranhão. Chegou a exercer a advocacia. Foi professor, jornalista, magistrado e promotor público. Elegeu-se Deputado pela primeira vez em 1843, e quando faleceu, em $1^{\circ}$ de março de 1881, ocupara um assento na câmara do Senado havia pelo menos uma década. Publicou, dentre outras obras, os Arestos do Supremo Tribunal de Justiça (Rio de Janeiro: 1880, 2 vols.).

112 Cf. ALMEIDA, Cândido Mendes, Ao Leitor, p. vii. O primeiro tratado dos Princípios de Direito Mercantil e Leis de Marinha foi publicado no ano de 1798, e depois em 1801. Cândido Mendes de Almeida justifica porque atribuiu a sexta edição aos dois volumes da obra publicados em 1874, e anotados por ele. E ao fazê-lo, traça um histórico das publicações que ganhou os Princípios: "Parece que toda esta obra, ou alguns dos seus Tratados, tiveram diferentes edições em 1815, 1817, 1819 e 1829, de que aliás os Editores não dão notícia em algum Prólogo, embora nenhuma alteração se fizesse nos mesmos trabalhos", cf. ibidem, p. xv-xvi. Coincidência ou não, pelas datas das publicações dessas edições percebemos que elas vieram a lume no correr dos primeiros trinta anos do século XIX: época em que o comércio marítimo foi incrementado pela nova realidade trazida com a instalação da Corte no Rio de Janeiro; mas que também foi caracterizada por certa confusão quanto à legislação a ser aplicada nas decisões das contendas levadas pelos comerciantes aos Tribunais, em boa parte provocadas pela inexistência da uniformização das leis mercantis, o que só veio a ocorrer no Brasil em meados do século XIX, com a promulgação do Código Comercial em 1850. A sexta edição publicada em 1874, contudo, não saiu completa, pelo menos não nos moldes da obra original. Cândido Mendes de Almeida afirma que "preterimos reproduzir a oitava parte que trata dos Princípios de Economia Política, por ter fraca relação com a matéria sujeita; além de que já se achava por esta circunstância fora de todas as compilações que tivemos presentes (...)". E continua: "Para preencher, e com vantagem, esta falta adicionamos dois opúsculos do autor - as Regras da Praça, ou bases do Regulamento Comercial, conforme nos novos Códigos de Comércio, e a Legislação Pátria, e as Reflexões sobre o Comércio dos Seguros, que tem corrido fora desta compilação, e que, aliás, tem com ela estreita relação.”, cf. ibidem, p. xii. 
territoriais, que são sujeitos aos perigos do fogo, invasão de inimigos, e outros infortúnios extraordinários. ${ }^{113}$

Como se vê, a "divisão genérica do Contrato de Seguro" estaria estritamente subordinada ao local onde o empreendimento seria realizado. Se em mar, ou se em terra, cada um dos ambientes proporcionaria riscos específicos aos negócios capitalistas. Esse critério para a classificação dos seguros, ao que parece, atravessaria o Império, e far-se-ia presente na doutrina jurídica produzida nos idos de sua última década.

Em 1883, a Casa H. Laemmert \& Cia. anunciava nas páginas do almanaque que levava seu sobrenome, que acabara de publicar uma obra sobre seguros marítimos e terrestres “escrita pelo distinto advogado Dr. José da Silva Costa ${ }^{114}$ ”. O anúncio, feito em nota de roda-pé logo na primeira página da seção Seguro, ainda persistiria nos números publicados entre 1884 e 1889. Contudo, seria somente no ano de 1886 que os editores do Almanak Laemmert divulgariam a chegada deste livro em tom mais alto do que de costume, e o fizeram por meio de um texto de propaganda mais extenso que os anteriores, o qual, além de tentar convencer de sua importância para o cotidiano das profissões mercantis, ressaltava a figura do autor, ao mesmo tempo em que destrinchava as partes da obra para o conhecimento do público:

\begin{abstract}
Sobre todas as questões de Seguros marítimo e terrestre o ilustrado Sr. Dr. José da Silva Costa, doutor em ciências jurídicas e sociais e membro do Instituto dos Advogados Brasileiros, luzeiro mui vantajosamente conhecido neste Império, no foro e na literatura jurídica, compilou e publicou o seguinte tratado: Seguros Marítimos e Terrestres, em três partes e 18 capítulos a obra trata substancialmente de todas as espécies de seguro marítimo e terrestre como sejam:

Natureza do contrato de seguro, objeto de seguro marítimo, seguro vedado, avaliação do objeto seguro, riscos, duração dos riscos, abandono, prêmio, indenização, apólices e suas enunciações, interpretação da apólice, dissolução do contrato de seguro, competência e jurisdição, ações e exceções. No intuito de facilitar o exame vão em apêndice expressas as condições das apólices de várias companhias de seguro, ocampanhando (sic) ainda um índice muito especializado e alfabético de todas as matérias tratadas na obra. ${ }^{115}$
\end{abstract}

\footnotetext{
${ }^{113}$ LISBOA, José da Silva, Visconde de Cairu, op. cit., p. 13.

114 José da Silva Costa é natural do Rio de Janeiro, e nasceu no dia 2 de abril de 1841 . Bacharelou-se em Direito pela Faculdade de São Paulo e foi nomeado Juiz Municipal. Porém, foi na advocacia que acabou dedicando grande parte de sua carreira jurídica. Foi sócio do Instituto dos Advogados Brasileiros (IAB), e chegou a exercer a docência na Faculdade Livre de Ciências Jurídicas e Sociais, fundada em 1892, na capital da República. Dirigiu e redigiu a Revista Jurídica: doutrina, legislação, jurisprudência e bibliographia (1862-1873) e, além dos Seguros marítimos e terrestres (1883), publicou Sociedades anonymas (1882); Contrato de conta corrente (1886), dentre outras obras.

115 Cf. Almanak administrativo, mercantil e industrial do Rio de Janeiro - Almanak Laemmert, 1886, p. 1.645. Os anúncios inseridos nos números do Almanak publicados durante os anos 1883-1889 o foram nas seguintes páginas: 1883 , p. $1.295 ; 1884$, p. $1.311 ; 1885$, p. $1.297 ; 1887$, p. $1.627 ; 1888$, p. $1.643 ; 1889$, p. 1.641. A publicação de 1886 contou, na verdade, com dois anúncios: o maior, citado no corpo do texto; e um igual ao que constou dos números citados anteriormente. Este último foi inserido na página 1.631.
} 
No mesmo lugar dedicado por Cairu, José da Silva Costa expunha a classificação dos seguros, em marítimos e terrestres, logo no primeiro capítulo (Natureza do Contrato de Seguro) da primeira parte de sua obra (Seguro Marítimo). Talvez essa informação pudesse ser guardada sem que viesse a ocorrer algum prejuízo maior, pois a própria propaganda inserida pelos editores do Almanak informava essa divisão que, aliás, já seria notória somente pela tomada de conhecimento do título da obra. Mas, por outro lado, o que não pode deixar de ser ressaltado é que tudo parecia indicar a continuidade da preeminência do ramo dos seguros marítimos frente aos negócios contratados com base nos riscos terrestres, mesmo nas épocas em que a praça comercial do Rio de Janeiro presenciou um intenso funcionamento das companhias de seguros voltadas à garantia das atividades realizadas em terra - como foi o caso dos anos iniciados nos meados da década de 1860, quando essas seguradoras superaram, em número, as que garantiam os empreendimentos contra os riscos marítimos, fato que se estenderia, pelo menos, até $1888^{116}$.

Talvez porque a incorporação de uma companhia destinada a segurar os riscos do mar demandasse grandes somas de capital - o que bem poderia explicar o domínio estrangeiro no setor -, ou porque ela estivesse apta a captar maiores valores em prêmios e recolocá-los em circulação no comércio; ou talvez porque o ramo dos seguros terrestres vinha apenas se despontando numa sociedade, e num mercado, que começara a lhe proporcionar as primeiras oportunidades de negociações; pelo menos durante todo o século XIX o que pareceu ter se verificado mesmo fora a "preferência" pelos seguros marítimos. E esta situação estaria refletida pela doutrina jurídica de então.

De fato, se José da Silva Lisboa chegou a dedicar a totalidade de seu primeiro tratado aos seguros marítimos - salvo alguns poucos apontamentos relativos ao ramo dos seguros terrestres -, isso bem poderia denotar que os interesses dos comerciantes, e mesmo a riqueza dos Estados, estariam estritamente vinculados ao melhor ou pior encaminhamento que se dava ao comércio marítimo, pelo menos nos últimos anos do século XVIII e nos primeiros do XIX. Pareceu ter sido este o propósito do Visconde de Cairu com a publicação dos seus Princípios de Direito Mercantil e Leis de Marinha, se tomarmos em consideração o conteúdo de cada um dos outros sete tratados que compõem o conjunto da obra.

Por outro lado, na outra ponta do oitocentos, José da Silva Costa chegou a se empenhar sobre os seguros terrestres, mas o fez reservando apenas poucas páginas a estes

\footnotetext{
${ }^{116}$ Cf. Gráfico 11, p. 112.
} 
contratos. Sua obra Seguros Marítimos e Terrestres, publicada em 1883 e divulgada aos comerciantes da praça comercial do Rio de Janeiro, repartiu catorze capítulos à primeira parte (Seguro Marítimo), e apenas três à segunda (Seguro Terrestre). Mas, numa época em que a província já vinha suportando um número cada vez maior de seguradoras dedicadas à contratação dos riscos terrestres, o quinhão destinado a este ramo bem poderia revelar o reconhecimento de Silva Costa ao recrudescimento de um mercado carente de legislação que desse conta de regular as especificidades do negócio. Aliás, o espaço concedido ao instituto também poderia ser explicado pela própria natureza da obra, pois, em se tratando de uma doutrina jurídica - assim como tantas outras doutrinas coevas - buscava explicar o direito tomando por base a legislação sobre o assunto. E a legislação pátria relativa aos seguros terrestres, como sabido, era escassa.

Em pesquisa à Coleção das Leis do Império do Brasil (1808-1889) não nos deparamos com nenhuma Lei, Decreto, Aviso, ou qualquer outra norma que prescrevesse regras destinadas à contratação desses riscos. Essa ausência também fora notada pela própria doutrina publicada durante o século XIX, e é o que pode ser percebido quando em 1874 Cândido Mendes de Almeida diz que para os seguros terrestres "não temos legislação que o regule"117; e, cerca de dez anos mais tarde, quando José da Silva Costa afirmou que não enfrentamos sozinhos essa situação, pois "a deficiência que se observa na legislação pátria, quanto ao seguro terrestre, também é deplorada em vários países cultos" ${ }^{\text {"118. }}$.

Como se vê, passaram-se os anos, e chegado o fim do Império constatou-se que nem mesmo o Código Comercial do Brasil, promulgado em 1850, contemplou esta matéria. Somente se ocupou dos seguros marítimos, regulados especialmente no Título VIII - Dos seguros marítimos -, inserto em sua segunda parte - Do comércio marítimo. Nesse sentido, estaria muito próximo a todos os outros diplomas que lhe precederam, desde pelo menos o século XVIII.

\footnotetext{
${ }^{117}$ Cf. LISBOA, José da Silva, Visconde de Cairu, op. cit., p. 13, nota 2.

${ }^{118}$ Cf. COSTA, José da Silva, op. cit., p. 173.
} 


\section{CAPÍTULO 3: AS COMPANHIAS SEGURADORAS DE VIDA DE ESCRAVOS NO MERCADO CARIOCA}

\section{Dentre os seguros terrestres, o seguro de vida}

O mercado de seguros instalado na província do Rio de Janeiro foi marcado pela predominância de companhias dispostas a contratar sobre os perigos inerentes aos empreendimentos marítimos, pelo menos durante grande parte do oitocentos. Muito embora o surgimento de uma companhia seguradora de riscos terrestres tenha sido informado pela primeira vez somente no ano de $1843^{119}$ - quando até então o mercado caracterizar-se-ia pela presença exclusiva das seguradoras voltadas às negociações dos riscos provenientes do mar -, esse quadro perduraria até o início dos anos de 1860, quando começou a se inverter ${ }^{120}$. A partir já do segundo lustro da década, nunca mais o número de companhias que garantiriam o sucesso dos empreendimentos terrestres seria ultrapassado pelo de seguradoras voltadas às atividades marítimas ou fluviais. Mas, por outro lado,

\footnotetext{
119 Trata-se da Phenix Fluminense (16), apesar do Quadro Companhias de Seguros em funcionamento na Província do Rio de Janeiro (1808-1889) (cf. Anexo 2) afirmar que antes dela duas outras companhias já estariam contratando sobre os riscos terrestres: a Companhia de Seguros Marítimos Recuperadora (11), e a Companhia de Seguros Marítimos Nova Permanente (12). A primeira informação de que dispomos a respeito da Recuperadora proveio do Decreto n ${ }^{\circ} 791$, de 30 de maio de 1851. Apesar do ano de sua publicação não corresponder ao de 1837, como assim informa o Quadro, o artigo $6^{\circ}$ deste documento, contudo, afirma que a companhia completaria 15 anos de funcionamento no dia 7 de junho de 1852, o que nos permite deduzir a data em que iniciou suas atividades (07.06.1837). O mesmo documento ainda concederia à Recuperadora $\mathrm{O}$ prazo de 15 anos, a contar da data de sua publicação (30.05.1851), para que continuasse a funcionar sem que para isso necessitasse de pedir pela renovação da autorização imperial. No entanto, ao que parece, a companhia ainda estaria em funcionamento quando se aproximou o fim do Império (1888), porém, sob outra denominação. Essa mudança de nome se deu em virtude do Decreto $\mathrm{n}^{\mathrm{o}} 2.103$, de 6 de fevereiro de 1858, que aprovou "os novos Estatutos organizados para a Companhia Recuperadora, debaixo do nome de Fidelidade". Foi somente por esse mesmo documento que a companhia estivera autorizada a operar no setor dos riscos terrestres, portanto, somente no final da década de 1850. Já no que diz respeito à Companhia de Seguros Marítimos Nova Permanente, a primeira notícia acerca de sua existência pode ser conhecida no Decreto $\mathrm{n}^{\circ}$ 2.080, de 16 de Janeiro de 1858. Este documento não só informa que a companhia fora estabelecida na cidade do Rio de Janeiro no dia $1^{\circ}$ de junho de 1840 , como também nos diz que quando de sua fundação estaria autorizada a contratar nada além dos riscos provenientes da navegação marítima (artigo $1^{\circ}$, dos Estatutos anexos). Foi somente em 1875, com a publicação do Decreto $n^{\circ} 5.979$ de 11 de agosto, que lhe foi concedida a possibilidade de atuar no ramo terrestre (e só a partir do dia 4 de fevereiro de 1882, pelo Decreto $\mathrm{n}^{\circ} 8.398$, é que passou a segurar os riscos fluviais, ou de inundação). Diante de tudo isso, e segundo as fontes consultadas, a Phenix Fluminense, integrada na Companhia de Seguros contra fogo Argos Fluminense (20) por volta do ano de 1854, foi, dentre todas as seguradoras que chegaram a negociar os riscos terrestres na praça comercial do Rio de Janeiro, a pioneira. Para mais informações referentes às seguradoras, cf. o Quadro das Companhias de Seguros em funcionamento na Província do Rio de Janeiro (1808-1889), Anexo 2. Para a informação acerca da incorporação da Phenix Fluminense pela Argos Fluminense, cf. Almanak administrativo, mercantil e industrial do Rio de Janeiro - Almanak Laemmert, 1855, p. 360-361.

${ }^{120}$ Cf. Gráfico 11, p. 112.
} 
mesmo que esta superioridade numérica não refletisse a mesma posição a respeito da lucratividade do setor, o fato é que ao longo de todo o século XIX a praça comercial do Rio de Janeiro ofereceu oportunidades ao alargamento deste mercado. Cada vez mais companhias seriam estabelecidas e, nacionais ou estrangeiras, segurariam os particulares e os empreendimentos terrestres de uma variedade cada vez maior de riscos, sejam eles surgidos em decorrência da legislação que se transformava, ou das novas necessidades criadas pelo próprio mercado.

Os incêndios, por exemplo, que tanto decorreriam dos erros e descuidos humanos, como de igual modo poderiam ser provocados pelos acasos da própria natureza (raios), entraram para a pauta dos negócios realizados logo pela primeira seguradora de riscos terrestres estabelecida na província - a Phenix Fluminense (16), fundida na Companhia de Seguros contra fogo Argos Fluminense (20) em 1854 -, e também pela última - a Companhia de Seguro Mútuo Esperança $(143)^{121}$. Ao que parece, haveria grande interesse em segurar os prédios urbanos, ou mesmo os objetos guardados em seus interiores, dos danos ou da destruição pelo fogo. De todas as 81 companhias que chegaram a contratar sobre riscos terrestres, 42, portanto pouco mais da metade, dedicaram-se a garantir os eventuais prejuízos que os incêndios causariam às propriedades dos segurados. Mas, as perdas provocadas pelo fogo poderiam ir além das portas dos prédios, como quando algum deles estivesse arrendado pelos proprietários. Para essas situações em especial, outro número de seguradoras se disponibilizaram a resguardá-los do valor do aluguel durante o período necessário à reconstrução do edifício. Nesse ramo atuaria, por exemplo, a Companhia de Seguros Garantia dos Proprietários (91), que além de garantir o aluguel de prédios incendiados, seguraria também o aluguel de prédios não incendiados, tal como a Companhia de Seguros Marítimos e Terrestres Feliz Lembrança (44) - que em 1870 passou a se chamar Companhia Geral de Seguros União -, e a Associação de Seguro Mútuo Progresso (110).

Além dos incêndios, outros prováveis desastres naturais seriam objeto dos contratos realizados pelas companhias que foram se acomodando na província. $\mathrm{O}$ receio de que alguma chuva forte pudesse causar estragos ao que quer que fosse motivou parte dos negócios da Companhia de Seguros Marítimos e Terrestres (41) - ou Companhia de Seguro Marítimo Santa Cruz, a partir do Decreto no 2.572, de 14 de abril de 1860 -, que

\footnotetext{
${ }^{121}$ Os números seguidos aos nomes das seguradoras, e que vão entre parênteses, correspondem à posição de cada uma delas no Quadro Companhias de Seguros em funcionamento na Província do Rio de Janeiro (1808-1889, cf. Anexo 2.
} 
também segurava sobre os riscos de incêndios e inundações, assim como o faziam a Companhia de Seguros Marítimos e Terrestres Garantia (62), a Companhia de Seguros Marítimos e Terrestres Confiança (78), e a Companhia de Seguros Alliança (115). Voltada para os sinistros que poderiam acometer os campos de agricultura, em especial, a Companhia Monte Pio Agrícola (109) seguraria os prejuízos provocados pelas chuvas de pedra, pelas secas, e também pelas geadas.

Empreendimentos como o do transporte terrestre de mercadorias também comporiam a relação dos riscos contratados pelas companhias seguradoras, principalmente a partir de meados do século. A este ramo estariam dedicadas, dentre outras, a própria Companhia de Seguros Marítimos e Terrestres (41), a Companhia de Seguros Marítimos e Terrestres Fidelidade (11) - antiga Companhia de Seguros Marítimos Recuperadora -, a Companhia de Seguros Nova Permanente (12), e a Companhia Brasileira de seguros sobre a vida que, dois anos após o início de suas atividades, em 1873, passa a ser chamada Companhia Brasileira de Seguros Gerais O Palladio $^{122}$ (76). Os veículos mesmos, utilizados para o transporte ou para a condução, e também os animais que os movimentariam, seriam todos riscos segurados pela Companhia de Seguros Apollo (90), cuja data da única informação noticiada a respeito de sua existência seria a do ano de $1874^{123}$. Um ano mais tarde, em 1875 , o seguro sobre o risco de falência passaria a ser oferecido na praça comercial do Rio de Janeiro. Dentre outros serviços, a Companhia de Seguros Garantia e Proteção Mútua (97) estaria disposta a correr em auxílio dos falidos.

Por essa época, a província pode presenciar o surgimento de novos riscos, e, portanto, o consequente estabelecimento de companhias autorizadas a segurá-los. Muito provavelmente em decorrência dos efeitos da Guerra do Paraguai, iniciada em 1864 e que se estenderia por cerca de seis anos, o fato é que novas seguradoras dispostas a contratar sobre os riscos do recrutamento militar começaram a despontar no cenário comercial do Rio de Janeiro, principalmente durante o decênio de 1870. O risco do recrutamento existira, e tinha sido criado pela legislação de meados da década. Já no ano de 1875 , a Companhia de Seguro Mútuo sobre o Recrutamento (95), incorporada no mês de setembro, teria por finalidade "garantir mutuamente seus membros ou aqueles quem estes segurarem contra as eventualidades do alistamento e do sorteio para o serviço militar, criadas pela Lei

\footnotetext{
${ }^{122}$ Cf. Decreto $n^{\circ} 5.246$, de 5 de abril de 1873 .

${ }^{123}$ Cf. Decreto $n^{\circ} 5.729$, de 27 de agosto de 1874.
} 
$\mathrm{n}^{\mathrm{o}} 2.556$ de 26 de Setembro de 1874 e Decreto $\mathrm{n}^{\mathrm{o}} 5.881$ de 27 de Fevereiro de $1875^{, 124}$. Dentre outros serviços, a companhia promoveria a "isenção por meio da contribuição pecuniária" (art. $1^{\circ}, \S 3^{\circ}$ dos Estatutos), conforme previa o artigo 69 do Decreto $n^{\circ} 5.881$; a "substituição pessoal (art. $1^{\circ}, \S 4^{\circ}$ dos Estatutos), facultada pelo artigo 71 do mesmo diploma legal; e, "a efetividade da substituição pessoal, isto é, assumindo a responsabilidade pela deserção do substituto no primeiro ano de praça", (art. $1^{\circ}, \S 5^{\circ}$ dos Estatutos) ${ }^{125}$. Ainda no mesmo ano de 1875, a garantia de isenção do serviço militar passaria a ser contratada por mais seguradoras estabelecidas no Rio de Janeiro, seja por aquelas recém incorporadas, como por exemplo a Companhia de Seguros Garantia e Proteção Mútua $(97)^{126}$ e os Seguros para isenção do Serviço Militar (anexos à Caixa Geral de economias da Mutualidade) (94); seja por aquelas antigas, mas que vislumbraram alguma possibilidade de se obter lucros com o novo negócio, como ocorreu com a Companhia de Seguros Garantia dos Proprietários (91) que, embora estabelecida no ano anterior (1874), somente foi autorizada a segurar os riscos do sorteio militar no ano seguinte, mediante a publicação do Decreto n ${ }^{\circ} 6.054$, no 13 de dezembro ${ }^{127}$. Em 1876, duas novas seguradoras passaram a atuar nesse ramo do mercado, a Companhia Conscripção ${ }^{128}$ (100) e a Companhia de Seguros Resgate Militar (106). E em 1878, a Companhia de Seguros Mútuos sobre a vida e contra o fogo Mutualidadel Associação Brasileira

${ }^{124}$ Cf. Decreto n ${ }^{\circ} 5.984$, de 8 de setembro de 1875 . A citação é um trecho extraído do art. $1^{\circ}$ dos Estatutos da companhia, publicados em anexo ao documento.

${ }^{125}$ Todos esses compromissos firmados pela Companhia de Seguro Mútuos sobre o Recrutamento, como se vê, seriam motivados pelo próprio texto do Decreto. O artigo 69 deste documento previa a isenção do sorteado mediante o pagamento de certa quantia de valor: "É permitido ao sorteado isentar-se por meio de contribuição pecuniária marcada em Lei, contanto que reúna e demonstre com documentos e provas jurídicas as seguintes condições: $1^{\mathrm{a}}$. Não ter sido capturado por falta de comparecimento a que fosse obrigado em virtude de sorteio; $2^{\mathrm{a}}$. Estar servindo como caixeiro ou empregado em alguma casa ou estabelecimento comercial, bancário, industrial ou agrícola; $3^{\mathrm{a}}$. Aplicar-se com proveito, ou exercer efetivamente alguma indústria ou ocupação útil; $4^{\mathrm{a}}$. Estudar alguma ciência, ou arte liberal, tendo já sido aprovado em algumas dessas matérias. Parágrafo único: Depois de verificado o assentamento de praça não se pode mais fazer a exoneração pecuniária, salvo o disposto no art. $110 \S 2^{\circ}$." O artigo 71, previa uma outra maneira do sorteado se ver livre da obrigação de servir ao Exército: "É permitido ao sorteado fazer-se substituir por outro indivíduo logo depois do sorteio, ou dentro de um ano de praça, contanto que o substituto reúna os seguintes requisitos: $1^{\circ}$. Robustez física e necessária para o serviço militar; $2^{\circ}$. Ter 17 anos completos e nunca mais de 30, salvo se tiver servido no Exército ou Armada, caso em que poderá ser admitido até os 35 anos; $3^{\circ}$. Se for menor de 21 , autorização de seu pai ou tutor; $4^{\circ}$ Apresentar folha corrida; $5^{\circ}$. Ter a precisa moralidade. Parágrafo único: $O$ estrangeiro não pode ser substituto, exceto se já tiver completado com regular procedimento o seu tempo de serviço como praça voluntária". Em continuação ao assunto, o artigo 72, que motivara o compromisso marcado no $\S 5^{\circ}$ do primeiro artigo dos Estatutos da companhia, dizia: "O que apresentar substituto, e este for aceito, assinará termo de responsabilidade pela deserção do mesmo substituto no primeiro ano de praça"; cf. Decreto n ${ }^{\circ} 5.881$, de 27 de fevereiro de 1875.

${ }_{126}$ Cf. Decreto $\mathrm{n}^{\circ} 6.032$, de 6 de novembro de 1875.

${ }^{127}$ A Companhia de Seguros Garantia dos Proprietários fora autorizada a funcionar na praça carioca pelo Decreto $n^{\circ} 5.789$, de 11 de novembro de 1874 . Constatados vários problemas na administração da empresa, ela teve sua autorização cassada em 1878 , pelo Decreto ${ }^{\circ} 6.968$, do dia 13 de julho.

${ }^{128}$ Cf. Decreto ${ }^{\circ} 6.099$, de 19 de janeiro de 1876. 
Mutualidade (81), em funcionamento desde pelo menos 1872, foi autorizada a segurar o risco do recrutamento para o Exército, concessão feita mediante a publicação do Decreto $n^{\circ}$ 7.044 , de 12 de outubro ${ }^{129}$.

O sorteio para o recrutamento, regularizado pela legislação imperial, acabou por se constituir num risco, de fato, e fora reconhecido como tal. A sorte em se escapar ao alistamento poderia não se fazer presente aos cidadãos que, se designados, deveriam compor as fileiras do Exército. A simples possibilidade, portanto, de um evento não desejado ocorrer em prejuízo de alguns interesses, por si só explicaria a legitimidade das contratações realizadas pelas companhias seguradoras que se dedicaram a esse negócio. Por outro lado, esse mesmo entendimento acerca dos requisitos dos contratos de seguro serviria de justificativa à proibição dos seguros feitos a favor da integralidade dos prêmios lotéricos.

Os bilhetes de loteria, ou melhor, os prêmios dos ganhadores, chegaram a ser garantidos contra o desfalque ocasionado pelo imposto a que estariam sujeitos, ainda que por um breve intervalo de tempo durante os anos de 1870. Dentre as companhias dedicadas ao negócio estariam a Loterias Legais (88), cuja primeira informação a respeito de sua existência data de 1873, e a última, de 1876; e a Companhia Lotérica de Seguros (87). A autorização concedida ao funcionamento desta última seguradora acabou sendo cassada em 1878, quase cinco anos após ter iniciado suas operações na Corte e na província do Rio de Janeiro. O Decreto $n^{\circ}$ 6.972, responsável pela extinção de suas atividades, não o fez motivado pela condenação dos atos dos administradores da empresa, como outrora ocorrera com a Garantia dos Proprietários e com a Mutualidade; mas, pelo contrário, pela condenação da própria natureza do negócio. Para tanto, pelo texto do documento dizia-se que "o imposto a que estão sujeitos os prêmios da loteria é uma obrigação legal, que não está sujeita a contingências, que constituem risco para ser garantido por contrato de seguro" ${ }^{130}$. O contrato de seguros, como era sabido, só poderia existir se recaísse sobre algum objeto passível de ser acometido pela ocorrência de qualquer sinistro: "não pode ser objeto de seguro senão aquilo que corre risco de perder-se", o que não viria a ser o caso, pelos termos do Decreto, dos prêmios concedidos pelas loterias do Estado.

129 A Companhia de Seguros Mútuos sobre a vida e contra o fogo Mutualidadel Associação Brasileira Mutualidade fora incorporada pelo Decreto $\mathrm{n}^{\circ} 4.987$, de 19 de janeiro de 1872, porém, na ocasião somente fora autorizada a estabelecer uma associação de seguros mútuos sobre a vida, e contra o fogo. Por má gerência de seus administradores, a companhia teve sua autorização cassada em 1882, pelo Decreto ${ }^{\circ} 8.446$, de 8 de março.

${ }^{130}$ Cf. Decreto $n^{\circ}$ 6.972, de 20 de julho de 1878. Esta citação e as que virão com o parágrafo, são trechos extraídos deste documento. 
Mas os seguros contratados para a garantia da integralidade dos prêmios lotéricos não foram os únicos a enfrentar alguma resistência no mercado que ia se conformando durante os idos do século XIX. A vida, por ser considerada um bem inegociável, e que por essa razão deveria ser guardada fora do alcance do comércio, não poderia ser objeto dos contratos de seguros. Já em fins do século XVIII, segundo as palavras de José da Silva Lisboa, o Visconde de Cairu, "o Seguro de vida, por parecer contrário à dignidade do homem, e de mau agouro; porque pode dar ocasião a celerados a cometerem enormes delitos, para a destruição da existência dos Segurados"131; não estaria permitido em muitas nações civilizadas. Dentre elas, o Brasil, cerca de cinquenta anos depois, desautorizara-o expressamente no seu Código Comercial ${ }^{132}$ promulgado em 1850. Dizia o artigo 686, 2, deste documento, que "É proibido o seguro (...) sobre a vida de qualquer pessoa livre". Passariam os anos e o valor dantes previsto ainda persistiria, se não nas mentes de muitos negociantes e alguns juristas, ao menos dentre os membros da sociedade. Pelo menos é o que se pode denotar do que escrevera José da Silva Costa às vésperas da queda do Império. Dizia ele em 1883 que

O seguro de vida tem sido vivamente impugnado, principalmente pela consideração de que a vida é inestimável, está fora das transações de qualquer espécie e natureza, além de ser odioso contratar, tomando como base do cálculo ou probabilidade o óbito da pessoa. ${ }^{133}$

Mas, por outro lado, pelo que fazem notar as negociações presenciadas pela praça comercial do Rio de Janeiro, principalmente as que ali tomaram lugar durante a segunda metade do século, esta proibição não seria completamente respaldada pelo mercado carioca. Talvez decorrente de certa interpretação restritiva que se fazia da letra da lei, ou talvez devido a um entendimento peculiar acerca deste negócio, a vida das pessoas livres, ao que tudo indica, de alguma forma chegou a ser objeto de contratos de seguro, pelo menos em algumas de suas modalidades.

O mesmo José da Silva Costa, advogado e jurista, compreendera que uma interpretação extensiva da proibição expressa no Código Comercial não estaria refletindo o verdadeiro espírito da lei. Esta, de fato, considerara que "não sendo a vida da pessoa livre objeto de comércio marítimo, não podia figurar como matéria alimentante do seguro". Contudo, o "legislador não quis vedar, por certo, que a vida de qualquer pessoa livre, a

${ }^{131}$ Cf. LISBOA, José da Silva, Visconde de Cairu, Princípios de direito mercantil e leis de marinha, p. 44.

132 Trata-se da Lei n ${ }^{\circ} 556$, de 25 de junho de 1850.

${ }^{133}$ Cf. COSTA, José da Silva, Seguros marítimos e terrestres, p. 187. 
certo respeito, fosse objeto de outra espécie de seguros" ${ }^{\text {134 }}$. Interpretou restritivamente a prescrição do artigo 686, 2, portanto, de modo a justificar a tomada da vida por inúmeras seguradoras estabelecidas na província do Rio de Janeiro, para que servisse ao sustento de seus negócios ${ }^{135}$.

Pelo que demonstrara, Costa não compreendia tamanha ojeriza pelo seguro de vida, ainda mais porque entendia que o negócio existia para o benefício da própria sociedade. Argumentava que muitas privações, e muitas pauperizações, poderiam ser evitadas se o pai, o tutor, o esposo, enfim, pensando no seu próprio futuro e no daqueles que viviam aos seus cuidados, poupasse ao longo da vida toda, pouco a pouco, ano a ano, "e ver as economias da mocidade e idade madura crescerem sucessivamente e se constituírem riqueza na velhice"136. Mas esta seria tarefa por si só muito arriscada. Não só pelas inúmeras tentações que muito provavelmente fariam o poupador gastar o montante acumulado, atacando-o em breves momentos de fraqueza, ou de necessidades mesmo; mas também porque a qualquer instante poderia sobrevir a morte repentina, e prematura, do pai de família, antes que conseguisse guardar o valor planejado, tão indispensável ao sustento de seus dependentes.

Talvez nisso residisse a vantagem dos serviços prestados pelas companhias de seguros de vida: a de que a esposa, ou o órfão, pudessem a qualquer momento ser beneficiados por uma quantia não necessariamente proporcional ao período em que o marido, ou o pai, limitou-se a poupar. E talvez por isso o jurista preferira considerar o objeto do seguro de vida, não a vida, ou a morte em si; "mas uma certa quantia, em forma de pensão vitalícia ou capital adiado, sob a condição da vida em um período dado ou da morte inesperada" 137 . E preferira, de igual modo, fazer uso dos termos "seguros em caso de vida" e "seguros em caso de morte" - ao invés de simplesmente "seguros de vida" - para

\footnotetext{
${ }^{134}$ Ibidem, p. 42

${ }^{135}$ Nesse sentido, Luís Mendonça menciona que “(...) em 1850, com o Código Comercial, baixaram-se normas sobre seguro marítimo. Nesse código, havia a proibição de que se fizesse seguro de vida de homens livres, daí resultando, é claro, que só se poderia fazer seguro de vida sobre escravo. (...) Mas houve juristas, na época, que tiveram uma interpretação cavilosa: o código regulava transporte marítimo e, logo, as suas prescrições só se aplicavam ao transporte. Então, quem estivesse em terra podia fazer seguro de vida. Só não podia fazer seguro de vida quem estivesse no mar como passageiro", cf. MENDONÇA, Luís, Luís Mendonça (depoimento, 1996), p. 4-5. Pelo que se pode perceber, a "interpretação cavilosa" que Mendonça atribui a alguns juristas do oitocentos é na verdade uma interpretação restritiva do texto da lei. Por esse entendimento, os seguros sobre a vida de qualquer pessoa livre, quando contratados em terra, estariam desimpedidos legalmente, pois, como é sabido, o Código Comercial somente prescreva sobre a vida de pessoas livres, quando sujeita à navegação marítima. De fato, nos termos da organização formal da lei, o artigo 686, 2, situase no Capítulo II - Das coisas que podem ser objeto de seguro marítimo -, subordinado ao Título VIII - Dos seguros marítimos -, inserto na segunda Parte do Código - Do comércio marítimo.

${ }^{136}$ Cf. COSTA, José da Silva, op. cit., p. 188.

${ }^{137}$ Ibidem, p. 188.
} 
se referir aos contratos negociados por companhias como a Sociedade de Seguros Mútuos sobre a vida Protetora das Famílias (61), gerida pelo Banco Rural e Hipotecário; a Sociedade Brasileira de Seguro Mútuo sobre a vida Bemfeitoria (67), gerida pelo Banco Comercial do Rio de Janeiro; a Companhia Brasileira de seguros sobre a vida/ Companhia Brasileira de Seguros Gerais $O$ Palladio (76), todas as três destinadas à criação de capitais e rendas; ou como a Companhia de Seguros Mútuos sobre a vida Tutora Brasileira (46) e a Companhia de Seguros União Comercial (113) que, além de se disponibilizarem à criação de capitais e rendas, contribuíram para a formação de dotes e heranças, a primeira; e dotes, heranças e pensões, a segunda; ou, ainda, como a Companhia de Seguros Marítimos e Terrestres Fidelidade (11) - antiga Companhia de Seguros Marítimos Recuperadora -, que, somados aos seguros contra incêndios e acidentes decorrentes do transporte terrestre, também auxiliaria na formação de pensões, dotes e heranças.

Todas elas estiveram em funcionamento na praça comercial da província do Rio de Janeiro durante, pelo menos, a segunda metade do século XIX, e ofereceriam seus serviços sem que quaisquer impedimentos legais acabassem por se tornar obstáculos incontornáveis ao bom andamento de suas atividades. E todas elas, como se vê, organizariam seus negócios à semelhança do que em dias atuais se entende pelas operações previdenciárias. A criação de capitais, rendas, dotes, pensões ou heranças, tudo isso reservaria aos segurados e seus beneficiários certo conforto na velhice, ou o sustento em épocas difíceis. Todas essas operações, ao que tudo indica, seriam em algum grau distintas das que proibira o artigo 686, 2, do Código Comercial. E o funcionamento de todas essas companhias seguradoras, por conseguinte, em nada desacreditaria a validade e a aplicação da Lei. Pelo menos aparentemente.

Por outro lado, quando em 1798 José da Silva Lisboa noticiara que "em alguns países se costuma segurar a vida dos homens, e das bestas, ainda quando não são expostas aos perigos da navegação”, Cândido Mendes de Almeida, seu comentador em 1874, numa nota ao pé da página observou que "esta espécie de Seguros é também hoje usada entre nós, mas com relação aos escravos"138. Se à época da publicação da sexta edição dos Princípios de direito mercantil e leis de marinha o mercado estabelecido na província do Rio de Janeiro já vinha presenciando a atuação de companhias ou sociedades voltadas às negociações de seguros sobre a vida, pelo menos sobre as espécies mencionadas anteriormente, isso nos permite depreender que ambos, tanto Lisboa como Mendes de

${ }^{138}$ Para ambas as citações, cf. LISBOA, José da Silva, Visconde de Cairu, op. cit., p. 13. O comentário de Cândido Mendes de Almeida compõe a nota de número 3. 
Almeida, muito provavelmente estariam tratando do seguro contratado para que certa indenização fosse paga ao beneficiário caso sobreviesse a morte de alguém - ou o "seguro de vida" tal qual comumente se conhece -, este sim, a espécie proibida pelo Código.

A proibição, conforme prescrevia o texto da Lei, bem poderia ter sido o entendimento dos coevos acerca da possibilidade, ou não, destas contratações constituírem os negócios das companhias de seguros estabelecidas na praça comercial do Rio de Janeiro, e também nas outras praças comerciais do Império. Contudo, pelo menos no que diz respeito à doutrina jurídica da segunda metade do século XIX, esta harmonia estaria longe de ser consolidada; e isso pode ser percebido pela discussão que foi se avolumando em torno do Decreto que autorizou a incorporação da Companhia de Seguros Tranquilidade (39), em 1855, portanto passados apenas cinco anos da promulgação do Código Comercial ${ }^{139}$.

O Decreto $\mathrm{n}^{\mathrm{o}} 1.669$, de 7 de novembro, fora instrumento pelo qual o governo imperial atendera positivamente ao requerimento de Bernardo de Oliveira Mello e de Luiz Carlos Adolpho de Sousa, "fundadores e instaladores", e também gerentes da companhia. Mas seria especificamente o artigo 33 de seus Estatutos, aprovados e publicados em anexo ao mesmo documento, que daria margem a interpretações permissivas à contratação dos seguros de vida de pessoas livres, como poderiam defender alguns, em detrimento do que prescrevia o Código Comercial. Dizia ele:

Art. 33. Sendo o seguro de vida reconhecido por todas as Nações da Europa e pelos Estados-Unidos da América do Norte, como um benefício geral para a humanidade, esta companhia [a Tranquilidade] no caso que não vá de encontro às Leis que regem o Império, se destinará a tomar o mesmo risco sobre pessoas

\footnotetext{
139 No que diz respeito à Companhia de Seguros Tranquilidade ser considerada a primeira seguradora autorizada a operar sobre os seguros de vida, especificamente em sua espécie proibida pelo Código Comercial, essa informação, além de ser uma das conclusões que pudemos extrair das fontes consultadas, também é compartilhada pela doutrina, ou mesmo pelos manuais, publicados no decorrer do século XX. Por exemplo, Itagypa lembra, em sua obra vinda a lume no ano de 1900, que o Decreto $\mathrm{n}^{\circ} 1.669$ de 7 de novembro de 1855 é "a primeira disposição legal, emanada do poder público, que temos de memória, autorizando o funcionamento de companhia de seguro sobre a vida das pessoas no Brasil”, cf. ITAGYBA, J. Nogueira, Tratado sobre seguros de vida, p. 40. A mesma informação pode ser encontrada na publicação número 15 do INSTITUTO DE RESSEGUROS DO BRASIL, Noções Fundamentais de Seguros (1944), p. 21; e na obra de ALVIM, Pedro, O Contrato de Seguro (2001, $3^{\mathrm{a}}$ ed.), p. 52. Por outro lado, ao que parece a Companhia de Seguros Tranquilidade não chegou a ser estabelecida por seus fundadores, apesar de ter sido autorizada a funcionar, e de ter seus Estatutos aprovados pelo governo imperial. Foi um caso isolado ocorrido no ramo segurador entre 1850 e 1865, cf. Relatório da comissão encarregada do 1 de outubro e de 28 de dezembro de 1864 de proceder a um inquérito sobre as causas principais e acidentais da crise do mês de setembro de 1864 (publicado em 1865 pela Tipografia Nacional) apud SAES, Alexandre Macchione; GAMBI, Thiago Fontelas Rosado, A Formação das companhias de seguros na economia brasileira (18081864), p. 13, 16. Contudo, muito embora a Tranquilidade não tenha exercido suas atividades no mercado carioca do século XIX, sua presença se fez notada e sentida nos debates jurídicos coevos travados em torno da possibilidade, ou não, de se tomar a vida de pessoas livres como objeto dos contratos de seguros.
} 
livres de ambos os sexos e idades, para o que nesta hipótese haverá disposições especiais, que ficam sujeitas à aprovação Imperial. ${ }^{140}$

O texto do dispositivo é claro, como se vê, ao estabelecer que os administradores da Companhia de Seguros Tranquilidade não poderiam iniciar as negociações sobre o seguro de vida de pessoas livres. Os Estatutos anexos ao Decreto de 1855 não chegaram a regulamentar o seguro de vida, e o seu $33^{\circ}$ artigo apenas concedera à companhia uma autorização prévia, uma possibilidade de negociá-lo, desde que por observância a disposições que deveriam ser encaminhadas e aprovadas pelo governo imperial, em uma oportunidade futura. Mas, mesmo assim, houve quem o tomasse sob um contexto mais amplo, digamos, o que lhe proporcionaria o entendimento pela liberdade da contratação sobre os riscos de morte.

Este pareceu ser o caso da doutrina defendida pelo Dr. Salustiano Orlando de Araújo $\operatorname{Costa}^{141}$ em todas as cinco edições dos seus comentários ao Código Comercial do Império do Brasil, obra de suma relevância e que servira aos juristas coevos como importante fonte de conhecimento do direito comercial durante a segunda metade do século XIX. Acabaria por se constituir numa referência, mesmo. Quando no ano de 1886 os editores do Almanak Laemmert propagandearam a obra de José da Silva Costa, Seguros marítimos e terrestres, publicada três anos antes, diziam que "este livro não deve faltar em escritório comercial algum, [e que] o seu lugar é ao lado do Código Comercial de Orlando, obra que já encontra-se sobre a mesa de trabalho dos Negociantes afim de evitar, por ignorância de disposição da Lei, prejuízos enormes"142. A menção dada á obra pela Casa editorial, por sinal, ocorrera no mesmo ano em que Salustiano Orlando publicara a quarta edição de seus comentários ao Código, esta, então, "mais correta e consideravelmente aumentada", segundo as palavras de Sacramento Blake ${ }^{143}$.

\footnotetext{
${ }^{140}$ Cf. Decreto n 1.669 de 7 de novembro de 1855.

${ }^{141}$ Salustiano Orlando de Araújo Costa nasceu a 8 de junho de 1834 na cidade de São Cristovão, situada onde hoje seria o Estado de Sergipe. Formou-se em Direito pela Faculdade de Recife, e chegou a ocupar os cargos de Promotor, Desembargador dos Tribunais de Relação do Pará e do Rio Grande do Sul, e Chefe de Polícia do Ceará e Amazonas, onde também foi Diretor da Instrução Pública. Chegou a ser Deputado provincial por Sergipe, e representando o Rio Grande do Sul foi designado para compor a Constituinte republicana, em 1890. Cf. BLAKE, Augusto Victorino Alves Sacramento, Diccionário Bibliographico Brasileiro, vol. 7, p. 185.

${ }^{142}$ Cf. Almanak administrativo, mercantil e industrial do Rio de Janeiro - Almanak Laemmert, 1886, p. 1.645 .

${ }^{143}$ Cf. BLAKE, Augusto Victorino Alves Sacramento, op. cit., vol. 7, p. 185. O mesmo autor, no mesmo Diccionário, dá notícias das edições que foi ganhando a obra de Salustiano Orlando de Araújo Costa no decorrer da segunda metade do século XIX: a $1^{\text {a }}$ edição veio a lume no mesmo ano em que a praça comercial do Rio de Janeiro sofreu com a crise que ali se estabeleceu, em 1864; a $2^{\text {a }}$ foi publicada cerca de cinco anos depois, em 1869; a $3^{\text {a }}$ edição é de 1878; a 4 $4^{\text {a }}$, conforme mencionado anteriormente, é de 1886; e passada cerca
} 
Contudo, foi pela terceira edição, que saiu no ano de 1878, quando então ocupava os cargos de Juiz dos Feitos da Fazenda e de Juiz Comercial na capital da província de S. Pedro do Rio Grande do Sul, que Salustiano Orlando rebateria, pela primeira vez, algumas das críticas dirigidas à obra de tamanho porte, especialmente aquelas que atacaram seu posicionamento acerca dos seguros sobre a vida de pessoas livres. Antes disso, no entanto, reafirmaria sua opinião em relação à possibilidade de se contratar os seguros de vida. Dizia ele, em nota ao segundo parágrafo do artigo 686 do Código Comercial, que "entre nós devemos reputar este parágrafo também sem préstimo, quanto aos seguros terrestres; aí estão na Corte funcionando companhias de seguros de vida; e o próprio Governo Imperial, no Dec. n. 1669 de 1855, art. 33" ${ }^{144}$, se não chegou a confirmar este negócio dentre as operações da Companhia de Seguros Tranquilidade, acabou por reconhecer que a proibição imposta pela lei, se não careceria de legitimidade, pelo menos não vinha sendo observada nas negociações que se faziam no mercado da província ${ }^{145}$.

Somente depois de ter reafirmado a sua posição primitiva é que responderia à contestação que lhe fizera Annibal André Ribeiro ${ }^{146}$ alguns anos antes. Este jurista, em 1871, publicara suas Breves observações ${ }^{147}$ a respeito das opiniões insertas na primeira e segunda edições do Código comentado por seu colega e, especialmente sobre o tema em discussão, defendia que somente com a revogação expressa do artigo 686, 2, do Código

de uma década, chega a $5^{\text {a }}$ edição, em 1896. "Esta última edição, que por erro tipográfico traz na página três o número de - sexta - está ampliada com o decreto n. 2163, de 9 de novembro de 1895 , sobre a taxa judiciária do distrito federal, com a lei francesa modificativa da lei de 24 de julho de 1867 sobre as sociedades por ações e com a lei francesa de 4 de março de 1889, modificando a legislação das falências", ibidem.

${ }^{144}$ Cf. SALUSTIANO ORLANDO de Araújo Costa, Código Comercial do Império do Brasil. $3^{\mathrm{a}}$ ed, p. 317 , nota 1066.

145 Salustiano Orlando também encontraria guarida para sua opinião num campo que extrapolaria o propriamente jurídico: "Na Inglaterra e nos Estados-Unidos existem muitas companhias com esse fim: na França, atualmente, existem também muitas. Acabou o preconceito que a vida não é uma coisa ou valor apreciável a dinheiro, que não está no comércio, e que é odioso que a possibilidade da morte de um indivíduo possa tornar-se o objeto de uma especulação. O governo francês compenetrou-se de que, bem longe de ser contrário à ordem pública o seguro de vida, ele oferece um caráter de moralidade, garantindo a velhice ao próprio segurado, e aos seus herdeiros meios de subsistência", cf. SALUSTIANO ORLANDO de Araújo Costa, op. cit., p. 316-317, nota 1066.

146 Annibal André Ribeiro nasceu na Bahia em 30 de novembro de 1835, e bacharelou-se em 1855 na Faculdade de Direito de Recife. Exerceu a advocacia até 1865. Em janeiro de 1864 foi nomeado oficial-maior da Secretaria do Tribunal do Comércio da Bahia até que, com a extinção da jurisdição especial, foi nomeado Secretário da Junta Comercial de São Salvador, pelo Decreto de 14 de fevereiro de 1877. Publicou, dentre outras obras, Pecúlio do procurador de segunda instância, em 1867; Apontamentos sobre o registro público do comércio, em 1868; Instrução para as eleições dos deputados e suplentes dos tribunais do comércio, em 1872; e Regulamento do imposto de transmissão de propriedade, no ano seguinte. Cf. BLAKE, Augusto Victorino Alves Sacramento, op. cit., vol. 1, p. 98.

${ }^{147}$ Trata-se de sua obra Breves observações sobre as anotações do Dr. Salustiano Orlando de Araújo Costa ao Código Comercial do Império do Brasil. Confira maiores detalhes desta publicação dentre as obras que foram Referências à dissertação. 
Comercial é que a questão estaria resolvida de uma vez por todas. Além de se colocar contrário à revogação tácita do dispositivo, esta sugerida por Salustiano Orlando, de igual modo colocar-se-ia em oposição ao entendimento de seu interlocutor, segundo o qual justificaria a possibilidade de se contratar os seguros de vida pela simples constatação de que na Corte já estariam em funcionamento inúmeras companhias voltadas à realização deste negócio. Quanto a este ponto, o argumento de Annibal André Ribeiro denunciaria sua divergência, agora em relação à natureza mesma dessas seguradoras que tomavam lugar na praça comercial do Rio de Janeiro. Fora seu parecer:

\begin{abstract}
Cumpre observar, que não se pode considerar sem execução o cit. art. 686 n. 2, por existir alguma companhia ou sociedade, que tenha por fim, mediante contribuições dos sócios, e auxiliadas pelas probabilidades de mortes de um certo número destes dentro dos prazos estipulados, aumentar capitais e formar rendas em favor dos sócios sobreviventes; porquanto tal associação é uma espécie de Montepio, e suas operações não são os contratos de seguro regulados pelo Código. Dessa natureza é por exemplo, a sociedade brasileira de seguro mútuo sobre a vida, denominada - Bemfeitoria - cujos estatutos foram aprovados pelo Dec. n. 4104 de 22 de Fevereiro de $1868 .^{148}$
\end{abstract}

Salustiano Orlando, por sua vez, replicaria este entendimento do jurista, acusando que, na verdade, as “companhias de seguro mútuo sobre a vida estão funcionando e o disfarce de espécie de montepio não pode colher: - que importam que tenham por fim fazer capitais e rendas tais associações, se de fato seguram a vida de pessoas livres?!"149. Nesse sentido, o dispositivo do Código seria, de fato, letra morta. E a autorização concedida à Tranquilidade, mediante o Decreto $\mathrm{n}^{\circ} 1.669$ de 1855 , poderia muito bem ter refletido a ineficácia da lei.

Além disso, nesse mesmo Decreto residiria outro ponto de divergência entre os dois. A maneira como o artigo 33 dos Estatutos da companhia foi tomado por Salustiano Orlando, ao que parece, provocou certo incômodo a Annibal André Ribeiro. Este acusara o colega de considerar o conteúdo do dispositivo como se procedesse do próprio Decreto, ao invés de ter sido sugestão dos fundadores e instaladores da companhia, esperando a aprovação do governo. Se assim fosse, significaria o mesmo que dizer ter sido o artigo 33 “declaração do Governo Imperial, que certamente não a faria como está", ${ }^{150}$, provavelmente por ir de encontro à prescrição do Código. Mas, de um modo ou de outro, se o Decreto $\mathrm{n}^{\circ}$

\footnotetext{
${ }^{148}$ Cf. RIBEIRO, Annibal André, Breves observações sobre as anotações do Dr. Salustiano Orlando de Araújo Costa ao Código Comercial do Império do Brasil, p. 108-109.

${ }^{149}$ Cf. SALUSTIANO ORLANDO de Araújo Costa, op. cit., p. 317, nota 1066.

${ }^{150}$ Cf. RIBEIRO, Annibal André, op. cit., p. 108.
} 
1.669 aprovou os Estatutos da Companhia de Seguros Tranquilidade sem nenhuma modificação, consequentemente seria porque o governo nada teria a opor à pretensão de Bernardo de Oliveira e Mello e de Luiz Carlos Adolpho de Sousa.

Além disso, Cândido Mendes de Almeida, mesmo não tendo participado diretamente deste debate, anotara algo que bem poderia vir em auxílio de Annibal André Ribeiro, posto que abalaria um dos pilares da argumentação de Salustiano Orlando. Sua observação giraria em torno do valor atribuído ao Decreto, enquanto fonte legislativa, frente às demais fontes normativas legitimadas pela organização do Estado Imperial. Dizia ele que

\footnotetext{
o Dec. $\mathrm{n}^{\circ} 1.669$ - de 7 de Novembro de 1855, art. 33, aprovando a Companhia de Seguros Tranquilidade parece estar em desacordo com a presente disposição [artigo 686, 2, do Código Comercial], mas sendo um Dec. do Poder Executivo tão somente, não poderia invalidar tão positiva determinação. ${ }^{151}$
}

Contudo, se o que foi dito por cada um dos juristas vinha contribuindo, de algum modo, para que algo fosse esclarecido acerca da possibilidade de se contratar os seguros de vida na província do Rio de Janeiro, o que eles não disseram só fez aumentar ainda mais a confusão em torno deste negócio. Nem Salustiano Orlando, nem Annibal André Ribeiro, nem Cândido Mendes de Almeida, nenhum deles, embora tenham publicado suas obras no decorrer da década de 1870, nenhum deles chegou a comentar a aprovação das "alterações e adições propostas aos Estatutos" da Companhia de Seguros Tranquilidade, baixadas com o Decreto $\mathrm{n}^{\circ} 2.101$, de 6 de fevereiro de 1858, que basicamente acresciam parágrafos adicionais ao artigo 33 de seus Estatutos aprovados em 1855, regulamentando, e por conseguinte autorizando a seguradora a iniciar as negociações sobre seguros de vida de pessoas livres.

Também nada disseram a respeito dos seguros que a companhia fora autorizada a contratar logo da aprovação de seus Estatutos, em 1855. Por eles, desde seu estabelecimento a Tranquilidade estaria apta "a segurar em todo o Império do Brasil contra a mortandade de escravos"152. Porém, a ausência de debates em torno deste negócio parece ter gerado um efeito contrário àquele que abalou o entendimento sobre o seguro de vida de pessoa livre. Nesse sentido, o fato de no século XIX a doutrina jurídica brasileira não ter se

${ }^{151}$ Cf. LISBOA, José da Silva, Visconde de Cairu, op. cit., p. 205. O comentário de Cândido Mendes de Almeida compõe a nota de número 4.

${ }^{152}$ Cf. Decreto ${ }^{\circ} 1.669$, de 7 de novembro de 1855 , artigo $1^{\circ}$ dos Estatutos em anexo. 
dedicado aos seguros que se faziam para garantir a vida dos escravos parece ser um indicativo do verdadeiro status atribuído pela sociedade a este negócio: seria algo natural, corriqueiro, e que não levantaria muitos questionamentos acerca de sua possibilidade ou validade $^{153}$.

O Código Comercial de junho de 1850, ao mesmo tempo em que proibira a contratação de seguros sobre a vida de pessoa livre, de igual modo proibira que se realizassem os seguros sobre a vida dos escravos, porém quando sujeita a um risco muito particular. Embora nenhum de seus dispositivos o desautorizasse expressamente, a combinação de pelo menos um deles com as demais normas que já compunham a legislação do Brasil, ou que a ela ainda seriam agregadas num futuro não muito distante, punha à baixo qualquer possibilidade de se contratar os seguros sobre as vidas dos escravos quando expostas aos riscos do tráfico negreiro transatlântico. De fato, o Código prescrevia que seria "proibido o seguro (...) Sobre coisas, cujo comércio não seja lícito pelas Leis do Império" (artigo 686, 1), e a importação de escravos já caíra na ilegalidade havia cerca de vinte anos antes de sua promulgação, com a aprovação da Lei de 7 de novembro de $1831^{154}$. Além do mais, alguns meses depois, em setembro de 1850, a Lei Eusébio de Queiroz reafirmaria a proibição do tráfico, então sob uma fiscalização mais intensa, e, por conseguinte, consolidaria o impedimento de se segurar as vidas dos cativos trazidos por aqueles empreendimentos marítimos remanescentes, que teimavam em se arriscar na navegação de costa a costa do Atlântico.

Os seguros de vida de escravos que a companhia Tranquilidade fora autorizada a negociar na praça comercial do Rio de Janeiro, no entanto, não sofreria qualquer impedimento legal procedente do Código Comercial, ou de qualquer outra norma vigente no Brasil. O negócio seria distinto, portanto, daquele que fora proibido quando se expunha a vida dos cativos aos riscos do transporte marítimo. Se o tráfico negreiro estava desautorizado pelas leis do Império, qualquer negócio que lhe socorresse deveria ser desestimulado e, assim, acompanhá-lo na sua decadência. $O$ que teria feito a

\footnotetext{
${ }^{153}$ José da Silva Costa chega a elencar os bens terrestres seguráveis: a) Vida; b) Bens móveis, semoventes e imóveis; c) Direito de usufruto, uso e habitação; d) Responsabilidade do locatário; e) Solvabilidade do devedor; f) Reparação dos danos provenientes de desastres; g) Substituição do recrutado para o serviço militar. Em seguida, expõe as modalidades de seguro de vida, mas em momento algum afirma se, sobre a vida do escravo, contrata-se um seguro de vida ou um seguro sobre algum bem do senhor. Cf. COSTA, José da Silva, op. cit., p. 187-194.

${ }^{154} \mathrm{O}$ texto do primeiro artigo da Lei de 1831 dizia que "Todos os escravos, que entrarem no território ou portos do Brasil, vindos de fora, ficam livres". A seguir o mesmo dispositivo passa a relacionar algumas exceções e, posteriormente, outros dão conta de estabelecer as penas e as pessoas a quem deveriam ser aplicadas caso praticassem a importação.
} 
Tranquilidade, então, seria contratar com os proprietários interessados nos préstimos de seus serviços o pagamento, sob a forma de indenização, de certa quantia previamente combinada, e que daria conta de ressarci-los dos prejuízos causados aos seus patrimônios, advindos da morte de qualquer um de seus escravos segurados. Estava a se falar em seguros terrestres e, assim como ela, o mercado estabelecido na província haveria de conhecer outras tantas companhias empenhadas nesse ramo dos seguros de vida de escravos que, ao invés de socorrer o tráfico, acabaria por refletir outra preocupação fundamental daquela sociedade oitocentista encravada na província do Rio de Janeiro: a de se perpetuar escravista.

\section{As Companhias de seguros de vida de escravos, desde meados do século XIX.}

À medida de seus acontecimentos, os anos compreendidos entre as décadas de 1840 e 1850 foram modificando os contornos já característicos de uma sociedade que havia muito vinha convivendo com a escravidão. Fora por essa época que a senhora dos mares se tornara cada vez mais intolerante à teimosia dos traficantes brasileiros que insistiam na perpetuação do tráfico transatlântico e, sobretudo durante os cinco anos anteriores à promulgação da Lei Eusébio de Queiroz, recrudescera a perseguição que desde os anos de 1830 impingia às embarcações destinadas ao tráfico negreiro ilegal, mesmo se para isso tivesse de adentrar as águas e os portos nacionais. Quando em setembro de 1850, diante de tamanha pressão, o governo imperial manifestara claramente sua decisão de aderir à causa britânica - até mesmo como forma de resguardar o direito de uma nação independente exercer a soberania sobre a totalidade de seu próprio território - e colocar ele próprio seus navios de guerra à caça dos negreiros que porventura desembarcassem nas costas brasileiras, não havia mais como duvidar que a importação de novos cativos africanos para o país estaria, de fato, com seus dias contados.

O tráfico transatlântico poderia ser tomado como um negócio capitalista, digamos, no qual os investidores empregavam seu capital e ficavam à espera dos lucros advindos com a venda dos cativos trazidos da África. Contudo, de igual modo fora considerado um negócio estruturante da sociedade brasileira oitocentista, pois significava a principal fonte de alimentação de um sistema que carecia, a todo momento, da oferta de mão de obra escrava para ser empregada nas lavouras. A abolição do tráfico negreiro, portanto, trouxe 
consigo um inevitável rearranjo do mercado carioca, e de igual modo da própria sociedade - caso seja considerado seu impacto sobre os acontecimentos dos quarenta anos seguintes -, pois, além de ter promovido a transferência do capital dantes empregado nesta atividade negreira para outros setores do comércio (como bancos, ferrovias, ou companhias mercantis de diversas finalidades), fez extinguir completamente o principal meio de reprodução daquela força de trabalho tão indispensável à agricultura, especialmente às plantações de café da região sudeste do Brasil.

Aliás, antes mesmo de 1850 os cafeicultores pareciam estar cônscios de que num futuro nem tão distante vivenciariam tempos de profundas mudanças na maneira como deveriam administrar suas produções ${ }^{155}$, tempos em que a busca por soluções que dessem conta de contornar o problema do abastecimento de mão de obra escrava a ser empregada no trabalho das fazendas estivera na ordem do dia. Não tardou muito até que formas alternativas de aquisição de escravos começassem a ser retomadas a níveis cada vez maiores. As regiões cafeeiras da província do Rio de Janeiro e do Vale do Paraíba paulista, produtoras da principal mercadoria na pauta das exportações brasileiras de então, por exemplo, foram as que mais receberam os escravos comprados de centros urbanos da própria província; ou comprados das províncias do Sul e do Nordeste, importantes vendedoras de mão de obra durante o período em que vigorou o tráfico interno, intensificado logo da abolição do tráfico transatlântico e que se prolongaria até o começo dá década de $1880^{156}$. E o tráfico interprovincial, como é sabido, quando praticado pela costa e durante a época em que foram frequentes as investidas britânicas em águas brasileiras, não estaria isento dos mesmos riscos que acometiam as embarcações negreiras mobilizadas para o tráfico transatlântico ilegal.

Tal fora o que ocorrera com o navio brasileiro de cabotagem denominado Piratinim quando, em 1851, rumava primeiro à Bahia, e depois à região sudeste, com o objetivo de

${ }^{155}$ O Manual do Agricultor Brasileiro, escrito por Carlos Augusto Taunay em 1837, e a Memória sobre a Fundação de uma Fazenda na Província do Rio de Janeiro, de autoria de Francisco Peixoto de Lacerda Werneck, de 1847 , foram os principais manuais de fazendeiro publicados durante a primeira metade do século XIX. Ambos pregavam certa racionalidade na forma como os fazendeiros deveriam administrar suas terras e, às vésperas da abolição do tráfico negreiro, defendiam a necessidade de mudança da forma de tratamento dispensada às propriedades escravas. Como a futura escassez de mão de obra já estivera anunciada, os fazendeiros deveriam estimular a produção dos cativos, seja "através da constituição de uniões estáveis ou pela melhoria do tratamento concedido às pretas grávidas e aos recém-nascidos, no incremento do sustento material dos negros - senzalas salubres, vestimentas sempre limpas e secas, três refeições diárias, cuidados nas enfermidades -, e na concessão de recompensas aos trabalhos diligentes (...)”, cf. MARQUESE, Rafael de Bivar, A Administração do trabalho escravos nos manuais de fazendeiro do Brasil Império, 18301847, p. 107-108.

${ }^{156}$ Cf. PENA, Eduardo Spiller, Burlas à lei e revolta escrava no tráfico interno do Brasil Meridional, século XIX, p. 164. 
descarregar mais de uma centena de escravos. Algum tempo antes de sua captura o navio negreiro Sylphide obtivera um relativo sucesso ao desembarcar mais de quatrocentos cativos na província de Alagoas, todos frutos do tráfico ilegal. Quando se espalhou a notícia de que muito provavelmente alguns deles iriam ser transportados para outras localidades do país, o navio britânico Sharpshooter deteve o Piratinim no dia 22 de julho e, por mais que os cativos ali contidos possuíssem passaportes das autoridades baianas, o Tenente Bailey, após transferi-los ao navio britânico Crescent, afundou a embarcação brasileira sem temer as repercussões do caso ${ }^{157}$. Os meios alternativos pelos quais os escravos puderam ser adquiridos, portanto, de igual modo fizeram emergir os riscos inerentes quando de seus empreendimentos.

Além disso, a abolição do tráfico fez com que os senhores começassem a enxergar a propriedade escrava com outros olhos. Durante todo esse processo ao fim do qual fora interrompida a importação de africanos para o país, os preços atribuídos aos escravos disponíveis num antigo mercado passariam a dançar conforme a nova conjuntura. A oferta de mão de obra já não era em demasia e, ao fim da década de 1850, a compra de um escravo poderia custar o dobro, ou o triplo, do que fora seu valor nos tempos em que o comércio transatlântico gozava de certa tranquilidade no oceano. A perda de um escravo, portanto, seja pela fuga ou para a morte, muito provavelmente provocaria um prejuízo maior ao patrimônio do proprietário do que lhe ocorreria se pudesse ser facilmente reposta pela compra dentre os cativos recém desembarcados da costa africana.

Novos tempos, outras necessidades, novos riscos, e os negociantes estabelecidos na província do Rio de Janeiro logo começaram a se articular para, sem perder os lucros de vista, aproveitar-se das oportunidades que o mercado lhes oferecia. Já em 1846 o Almanak Laemmert anunciara uma seguradora cuja finalidade seria a de garantir os prejuízos que as eventuais mortes dos escravos pudessem provocar aos patrimônios de seus proprietários. Como membros da Diretoria, Pedro de Araújo Lima, então Visconde de Olinda ${ }^{158}$;

\footnotetext{
${ }^{157}$ Cf. BETHELL, Leslie, A Abolição do tráfico de escravos no Brasil, p. 335-336; 355. A destruição do navio Piratinim gerou uma manifestação agressiva por parte de Paulino José Soares de Sousa (Visconde de Uruguai), então Ministro dos Negócios Estrangeiros do Império, mediante a qual acusara os britânicos de terem já se esquecido de perseguir o tráfico ilegal e estarem investindo, de fato, contra a própria estrutura da sociedade brasileira, cf. PARRON, Tâmis, A política da escravidão no Império do Brasil, 1826-1865, p. 245.

${ }^{158}$ Pedro de Araújo Lima (Visconde em 1841; e em 1854, Marquês de Olinda) nasceu em 1793, no dia 22 de dezembro, em Pernambuco; e morreu em 1870, no Rio de Janeiro, no dia 7 de junho. Formado em Cânones em Coimbra, foi magistrado, ministro, e também Deputado às Cortes de Lisboa, à Constituinte de 1823, e à Assembleia Geral por diversas legislaturas. Foi nomeado Senador em setembro de 1837, mesmo ano em que viria a ser o Regente do Império, cargo que desocuparia com a sobrevinda do Golpe da Maioridade, em 1840. Cf. BLAKE, Augusto Victorino Alves Sacramento, op. cit., vol. 7, p. 16-17.
} 
Cândido José de Araújo Vianna ${ }^{159}$; e Eusébio de Queiroz ${ }^{160}$; todos eles foram os Fiscais da companhia que teria o Dr. Benoit Mure ${ }^{161}$ como seu Diretor Gerente e João Vicente Martins ${ }^{162}$ como um de seus administradores: a Companhia de Seguros sobre a Vida dos Escravos Prosperidade (19) ${ }^{163}$, apontada pelas fontes consultadas como a precursora na

${ }^{159}$ Cândido José de Araújo Vianna (Marquês de Sapucahy) nasceu em Sabará, Minas Gerais, no dia 15 de setembro de 1793. Cursou Direito na Universidade de Coimbra e tão logo se formou foi nomeado Juiz de Fora de sua comarca natal. Representando a mesma província em que nasceu, foi Deputado na Constituinte de 1823, e também nas quatro legislaturas seguintes. Chegou a ser Presidente das províncias de Alagoas e do Maranhão, e também Conselheiro de Estado. Foi eleito Senador do Império em 1839, e nomeado Ministro dos Negócios da Fazenda, da Justiça (ministro interino, de 14 de dezembro de 1832 a junho de 1834), e do Império (1841-1843). Faleceu no dia 23 de janeiro de 1875, no Rio de Janeiro. Cf. BLAKE, Augusto Victorino Alves Sacramento, op. cit., vol. 2, p. 30-31.

${ }^{160}$ Eusébio de Queiroz Coutinho Mattoso da Câmara nasceu em São Paulo de Luanda, aos 27 de dezembro de 1812. Formou-se em Direito pela Faculdade de Olinda e em 1833 foi nomeado Juiz de Fora. No ano seguinte, foi nomeado Chefe de Polícia da Corte e por aí permaneceria por cerca de dez anos (1834-1844), período dentro do qual também fora nomeado desembargador da Relação do Rio de Janeiro. Chegou a ser eleito Deputado provincial e geral, e também Senador do Império. Quando a armada britânica havia intensificado suas investidas contra os negreiros brasileiros, em águas nacionais, ocupava o Ministério da Justiça (1848-1852). Diante de tamanha pressão internacional pelo fim do tráfico transatlântico de escravos, foi o propositor de um projeto de lei que, após ter tramitado pela Assembleia Geral e pelo Senado, tornou-se lei no dia 4 de setembro de 1850, a Lei Eusébio de Queiroz. Quando de seu falecimento no Rio de Janeiro, no dia 7 de maio de 1868, era Conselheiro de Estado. Cf. BLAKE, Augusto Victorino Alves Sacramento, op. cit., vol. 2, p. 308-309.

${ }^{161}$ Dr. Benoit Jules Mure, também conhecido como Dr. Bento Mure, nasceu em Lyon, na França, no dia 4 de maio de 1809, e chegou ao Brasil a bordo da barca francesa Eole, no fim do ano de 1840 (21 de novembro). Começou a propagar pelo mundo os benefícios que a medicina homeopática poderia trazer à saúde dos homens, ao que parece, por volta de 1833, quando foi curado de tuberculose (então com 24 anos de idade). Divulgou esta terapêutica em Palermo (Itália), em Paris (França), na Sicília (Itália), em Malta (Itália), e de igual modo é considerado um dos introdutores da homeopatia no Brasil. Acabou por se tornar um dos maiores propagandistas da doutrina no país e, no dia 10 de dezembro de 1843 , fundou, juntamente com Vicente José Lisboa, o Instituto Homeopático do Brasil. Aí seria empossado Presidente, enquanto José Lisboa seria investido do cargo de $1^{\circ}$ Secretário. Seu vínculo com a instituição ainda persistiria mesmo depois de seu retorno à Europa, no dia 13 de abril de 1848, como passageiro da barca francesa Girande. Quando decidira não mais voltar ao Brasil, fora eleito Presidente Perpétuo do Instituto na sessão de 26 de outubro de 1851, presidida por João Vicente Martins (então $1^{\circ}$ Secretário, mas exercendo a presidência interina). Faleceu no dia 4 de março de 1858, no Cairo (Egito), para onde havia partido também com a missão de divulgar a homeopatia, porém não antes de ter fundado o Instituto Homeopático em Gênova (Itália), em 1854. Morreu aos 49 anos de idade. Cf. GALHARDO, José Emydio Rodrigues, História da homeopatia no Brasil, p. 277; 279; 325; 511; 652; 688-692; Dicionário histórico-biográfico das Ciências da Saúde no Brasil (1832-1930), ver entrada "Instituto Homeopático do Brasil".

${ }_{162}$ João Vicente Martins nasceu em Lisboa, no dia 16 de setembro de 1808 . Tão logo foi diplomado pela Escola Médico Cirúrgica de Lisboa, em 1836, partiu em viagem ao Rio de Janeiro, e ali chegou no dia 30 de janeiro de 1837. Foi convidado a exercer a medicina no Hospital dos Lázaros no dia 12 de março do ano seguinte (1838), e, no início de 1839, a ser o responsável pela clínica da Santa Casa de Misericórdia; mas não permaneceria por muito tempo em qualquer um dos dois empregos (abandou-os logo no primeiro semestre de 1840). Dedicou-se a fundo em conhecer a homeopatia, e foi um dos maiores propagandistas desta terapêutica no país. Foi um dos sócio-fundadores do Instituto Homeopático do Brasil, em dezembro de 1843, e juntamente com o Dr. Benoit Mure participou de diversos e acirrados debates contra os defensores da medicina alopática. Morreu no dia 7 de julho de 1854, aos 45 anos de idade, um ano depois de ter sido naturalizado cidadão brasileiro (11 de junho de 1853). Cf. GALHARDO, José Emydio Rodrigues, op. cit., p. $276 ; 308 ; 674 ; 677-678$.

${ }_{163}$ Ao que tudo indica, talvez a seguradora Prosperidade possa ser compreendida como um instrumento, digamos, que serviu aos propósitos dos propagadores da terapêutica homeopática no Brasil durante os meados do século XIX. De fato, a companhia fora estabelecida numa época em que muito se fazia pela divulgação da doutrina. Em 1845 (21 de janeiro) deu-se a aprovação dos Estatutos da Escola Homeopática 
contratação sobre estes riscos. Contudo, não demoraria muito até que a situação da praça comercial do Rio de Janeiro comportasse o funcionamento de mais seguradoras interessadas em atuar nesse ramo do mercado.

Incluindo a Prosperidade, foram computadas 11 companhias, no total. Todas elas brasileiras e sediadas na província do Rio de Janeiro, e que muito provavelmente enxergariam a Corte e seus arredores como os mercados mais promissores ao sucesso de seus negócios. A Tabela 3 dá conta de apresentá-las, de modo que se permita extrair mais informações a respeito de cada uma delas. É o caso de se conhecer o tipo societário sob os quais estariam organizadas. De todas, pelo menos 7 eram sociedades anônimas, e outras 3 foram se constituindo pela associação mútua de proprietários de escravos. A respeito da Companhia de Seguros sobre a Vida dos Escravos Prosperidade (19), as fontes consultadas não informaram se seus sócios seriam acionistas em busca de lucro, simplesmente, ou se seriam associados, que se juntariam apenas para garantirem uns aos outros o valor dos escravos perdidos. De todo modo, ela e outras quatro companhias

do Brasil, dirigida pelo Dr. Benoit Mure, e instalada na rua São José $\mathrm{n}^{\circ}$ 59, mesmo endereço em que funcionaria a Botica Homeopática Central. Em fevereiro de 1846, estabeleceu-se a Casa de Saúde Homeopática na chácara do Marechal Sampaio, no Morro do Castelo (em frente à antiga Sé). Poucos meses depois, no dia 29 de junho de 1846, fundou-se a Sociedade Hahnemanniana, entidade científica que logo fez circular a revista $O$ Hahnemannista, meio que auxiliou a defesa da homeopatia no país. Escapando à Corte, não tardou muito até que, em outubro de 1847, fora fundada a Sociedade Homeopática Baiana, e, em 1849, a Sociedade Homeopática Maranhense. Além do estabelecimento de instituições, os defensores da terapêutica, principalmente o Dr. Benoit Mure e João Vicente Martins, participariam constantemente dos debates levados à imprensa coeva contra os adeptos da medicina alopática (Jornal do Commercio, por exemplo); e também publicariam obras cujo objetivo, dentre outros, seria o de esclarecer os cidadãos a respeito do novo método de cura: em 1845, por exemplo, o Dr. Benoit Mure, em colaboração com João Vicente Martins, soltou a primeira edição da Prática Elementar da Homeopatia, obra que ensinava os leigos em medicina a tratarem de si próprios mediante a observância às prescrições homeopáticas; e, em 1846, Vicente Martins traduziu a obra Organon de [Samuel Christian Friedrich] Hahneimann, ou exposição das doutrinas homeopáticas, e publicou as Notícias Elementares da Homeopatia, ou Manual do fazendeiro, do capitão de navio, e do pai de família: contendo a ação dos vinte e quatro medicamentos homeopáticos. Em meio a esse intenso movimento, a seguradora Prosperidade, "companhia de seguros de vida de escravos tratados homeopaticamente", segundo as palavras de José Emydio Rodrigues Galhardo, fora estabelecida em 1845, na já conhecida rua São José $n^{\circ} 59$. E, ao que parece, as pessoas que compuseram seus quadros diretivo e administrativo estiveram estritamente vinculadas à causa homeopática no Brasil. De fato, além do Dr. Benoit Mure (Diretor Gerente) e de João Vicente Martins (administrador), conhecidos propagadores da doutrina no país, também o farmacêutico José Victorino Ventura Pinheiro (administrador) fora adepto da homeopatia, assim como o fora Egídio Talloni (administrador), este, sócio-fundador do Instituto Homeopático do Brasil criado em dezembro de 1843. E se os nomes dos Fiscais da companhia causam surpresa à primeira vista, justamente por serem tão logo vinculados à alta burocracia estatal, ao menos dois deles - Pedro de Araújo Lima (Visconde de Olinda) e Cândido José de Araújo Vianna (Visconde de Sapucahy) - foram eleitos membros da Diretoria do Instituto Homeopático do Brasil na sessão de 10 de janeiro de 1846. Diante de tudo isso, e sem nos esquecermos dos objetivos capitalistas de tal empreendimento, seria uma hipótese razoável considerar a incorporação da companhia de seguros Prosperidade como mais um artifício dentre os quais lançaram mão aqueles que lutaram pela divulgação e pela prática da medicina homeopática no país. Mas, para testá-la, necessitaríamos de consultar outras fontes, que informassem algo além do que pode ser apreendido pela chamada constante das páginas 205-206 do Almanak Laemmert publicado em 1846. Cf. GALHARDO, José Emydio Rodrigues, op. cit., p. 308, 313, 322, 325; Dicionário histórico-biográfico das Ciências da Saúde no Brasil (1832-1930), ver entrada "Instituto Homeopático do Brasil". 
estariam dedicadas exclusivamente a este negócio; as demais, se não seguraram simultaneamente os riscos provenientes da navegação marítima ou fluvial, estiveram dispostas à garantia, pelo menos, de outros riscos terrestres.

Se comparadas ao total das companhias que chegaram a segurar os riscos terrestres no Rio de Janeiro durante quase todo o século XIX, percebe-se que, conforme demonstra o Gráfico 12, a seguir, o número das seguradoras de vida de escravos que ano a ano estiveram em funcionamento na província não acompanhou a tendência sempre crescente da concentração do mercado carioca. Por outro lado, se a comparação recair somente sobre o total de companhias de seguros nacionais, que de igual modo chegaram a negociar sobre os riscos terrestres, nota-se certa harmonia entre alguns movimentos reveladores da queda e da intensificação da presença de todas elas naquela praça comercial, pelo menos ela é notória para os períodos correspondentes às décadas de 1850, 1870 e 1880. O Gráfico 13, portanto, dá conta de representar essas linhas, por onde se depreende que as mesmas oportunidades oferecidas pelo mercado puderam ser aproveitadas tanto pelas companhias de seguros terrestres, nacionais, como também pelas seguradoras de vida de escravos.

Com exceção da Prosperidade, cuja única informação a respeito de sua existência foi noticiada pelo Almanak Laemmert publicado no ano de 1846, todas as outras companhias de seguros de vida de escravos estabelecidas na província do Rio de Janeiro funcionaram somente durante a segunda metade do século XIX. As informações provenientes das fontes consultadas revelam que a maioria dessas seguradoras chegou a oferecer seus serviços por um breve período de tempo, um ano, ou pouco mais que isso. Nesse sentido, mesmo se desconsiderarmos os casos da Companhia de Seguros UtilPrevidência (52), cuja notícia de sua existência provém de uma única fonte, o Decreto $\mathrm{n}^{\circ}$ 2.574 de 14 de abril de 1860; e da Equitativa Brasileira (107), conhecida somente pelo Decreto $\mathrm{n}^{\circ} 6.512$ de 13 de março de 1877; ainda seriam evidentes as situações vivenciadas pela Companhia de Seguros União Fluminense (71), que funcionou por apenas um ano (1870-1871), assim como a Companhia Garantidora de Vidas (98) (1875-1876); e também da Companhia de Seguros Previdência (30) que, ao que tudo indica, teria funcionado por cerca de um lustro, durante a década de 1850. 
Tabela 3: Companhias seguradoras de vida de escravos em autorizadas a funcionar na Província do Rio de Janeiro (1808-1889)

\begin{tabular}{|c|c|c|c|c|c|c|}
\hline & & & & \multicolumn{2}{|c|}{ Funcionamento } & \\
\hline Série & Companhia & Sede & Tipo Societário & $1^{\mathrm{a}}$ data & Data final & Riscos segurados \\
\hline $1(19)$ & $\begin{array}{l}\text { Companhia de Seguros sobre a } \\
\text { Vida dos Escravos } \\
\text { Prosperidade }\end{array}$ & Rio de Janeiro & - & 1845 & 1845 & Terrestres (vida de escravos) \\
\hline $2(30)$ & $\begin{array}{l}\text { Companhia de Seguros } \\
\text { Previdência }\end{array}$ & Rio de Janeiro & Sociedade Anônima & 05.08 .1854 & 1859 & Terrestres (vida de escravos) \\
\hline $3(39)$ & $\begin{array}{l}\text { Companhia de Seguros } \\
\text { Tranquilidade }\end{array}$ & Rio de Janeiro & Sociedade Anônima & 07.11 .1855 & 06.02 .1858 & $\begin{array}{l}\text { Terrestres (vida de escravos/vida de } \\
\text { pessoas livres) }\end{array}$ \\
\hline $4(42)$ & $\begin{array}{l}\text { Companhia Mútua de Seguros } \\
\text { de vida de escravos }\end{array}$ & Rio de Janeiro & Associação & 1857 & 1866 & Terrestres (vida de escravos) \\
\hline $5(44)$ & $\begin{array}{l}\text { Companhia de Seguros } \\
\text { Marítimos e Terrestres Feliz } \\
\text { Lembrança/ Companhia Geral } \\
\text { de Seguros União }\end{array}$ & Rio de Janeiro & Sociedade Anônima & 16.01 .1858 & 1873 & $\begin{array}{l}\text { Marítimos/ Terrestres (vida de } \\
\text { escravos; vida de pessoas livres; } \\
\text { alugueis) }\end{array}$ \\
\hline $6(52)$ & $\begin{array}{l}\text { Companhia de Seguros Util- } \\
\text { Previdência }\end{array}$ & Rio de Janeiro & Sociedade Anônima & 14.04 .1860 & 14.04 .1860 & Terrestres (vida de escravos) \\
\hline $7(71)$ & $\begin{array}{l}\text { Companhia de Seguros União } \\
\text { Fluminense }\end{array}$ & Rio de Janeiro & Sociedade Anônima & 28.04 .1870 & 1871 & Terrestres (vida de escravos) \\
\hline $8(77)$ & $\begin{array}{l}\text { Companhia de Seguros } \\
\text { Perseverança }\end{array}$ & $\begin{array}{l}\text { Campos dos } \\
\text { Goytacazes, Rio de } \\
\text { Janeiro }\end{array}$ & Sociedade Anônima & 23.11 .1871 & 1888 & $\begin{array}{l}\text { Marítimos/ Terrestres (incêndios; vida } \\
\text { de escravos) }\end{array}$ \\
\hline $9(98)$ & $\begin{array}{l}\text { Companhia Garantidora de } \\
\text { Vidas }\end{array}$ & Rio de Janeiro & Sociedade Anônima & 06.11 .1875 & 1876 & $\begin{array}{l}\text { Terrestres (vida de pessoas livres e } \\
\text { escravas) }\end{array}$ \\
\hline $10(99)$ & $\begin{array}{l}\text { Companhia de Seguros Mútuos } \\
\text { União }\end{array}$ & Rio de Janeiro & Associação & 14.12 .1875 & 1883 & $\begin{array}{l}\text { Terrestres (vida de escravos; prejuízos } \\
\text { de emancipações forçadas) }\end{array}$ \\
\hline $11(107)$ & A Equitativa Brasileira & Rio de Janeiro & Associação & 13.03 .1877 & 13.03 .1877 & $\begin{array}{l}\text { Terrestres (vida de pessoas livre e } \\
\text { escravas) }\end{array}$ \\
\hline
\end{tabular}

Fonte: Quadro Companhias de Seguros em funcionamento na Província do Rio de Janeiro (1808-1889), cf. Anexo 2; Coleção das Leis do Império do Brasil (1808-1889). 
Gráfico 12: Companhias seguradoras de vida de escravos comparadas ao total das Companhias seguradoras de riscos terrestres, em funcionamento na Província do Rio de Janeiro (1808-1888)

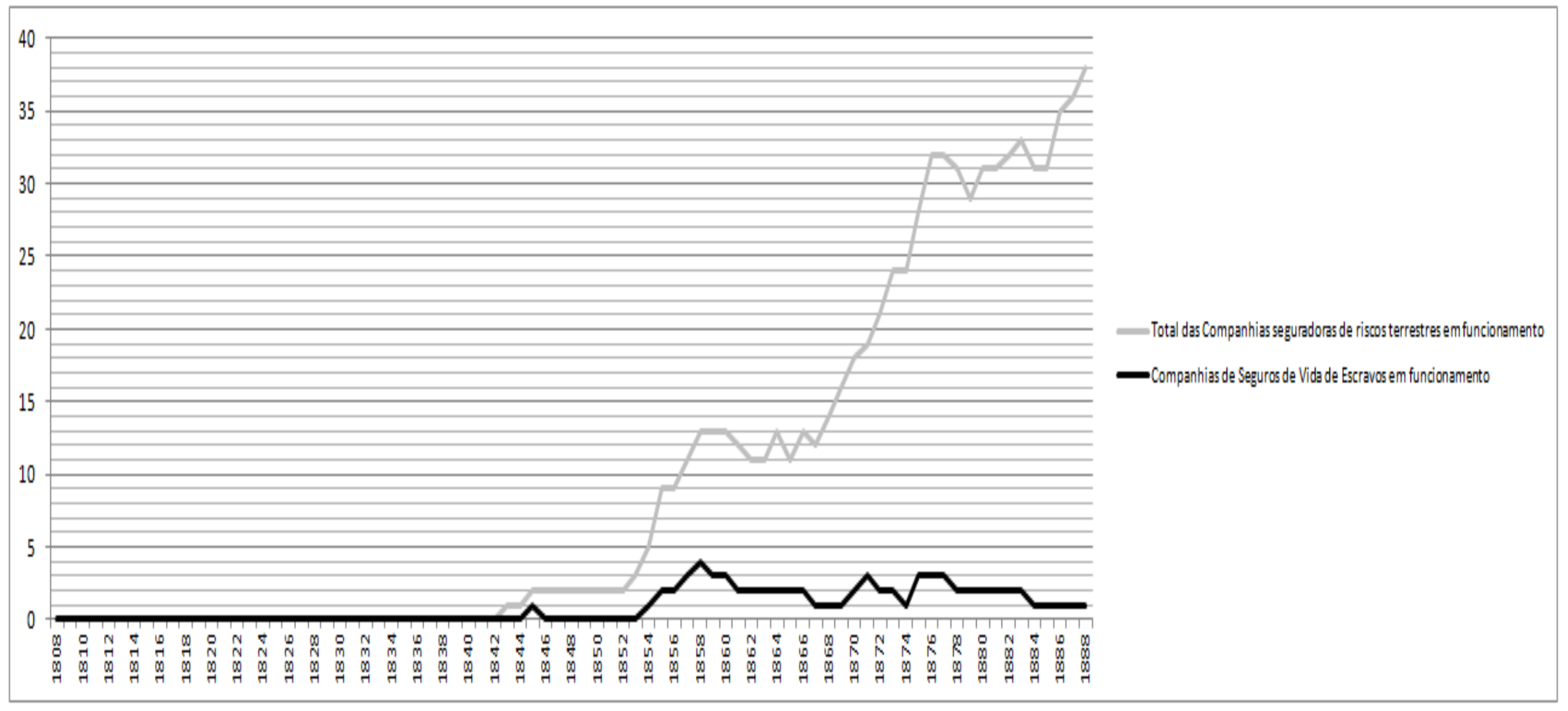

Fonte: Quadro Companhias de Seguros em funcionamento na Província do Rio de Janeiro (1808-1888), cf. Anexo 2. 
Gráfico 13: Companhias seguradoras de vida de escravos comparadas ao total das Companhias seguradoras nacionais de riscos terrestres, em funcionamento na Província do Rio de Janeiro (1808-1888)

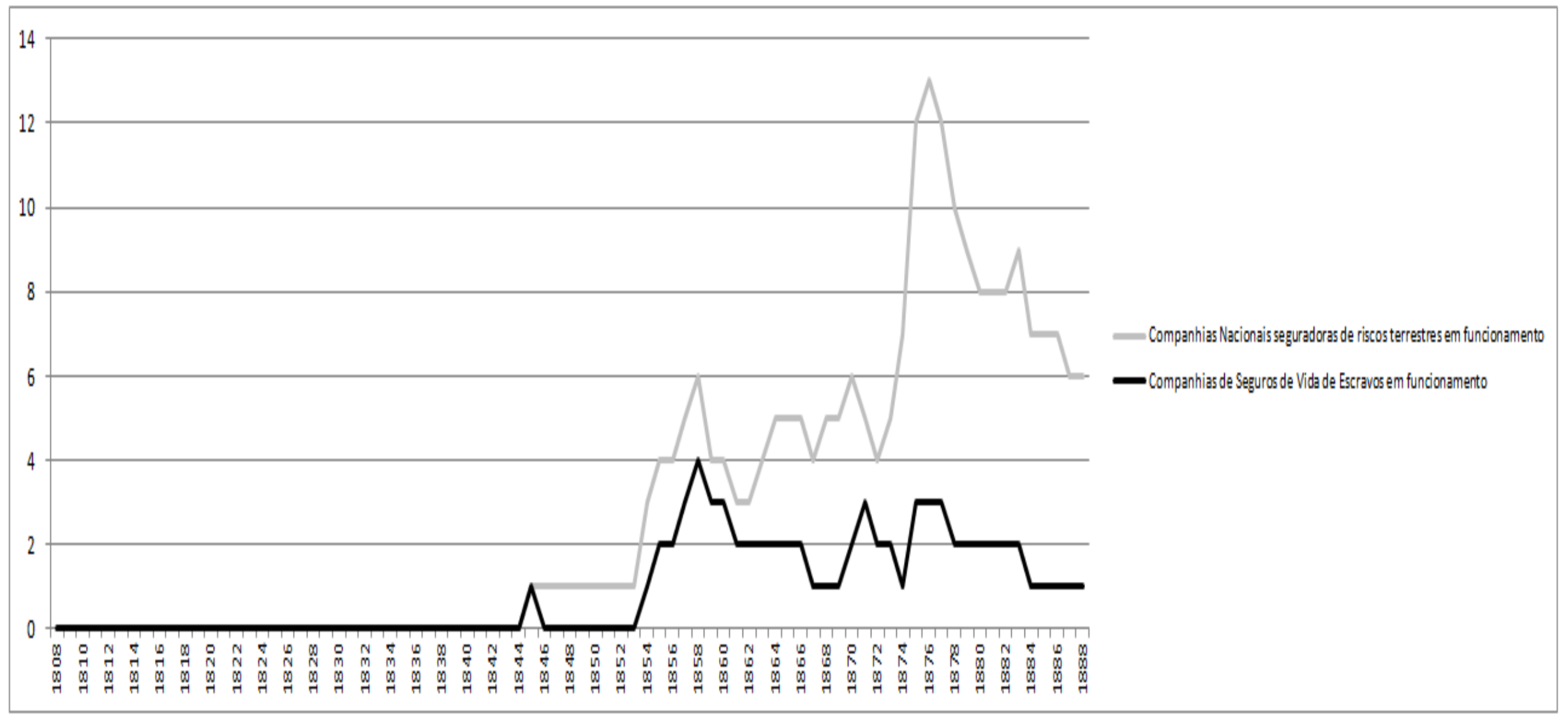

Fonte: Quadro Companhias de Seguros em funcionamento na Província do Rio de Janeiro (1808-1888), cf. Anexo 2. 
Por outro lado, a Companhia Mútua de Seguros de vida de escravos (42), a Companhia de Seguros Marítimos e Terrestres Feliz Lembrança (44) - posteriormente denominada Companhia Geral de Seguros União -, a Companhia de Seguros Mútuos União (99), e a Companhia de Seguros Perseverança (77), todas elas chegaram a funcionar por cerca de dez anos, ou mais, como fora o caso desta última, a Perseverança, que insistiria em atuar neste negócio mesmo quando, paulatinamente, o processo abolicionista foi ganhando força a partir da década de 1870, e o fim da escravidão já ficara cada vez mais evidente aos olhos dos coevos; sua duração alcançaria as vésperas da abolição da escravatura, em 1888.

Assim como ocorrera quando comparadas ao total das companhias que chegaram a atuar no ramo dos seguros terrestres, as curvas que denunciaram a maior ou menor concentração dos seguros contratados sobre a vida dos escravos na praça comercial do Rio de Janeiro não coincidiram com as linhas correspondentes ao total de seguradoras que estiveram em funcionamento nessa mesma província. A não ser por alguns anos situados principalmente nas décadas de 1860 e 1870/1880, todos os outros acabaram por revelar o constante aumento do número de companhias em atividade nesse mercado. O Gráfico 14, de igual modo, vem para denunciar que, pelo visto, o período que concentrou o funcionamento do maior número de companhias seguradoras de vida de escravos ficou restrito aos meados da década de 1850 até o princípio dos anos de 1880.

$\mathrm{O}$ ano de 1858 foi o ano em que o mercado segurador estabelecido na praça comercial do Rio de Janeiro presenciou o maior número de companhias dispostas a segurar a vida dos escravos dispersos pela província. Aí estiveram em atividade 4 seguradoras dedicadas a este negócio. Por outro lado, a média de companhias em funcionamento nesta mesma década de 1850 fora equivalente à média das que estiveram em operação durante a década seguinte. Esse número conheceria um leve aumento durante o decênio 1871-1880, e diminuiria nos oito anos que se seguiram até a abolição da escravatura. Por outro lado, o movimento de ascensão e queda conhecido pelas seguradoras de vida de escravos durante os anos de 1850 parece ter acompanhado a tendência que se apresentou para todas as companhias nacionais, tanto as que se dedicaram à contratação de seguros terrestres como àquelas que de igual modo se comprometeram a indenizar as perdas provenientes dos sinistros marítimos ou fluviais. 
Gráfico 14: Companhias seguradoras de vida de escravos comparadas ao total das Companhias seguradoras em funcionamento na Província do Rio de Janeiro (1808-1888)

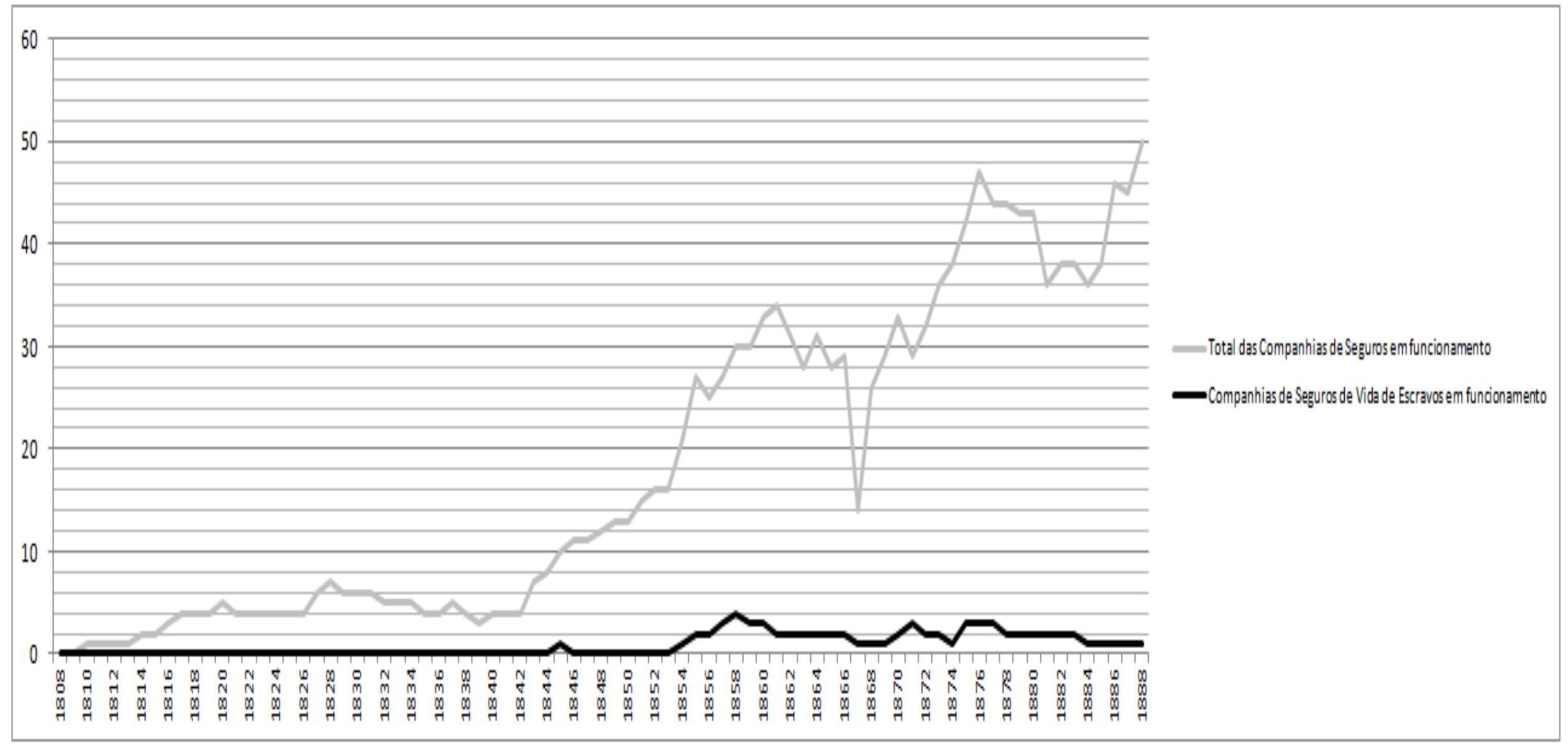

Fonte: Quadro Companhias de Seguros em funcionamento na Província do Rio de Janeiro (1808-1888), cf. Anexo 2. 
Gráfico 15: Companhias seguradoras de vida de escravos comparadas ao total das Companhias seguradoras nacionais, em funcionamento na Província do Rio de Janeiro (1808-1888)

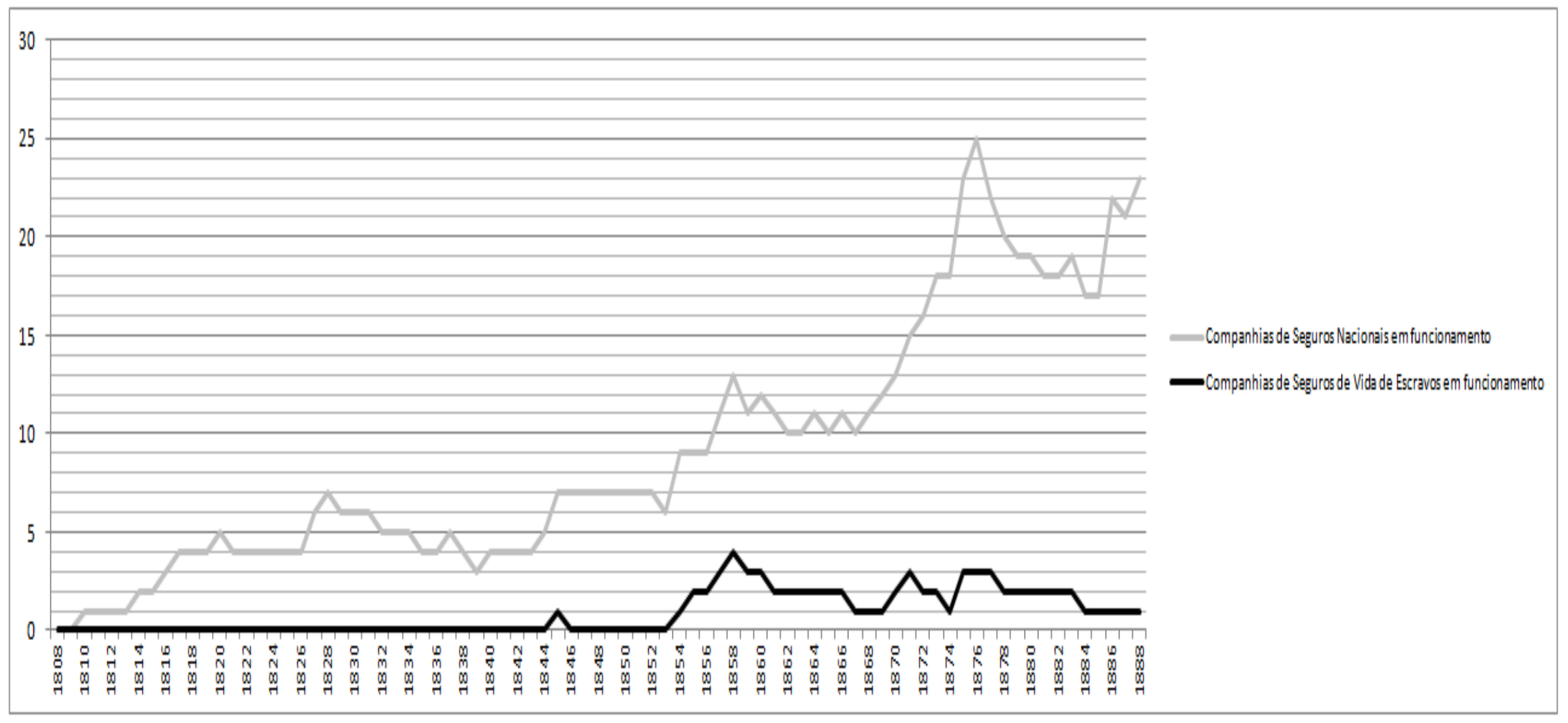

Fonte: Quadro Companhias de Seguros em funcionamento na Província do Rio de Janeiro (1808-1888), cf. Anexo 2. 
Contudo, o panorama conhecido pelo decênio de 1870 revelou-se um pouco diferente. Durante esse período, enquanto as companhias de seguros de vida de escravos estiveram distribuídas uniformemente ao longo dos anos, as seguradoras nacionais acabaram por vivenciar um segundo momento de ascensão seguida de queda, conforme demonstram os traços compartilhados pelo Gráfico 15.

Ao que parece, as conjunturas político-econômicas vivenciadas pelas décadas de 1850 e 1870 estiveram positivamente relacionadas ao incremento desse ramo do negócio segurador. Acontecimentos importantes no campo da política interna e internacional acabaram por remodelar os tradicionais contornos sobre os quais a instituição da escravidão vinha se sustentando no Brasil. Se já em meados dos anos de 1840 as incursões britânicas em águas nacionais provocaram as autoridades brasileiras à aprovação da Lei Eusébio de Queiroz (1850), em 1871 a promulgação da Lei do Ventre Livre, no dia 28 de setembro, de algum modo, dever ter sido influenciada pela libertação dos escravos nos Estados Unidos (meados de 1860) e pelo fim da Guerra contra o Paraguai (1870), que havia contado com a participação de muitos cativos nas fileiras de combate do Exército. Assim como a proibição de se escravizar o nascituro fora um golpe fatal à continuidade do cativeiro no país, da mesma forma a intensa perseguição aos negreiros que insistiam em desembarcar ilegalmente os africanos na costa brasileira, em meados do século, sugeriu a abertura de novas oportunidades de negócios num mercado que tratava diretamente com a propriedade escrava. Coincidência ou não, além dos maiores índices de funcionamento terem se concentrado durante os idos das décadas de 1850 e de 1870 , foi durante esses mesmos anos que a praça comercial do Rio de Janeiro proporcionou o surgimento de quase todas as companhias de seguros de vida de escravos. O Gráfico 16 e o Gráfico 17 permitem essa visualização. O primeiro o faz comparativamente à totalidade das seguradoras que foram se estabelecendo, ano a ano, na província e; o segundo, compara somente com a quantidade de companhias nacionais.

A Companhia de Seguros Previdência (30), a Tranquilidade (39), a Companhia Mútua de seguros de vida de escravos (42), a Companhia de Seguros Marítimos e Terrestres Feliz Lembrança (44) - que passou a se chamar Companhia Geral de Seguros União, a partir de 1870 -, a Companhia de Seguros Útil-Previdência (52); durante a década de 1850, no total cinco seguradoras de vida de escravos submeteram seus Estatutos à apreciação do governo brasileiro, e foram autorizadas a funcionar no Império. 
Gráfico 16: Companhias seguradoras de vida de escravos comparadas ao total das Companhias seguradoras, estabelecidas anualmente na Província do Rio de Janeiro (1808-1888)

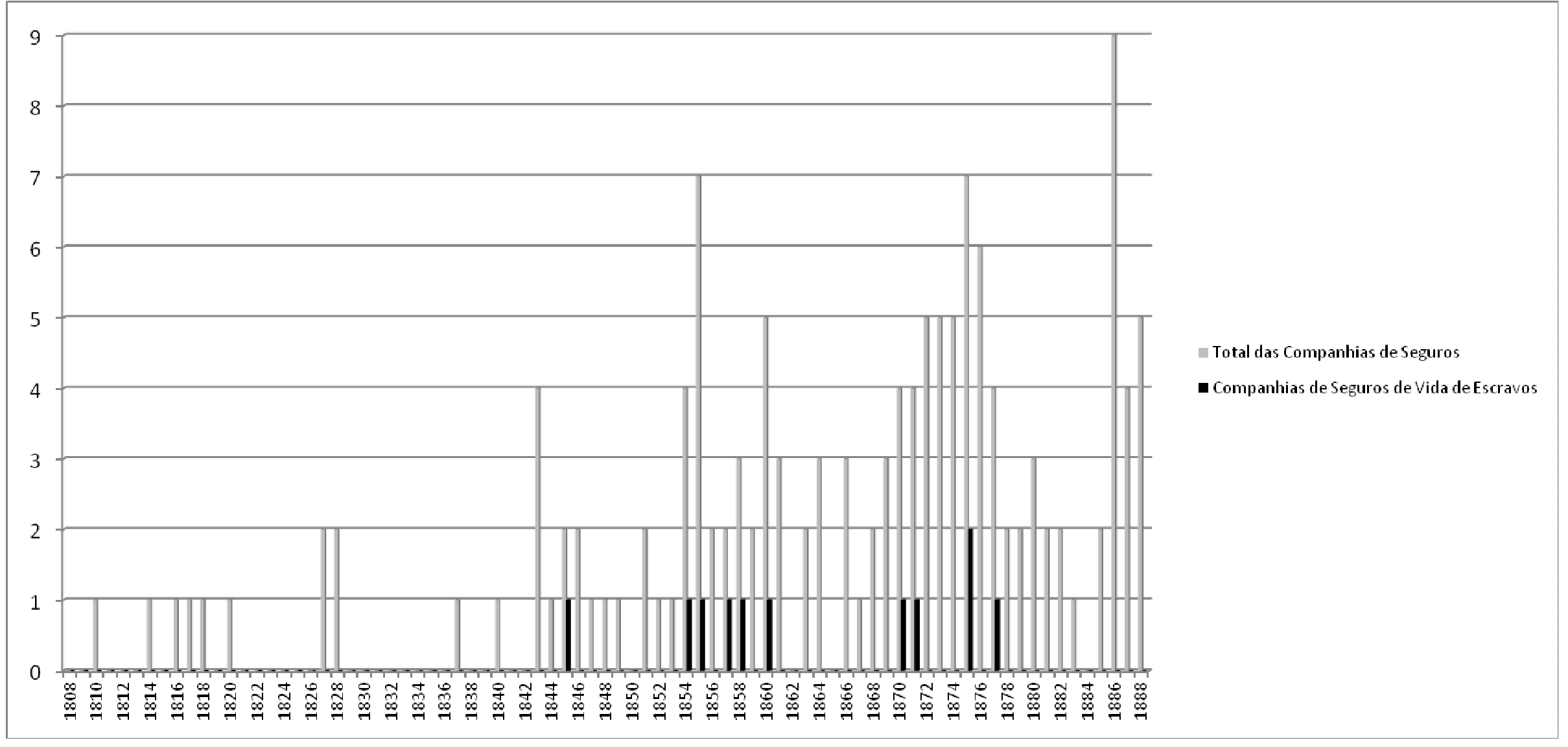

Fonte: Quadro Companhias de Seguros em funcionamento na Província do Rio de Janeiro (1808-1888), cf. Anexo 2. 
Gráfico 17: Companhias seguradoras de vida de escravos comparadas ao total de Companhias seguradoras nacionais, estabelecidas anualmente na Província do Rio de Janeiro (1808-1888)

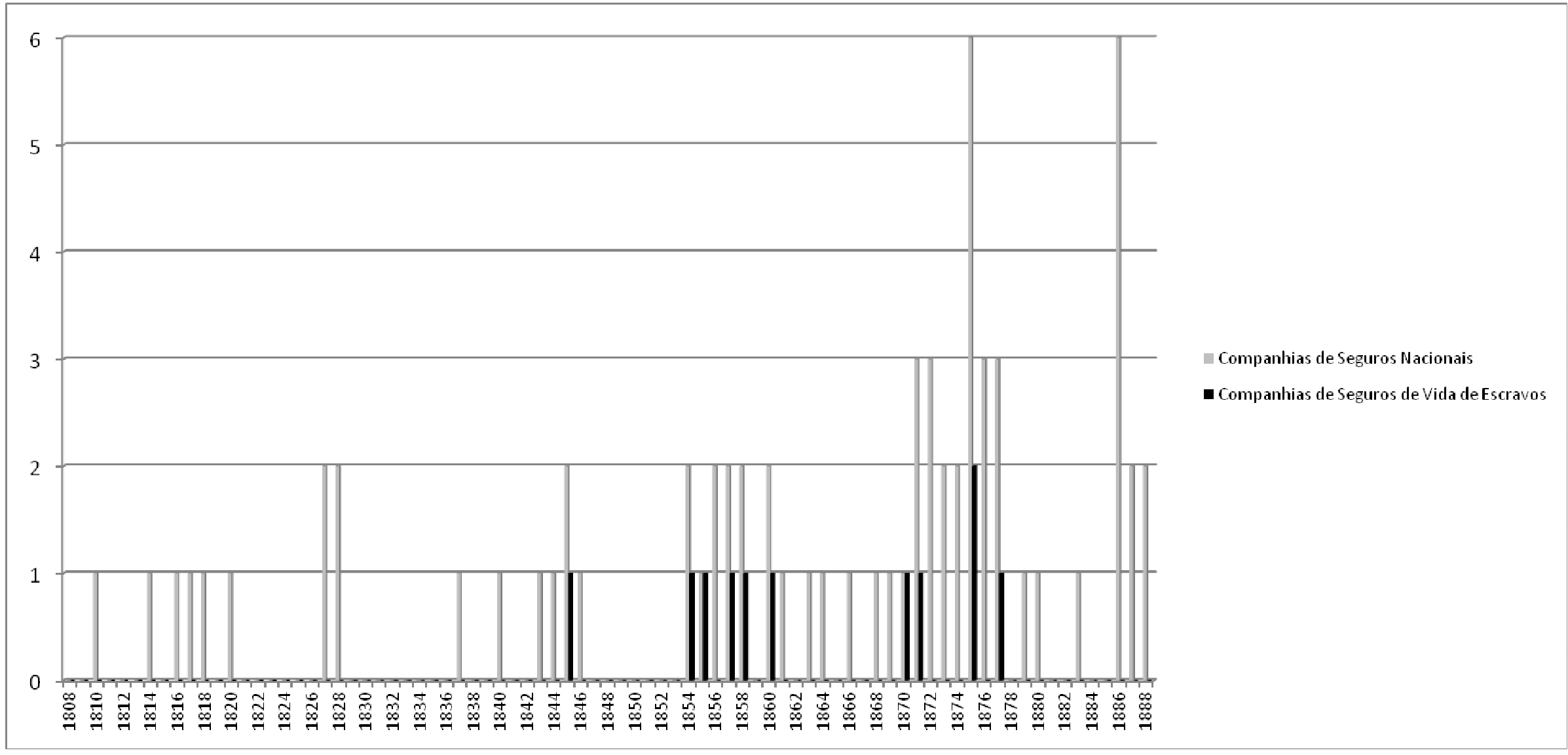

Fonte: Quadro Companhias de Seguros em funcionamento na Província do Rio de Janeiro (1808-1888), cf. Anexo 2. 
Nos Estados Unidos, muito embora poucas companhias já estivessem atuando nesse ramo do mercado durante os anos anteriores à década de 1840, período em que prevaleceria a contratação dos seguros de vida contra a perda dos escravos expostos aos riscos do comércio transatlântico, ou do tráfico interno; fora somente a partir de meados dos anos 1840, quando aquele mercado estivera favorável aos seguros de vida em geral, que mais seguradoras norte-americanas se disponibilizaram a atender a demanda dos proprietários que desejaram resguardar seus patrimônios. A Phenix Insurance Company of St. Louis, a Southern Mutual Insurance Company, a Greensborough Mutual Life Insurance and Trust Company, a Asheville Mutual Insurance Company, a Lynchburg Hose and Fire Insurance Company, a Richmond Fire Association, e The North Carolina Mutual Life Insurance Company, assim como a Aetna, a American International Group (AIG) e a New York Life, todas elas estiveram presentes na Carolina do Norte, na Virgínia, e em outros estados sulistas, e seguraram tanto os escravos favoritos dos senhores, como os que em não raras vezes foram alugados para trabalharem na construção de obras públicas, ferrovias, nas minas de carvão, na navegação, ou nas siderúrgicas ${ }^{164}$. Boa parte dos seguros contratados pela Aetna durante a década de 1850, por exemplo, seria para garantir os proprietários das perdas de seus escravos empregados nos serviços domésticos (com exceção de um, os outros nove eram do sexo feminino), no trabalho rural, como carroceiro ou como ferreiro. A variedade apresentada pela New York Life era maior, e do mesmo modo acaba se tornando um indicativo do uso que se fazia da propriedade escrava na sociedade norte-americana de meados do século XIX. Esta companhia chegou a segurar escravos que trabalharam no meio rural (empregados como agricultores, pescadores, no corte e na coleta de madeiras, etc.); nos serviços domésticos (como cozinheiros, alfaiates, padeiros, enfermeiros, costureiros, lavadeiras, etc.); fora de casa, nas ruas (seja exercendo qualquer atividade que não necessitasse de maior capacitação profissional, como

\footnotetext{
${ }^{164}$ Cf. SAVITT, Todd L., Slave life insurance in Virginia and North Carolina, p. 583-585. Chen e Simon parecem ter identificado com maior precisão a área de atuação das companhias de seguros New York Life, American International Group (AIG), e Aetna. A New Yor Life estendeu seus negócios aos estados do Alabama, Arkansas, Geórgia, Kentucky, Louisiana, Mississipi, Carolina do Norte, Carolina do Sul, Tennessee, Virgínia, e alguns outros que não foram mencionados nas 480 apólices emitidas entre os anos de 1845 e 1850. Durante esse período, seus principais mercados foram, em primeiro lugar, Kentucky (120 contratos de seguros) e, depois, o estado de Virgínia (100 contratos). Além de também ter atuado no Alabama, em Kentucky, e na Virgínia, a $A I G$ efetuou contratos no Distrito de Colúmbia, porém, assim como sua concorrente, teve mais presença no Kentucky: somente aí emitiu 127 apólices, de um total de 173 que negociou durante 1851-1853. Das 19 apólices emitidas pela Aetna entre 1853 e 1860, 10 foram para o estado do Missouri. Contudo, também contratou com proprietários da Louisiana (5), do Mississipi (1), da Carolina do Sul (2), e da Virgínia (1). Cf. CHEN, Cheryl Rhan-Hsin; SIMON, Gary, Acturial issues in insurance on slaves in the United States South, p. 351.
} 
carroceiros, por exemplo, ou no exercício de alguma profissão: manufatureiro, pedreiro, tipógrafo, carpinteiro, marceneiro, sapateiro, açougueiro, oleiro, ferreiro, barbeiro, armeiro, etc.), nas fábricas (nas serrarias, nas destilarias, etc.), no comércio (como vendedores de lojas ou ajudantes nos mercados, etc.), na mineração, mas sobretudo na navegação ${ }^{165}$.

No entanto, as companhias não subscreveram suas apólices com os olhos vendados às dificuldades que cotidianamente a classe trabalhadora enfrentava para garantir sua sobrevivência. Não desconheceram a precariedade que permeava a existência escrava, e à medida que ficavam mais experimentadas nesse negócio, aumentavam-se as exigências a serem observadas quando da contratação dessa espécie de seguros de vida. Antes que qualquer escravo fosse segurado, portanto, era imprescindível que fosse tomada ciência de seu real estado físico. Suas condições de saúde eram avaliadas normalmente por médicos que cobrariam uma taxa por cada exame feito, e seus relatórios fundamentariam as decisões dos administradores: os seguros não seriam realizados quando esses exames constatassem doenças ou problemas de saúde que porventura tornasse o contrato prejudicial aos interesses das seguradoras. Caso o negócio fosse conveniente, ainda assim os proprietários (que frequentemente seriam os próprios beneficiários) deveriam observar, durante a vigência do seguro, uma série de condições impostas por cada companhia que, se desobedecidas, poderiam muito bem justificar sua recusa ao pagamento das indenizações. Por exemplo, as seguradoras invariavelmente proibiram o livre trânsito dos escravos de um estado da federação para outro, ou mesmo entre algumas regiões, porque a mudança de temperatura ou do clima, ou ainda as doenças comuns a uma localidade específica, tudo isso poderia lhes comprometer o estado de saúde. Quando houvesse necessidade de deslocamento do escravo de um para outro lugar, seu proprietário deveria comunicá-la à companhia, e pedir-lhe autorização para fazê-lo. A permissão poderia the ser negada, ou concedida mediante o pagamento de um prêmio extra, que também caberia aos casos em que o escravo fosse alugado ou designado para trabalhar em ocupações dantes não estipuladas pelos contratantes ${ }^{166}$.

${ }^{165}$ CHEN, Cheryl Rhan-Hsin; SIMON, Gary, op. cit., p. 352-353.

${ }^{166}$ Muitas das condições estipuladas pelas seguradoras como forma de garantir o bom andamento de seus negócios, não há dúvida, acabaram por ocasionar algumas mudanças no tratamento dispensado pelos senhores aos seus escravos. Além das restrições impostas ao deslocamento e à ocupação, que evitariam a exposição excessiva do cativo a ambientes e a trabalhos hostis à sua saúde, as companhias frequentemente exigiram atestados médicos ou inquiriram testemunhas que pudessem comprovar a verdadeira causa da morte, ou lhes informar os cuidados recebidos pelo escravo quando ainda em seus últimos momentos de vida. Por outro lado, o contrário não deveria ser descartado. O surgimento dessas companhias no mercado poderia muito bem despertar a cobiça do proprietário, que ao invés de curar seu escravo enfermo, assisti-lo-ia sucumbir, ou mesmo aceleraria sua morte, pois assim, ao mesmo tempo em que se desfazia de uma 
Além disso, outro subterfúgio largamente praticado pelas seguradoras norteamericanas foi a estipulação de prazos não superiores a quatro ou cinco anos para o término dos contratos. Findo o período, a renegociação dos termos dos seguros talvez fosse muito vantajosa às companhias, pois em poucos anos as condições de saúde dos escravos poderiam se alterar radicalmente, para seu próprio prejuízo, e o de seu proprietário. Sendo assim, ao invés da renovação dos acordos firmados sob circunstâncias pretéritas, simplesmente; haveria possibilidade de se acrescentar novas cláusulas às apólices revistas, ou mesmo de se readequar o prêmio exigido aos novos riscos e à nova realidade do mercado. De todo modo, dificilmente as companhias subscreveriam uma apólice cujo valor correspondesse à totalidade do preço do escravo segurado. A Lynchburg Hose and Fire Insurance Company, por exemplo, garantiria o pagamento somente de três quartos do que ele valia no mercado, porém esse montante ainda estaria limitado a oitocentos dólares. $\mathrm{O}$ teto imposto por outra seguradora, The Richmond, seria ainda menor: não seguraria por mais de seiscentos dólares a vida de um escravo do sexo masculino com idade entre dezoito e quarenta anos, e que estivesse empregado para o trabalho nas ferrovias. E a North Carolina Mutual Life Insurance Company of Raleigh, por sua vez, não contrataria seguros cujo valor excedesse oitocentos dólares, ou dois terços do preço que o mercado atribuía ao escravo $^{167}$.

propriedade sem utilidade, receberia a indenização da seguradora cujo montante bem poderia ser empregado em outro qualquer investimento. Cf. SAVITT, Todd L., op. cit., p. 586-587; 592.

${ }^{167}$ Cf. SAVITT, Todd L., op. cit., p. 587-588; 589; 590; 591. A North Carolina Mutual Life Insurance Company of Raleigh chegou a subscrever suas apólices nos estados da Carolina do Norte e da Carolina do Sul, além de também estender suas operações a algumas regiões dos estados da Virgínia, Geórgia e Alabama. Já atuava no ramo dos seguros de vida de pessoas livres quando, no dia $1^{\circ}$ de abril de 1849 , deu início às contratações sobre a vida de escravos. Durante os 14 meses seguintes, entre a garantia de vidas escravas e livres, havia negociado um total de 610 apólices, e indenizado apenas duas mortes. Em 1851, este número seria quintuplicado (de duas, chegara a onze), enquanto a quantidade de apólices contratadas apenas duplicaria (1.161). Durante todos os onze anos em que a companhia North Carolina prosperou (1849-1860), seus dirigentes repensariam constantemente os termos dos seguros para, assim, readequá-los às mudanças econômicas ou aos novos riscos surgidos em prejuízo dos escravos e de seus negócios. Logo de sua estreia nesse ramo do mercado (1850-1851), por exemplo, o valor do prêmio a ser pago pelos proprietários que desejassem garantir a vida de suas propriedades sofrera um aumento de $15 \%$. Algum tempo depois, no dia 6 de setembro de 1851, a companhia decidiu que não mais arcaria com as indenizações decorrentes das perdas de escravos que morreram por falta de cuidados médicos adequados durante o período em que estiveram abatidos pela enfermidade. E, em junho de 1852 , imporia um novo reajuste de $15 \%$ ao prêmio dos seguros contratados. Contudo, foi durante a década de 1860, em meio ao desequilíbrio econômico provocado pela guerra civil norte-americana, que a North Carolina se viu obrigada a abandonar suas atividades. Um breve balanço ao final de suas operações acaba por indicar que a companhia comprometera-se a indenizar a morte de 265 escravos, dentre os milhares que por ela foram segurados (de mais de 7.200 seguros de vida contratados, cerca de metade a dois terços corresponderiam à garantia da propriedade cativa). A North Carolina Mutual Life Insurance Company of Raleigh foi uma das principais seguradoras de escravos dos estados da Carolina do Norte e da Carolina do Sul. Ibidem, p. 593-597; 600. 
Mais abaixo do continente, muitas dessas práticas administrativas aplicadas cotidianamente pelas companhias norte-americanas também foram conhecidas por várias companhias brasileiras, que de igual forma se dedicaram a negociar os seguros de vida de escravos. A maneira como as seguradoras nacionais atuariam no mercado, as condições impostas aos proprietários segurados, os cuidados tomados, enfim, para escapar aos prejuízos e à falência; um pouco desse comportamento pode ser conhecido pela leitura de alguns anúncios constantes das páginas do Almanak Laemmert, mas, principalmente, pela análise dos Estatutos que cada companhia fez subir ao governo imperial, na esperança de que fossem aprovados e, assim, autorizada sua incorporação e atuação na praça comercial do Rio de Janeiro, durante o século XIX. A Tabela 4 relaciona todos os Decretos e demais normas referentes a essas empresas, dando a conhecer, brevemente, a trajetória percorrida por cada uma em busca da legalização de suas atividades.

\section{Tabela 4: Decretos e demais normas referentes às Companhias de Seguros de vida de escravos autorizadas a funcionar na província do Rio de Janeiro, século XIX.}

\begin{tabular}{|c|c|c|}
\hline Série & Companhias & Decretos e demais normas \\
\hline $1(19)$ & $\begin{array}{l}\text { Companhia de Seguros } \\
\text { sobre a Vida dos } \\
\text { Escravos Prosperidade }\end{array}$ & - \\
\hline $2(30)$ & $\begin{array}{l}\text { Companhia de Seguros } \\
\text { Previdência }\end{array}$ & 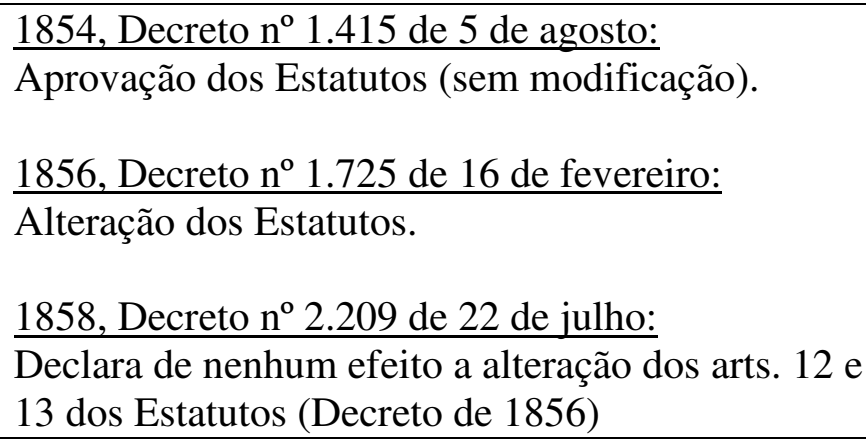 \\
\hline $3(39)$ & $\begin{array}{l}\text { Companhia de Seguros } \\
\text { Tranquilidade }\end{array}$ & $\begin{array}{l}1855, \text { Decreto } \mathrm{n}^{\circ} 1.669 \text { de } 7 \text { de novembro: } \\
\text { Autorização para a incorporação; aprovação dos } \\
\text { Estatutos. } \\
\frac{1858, \text { Decreto } n^{\circ} 2.101 \text { de } 6 \text { de fevereiro: }}{\text { Alteração dos Estatutos. }}\end{array}$ \\
\hline $4(42)$ & $\begin{array}{l}\text { Companhia Mútua de } \\
\text { Seguros de vida de } \\
\text { escravos }\end{array}$ & $\begin{array}{l}1858 \text {, Decreto } \mathrm{n}^{\circ} 2.078 \text { de } 16 \text { de janeiro: } \\
\text { Autorização para a organização; aprovação dos } \\
\text { Estatutos. } \\
\frac{1861, \text { Decreto } \mathrm{n}^{\circ} 2.815 \text { de } 14 \text { de agosto: }}{\text { Alteração dos Estatutos. }}\end{array}$ \\
\hline
\end{tabular}




\begin{tabular}{|c|c|c|}
\hline & & $\frac{1861 \text {, Decreto } \mathrm{n}^{\circ} 2.856 \text { de } 7 \text { de dezembro: }}{\text { Aprovação dos novos Estatutos. }}$ \\
\hline $5(44)$ & $\begin{array}{l}\text { Companhia de Seguros } \\
\text { Marítimos e Terrestres } \\
\text { Feliz Lembrançal } \\
\text { Companhia Geral de } \\
\text { Seguros União }\end{array}$ & $\begin{array}{l}\frac{1858, \text { Decreto } n^{\circ} 2.077 \text { de } 16 \text { de janeiro: }}{\text { Autorização para a organização; Aprovação dos }} \\
\text { Estatutos. } \\
\frac{1860, \text { Decreto } n^{\circ} 2.673 \text { de } 20 \text { de outubro: }}{\text { Aprovação das emendas aos Estatutos propostas pela }} \\
\text { Cia. } \\
\frac{1861, \text { Resolução do Ministério dos Negócios da }}{\text { Agricultura, Comércio e Obras Públicas } n^{\circ} 357, \text { de } 7} \\
\frac{\text { de junho: }}{\text { Declara que à Assembleia Geral dos sócios da Cia. }} \\
\text { compete a interpretação de seus Estatutos. } \\
\frac{1865, \text { Decreto } n^{\circ} 3.552 \text { de } 29 \text { de novembro: }}{\text { Autorização para a redução do capital da Cia. }} \\
\frac{1870, \text { Decreto } n^{\circ} 4.515 \text { de } 28 \text { de abril: }}{\text { Alteração dos Estatutos. }}\end{array}$ \\
\hline $6(52)$ & $\begin{array}{l}\text { Companhia de Seguros } \\
\text { Util-Previdência }\end{array}$ & $\frac{1860, \text { Decreto } \mathrm{n}^{\circ} 2.574 \text { de } 14 \text { de abril: }}{\text { Autorização para a organização. }}$ \\
\hline $7(71)$ & $\begin{array}{l}\text { Companhia de Seguros } \\
\text { União Fluminense }\end{array}$ & $\begin{array}{l}1870, \text { Decreto } \mathrm{n}^{\circ} 28 \text { de abril: } \\
\text { Autorização para a incorporação; aprovação dos } \\
\text { Estatutos. }\end{array}$ \\
\hline $8(77)$ & $\begin{array}{l}\text { Companhia de Seguros } \\
\text { Perseverança }\end{array}$ & $\begin{array}{l}\frac{1871, \text { Decreto } \mathrm{n}^{\circ} 4.829 \text { de } 23 \text { de novembro: }}{\text { Autorização para funcionar; aprovação dos }} \\
\text { Estatutos. }\end{array}$ \\
\hline $9(98)$ & $\begin{array}{l}\text { Companhia } \\
\text { Garantidora de Vidas }\end{array}$ & $\begin{array}{l}1875, \text { Decreto } n^{\circ} 6.030 \text { de } 6 \text { de novembro: } \\
\begin{array}{l}\text { Autorização para funcionar; aprovação dos Estatutos } \\
\text { (com modificações) }\end{array}\end{array}$ \\
\hline $10(99)$ & $\begin{array}{l}\text { Companhia de Seguros } \\
\text { Mútuos União }\end{array}$ & $\frac{1875, \text { Decreto } \mathrm{n}^{\circ} 6.058 \text { de } 14 \text { de dezembro: }}{\text { Aprovação dos Estatutos (com modificações) }}$ \\
\hline $\begin{array}{l}11 \\
(107)\end{array}$ & A Equitativa Brasileira & $\begin{array}{l}1877 \text {, Decreto } n^{\circ} 6.512 \text { de } 13 \text { de março: } \\
\text { Autorização para a fundação; aprovação dos } \\
\text { Estatutos (com modificações) }\end{array}$ \\
\hline
\end{tabular}

Fonte: Quadro Companhias de Seguros em funcionamento na Província do Rio de Janeiro (1808-1889), cf. Anexo 2; Coleção das Leis do Império do Brasil (1808-1889).

Os Estatutos da Companhia de Seguros Previdência (30), aprovados em $1854^{168}$, por exemplo, estabeleceram que a vida de nenhum escravo cuja idade fosse inferior a 12 anos, ou maior que 45 , poderia ser garantida por qualquer contrato (art. $1^{\circ}$ ). E para todos os outros que se adequassem a esse limite etário, antes, como condição ao fechamento do

${ }^{168}$ Cf. Decreto n ${ }^{\mathrm{o}} 1.415$, de 5 de agosto de 1854. 
negócio, teriam de ser estimados em seus domicílios "pelos Inspetores e Médicos da Companhia" (art. $\left.5^{\circ}\right)^{169}$. Muito provavelmente o exame de um escravo no seu próprio ambiente de sobrevivência permitiria que os médicos tomassem conhecimento de outras dimensões da realidade que cercava a vida do candidato ao seguro: a forma como era tratado, os perigos a que estava exposto no dia a dia, tudo isso contribuiria para uma avaliação mais certeira das reais condições sanitárias do cativo. Se, ao que parece, o exame não apontasse qualquer doença ou problema de saúde que comprometesse fatalmente a saúde do escravo, e portanto os negócios da companhia, a apólice seria subscrita, mas não "por maior prazo do que o de um ano" (art. $9^{\circ}$ ).

Segurada a propriedade, e perdido o escravo, haveria que se identificar a natureza de sua morte. Mais uma vez os médicos (peritos e inspetores) seriam chamados a representar a companhia no "lugar e domicílio do defunto" e atestar se o falecimento fora decorrente de causas naturais (art. $6^{\circ}$ ) ou não, pois, fora estabelecido pela própria Previdência, que a "Companhia não responde por morte resultando de sevícias, suicídio, assassinato, envenenamento, incêndio, desastre ou qualquer outra coisa que não seja a morte natural" (art. $4^{\circ}$ ). De posse, portanto, da apólice e do atestado que confirme esta cláusula, "o segurado terá direito à indenização estipulada" (art. $7^{\circ}$ ).

Caso o escravo continuasse com vida ao fim de um ano, o segurado poderia renovar a apólice, simplesmente, sem precisar se inquietar com o resultado de um novo exame médico. Durante os anos em que operou no Rio de Janeiro, a companhia Previdência preocupara-se, com certa frequência, em convencer os proprietários de que manter seus escravos seguros, permanentemente, seria uma ótima opção ao bem de seus próprios negócios; e, como parece, a dispensabilidade de uma nova avaliação das condições sanitárias dos cativos acabou por se configurar num incentivo para os segurados renovarem os compromissos com a companhia, sem maiores dificuldades. De todo modo, os anúncios publicados pelo Almanak Laemmert seguiriam ressaltando aos senhores que manter seus

\footnotetext{
${ }^{169}$ A Companhia de Seguros Previdência (30) empregava duas categorias de médicos: os médicos peritos e os médicos inspetores. Dentre os peritos participaram das atividades da companhia o Dr. Jules Level e o Dr. Pedro Maria de Almeida Portugal. O primeiro, de 1856 até 1858; e o segundo, permaneceu um ano a mais, até 1859. Os dois nomes empregados como médicos inspetores ocupariam o cargo desde 1856 até o último ano de atividade da Previdência (1859). O Dr. Francisco de Assis da Silva Ferreira, anos mais tarde, em 1878, seria contratado pela Companhia de Seguro Mútuo Contra Fogo (29). E em torno do segundo membro, o Dr. Antonio Martins Pinheiro, paira uma dúvida, pois não se sabe se é o pai, um cirurgião bem conhecido; ou se o filho, de mesmo nome, nascido no Rio de Janeiro no dia 12 de junho de 1824 e formado em medicina pela faculdade da mesma cidade, em 1848. Este, além de ter escrito a tese Dissertação sobre a histeria, apresentada na mesma faculdade, também em 1848, compôs várias peças para piano, dentre elas: Tarantella napolitana, Carlina, Gaúcha, Experiência, O raio, Vaidosa, Amor funesto, etc. Cf. BLAKE, Augusto Victorino Alves Sacramento, op. cit., vol. 1, p. 296.
} 
escravos seguros poderiam lhes facilitar futuras negociações no mercado, pois possíveis compradores "ficam por este fato conhecendo o estado sanitário do escravo que desejam comprar", ou "no caso de hipotecas, o seguro serve para maior garantia das dívidas" 170 .

Contudo, os argumentos favoráveis à realização dos seguros não necessariamente deveriam ultrapassar as portas das residências dos proprietários. Se segurar escravos poderia ser um ótimo negócio à companhia, também o poderia ser para os senhores que desejassem resguardar a inteireza de seus patrimônios. Dando mesmo a entender que seu alvo seria o mercado de escravos urbanos, continuava a propaganda afirmando que

\footnotetext{
Ninguém deixará de concordar na vantagem de tirar dos rendimentos de uma propriedade UMA PEQUENA parcela que garanta o seu valor total, segurando-se por exemplo um escravo no valor de..... mil réis, pagar-se-á um prêmio tão módico, que nem em trinta anos completará essa quantia, ao passo que a qualquer momento tem o direito de recebê-la por caso da morte do escravo seguro. ${ }^{171}$
}

Além de estabelecerem as condições e limites à contratação dos seguros de vida de escravos, os Estatutos da Previdência também organizaram a estrutura sob a qual a seguradora deveria ser gerida, ao mesmo tempo em que estabeleceram os direitos e deveres de seus membros (direção e acionistas), e prescreveram algumas normas na tentativa de regulamentar o relacionamento da empresa com o mercado e, em última instância, com o Estado.

A Previdência tivera seus Estatutos aprovados pelo governo imperial em 1854, mas só estaria autorizada a iniciar suas atividades, de fato, "logo que forem [fossem] subscritas metade de suas ações" (art. 10), pelo que parece esta seria uma condição indispensável à instituição da companhia. Uma vez instituída, os acionistas seriam chamados a "entrar com dez por cento do valor de suas respectivas ações" (art. 11), e o montante seria depositado “em um dos Bancos desta Corte" sendo "em conta corrente de juros" (art. 33). Se, dentro do prazo estipulado pela diretoria, algum acionista faltasse ao compromisso, ele então seria excluído e suas ações seriam "distribuídas a novos possuidores” (art. 11). Penalidade semelhante ser-lhe-ia aplicada caso não socorresse a companhia, a mando da diretoria, e dentro de 30 dias, em tempos de déficit em caixa (art. 28). Mas, caso a empresa não suportasse suas dificuldades, a "responsabilidade dos Acionistas pelas transações da Companhia não se estende a mais de valor de suas respectivas ações" (art. $3^{\circ}$ ).

${ }^{170}$ Cf. Almanak administrativo, mercantil e industrial do Rio de Janeiro - Almanak Laemmert, (1856), p. 377; (1858), p. 416-417; (1859), p. 448-449.

${ }^{171}$ Ibidem. 
Mas, ao que tudo indica, a Diretoria da Previdência, constituída por três diretores e dois gerentes, estivera em mãos de pessoas experientes no ramo segurador, ou que a ele ainda dedicariam grande parte do seu tempo no comércio. Até o ano de 1856, por exemplo, dois dentre os diretores também ocupariam cargos em outra seguradora estabelecida na praça comercial do Rio de Janeiro. O Conselheiro Ângelo Muniz da Silva Ferraz ${ }^{172}$ e o Dr. João Manoel Pereira da Silva foram, durante o biênio 1856-1857, o Secretário e o VicePresidente da Companhia de Seguros Marítimos e Terrestres (41), respectivamente. Os três diretores deveriam ser eleitos pela maioria dos votos dos acionistas, mas a assinatura de apenas um deles, em par com a de um dos dois gerentes, bastaria para as "apólices dos seguros e todos os mais atos" da companhia produzirem seus efeitos legais (art. 17).

Ao contrário dos diretores, os senhores Carlos Le Blon e Estevão Bernard, por terem sido os fundadores da Previdência assim como o fora G. Oelsner de Monmerqué, seriam "nomeados seus Gerentes inamovíveis" pelos próprios Estatutos (art. 13). Ambos participariam da gestão da seguradora desde a sua fundação (1854) até a época em que cessaria suas atividades (por volta de 1859), e também já contariam com alguma experiência no mercado segurador estabelecido na província do Rio de Janeiro. Le Blon já tinha sido agente da Phenix Fluminense (16) durante os anos de 1843 e 1844; e, entre 1845 e 1853, fora agente diretor da Reunião de Seguradores particulares de riscos marítimos (18). Esta Reunião era a antiga Companhia de Seguros Marítimos Seguridade (40), incorporada em 1856, e onde Le Blon permaneceria na gerência até o ano de 1862: em companhia de Estevão Bernard, sob a firma E. Bernard \& C Le Blon, entre os anos de 1856 e 1858; no ano seguinte, na sociedade C. Le Blon \& C. Nathan; assinando sozinho os atos da seguradora, entre 1860 e 1861; e, em 1862, sob a firma C. Le Blon \& A. Harper. Deste último sócio ainda seria colega de trabalho na Junta dos Seguradores Marítimos (54), no ano de 1861, quando então seria o Presidente, e Harper, o Secretário.

Além de seus cargos não dependerem dos votos dos acionistas, os gerentes (e também G. Oelsner de Monmerqué), por serem os fundadores da Previdência, fariam jus aos "três por cento sobre os prêmios de seguros que efetuar enquanto durar a sociedade" (art. 32), sobre os quais deveriam ser somados o rateio da "comissão de cinco por cento

172 Ângelo Muniz da Silva Ferraz nasceu em 1812, em Valença (Bahia). Formou-se em Direito pela Faculdade de Olinda em 1834, e logo exerceu os cargos de Promotor Público (cidade de Salvador) e Juiz de Direito (Jacobina). Além disso, foi nomeado Inspetor da Alfândega da Corte (1848), Juiz dos Feitos da Fazenda (1853), Ministro da Fazenda (1858) e Ministro da Guerra (1865). Representando a Bahia, chegou a ser eleito Deputado à Assembleia Geral durante 1842-1848. Em 1857, mesmo ano em que fora chamado a presidir a província do Rio Grande do Sul, tornou-se Senador do Império. Faleceu em Petrópolis, no Rio de Janeiro, em 1867. Cf. BLAKE, Augusto Victorino Alves Sacramento, op. cit., vol. 1, p. 119. 
sobre os prêmios de seguro que [a Diretoria] efetuar, a qual será dividida com igualdade entre os três Diretores ou suplentes que os substituírem, e os dois Gerentes" (art. 19). A Diretoria da seguradora ainda teria de se entender quando da nomeação de empregados (os gerentes nomeavam, mas suas opções dependeriam do consentimento dos diretores - art. 18), e seria sua tarefa convocar a Assembleia geral, momento em que deveria apresentar o "relatório do ano findo" (nas reuniões convocadas no mês de janeiro de cada ano, ocasião em que também teria lugar a eleição de um novo diretor - art. 20), mas que também seria propício aos acionistas votarem a aprovação dos empregados recém admitidos, o aumento do fundo capital (art. $2^{\circ}$ ), ou mesmo a dissolução da sociedade (art. 27) ${ }^{173}$.

Assim como as companhias coevas, de tempos em tempos (semestralmente) a Previdência repartiria "os lucros líquidos que houver, reservando-se um quinto deles e seus respectivos juros para se formar um fundo de reserva" (art. 26). Fora uma sociedade anônima, por direito, mas que na prática cotidiana percebera o atrativo que o mecanismo das sociedades (ou associações) mútuas poderia exercer sobre a decisão de possíveis clientes. O mesmo texto de propaganda que fizera circular nas publicações de 1856, 1858 e 1859 do Almanak Laemmert alardeava que

\begin{abstract}
Nos anos de prosperidade, os Segurados terão parte dos lucros, que tiverem sido realizados, e a quantia será deduzida dos prêmios a pagar, no ato da renovação da apólice, assim constituindo um seguro mútuo sem os segurados se responsabilizarem pelos prejuízos. ${ }^{174}$
\end{abstract}

Sociedades mútuas ou anônimas, o fato era que poderiam ser notadas muitas semelhanças entre as estruturas diretivas e administrativas de todas elas. Desde os postos de Direção, propriamente, como Presidente, Diretor, Gerente, Diretor Gerente, Fiscal,

\footnotetext{
${ }^{173}$ O Decreto $\mathrm{n}^{\mathrm{o}} 1.725$, de 16 de fevereiro de 1856 alterou os artigos 18 e 34 dos Estatutos originais da companhia de seguros Previdência e, ao que tudo indica, a nova redação retirou alguns poderes das mãos dos gerentes e os desviaram para os diretores e acionistas. O art. 18 passou a declarar que "as nomeações dos Empregados serão feitas pelos três Diretores, sobre proposta dos dois Gerentes. Os Diretores formam a direção suprema da Companhia, e os Gerentes farão cumprir as suas deliberações, bem como as da Diretoria. No caso de suscitar-se dúvidas a respeito da inteligência dos Estatutos ou de qualquer outra natureza, a Assembleia geral dos Acionistas será a competente para decidir, e suas decisões serão terminantes a respeito de todas as questões". O novo art. 34 não menciona o Conselho de direção que dantes fora criado para acompanhar e fiscalizar os trabalhos da Diretoria, mas sim marca as épocas de reunião e concede mais poderes às resoluções retiradas pelos acionistas quando em Assembleia geral. Toda essa mudança parece ter gerado um mal estar na companhia. A ordem que viria com um outro Decreto, o de $n^{\circ} 2.209$ de 23 de julho de 1858, acabou concordando com o entendimento dos gerentes (e dos herdeiros de Monmerqué) e declarou o Decreto anterior sem efeito naquilo que atingisse os "direitos, e prerrogativas que nos arts. 12 e 13 dos referidos Estatutos foram assegurados aos suplicantes como Diretores, Gerentes, autores e fundadores da Companhia".

${ }^{174}$ Cf. Almanak administrativo, mercantil e industrial do Rio de Janeiro - Almanak Laemmert, (1856), p. 377; (1858), p. 416-417; (1859), p. 448-449.
} 
Caixa, etc.; até as demais funções administrativas ou de escritório, como a de Médico, Caixa, Guarda-Livros, Secretário, Escriturário, Cobrador, Porteiro, Ajudante, Contínuo (ou Entregador); todos eles seriam cargos que, invariavelmente, estiveram presentes na montagem das companhias e, como peças da engrenagem, colocariam a máquina empresarial para funcionar.

Por outro lado, algumas diferenças puderam ser observadas quando de uma leitura comparativa dos Estatutos das seguradoras, portanto, das organizações por que optaram cada uma delas. Um ou outro detalhe que bem poderiam dar conta de individualizá-las no comércio, muito embora subordinados e insertos em estruturas jurídicas ou administrativas maiores, que ainda sustentavam certa semelhança entre si, e que muito provavelmente foram características de uma época. Essas distinções puderam ser localizadas na composição financeira das companhias, por exemplo, que dividiriam seu capital em um número variado de ações, que deveriam ser parcialmente subscritas como condição ao início de suas atividades; e que dariam ao fundo disponível destinos diversos a serem escolhidos dentre as possibilidades de investimento no mercado, conforme pode ser visualizado pela Tabela 5 .

Outro campo da estrutura social que conheceria o toque peculiar dos sócios seria a organização da gestão da companhia. Embora frequentemente uma Direção estivesse presente em todas elas, cada uma, ao seu modo, estipularia os números de diretores e de gerentes a serem responsáveis pelo bom andamento dos negócios; a quantidade de ações que cada acionista deveria possuir para se candidatar a qualquer um desses cargos e; caso fosse eleito para um deles, o tempo que lhe seria permitido exercer o mandato, e as remunerações que poderiam retirar pelos serviços prestados. Quando em 1859, por exemplo, alguns acionistas da Companhia de Seguros Previdência requereram ao governo imperial "autorização para organizar outra nova Companhia com a denominação de - Util Previdência -, para o fim de substituir aquela, e liquidá-la" ${ }^{\text {175 }}$, os Estatutos por eles sugeridos foram aprovados sem modificações, e traziam consigo uma forma de organização distinta da que conhecera a gestão da antiga seguradora.

${ }^{175}$ Decreto $^{\mathrm{o}} 2.574$, de 14 de abril de 1860. 
Tabela 5: Capital e destino dos fundos das Companhias seguradoras de vida de escravos autorizadas a funcionar na Província do Rio de Janeiro

\begin{tabular}{|c|c|c|c|}
\hline Série & Companhia & Capital/ Ações & Destino do Fundo \\
\hline $1(19)$ & $\begin{array}{l}\text { Companhia de Seguros } \\
\text { sobre a Vida dos } \\
\text { Escravos Prosperidade }\end{array}$ & - & - \\
\hline $2(30)$ & $\begin{array}{l}\text { Companhia de Seguros } \\
\text { Previdência }\end{array}$ & $\begin{array}{l}\text { - 2.000:000 } \$ 000 \text { (dois mil contos de réis): } 2.000 \\
\text { ações de 1:000\$000 (um conto de réis cada) (Art. } \\
2^{\circ}, \text { Dec. } n^{\circ} 1.415 \text {, de } 5 \text { de agosto de } 1854 \text { ). }\end{array}$ & $\begin{array}{l}\text { - "Em um dos Bancos desta Corte serão depositados os fundos da } \\
\text { Companhia em conta corrente de juros" (Art. 33, Dec. } \mathrm{n}^{\circ} 1.415 \text {, } \\
\text { de } 5 \text { de agosto de 1854). }\end{array}$ \\
\hline $3(39)$ & $\begin{array}{l}\text { Companhia de Seguros } \\
\text { Tranquilidade }\end{array}$ & $\begin{array}{l}\text { - 6.000:000 } \$ 000 \text { (seis mil contos de réis): } 6.000 \\
\text { ações de 1:000\$000 (um conto de réis cada) (Art. } \\
2^{\circ}, \text { Dec. } n^{\circ} 1.669 \text {, de } 7 \text { de novembro de } 1855 \text { ). }\end{array}$ & $\begin{array}{l}\text { - "Os fundos da Companhia serão depositados em conta corrente } \\
\text { de juros na sociedade bancária de Mauá-Mac-Gregor \& C.a, ou } \\
\text { n'outra qualquer que ofereça melhores vantagens" (Art. 32, Dec. } \\
\text { nº } 1.669 \text {, de } 7 \text { de novembro de 1855). }\end{array}$ \\
\hline $4(42)$ & $\begin{array}{l}\text { Companhia Mútua de } \\
\text { Seguros de vida de } \\
\text { escravos }\end{array}$ & $\begin{array}{l}\text { “(...) e logo que haja subscritos três mil contos de } \\
\text { reis [3.000:000\$000] de riscos, se considerará a } \\
\text { Companhia incorporada" (Art. } 3^{\circ}, \text { Dec. n }{ }^{\circ} 2.078 \text {, de } \\
16 \text { de janeiro de 1858; Art. } 3^{\circ}, \text { Dec. } n^{\circ} 2.856 \text {, de } 7 \\
\text { de dezembro de 1861). }\end{array}$ & $\begin{array}{l}\text { - "Os fundos da Companhia serão recolhidos a uma das caixas } \\
\text { bancárias da Corte em conta corrente de juros" (Art. 50, Dec. no } \\
2.078 \text {, de } 16 \text { de janeiro de 1858). } \\
\text { - "Os fundos da Companhia serão recolhidos a uma das casas } \\
\text { bancárias da Corte em conta corrente de juros" (Art. 62, Dec. no } \\
\text { 2.856, de } 7 \text { de dezembro de 1861). }\end{array}$ \\
\hline $5(44)$ & $\begin{array}{l}\text { Companhia de Seguros } \\
\text { Marítimos e Terrestres } \\
\text { Feliz Lembrançal } \\
\text { Companhia Geral de } \\
\text { Seguros União }\end{array}$ & $\begin{array}{l}\text { - 5.000:000 } \$ 000 \text { (cinco mil contos de réis): } 10.000 \\
\text { ações de } 500 \$ 000 \text { (quinhentos mil réis cada) (Art. } \\
\left.2^{\circ}, \text { Dec. } n^{\circ} 2.077 \text {, de } 16 \text { de janeiro de } 1858\right) \text {. } \\
\text { - 2.000:000 } \$ 000 \text { (dois mil contos de réis) (Dec. } \mathrm{n}^{\mathrm{o}} \\
\text { 3.552, de } 29 \text { de novembro de } 1865 \text { ). } \\
\text { - 1.200:000 } \$ 000 \text { (mil e duzentos contos de réis): } \\
\text { 1.200 açôes de 1:000 } \$ 000 \text { (um conto de réis cada) } \\
\text { (Dec. } \mathrm{n}^{\circ} 4.515 \text {, de } 28 \text { de abril de } 1870 \text { ). }\end{array}$ & $\begin{array}{l}\text { - "Todo o dinheiro disponível terá a seguinte aplicação: Metade } \\
\text { depositar-se-á em qualquer dos Bancos acreditados, ou } \\
\text { empregar-se-á em bilhetes do Tesouro Nacional ou da } \\
\text { Alfândega, e a outra metade será empregada em ações da estrada } \\
\text { de ferro de D. Pedro II, e em títulos de igual natureza garantidos } \\
\text { pelo Governo" (Art. 5०, Dec. nº } 2.077 \text {, de } 16 \text { de janeiro de 1858). } \\
\text { - "Todo o dinheiro disponível terá a seguinte aplicação: metade } \\
\text { depositar-se-á em qualquer dos bancos acreditados, e a outra } \\
\text { metade empregar-se-á em bilhetes do Tesouro Nacional ou da } \\
\text { Alfândega, ou em títulos de igual natureza e garantidos pelo } \\
\text { Governo" (Nova redação do art. } 5^{\circ} \text {, dada pelo Dec. nº } 4.515 \text {, de } \\
28 \text { de abril de 1870). }\end{array}$ \\
\hline $6(52)$ & Companhia de Seguros & - 2.000:000\$000 (dois mil contos de réis): 2.000 & - "Em um dos Bancos desta Corte serão depositados os fundos da \\
\hline
\end{tabular}




\begin{tabular}{|c|c|c|c|}
\hline & Util-Previdência & $\begin{array}{l}\text { ações de 1:000\$000 (um conto de réis cada) (Art. } \\
\left.2^{\circ} \text {, Dec. } \mathrm{n}^{\circ} 2.574 \text {, de } 14 \text { de abril de } 1860\right)\end{array}$ & $\begin{array}{l}\text { Companhia em conta corrente de juros" (Art. 28, Dec. no } 2.574 \text {, } \\
\text { de } 14 \text { de abril de } 1860 \text { ). }\end{array}$ \\
\hline $7(71)$ & $\begin{array}{l}\text { Companhia de Seguros } \\
\text { União Fluminense }\end{array}$ & $\begin{array}{l}\text { “A companhia será instalada (...) depois que se } \\
\text { acharem inscritos, para serem seguros, valores que } \\
\text { representem, pelo menos, a importância de } \\
\text { 500:000\$000 [quinhentos contos de réis] (...)." } \\
\left.\text { (Art. } 2^{\circ} \text {, Dec. } \mathrm{n}^{\circ} 4.513 \text {, de } 28 \text { de abril de } 1870\right) \text {. }\end{array}$ & $\begin{array}{l}\text { "A importância total dos prêmios será recolhida a um banco (...)" } \\
\text { (Art. 21, Dec. } n^{\circ} 4.513 \text {, de } 27 \text { de abril de } 1870 \text { ). }\end{array}$ \\
\hline $8(77)$ & $\begin{array}{l}\text { Companhia de Seguros } \\
\text { Perseverança }\end{array}$ & $\begin{array}{l}\text { - 1.000:000 } \$ 000 \text { (mil contos de réis): } 2.000 \text { ações de } \\
500 \$ 000 \text { (quinhentos mil réis cada) (Art. } 1^{\circ} \text {, Dec. } \\
\mathrm{n}^{\circ} 4.829 \text {, de } 23 \text { de novembro de } 1871 \text { ) }\end{array}$ & $\begin{array}{l}\text { - “A importância total dos prêmios, à proporção que se liquidar, } \\
\text { será recolhida a um banco, e dele só será retirada a parte } \\
\text { concernente à indenização dos sinistros e mais despesas } \\
\text { ocorridas durante o ano social" (Art. 27, Dec. } \mathrm{n}^{\circ} 4.829 \text {, de } 23 \text { de } \\
\text { novembro de 1871). }\end{array}$ \\
\hline $9(98)$ & $\begin{array}{l}\text { Companhia } \\
\text { Garantidora de Vidas }\end{array}$ & $\begin{array}{l}-1.000: 000 \$ 000 \text { (mil contos de réis): } 5.000 \text { ações de } \\
\text { 200\$000 (duzentos mil réis cada) (Art. } 4^{\circ}, \text { Dec. } \mathrm{n}^{\circ} \\
\text { 6.030, de } 6 \text { de novembro de } 1875 \text { ) }\end{array}$ & $\begin{array}{l}\text { - "Todas as quantias recebidas, seja qual for a sua origem, serão } \\
\text { depositadas no Banco que maiores garantias oferecer na opinião } \\
\text { da Diretoria, guardando-se unicamente nos cofres da Companhia } \\
\text { o dinheiro necessário para o pagamento das despesas e custeio da } \\
\text { mesma" (Art. } 28 \text {, Dec. no } 6.030 \text {, de } 6 \text { de novembro de } 1875 \text { ). }\end{array}$ \\
\hline $\begin{array}{l}10 \\
(99)\end{array}$ & $\begin{array}{l}\text { Companhia de Seguros } \\
\text { Mútuos União }\end{array}$ & $\begin{array}{l}\text { - “(..) formando o fundo social as contribuições dos } \\
\text { sócios que subscreverem os presentes estatutos e } \\
\text { condições de seguro" (Art. } 1^{\circ}, \text { Dec. nº } 6.058, \text { de } 14 \\
\text { de dezembro de 1875). }\end{array}$ & $\begin{array}{l}\text { - "Os fundos recolhidos à caixa da Associação, provenientes dos } \\
\text { prêmios pagos pelos sócios, serão convertidos em apólices da } \\
\text { dívida pública nacional, e a aquisição será feita por intermédio de } \\
\text { um corretor" (Art. } 9^{\circ} \text {, Dec. n }{ }^{\circ} 6.058 \text {, de } 14 \text { de dezembro de } \\
\text { 1875). }\end{array}$ \\
\hline $\begin{array}{l}11 \\
(107)\end{array}$ & $\begin{array}{l}\text { A Equitativa } \\
\text { Brasileira }\end{array}$ & $\begin{array}{l}\text { - "O seu capital será constituído com as contribuições } \\
\text { dos associados que tenham subscrito, ou forem } \\
\text { subscrevendo os presentes estatutos" (Art. 2, Dec. } \\
\text { no } 6.512 \text {, de } 13 \text { de março de 1877). }\end{array}$ & $\begin{array}{l}\text { - "Dos capitais recebidos pela Associação, provenientes das } \\
\text { prestações pagas pelos associados, duas terças partes serão } \\
\text { imediatamente convertidas em apólices da dívida pública geral } \\
\text { ou provincial, quando gozem dos mesmos privilégios, ou em } \\
\text { bilhetes do Tesouro, ou em letras hipotecárias de Bancos de } \\
\text { crédito real que tenham a garantia do Governo; sendo a escolha } \\
\text { desses títulos do prudente arbítrio da Direção" (Art. } 4^{\circ} \text {, redação } \\
\text { modificada pelo Dec. } n^{\circ} 6.512 \text {, de } 13 \text { de março de } 1877 \text { ). }\end{array}$ \\
\hline
\end{tabular}

Fonte: Fonte: Quadro Companhias de Seguros em funcionamento na Província do Rio de Janeiro (1808-1889), cf. Anexo 2; Coleção das Leis do Império do Brasil (18081889). 
A Companhia de Seguros Util-Previdência, então, acabou com todas as prerrogativas que competiam aos antigos gerentes da Previdência (Carlos Le Blon e Estevão Bernard; mas também ao terceiro fundador G. Oelsner Monmerqué), e prescreveu novas regras às quais estivera subordinada a nova direção. A Util-Previdência passou a ser "administrada por um gerente, eleito anualmente por maioria absoluta dos votos presentes, com a gratificação e porcentagem do rendimento líquido que for marcado pela assembleia geral dos acionistas" (art. 11). Para "fiscalizar os atos da gerência, autorizar todos os pagamentos e velar na exata observação dos estatutos e regulamentos", um Conselho Fiscal seria eleito anualmente, também pela maioria dos votos dos acionistas reunidos em assembleia (art. 12). Das fontes consultadas, a única que chega a informar os nomes dos negociantes envolvidos na administração da nova companhia foi uma chamada constante do Almanak Laemmert publicado no ano de $1861^{176}$. Dos três diretores, Guilherme Pinto de Magalhães viria a ser, futuramente, membro efetivo do Conselho Fiscal da Sociedade de Seguros Mútuos sobre a vida Protetora das Famílias (61) por poucos anos (1866-1868), mas vinha da Diretoria da companhia Previdência, cargo que exerceu durante os anos de 1857 e 1859. Aí fora colega de Francisco José Gonçalves - diretor desde 1856 até 1859 -, que em 1854 e em 1861 seria o Diretor anual da Companhia de Seguro Mútuo Contra Fogo (29), e membro do seu Conselho de Administração durante os anos compreendidos entre 1858 e 1862. O Gerente, tão limitado, foi Estevão Bernard, o mesmo que conhecera maior liberdade de ação nos seus tempos de Previdência.

A presença de um Conselho Fiscal, muito embora fosse uma inovação para os acionistas que estiveram habituados à administração daquela antiga companhia, contudo não o fora para grande parte das seguradoras de escravos coevas, ou que ainda viriam a se estabelecer no mercado carioca. Nem mesmo teria sido estranho dentre os órgãos de direção das associações mútuas, como a Companhia Mútua de Seguros de vida de escravos (42). Em 1861, seus novos Estatutos aprovados e publicados pelo Decreto $\mathrm{n}^{\circ} 2.856$, de 7 de dezembro, prescreveram que a "administração da Companhia será confiada à um Conselho composto de nove pessoas, e dois gerentes eleitos pela assembleia geral à pluralidade de votos" (art. $4^{\circ}$ ), que exerceriam os cargos por seis anos (art. 12), e seriam os responsáveis por "dirigir o escritório da Companhia" e representá-la nos tribunais (art. 13, § $1^{\circ}$ e $3^{\circ}$ ). Os gerentes, juntamente com o diretor, comporiam a Diretoria da associação Mútua, cujas atribuições estariam estritamente subordinadas à aprovação dos fiscais: deveriam sugerir as

\footnotetext{
${ }^{176}$ Cf. Almanak administrativo, mercantil e industrial do Rio de Janeiro - Almanak Laemmert, 1861, p. 400.
} 
contratações e demissões de empregados, elaborar os regulamentos internos e executá-los, depois de chancelados, e também "executar todas as deliberações tomadas pelo Conselho" (art. 15). A duração dos mandatos que deveriam exercer cada membro do Conselho seria de três anos (art. $5^{\circ}$ ), e uma vez terminada obrigaria a organização de novas eleições. Finda esta disputa, dentre os nove candidatos mais bem votados, o primeiro seria o Presidente do Conselho, "que ao mesmo tempo é o Diretor, servindo de Secretário o terceiro em votos; os imediatos serão suplentes do Diretor e do Secretário" (art. $8^{\circ}$ ). Além das incumbências sobre as tarefas da Diretoria, ainda ser-lhes-ia cabido autorizar ou desaprovar outras despesas que não as previstas pelos Estatutos, e zelar pelo bom andamento dos negócios de uma companhia mútua (art. 10), onde todo proprietário de escravos seria ao mesmo tempo o segurado e o segurador.

A mutualidade, segundo as próprias palavras da administração da Mútua de escravos, nome pelo qual também fora conhecida no mercado carioca, seria muito mais vantajosa aos senhores que desejassem segurar suas propriedades, talvez porque estivesse amparada nos valores solidários que deveriam governar uma sociedade fraterna, o que acabaria por repercutir na justeza do valor dos prêmios a serem pagos pelos seguros. As propagandas veiculadas pela companhia nas páginas do Almanak Laemmert durante o último lustro da década de 1850 e o início da de 1860, acabaram por seguir esse caminho, o de convencer possíveis associados de que entrariam para um bom negócio. $\mathrm{O}$ anúncio que saiu em 1860 tentara, ao que parece, informar ao público a maneira que companhia operava seus negócios, mediante o esclarecimento mesmo do que viria a ser a mutualidade empregada no seguro de vida de escravos. Dizia o texto que

\footnotetext{
Sendo esta companhia uma associação entre os senhores de escravos, e os prêmios dos seguros destinados unicamente a indenizar os prejuízos que para os mesmos possam resultar da mortalidade, é evidente que esta classe de seguros é simplesmente a compensação exata da perda a que estão sujeitos alguns sócios, indenizada com os fundos de todos os sócios.

No fim do ano do seguro, a parte do fundo social que sobejar, depois de deduzidos os sinistros e gastos da companhia, reverte a favor de cada sócio em proporção de suas entradas, e constitui assim não um lucro, mas uma indenização de perda; outrossim, se os prejuízos excederem ao fundo social, cada sócio deverá entrar em um rateio unicamente em proporção de seus seguros. ${ }^{177}$
}

E continuava, porém, comparando-a ao que comumente era praticado pelas sociedades anônimas na praça comercial do Rio de Janeiro:

${ }^{177}$ Cf. Almanak administrativo, mercantil e industrial do Rio de Janeiro - Almanak Laemmert, 1860, p. 451452 
Desta breve exposição se pode coligir uma diferença bem notável entre o sistema mútuo e o seguro a prêmio, o qual não pode existir sem prévia tenção da parte dos acionistas de uma tal empresa de realizar um lucro mercantil sobre os prêmios pagos pelos segurados; assim no seguro mútuo o segurado pagará só o verdadeiro importe do seguro, enquanto que em uma companhia de seguro a prêmio terá ele forçosamente de pagar de mais o lucro que pode reverter a favor dos acionistas da dita companhia. ${ }^{178}$

As propagandas da companhia também não deixaram de rebater algumas das críticas que lhe lançaram as concorrentes da mutualidade, sem que, contudo, deixasse de observar a ocorrência de certos movimentos naquele mercado segurador, especificamente a apropriação desse mesmo mecanismo da mutualidade por parte das seguradoras constituídas sob a forma de sociedades anônimas - sejam elas garantidoras de vidas de escravos, simplesmente, como também as que se dedicavam à contratação de outros riscos terrestres, marítimos, ou fluviais. O anúncio publicado pelo Almanak Laemmert de 1859 poderia muito bem estar se referindo, dentre outras, à Companhia de Seguros Previdência (30), que repartiria parte de seus lucros em tempos de bonança. Dizia ela que

\begin{abstract}
As vantagens do seguro feito segundo o sistema de mutuidade [sic] são tão sensíveis que as mesmas companhias a prêmio já vão reformando-se segundo esse sistema, para não perder clientela. Os riscos de rateio que os adversos a esse sistema procuram incutir nas pessoas menos ilustradas, para assim retirá-las desta forma de seguro, é apenas um fantasma que desaparece diante dos olhos desprevenidos pela mais simples reflexão. ${ }^{179}$
\end{abstract}

De todo modo, o mecanismo adotado pela Companhia Mútua de Seguros de vida de escravos (42) parece ter surtido bons efeitos aos seus cofres e aos bolsos dos sócios. Pelo menos é o que pode ser lido nos primeiros anúncios que publicara no Almanak. Um dos apelos publicitários de que lançaria mão para convencer os proprietários a aderirem à sociedade consistira em colocar naquela vitrine uma amostra do estado financeiro da companhia, que parecia mesmo ter-lhe sido favorável. As informações trazidas junto à chamada de 1860 confirmavam que mais de 5.000:000\$000 (cinco mil contos de réis) perfaziam o valor total dos riscos contratados em menos de dois anos de funcionamento e que, ao fim da distribuição dos dividendos, o preço dos prêmios caiu de três, para pouco mais de $2 \%$ do valor da avaliação dos escravos. Pelos anúncios publicados em 1861 e 1862, a seguradora vangloriava-se ainda mais, pois "contando apenas três anos de

\footnotetext{
${ }^{178}$ Ibidem.

${ }^{179}$ Cf. Almanak administrativo, mercantil e industrial do Rio de Janeiro - Almanak Laemmert, 1859, p. 447.
} 
existência, o capital nela seguro já sobe a mais de 7,000:000\$000 [sete mil contos de réis]" ${ }^{180}$. Além do mais, o montante das entradas já tinha possibilitado a criação de um fundo de reserva que garantisse o patrimônio dos próprios associados "caso os sinistros e despesas absorvam toda a importância dos prêmios arrecadados e seus juros"181.

Mas, pelas fontes consultadas, o sucesso dos negócios da companhia parece ter se concentrado mesmo nesses seus primeiros anos de vida. Passado nem tanto tempo assim, em 1866, a Comissão liquidadora da Mútua de escravos fora autora de um processo levado ao Juízo de Paz da Freguesia da Glória do Rio de Janeiro, em face de Antonio Luiz Coimbra de Gouvêa que, por conta de D. Maria Feliciana de Vasconcellos Coimbra, assinara a apólice $\mathrm{n}^{\mathrm{o}} 3.126$, segurando o escravo Ezequiel, crioulo de 22 anos, mediante o prêmio de $23 \$ 450$ (vinte e três mil, quatrocentos e cinquenta réis). A apólice, prova do vínculo que Antonio mantinha com a companhia, fora subscrita no dia 8 de outubro de 1862 pelo diretor Cândido José de Vitória e por um dos dois gerentes: ou o Sr. Gaston de Lailhacar, que permaneceria neste cargo de 1857 a 1863; ou Lourenço José de Aguiar, cuja gerência cessara um ano antes (1857-1862), mas que já tinha sido empregado da Companhia de Seguro Mútuo Contra Fogo (29) durante o biênio 1856-1857, e, ao que tudo indica, deixaria a associação para ocupar o cargo de Diretor-gerente da Companhia de Seguro Mútuo contra o fogo Alliança (57).

A contenda parece ter sido ocasionada pela negativa de Antonio Luiz Coimbra de Gouvêa em pagar o que de direito à companhia. A Comissão liquidadora reclamava em petição o recebimento de $10 \$ 000$ (dez mil réis), acrescidos os juros e demais custas, e obtivera uma sentença favorável ao final do litígio. O montante principal corresponderia ao valor do quinhão que caberia a Gouvêa quitar em decorrência do " $2^{\circ}$ rateio de $2 \%$ sobre os capitais responsáveis em 31 de Março de 1863, época em que tinha seguro o valor de quinhentos mil réis (...)". Fora uma fatalidade, e se alguns cuidados tivessem sido tomados talvez nem Gouvêa, nem outros sócios fossem chamados a recompor o fundo necessário a dar liquidez à companhia. Os erros cometidos só puderam ser percebidos anos mais tarde, quando nomeada uma comissão de reforma, que ficara encarregada de buscar respostas ao ocorrido. Na sessão extraordinária da assembleia geral do dia 9 de junho de 1863, essas causas foram conhecidas, e alguns encaminhamentos foram sugeridos, quando, então,

\footnotetext{
${ }^{180}$ Cf. Almanak administrativo, mercantil e industrial do Rio de Janeiro - Almanak Laemmert, 1861, p. 397; 1862, p. 408.

181 Ibidem.
} 
(...) procedeu-se à leitura do parecer da mesma comissão de reforma, e obtendo a palavra o Sr. Dr. Garnier, membro da mesma, esclareceu à assembleia sobre as causas que levaram a Companhia à penosa posição em que hoje se acha, e mostrou com cálculos baseados nos próprios livros da Companhia, que, se não se distribuíssem dividendos nos anos anteriores, os lucros convertidos em fundos de reserva, teriam largamente chegado para o pagamento de todos os sinistros, evitando assim a Companhia a diminuição sucessiva do numero de seus seguros, resultado do descrédito ocasionado pela demora nos pagamentos dos sinistros, e desta exposição o mesmo Sr. sócio corroborou a opinião da comissão, de, para o futuro serem levados os lucros, ou parte deles em fundo de reserva. ${ }^{182}$ (Grifamos)

Como se vê, parece que toda essa situação em que se viu envolvida a Mútua de escravos durante boa parte da década de 1860, todas essas dificuldades, enfim, permeariam suas decisões e suas atividades, e acabariam por justificar suas atitudes perante o corpo mercantil do Município Neutro e o de Niterói, circunscrição que delimitara para a realização de seus negócios (art. $2^{\circ}$, Novos Estatutos). A “demora nos pagamentos dos sinistros" muito provavelmente consistira num desses subterfúgios administrativos recorridos pela companhia para aliviar seus negócios de uma crise maior, e que poderia comprometer ainda mais sua sobrevivência já tão afetada pelas circunstâncias que a rodeavam desde o primeiro lustro desse decênio.

Talvez nesse contexto coubesse o sentido do Sr. José Maximiano dos Santos ter intentado uma ação judicial contra a Diretoria da Companhia Mútua de seguros de vida de escravos na esperança de receber uma indenização no valor de 1:500\$000 (um conto e quinhentos mil réis). Abel, de 19 anos de idade, empregado como copeiro, provavelmente um escravo de ganho, fora segurado por seu proprietário no dia 3 de junho de 1862 , mediante o pagamento do prêmio estipulado em $52 \$ 500$ (cinquenta e dois mil e quinhentos réis), sob as condições constantes da apólice emitida com o $\mathrm{n}^{\mathrm{0}}$ 7.507. Entre petições, atestado de óbito do escravo, agravos, contestação, réplica, tréplica, embargos e apelações, enfim, a sentença e o acórdão foram desfavoráveis à companhia, então condenada ao pagamento da quantia pedida pelo autor, acrescidos os juros legais da mora, após uma

${ }^{182}$ Cf. BRASIL. Juízo de Paz da Freguezia da Glória. Processo n. 3025. Arquivo Nacional do Rio de Janeiro, ZO, CODES, Maço 845, 1866. A Comissão liquidadora da Companhia Mútua de seguros de vida de escravos havia sido convocada na sessão extraordinária da assembleia geral que tomou assento no dia 6 de fevereiro de 1865. Dela fizeram parte José Antonio Fernandes (sócio e credor), que também seria o Presidente da companhia de 1864 a 1866; Antonio José Pereira Bastos (sócio e credor), que ocuparia o cargo de Secretário da associação entre 1864 e 1866; e Antônio Alves (ou Álvares) Pereira Coruja, que além de também ter sido Secretário da Mútua de escravos, porém no biênio 1865-1866, chegou a ser Presidente da Companhia de Seguros Marítimos e Terrestres Feliz Lembrança (44) em 1870, ano em que passaria a ter outra denominação: Companhia Geral de Seguros União. 
possível tentativa de escapar, ou ao menos adiar ao máximo o cumprimento de suas responsabilidades ${ }^{183}$.

Tanto o escravo Ezequiel como Abel foram segurados porque suas condições sanitárias foram aprovadas por algum dos médicos empregados pela Mútua de escravos. Tanto um como outro provavelmente foram avaliados pelo Dr. José Manoel da Silveira, que fez parte dos quadros da companhia durante o período 1860-1863, e que tempos depois seria convidado a examinar os escravos segurados pela Companhia de Seguros União Fluminense (71), no biênio 1870-1871; ou pelo Dr. João Emílio Neves Gonzaga, médico perito por dois anos (1862-1863), e que chegaria a trabalhar para a Companhia de Seguros Mútuos União (99) na década seguinte (1875-1876). Com base na avaliação do valor dos escravos é que os prêmios seriam calculados, sendo que poderiam ser acrescidos de um percentual extra quando seus proprietários os segurassem contra os riscos da navegação; nesses casos, teriam de ser levadas em consideração "a duração das viagens, a perda total do navio, e todas as circunstâncias, que poderão alterar a equitativa vantagem do seguro para todos os sócios" (art. 28, Novos Estatutos).

A sobrevivência de cada escravo segurado seria o grande interesse desta companhia, e também o de todas as demais seguradoras que chegaram a operar sobre esses mesmos riscos. A vida escrava seria preciosa, portanto, aos negociantes envolvidos nesse ramo do comércio, mas talvez não estivessem motivados por valores humanitários. Cada morte driblada, somava-se um módico prêmio aos cofres da empresa, porém evitava-se que um montante ainda maior não saísse à indenização. O sucesso dos negócios da Mútua de escravos, assim como o de suas concorrentes na praça comercial do Rio de Janeiro, estivera intimamente dependente do número de perdas conhecidas por seus associados. Para se evitar que tamanhos prejuízos comprometessem sua solvabilidade, e seu crédito no comércio, fora preciso adequar a oferta de seus serviços a um mercado específico, e estipular algumas condições sob as quais ele seria contratado; o que, em última análise, fora o mesmo que exigir dos proprietários um novo tipo de tratamento a ser dispensado ao seu escravo segurado, um novo comportamento que porventura poderia ser algo estranho a uma relação que provavelmente já se estabelecera num momento anterior à subscrição da apólice, e sob códigos nem tanto cordiais. Mas, para se ter ciência dos riscos a que vinha sendo exposto o objeto do seguro, a associação optara por acompanhar de perto alguns

183 BRASIL. Tribunal de Comércio da Corte. Processo n. 2066. Arquivo Nacional do Rio de Janeiro, EI, CODES, Maço 198, 1863. 
momentos dessa relação, o que talvez pudesse explicar sua exigência em ser informada "quando o segurado quiser mandar para a Misericórdia, Hospital ou Casa de Saúde o seu escravo, por causa de moléstia", ou quando o cativo se ausentar do Município Neutro ou do de Niterói por mais de quinze dias (art. 34, Novos Estatutos).

Evitar a perda a todo custo, mas quando a vida não pudera ser mantida, o falecimento do escravo seria atestado pelos médicos da companhia como forma de, no resguardo de seu interesse, certificar "se a morte teve lugar por sevícias ou propinação de veneno por parte do segurado" (art. 29, Novos Estatutos), causas que desobrigariam a Mútua de escravos à indenização, assim como tantas outras expostas na Tabela 6, em comparação às causas que de igual modo isentariam as demais seguradoras da responsabilidade pela perda da propriedade cativa - além de relacionar as idades limites para a contratação de seguros por cada companhia, e o termo máximo estabelecido para a validade da apólice de cada uma delas. Apurar as verdadeiras causas do falecimento do escravo segurado continuaria sendo de grande interesse aos negócios da companhia, ainda que a morte tenha ocorrido em lugares que seus médicos não pudessem chegar. Nesses casos, o próprio segurado deveria providenciar os préstimos de um médico do lugar, que pudesse certificar o que motivara a morte e, sempre que possível, "mencionando na certidão os sinais particulares do cadáver, a fim de julgar-se da identidade do indivíduo, [ou] se existiam sinais de sevícias ao de propinação de veneno (...)" (art. 30, Novos Estatutos). Caso inexistisse qualquer médico local, deveria "proceder a corpo de delito, a fim de verificar-se se a morte teve lugar por outra qualquer causa, que não por sevícias ou propinação de veneno por parte do segurado" (art. 31, Novos Estatutos). Talvez a insistência sobre os maus tratos e o envenenamento denunciasse os principais procedimentos adotados pelos senhores quando estes pretenderam punir seus escravos por qualquer comportamento faltoso. Contudo, se a tortura aparentemente pudesse ser considerada uma forma de castigo, apenas, a repetição que se fazia sobre a prática do envenenamento não deixa dúvidas que ambas as condutas parecem ter sido frequentemente levadas a termo pelos proprietários quando planejaram dar fim à vida de seus escravos. Se estes fossem segurados pela companhia, isentar-se da responsabilidade de indenizar as mortes provocadas por sevícias ou propinação de veneno estaria mais que justificado, pois, ao que tudo indica, fora uma tentativa de escapar ao comportamento danoso dos senhores, à fraude contra o seguro, ao enriquecimento de um à custa de todos. 
Tabela 6: Condições impostas pelas Companhias seguradoras de vida de escravos para a realização dos seguros

\begin{tabular}{|c|c|c|c|c|}
\hline Série & Companhia & $\begin{array}{l}\text { Faixa etária } \\
\text { segurada }\end{array}$ & $\begin{array}{l}\text { Prazo máximo para } \\
\text { renovação do } \\
\text { seguro }\end{array}$ & $\begin{array}{l}\text { Limites à responsabilidade da Companhia quanto às causas da morte } \\
\qquad \text { dos escravos }\end{array}$ \\
\hline $1(19)$ & $\begin{array}{l}\text { Companhia de Seguros } \\
\text { sobre a Vida dos } \\
\text { Escravos Prosperidade }\end{array}$ & - & - & - \\
\hline $2(30)$ & $\begin{array}{l}\text { Companhia de Seguros } \\
\text { Previdência }\end{array}$ & - 12 a 45 anos. & - 1 ano. & $\begin{array}{l}\text { - "A Companhia não responde por morte resultando de sevícias, suicídio, } \\
\text { assassinato, envenenamento, incêndio, desastre ou qualquer outra coisa } \\
\text { que não seja a morte natural” (art. } 4^{\circ} \text {, Estatutos aprovados pelo Decreto no } \\
1.415 \text {, de } 5 \text { de agosto de 1854). }\end{array}$ \\
\hline $3(39)$ & $\begin{array}{l}\text { Companhia de Seguros } \\
\text { Tranquilidade }\end{array}$ & - 10 a 60 anos. & - 1 ano. & $\begin{array}{l}\text { - "No seguro de escravos é condição essencial estes serem vacinados, e a } \\
\text { companhia só deixará de ser responsável por morte proveniente de sevícias } \\
\text { ou suicídio, quando este for originado por ato forçado, castigo bárbaro ou } \\
\text { tortura por parte do segurado" (art. } 4^{\circ}, \text { Estatutos aprovados pelo Decreto n } \\
1.669 \text {, de } 7 \text { de novembro de } 1855) \text {. }\end{array}$ \\
\hline $4(42)$ & $\begin{array}{l}\text { Companhia Mútua de } \\
\text { Seguros de vida de } \\
\text { escravos }\end{array}$ & -10 a 70 anos. & $\begin{array}{l}-1 \text { ano (Estatutos, } \\
1858) \text {. } \\
-1 \text { ano: prazo } \\
\text { mínimo (Novos } \\
\text { Estatutos, 1861). }\end{array}$ & $\begin{array}{l}\text { - "A Companhia se responsabiliza por qualquer gênero de morte, menos a } \\
\text { que resultar de sevícias, ou suicídio, quando este for originado por ato } \\
\text { forçado, castigo bárbaro, ou tortura por parte do segurado" (art. } 22 \text {, } \\
\text { Estatutos aprovados pelo Decreto n }{ }^{\circ} 2.078 \text {, de } 16 \text { de janeiro de } 1858 \text {; Art. } \\
\text { 27, Novos Estatutos aprovados pelo Decreto n } \text { n }^{\circ} .856 \text {, de } 7 \text { de dezembro de } \\
\text { 1861). }\end{array}$ \\
\hline $5(44)$ & $\begin{array}{l}\text { Companhia de Seguros } \\
\text { Marítimos e Terrestres } \\
\text { Feliz Lembrançal } \\
\text { Companhia Geral de } \\
\text { Seguros União }\end{array}$ & $\begin{array}{l}\text { - } 4 \text { a } 70 \text { anos } \\
\text { (Almanak } \\
\text { Laemmert: } \\
\text { 1858-1861). } \\
\text { - } 4 \text { a } 60 \text { anos } \\
\text { (Almanak } \\
\text { laemmert: } \\
\text { 1862-1873). } \\
\text { - } 4 \text { a } 65 \text { anos }\end{array}$ & - 1 ano. & $\begin{array}{l}\text { - "A Companhia toma a si o risco de morte de escravos de ambos os sexos, } \\
\text { contanto que não proceda de maus tratos, ou sevícias de seus Senhores, ou } \\
\text { suicídio que se reconheça por causa de maus tratos, ainda mesmo por parte } \\
\text { da Autoridade" (art. } 1^{\circ} \text {, Apólice, Condições especiais do seguro de } \\
\text { escravos. Cf. Anexos). } \\
\text { - "O Seguro é feito sobre a presunção de que o escravo goza de um estado } \\
\text { ordinário de saúde: por consequência, o Seguro deve declarar, debaixo de } \\
\text { juramento, se julga o escravo ou escravos a segurar em estado de saúde, ou } \\
\text { se sabe que alguma doença oculta o compromete" (art. } 3^{\circ}, \text { idem). }\end{array}$ \\
\hline
\end{tabular}




\begin{tabular}{|c|c|c|c|c|}
\hline & & (Apólice). & & \\
\hline $6(52)$ & $\begin{array}{l}\text { Companhia de Seguros } \\
\text { Util-Previdência }\end{array}$ & 10 a 50 anos. & -1 ano. & - \\
\hline $7(71)$ & $\begin{array}{l}\text { Companhia de Seguros } \\
\text { União Fluminense }\end{array}$ & $\begin{array}{l}-10 \text { a } 50 \text { anos } \\
\text { (Almanak } \\
\text { Laemmert: } \\
\text { 1871-1872) } \\
\end{array}$ & -1 ano. & $\begin{array}{l}\text { - "A companhia toma a si o risco de morte do escravo seguro, menos quando } \\
\text { esta resultar de suicídio ou de sevícias, castigo bárbaro, ou tortura dos } \\
\text { respectivos senhores, ou mesmo da autoridade" (Art. 13, Estatutos } \\
\text { aprovados pelo Decreto } n^{\circ} 4.513 \text {, de } 27 \text { de abril de 1870). }\end{array}$ \\
\hline $8(77)$ & $\begin{array}{l}\text { Companhia de Seguros } \\
\text { Perseverança }\end{array}$ & -10 a 60 anos. & -1 ano. & $\begin{array}{l}\text { - "A Companhia toma a si o risco de morte do escravo segurado, menos } \\
\text { quando esta resultar de suicídio ou sevícias, castigo bárbaro ou tortura" } \\
\text { (Art. 19, Estatutos aprovados pelo Decreto n }{ }^{\circ} 4.829 \text {, de } 23 \text { de novembro de } \\
\text { 1871). }\end{array}$ \\
\hline $9(98)$ & $\begin{array}{l}\text { Companhia } \\
\text { Garantidora de Vidas }\end{array}$ & - & $\begin{array}{l}-1,2,3,4 \text { ou } 5 \text { anos } \\
\text { (1 ou mais anos). } \\
\text { (Almanak Laemmert, } \\
1877, \text { p. } 570)\end{array}$ & $\begin{array}{l}\text { - "Quando a morte resultar de suicídio, maus tratos ou sevícias, a Companhia } \\
\text { fica absolutamente livre do risco contraído" (Almanak Laemmert, 1877, p. } \\
\text { 570). }\end{array}$ \\
\hline $10(99)$ & $\begin{array}{l}\text { Companhia de Seguros } \\
\text { Mútuos União }\end{array}$ & -5 a 55 anos. & - & $\begin{array}{l}\text { - “A Associação não indenizará nos casos seguintes: } \\
\text { "Suicídio do escravo ou morte posterior em consequiência de tentativa de } \\
\text { suicídio. } \\
\text { "Morte do escravo, estando fugido ou no ato da captura ou em } \\
\text { consequência de feridas recebidas no ato da captura. } \\
\text { "Morte do escravo em conseqüência de mau trato. } \\
\text { "Quando a ação de liberdade por arbitramento de valor tenha ocorrido à } \\
\text { revelia do proprietário" (Art. 12, Estatutos aprovados pelo Decreto no } \\
6.058 \text {, de } 14 \text { de dezembro de 1875) }\end{array}$ \\
\hline $\begin{array}{l}11 \\
(107)\end{array}$ & A Equitativa Brasileira & - & -3 anos. & - \\
\hline
\end{tabular}

Fonte: Fonte: Quadro Companhias de Seguros em funcionamento na Província do Rio de Janeiro (1808-1889), cf. Anexo 2; Coleção das Leis do Império do Brasil (18081889). 
Todas essas regras que condicionaram as contratações da Mútua de escravos não valeriam apenas para as subscrições das apólices que seguraram os proprietários dos escravos Ezequiel e Abel, contra os riscos de perdê-los. Tampouco poderiam ser notadas nos seguros realizados somente debaixo da assinatura de seus diretores e gerentes. Em geral, muitas dessas cláusulas constariam dos Estatutos, ou das apólices, de muitas companhias dedicadas a garantir os prejuízos advindos da morte de escravos, e acabariam mesmo por representar a maneira como essas seguradoras negociariam na praça comercial da província do Rio de Janeiro. Marcariam o compasso de um negócio, enfim, que apesar de não ter sido intensamente procurado, como não o fora nos Estados Unidos, se ajustava a um mercado estabelecido sobre a região Sudeste, que abrigava uma das maiores concentrações da população escrava no país, empregada nas fazendas de café, ou às voltas da sobrevivência nos meios urbanos ${ }^{184}$.

Invariavelmente as companhias só se propunham a segurar as vidas que fossem examinadas por médicos de sua confiança. No escritório da companhia, ou no domicílio do candidato, os próprios doutores estimariam o valor dos escravos, ou quem o faria, como previra a Feliz Lembrança em sua apólice, seria a Diretoria da seguradora, ao considerarem a idade, a profissão, e as condições de saúde depois de "ouvido o parecer dos Médicos no exame sanitário." (art. $7^{\circ}$, das Condições especiais do seguro de escravos) $)^{185}$.

${ }^{184}$ Cf. SAVITT, Todd L., op. cit., p. 585=586; MELLO, Pedro Carvalho de, Aspectos econômicos da organização do trabalho da economia cafeeira do Rio de Janeiro, 1850-88, p. 32; 61-63.

${ }^{185} \mathrm{Um}$ dos médicos que prestavam seus serviços à Companhia de Seguros Marítimos e Terrestres Feliz Lembrança (44) fora o Dr. Antonio Gonçalves de Araújo Leitão, que por aí permaneceria durante os anos de 1858 a 1869. Dois anos depois, em 1871, ele ocuparia o cargo de Suplente de Diretor da Companhia Brasileira de seguros sobre a vida/ Companhia Brasileira de Seguros Gerais O Palladio (76). Outro médico que também participaria dos negócios da Feliz Lembrança foi o Dr. José Pereira do Rego, presente no biênio 1858 e 1859. José Pereira Rego (Barão de Lavradio, em 1874) nasceu no dia 24 de agosto de 1816 na cidade do Rio de Janeiro, e aí se formou médico pela Faculdade de Medicina, em 1838. Mesmo tendo recusado o convite do governo para ocupar o cargo de lente substituto da Faculdade de Medicina do Rio de Janeiro, em 1855, foi constantemente consultado no que dizia respeito aos cursos médicos. Foi Presidente da Academia Imperial de Medicina do Rio de Janeiro durante os anos 1855-1857 e 1864-1883. Presidiu a Junta Central de Higiene Pública (1864-1881), órgão subordinado ao Ministério do Império, e encarregado do esclarecimento do governo imperial sobre os assuntos relacionados à saúde pública; foi Inspetor da Saúde do Porto entre 1865 e 1881, e Inspetor Geral do Instituto Vacínico no período 1873-1881. Chegou a ser eleito Vereador da Câmara Municipal, e nomeado Subdelegado de Polícia. Faleceu no dia 22 de novembro de 1892, na cidade do Rio de Janeiro, porém deixando sua contribuição à literatura médica. Dentre outras obras, publicou alguns estudos sobre o estado sanitário do Rio de Janeiro nos idos do século XIX: Algumas reflexões sobre o acréscimo progressivo da mortalidade no Rio de Janeiro (1850-1851); História e descrição da febre amarela epidêmica que grassou no Rio de Janeiro em 1850 (1851); Esboço histórico das epidemias que têm grassado na cidade do Rio de Janeiro desde 1830 até 1870 (dez. 1871 e jan. 1872); Memória histórica das epidemias de febre amarela e cholera-morbus que têm reinado no Brasil (1873); Estudo sobre as epidemias que têm grassado na cidade do Rio de Janeiro desde 1871 até 1878; Estudo das epidemias que têm grassado nesta corte de 1871 até 1880, seguido de uma apreciação geral do movimento sanitário de 1830 a 1880 ; 
Os escravos que certamente seriam aprovados para o seguro seriam aqueles que gozassem de boa saúde, dentro dos quadros esperados, mas o que quer que isso significasse, talvez a Companhia de Seguros Mútuos União (99) explicara, e ia além: seus administradores recusariam qualquer proposta de seguro sobre a vida de escravos que porventura sofressem de "moléstias crônicas ou que, por seu estado físico, se achem impossibilitados de trabalhar, e finalmente os que respondam a processo criminal ou cumpram sentença". (art. $30, \S 6^{\circ}$, Estatutos $\left.^{186}\right)$. Mas, negócio era negócio, e algumas seguradoras como a Feliz Lembrança e a Companhia Garantidora de Vidas (98) abriram exceções para que se confirmassem os seguros sobre a vida de escravos "com alguma indisposição passageira e que não afete órgãos essenciais à vida" ${ }^{187}$, desde que em troca do pagamento de um prêmio mais elevado, e se de acordo com o parecer dos médicos da companhia.

$\mathrm{O}$ valor do prêmio de igual modo seria elevado se os escravos fossem chamados a compor a tripulação de um navio, exercessem certas profissões, ou fossem empregados em trabalhos que muito provavelmente viriam a lhes causar danos à saúde no decorrer do tempo. A associação mútua União, por exemplo, ou desaprovaria ou cobraria um prêmio adicional aos seguros feitos sobre os escravos de "profissões perigosas à vida" (art. 30, § 14, Estatutos); para os “empregados em serviços nas cidades" o valor já estaria estipulado: o prêmio adicional seria de $0,5 \%$ (art. 30, § 13, Estatutos). A Perseverança elevaria sua recompensa caso aceitasse subscrever uma apólice cujo escravo segurado trabalhasse como "foguista, padeiro, canoeiro, marinheiro, carpinteiro, pedreiro, batedor de açúcar e de doce." (art. 20, Estatutos ${ }^{188}$ ). E para os "foguistas, padeiros, empregados em fundições, catraieiros, etc." (art. $4^{\circ}$, das Condições especiais do seguro de escravos, arroladas na apólice) a Feliz Lembrança somaria 1\% sobre o valor do prêmio, mesmo montante que a Garantidora de Vidas estabelecera para os seguros de escravos aplicados em profissões danosas. De qualquer modo, com ou sem o acréscimo dos prêmios, algumas companhias como a própria Perseverança e a União Fluminense, não se arriscariam a contratar seguros cujos valores ultrapassassem $1.500 \$ 000$ (um conto e quinhentos mil réis); ou como a

Plano dos melhoramentos necessários para preservar a cidade do Rio de Janeiro das epidemias reinantes (1878); No mesmo ano de 1878, veio a lume os Apontamentos sobre a mortalidade da cidade do Rio de Janeiro, particularmente das crianças e sobre o movimento de sua população no primeiro quatriênio depois do recenseamento feito em 1872. Cf. BLAKE, Augusto Victorino Alves Sacramento, op. cit., vol. 5, p. 126130; Dicionário histórico-biográfico das Ciências da Saúde no Brasil (1832-1930), ver entrada "Rego, José Pereira".

${ }^{186}$ Cf. Decreto ${ }^{\circ}$ 6.058 de 14 de dezembro de 1875.

${ }^{187}$ Cf. Almanak administrativo, mercantil e industrial do Rio de Janeiro - Almanak Laemmert, 1877, p. 570. Trata-se de uma propaganda anunciada pela Garantidora de Vidas.

${ }^{188}$ Cf. Decreto no 4.829 de 23 de novembro de 1871. 
União, que só garantiria a indenização de uma quantia correspondente a quatro quintos do valor do escravo avaliado por um de seus empregados, nomeado pela Direção Geral.

Além de todas essas condições, as companhias frequentemente exigiram dos proprietários por elas segurados que tão logo lhes comunicassem a ocorrência de qualquer evento que pudesse comprometer a saúde ou a vida do escravo. Toda internação, seja em hospitais ou em casas de saúde, públicos ou particulares; qualquer confinamento em casas de detenção; ou mesmo a saída temporária (por mais de 15, ou 30 dias) da área em que estivessem circunscritos os negócios de uma dada seguradora; sobre todos esses acontecimentos seria razoável um mínimo de acompanhamento por parte dos médicos das companhias que, como se sabe, em muitos casos seriam os empregados responsáveis por representá-las nos seus interesses de manter os vislumbres da morte à distância dos escravos segurados. Talvez se possa dizer ter sido esta a razão de tamanha preocupação por parte dos incorporadores da Companhia de Seguros Perseverança, ao estabelecerem que

\footnotetext{
fica o segurado obrigado, logo que o escravo adoecer, a prestar-lhe todos os socorros médicos e logo participar por escrito à Diretoria, a fim de ser visitado pelo médico que ela designar, se assim o julgar necessário, podendo o escravo doente ser removido para lugar mais conveniente, se a localidade em que se estiver tratando não oferecer garantias de boas condições higiênicas e de bom tratamento: por conta do segurado correrão as despesas com o mesmo tratamento. (art. 23, Estatutos)
}

Mas, se com todos esses cuidados mesmo assim o escravo sucumbir à doença ou, se for o caso, aos ferimentos, os próximos procedimentos das seguradoras caminhariam no sentido do que estipulara a Companhia Mútua de Seguros de vida de escravos. Um dos médicos das companhias seria designado a ir até o local do falecimento e certificar a identidade e as verdadeiras causas da morte do indivíduo, como forma de se evitar as fraudes que poderiam ser cometidas pelos segurados. Nesse sentido foi que a Feliz Lembrança estipulou a todo proprietário com quem havia contratado que "ocultar, dissimular, ou de qualquer modo alterar a verdade, ou apresentar quaisquer documentos falsos" (art. $6^{\circ}$, das Condições especiais do seguro de escravos, arroladas na apólice), quando da comunicação do sinistro, ocasionaria o decaimento de seus direitos à reclamação da indenização; assim como já havia previsto em artigo anterior que "Toda reticência, toda a falsa declaração da parte do Segurado, ou falta de participação em caso de agravação de risco, anula o contrato." (art. $2^{\circ}$, das Condições gerais do seguro, arroladas na apólice). A União Fluminense (art. 14, Estatutos) e a Perseverança (art. 20, Estatutos) 
de igual modo entenderam que se no ato da contratação dos seguros o proprietário esconder ou não declarar a verdadeira profissão (ou ocupação) de seu escravo, esta reticência por si só “vicia e anula a apólice em todos os seus efeitos”. Se essas ou outras cláusulas pudessem gerar dúvidas e desentendimentos entre os contratantes, em geral as companhias estabeleceram que qualquer contenda fosse decidida por árbitros, cada um nomeado por uma das partes interessadas. Em caso de empate, um terceiro poderia ser indicado pelo Tribunal do Comércio, ou tirado à sorte pela companhia e pelo segurado. Um ou outro deveria acatar um dos entendimentos anteriores, e de seu arbitramento se poderia apelar "para o Juízo competente", conforme ia na apólice da Feliz Lembrança (art. 5, das Condições gerais do seguro; e arts. 33 a 35, Estatutos de 1858); ou não, conforme os Estatutos da União Fluminense (art. 44), da Companhia de Seguros Mútuos União (art. 32), e da Equitativa Brasileira (art. 24).

De qualquer modo, uma vez confirmado o direito à indenização, os segurados deveriam reclamá-la dentro de certos prazos determinados pelas seguradoras que, em geral, seriam de um ano contado a partir da ocorrência do sinistro, ou da notícia que informou seu acontecimento. No entanto, a quantia previamente combinada quando da contratação do seguro poderia não ser recebida em sua integralidade pelos proprietários, pois ainda estaria a mercê de reduções a depender das circunstâncias que envolveram a morte de seus escravos. Normalmente, se o falecimento de um escravo fosse decorrente de hérnia, por exemplo, a União Fluminense e a Perseverança reduziriam 25\% do valor da indenização; mesma porcentagem caso uma escrava morresse em consequência do parto. A morte de uma escrava ao dar à luz também fora motivo para as companhias Feliz Lembrança e a Garantidora de Vidas diminuírem, cada uma, $200 \$ 000$ (duzentos mil réis) do montante a ser indenizado. A primeira ainda consideraria abater $30 \%$ se o escravo sucumbisse à cólera; mesmo percentual que a segunda descontaria caso a morte decorresse de combate ou epidemia.

Contudo, pelo menos duas dessas companhias que estiveram em funcionamento durante a década de 1870 fariam constar outros termos em suas apólices que de igual forma poderiam repercutir na diminuição da quantia originalmente acordada a ser paga como indenização aos seus segurados. Ambas, Companhia de Seguros Mútuos União (art. $30, \S 9^{\circ}$, Estatutos) e a Equitativa Brasileira (art. 19, $\S 7^{\circ}$ e $8^{\circ}$, Estatutos), estipularam um prazo de apenas 15 dias para que os proprietários lhes comunicassem a morte dos escravos sob pena de perderem $20 \%$ do montante a que teriam direito. Direito, aliás, que correria o 
risco de decair caso esta comunicação lhes faltassem decorridos três meses do dito falecimento. Afora estas condições, algumas das companhias que sobreviveram ao fim da Guerra contra o Paraguai, e que alcançaram ao menos o crepúsculo do novo decênio que amanhecia, chegaram a operar seus negócios sobre outras bases que não conhecidas pelas seguradoras que cessaram suas atividades no mais tardar em meados da década de 1860 . Foram bases mais sólidas, ao que parece, e que sustentariam uma estrutura coerentemente aos novos riscos que afetariam a propriedade escrava nos idos da década de 1870 .

Mesmo com a promulgação da Lei do Ventre Livre logo em 1871, que declarara que ninguém mais nasceria escravo no Brasil, parece que os proprietários não acreditaram que a escravidão já estivesse com seus dias contados. Os preços dos cativos seriam valorizados pelo menos até 1881, e sua força de trabalho continuaria a ser procurada para o emprego nas plantações de café, ou para os ganhos que poderiam gerar quando aplicados em certas atividades urbanas. Segundo Mello, em 1873 o aluguel mensal médio de um escravo do sexo masculino, cuja idade estivesse entre os 20 e 29 anos, e que fosse destinado aos cafezais, giraria em torno dos $24 \$ 300$ (vinte e quatro mil e trezentos réis), o que, ao final de um ano, corresponderia a 291\$600 (duzentos e noventa e um mil e seiscentos réis), brutos. Feitas as devidas deduções, o proprietário que alugasse seu escravo naquele ano provavelmente receberia ao fim de doze meses um montante algo às voltas de $190 \$ 400$ (cento e noventa mil e quatrocentos réis) e $179 \$ 200$ (cento e setenta e nove mil e duzentos réis) ${ }^{189}$. Esses valores, por si só, careceriam de sentido se não servissem ao

\footnotetext{
${ }^{189}$ Pedro Carvalho de Mello pesquisou os inventários de fazendeiros de café estabelecidos nos municípios do Rio de Janeiro e de Vassouras durante o século XIX, e também anúncios do Jornal do Comércio, cartas de libertação de escravos, e hipotecas das fazendas de café mencionadas nas atas de gerência do Banco do Brasil e nos anúncios do Jornal. Do total das informações encontradas para o período compreendido entre 1835 e 1887 (foram 11.121 preços de escravos, classificados por sexo e ocupação), Mello fez um recorte sobre os preços correspondentes aos escravos do sexo masculino pertencentes à faixa dos 20 a 29 anos de idade ofertados no período 1870-1887 (foram, ao todo, 441 preços). Por outro lado, no que diz respeito aos preços dos alugueis negociados na cidade do Rio de Janeiro, Mello se valeu principalmente do que fora anunciado nas páginas do Jornal do Comércio. Aí foram oferecidos ao aluguel tanto escravos de ocupações urbanas como os que seriam contratados para o trabalho rural. De todos os anúncios analisados para o período de 1835 a 1888 (foram, no total, 4.829, nos quais se informaram o sexo e a ocupação dos escravos), o autor selecionou 469, todos eles referentes a escravos agrícolas do sexo masculino ofertados durante 1871 a 1888. A Tabela 1: Preço médio e aluguel de escravos (em mil réis), deu conta de organizar todas essas informações referentes tanto ao preço do escravo, quanto ao valor do aluguel a ser pago pelos préstimos de seus serviços, cf. MELLO, Pedro Carvalho de, Aspectos econômicos da organização do trabalho da economia cafeeira do Rio de Janeiro, 1850-88, p. 30-31. O autor chegou ao valor aluguel anual líquido de um escravo contratado mensalmente após deduzir do total mensal os "dias perdidos por doença (5.5\%), custo de propaganda e comissões $(7,5 \%)$, impostos $(3,4 \%)$, custos de procura em termos de dias perdidos na espera de trabalho $(5 \%)$, casa e comida pagos pelo dono durante alguns dias por ano $(7,4 \%)$, despesas médicas $(2,1 \%)$, roupas $(3,8 \%)$ "; a soma de todos esses valores $(34,7 \%)$ seria abatida do montante do aluguel anual bruto. Todas essas deduções também seriam necessárias caso o propósito fosse chegar ao valor do aluguel anual líquido do escravo contratado por diárias. Ibidem, p. 41-42.
} 
cálculo da taxa de retorno que se poderia obter caso se optasse por investir em escravos, tendo-se em vista seu preço, sua idade, e a receita líquida que seria obtida mediante o uso de seu trabalho: durante os três anos compreendidos entre 1870 e 1872, o capital aplicado na escravidão poderia render 13\%, ano a ano; um pouco menos (12\%) entre 1873 e 1875; esta taxa seria elevada a 15\% em 1876, 1877 e 1878; e, no final da década e início da seguinte (1878-1881), o rendimento ficaria estabelecido em $11,5 \%{ }^{190}$. Todos esses números acabam por revelar que o investimento que se fazia em escravos renderia tanto quanto os lucros auferidos de outras aplicações para o capital, pelo menos durante a década de 1870. E com a propriedade escrava relativamente valorizada, talvez fosse de interesse de seus senhores a procura por companhias que se dispusessem a indenizá-los caso a morte abocanhasse parte de seu patrimônio. A morte, ou a liberdade.

Quando os escravos, por seus tutores, por seus advogados, pelos abolicionistas, enfim, passaram a levar aos tribunais a discussão em torno de sua condição, o risco da libertação tornou-se cada vez mais real, e frequente. Pelo menos desde a década de 1860 , quando as ações de liberdade já seriam intentadas para provocar o governo imperial a reconhecer a ilegalidade do estado servil daqueles que conseguissem provar, por todos os meios, terem sido aportados no Brasil após a promulgação da lei de 7 de novembro de 1831. Muito embora essas ações fossem mais disseminadas a partir dos primeiros anos da década de 1880, época que conhecera a tomada de força do movimento abolicionista, e que presenciara um Poder Judiciário mais receptivo à interpretação "radical" da lei de $1831^{191}$; algumas das seguradoras que compartilharam desses momentos, então, logo estipularam condições que as isentassem do pagamento de qualquer indenização. Tal fora o caso da União Fluminense, e também da Perseverança que, em seus Estatutos aprovados cerca de dois meses depois da publicação da Lei do Ventre Livre, estabelecera que "Desde que o escravo ou escrava seguro se libertar ou for libertado, cessa a responsabilidade da companhia, à qual, aliás, pertencerá o prêmio respectivo.” (art. 33).

Mas, pelo contrário, parece que a Lei não geraria em todas as seguradoras o temor que provocou na Perseverança. Alguns anos mais tarde, quando a Companhia de Seguros Mútuos União foi autorizada a funcionar, em dezembro de 1875, dentre os riscos

\footnotetext{
${ }^{190}$ Ibidem, p. 44, cf. "Tabela 4: Taxas internas de retorno no investimento de escravos adultos da roça do sexo masculino, 1870-1881 (mil réis)".

${ }^{191}$ Cf. MAMIGONIAN, Beatriz Gallotti. O Direito de ser africano livre: os escravos e as interpretações da lei de 1831 , p. 145, 151.
} 
garantidos, o da morte do escravo configurar-se-ia apenas como um deles. Ela de igual forma estivera disposta a

\begin{abstract}
segurar contra o risco de prejuízo nas emancipações forçadas, (...), obrigando-se a Associação a pagar aos sócios a diferença entre a quantia pela qual for por sentença, proferida em juízo competente, arbitrado o valor do escravo para libertar-se, na forma do art. $4^{\circ}$ da Lei $n^{\circ} 2040$ de 28 de Setembro de 1871, e a importância do respectivo seguro. (art. $6^{\circ}, \S 2^{\circ}$, Estatutos) ${ }^{192}$
\end{abstract}

Como se vê, de qualquer forma, se pela morte ou se pela liberdade, o valor integral do escravo perdido seria garantido ao seu proprietário segurado. Diferentemente da Equitativa Brasileira, que só contratava contra os riscos de morte, e que exigiria dos senhores a apresentação da certidão de vida e a matrícula especial dentro de três meses "contados do dia em que o contrato tiver sido feito" (art. 19, $\S 6^{\circ}$, Estatutos) - sob pena de uma redução mensal no valor do contrato até que os documentos fossem mostrados, e do risco do escravo falecer durante esse período, por onde "o associado não terá direito à indenização alguma" -; a União viria a propagandear o que talvez fosse uma vantagem que oferecia ao mercado, um chamariz que bem lhe poderia render um aumento na procura pelos seus serviços. Dizia que

O único documento exigido para efetuar-se o seguro é a certidão da matrícula especial, e para reclamar o valor segurado, no fim de cada semestre [Agosto e Fevereiro], a certidão de óbito devidamente reconhecida por tabelião e a baixa da matrícula, ou, em caso de liberdade forçada, as certidões da sentença e a do arbitramento, extraídas dos autos da ação de liberdade. ${ }^{193}$

Os negócios da companhia vinham obtendo sucesso, ao que parece, no correr do segundo lustro da década de 1870 . A chamada que lhe fizera o Almanak Laemmert nas

${ }^{192} \mathrm{O}$ artigo $4^{\circ}$ da Lei $\mathrm{n}^{\mathrm{o}} 2.040$, de 28 de setembro de 1871 previra algumas possibilidades para a ocorrência da alforria:

“Art. $4^{\circ}$ É permitido ao escravo a formação de um pecúlio com o que lhe provier de doações, legados e heranças, e com o que, por consentimento do senhor, obtiver do seu trabalho e economias. O Governo providenciará nos regulamentos sobre a colocação e segurança do mesmo pecúlio.

"§ $1^{\circ}$ Por morte do escravo, metade do seu pecúlio pertencerá ao cônjuge sobrevivente, se o houver, e a outra metade se transmitirá aos seus herdeiros, na forma da lei civil.

"Na falta de herdeiros, o pecúlio será adjudicado ao fundo de emancipação de que trata o art. $3^{\circ}$.

"§ $2^{\circ} \mathrm{O}$ escravo que, por meio de seu pecúlio, obtiver meios para indenização de seu valor, tem direito a alforria. Se a indenização não for fixada por acordo, o será por arbitramento. Nas vendas judiciais ou nos inventários o preço da alforria será o da avaliação.

"§ $3^{\circ}$ É, outrossim, permitido ao escravo, em favor da sua liberdade, contratar com terceiro a prestação de futuros serviços por tempo que não exceda de sete anos, mediante o consentimento do senhor e aprovação do Juiz de Órfãos.

“(...).".

${ }^{193}$ Cf. Almanak administrativo, mercantil e industrial do Rio de Janeiro - Almanak Laemmert, 1877, p. 589. Trata-se de um anúncio que a companhia fez veicular pelo Almanak. 
suas páginas publicadas em 1877 informara que o capital segurado pela União até o fim do ano anterior (1876) perfazia o total de 3.400:000\$000 (três mil e quatrocentos contos de réis). A cifra correspondente às suas contas fechadas ao fim de 1877 seria aumentada para os 4.000\$000:000 (quatro mil contos de réis); e, a do ano sequente, alcançaria os 4.500:000\$000 (quatro mil e quinhentos contos de réis). A última notícia ventilada a respeito da continuidade das operações da Companhia de Seguros Mútuos União data do ano de 1884, trazida pelo Almanak mediante um anúncio informativo dos traços que lhe foram característicos durante a vigência de 1883. Se essa interrupção nas chamadas denunciar, de fato, o encerramento das atividades da União na praça comercial da província do Rio de Janeiro, talvez se possa afirmar tenha sucumbido à pressão abolicionista intensificada, sobretudo, a partir dos primeiros anos da década de 1880, acompanhando uma tendência do mercado, que já não ofereceria tantas garantias aos investimentos em escravos, e da própria sociedade.

Dentre as seguradoras de vida de escravos que haviam contratado suas apólices no mercado carioca vigente durante o século XIX, apenas uma, ao que parece, teve seus negócios afetados pela sobrevinda da Lei Áurea, e assistira à inevitável queda do Império. A Companhia de Seguros Perseverança, fundada pelos negociantes estabelecidos em Campos dos Goytacazes logo após a promulgação da lei que libertava o ventre das escravas, deu de cara às portas da abolição, em 1888; e quando ninguém mais seria considerado escravo no Brasil, se não tivesse encerrado suas atividades antes do 13 de maio, estaria proibida de seguir com essas suas contratações a partir do dia seguinte. 


\section{CONSIDERAÇÕES FINAIS}

A doutrina jurídica produzida durante todo o século XIX classificou os contratos de seguros em basicamente dois ramos: os seguros marítimos, pelos quais os seguradores garantiriam o pagamento de certa quantia em indenização caso os segurados, uma vez adimplentes, fossem prejudicados pela ocorrência de sinistros que acabassem por inutilizar ou destruir as embarcações ou as mercadorias transportadas por mares e rios; e os seguros terrestres, procurados pelos negociantes, proprietários e demais cidadãos preocupados em amenizar os prejuízos decorrentes da superveniência dos riscos inerentes a qualquer empreendimento capitalista (transporte de mercadorias por terra, por exemplo), às propriedades (prédios urbanos, objetos de valor, escravos, etc.), ou ao futuro das famílias, no caso de morte prematura do arrimo.

No que diz respeito a esta última possibilidade, muito embora os seguros contra os riscos de morte de pessoas livres estiveram proibidos de ser contratados durante a vigência do Império do Brasil, posto que aquela sociedade coeva condenara moralmente qualquer tentativa de se colocar a vida de uma pessoa livre sob os ditames das leis do comércio, esta modalidade de seguros - o seguro de vida de pessoas livres, um seguro terrestre, portanto foi, ao que parece, amplamente negociada por inúmeras companhias difundidas pela praça comercial da província do Rio de Janeiro. Porém, revestida por características especiais, que bem poderiam identificá-la a uma espécie particular dentre as modalidades de seguros de vida.

Eram considerados seguros de vida os contratos que talvez hoje possam ser assemelhados aos planos de previdência. Nesses casos, o pagamento de um prêmio anual, por exemplo, poderia garantir ao segurado, ou à sua família, certa quantia em dinheiro a ser recebida numa data previamente estipulada, de uma só vez ou em parcelas; ou um dote, uma herança, etc. As companhias que se dedicaram a realizar esses contratos o fizeram de forma exclusiva ou paralelamente ao seguro de outros riscos, inclusive os riscos de morte dos escravos; mas, de um modo ou de outro, a soma de todas elas correspondeu a uma pequena parcela do total das companhias estabelecidas naquela província.

Para todos os anos compreendidos entre 1808 e 1889 pudemos identificar a presença de 143 companhias de seguros que, ou foram autorizadas a se estabelecer, ou chegaram, de fato, a funcionar naquele mercado. Todas elas foram relacionadas no Quadro 
Companhias de Seguros em funcionamento na Província do Rio de Janeiro (1808-1889) confira o Anexo 2 - e ordenadas pelas datas referentes às primeiras notícias que as fontes consultadas forneceram a respeito de suas respectivas existências. Por ele percebemos que durante todo o período percorrido pela pesquisa, alguns momentos se destacaram por propiciarem o surgimento de uma quantidade maior de companhias quando comparados a outros anos do século. Nesse sentido, a conjuntura da década de 1870 (1871-1880) foi a mais favorável ao setor dos seguros, pois durante esses anos foram notadas a presença de 43 novas seguradoras: 24 seriam nacionais, enquanto outras 19 seriam estrangeiras; o decênio de 1850 (1851-1860), por cujos anos circularam grande quantidade do capital dantes empregado no tráfico transatlântico de escravos, acabou se configurando no segundo momento mais oportuno à incorporação das seguradoras, quaisquer que tivessem sido os riscos contratados: 11 das quais seriam nacionais e, inversamente, a maioria (18) seria estrangeira. Computando-se todo o período (1808-1889), no entanto, o número de companhias nacionais e estrangeiras que participaram da montagem desse mercado estabelecido no Rio de Janeiro apresentou-se bem dividido (cerca de 50\%), mas, por outro lado, dentre as internacionais, pode-se afirmar que havia acentuada diferença quanto às nacionalidades estabelecidas no país. Cerca de um terço (29\%) das companhias estrangeiras que operaram na província seriam britânicas; seguidas pelas alemãs (20\%), e pelas norte-americanas $(8 \%)$. Ainda compuseram esse quadro as companhias espanholas (7\%), as francesas e as italianas (6\% cada), as portuguesas (4\%), as austríacas e as suíças ( $3 \%$ cada), e, por fim, as belgas, as escocesas e as holandesas, cada nacionalidade participando com apenas $1 \%$ do total das seguradoras instaladas sob bandeira internacional.

Contudo, entre uma e outra década, fora somente a partir de meados do século XIX que o mercado segurador conhecido pela praça carioca começou a concentrar um número cada vez maior de companhias. Da mesma forma, fora a partir de meados do século que as companhias de seguros de vida de escravos, pelo que foi averiguado, começaram a oferecer seus serviços aos senhores interessados em resguardar seus respectivos patrimônios contra os prejuízos provocados pela perda de qualquer propriedade cativa, e segurada.

Com exceção da companhia de seguros Prosperidade, cuja única notícia de que dispomos e que informa algo a respeito de sua existência data de 1845 , todas as demais seguradoras de vida de escravos obtiveram autorização para funcionar ou foram 
estabelecidas, de fato, nas décadas de 1850 e de 1870, coincidência ou não, as mesmas épocas em que a praça comercial do Rio de Janeiro estivera propícia ao surgimento de uma quantidade razoável de seguradoras; e as mesmas épocas em que a concentração de companhias em atividade, dedicadas ao seguro de vida de escravos, coincidiu aos movimentos conhecidos pelas companhias nacionais que contrataram os seguros terrestres, indiscriminadamente. Foi também a partir de meados da década de 1840 que algumas seguradoras norte-americanas começaram a subscrever apólices contra os riscos e os prejuízos ocasionados pela morte de escravos, grande parte delas negociaram nos estados sulistas, escravistas.

Em geral, as companhias brasileiras que contrataram sobre a vida dos escravos, tantos as que tiveram seus Estatutos aprovados pelo governo imperial nos idos da década de 1850, como as que foram autorizadas a funcionar a partir dos anos de 1870; todas elas apresentaram muitas semelhanças no modo como condicionaram a oferta de seus negócios na província do Rio de Janeiro. Umas e outras somente firmariam contratos que garantissem a vida de escravos com idade a partir de 4 ou 5 anos - sendo que algumas não se arriscariam com os menores de 10 ou 12 anos -, mas não superior a 45, 50, 55, 60, 65 ou 70 anos. A maioria delas não tomou seguros por prazo superior a um ano, devendo o segurado, se fosse de seu interesse, renovar o contrato. E quase todas elas, pelo que se pode constatar, não pagariam as indenizações nos casos em que a morte fosse provocada pelos próprios proprietários, seja decorrente dos maus tratos tão frequentes nas relações mantidas entre senhor e escravo, ou ocasionada por envenenamento. Essa modalidade de seguros, como é sabido, foi oferecida para resguardar o patrimônio dos proprietários contra os prejuízos provocados pela morte de qualquer um de seus escravos segurados, contra riscos bem conhecidos e que poderiam lhes tirar a vida; e não, como bem poderia acontecer, para enriquecer os senhores que tentassem subverter o propósito do contrato, fraudando o seguro. Foram cuidados tomados por quase todas as companhias, fossem elas sociedades anônimas, como o fora a maioria, ou associações mútuas, em que o segurado era, ao mesmo tempo, segurador.

A análise dos Estatutos de cada uma delas, que estiveram em sintonia com os Estatutos aprovados pelo governo imperial quando da autorização concedida para o funcionamento das demais companhias coevas, acabam por denunciar algo além das condições impostas para a realização de seus negócios. Todos eles revelam a organização diretiva e administrativa escolhida pelas empresas como o meio mais eficiente para a 
realização de suas atividades e a persecução de seus objetivos. Por conseguinte, de todos eles emergem as estruturas de poder sob as quais seria governada cada seguradora e, portanto, antecipam algumas das situações conflituosas que porventura estariam envolvidos todos ou parte de seus membros. Tal fora o caso da Companhia de Seguros Previdência incorporada em 1854. Muitas das prerrogativas conferidas aos seus gerentes Carlos Le Blon e Estevâo Bernard -, por serem também os fundadores da seguradora juntamente com G. Oelsner Monmerqué, acabaram por esbarrar nos interesses de muitos acionistas.

Os Estatutos das companhias seguradoras também revelam algumas das regras regulamentadoras do relacionamento mantido entre o Estado Imperial e as sociedades mercantis: anônimas e mútuas. A estipulação da realização do capital necessário para se dar início às atividades; as responsabilidades dos sócios ou acionistas tanto para a subscrição das ações em tempos de estabilidade financeira como em tempos de déficit; os direitos e deveres de cada um deles, e também dos diretores, gerentes, conselheiros, etc.; o modo de resolução dos conflitos surgidos entre os administradores das seguradoras e os acionistas ou associados: por árbitros ou, em alguns casos, com recurso para o Tribunal do Comércio; o procedimento a cumprir pelos representantes das companhias nos casos em que a assembleia dos acionistas, ou dos sócios, decidiram pela alteração de determinadas cláusulas dos Estatutos; etc. Se estudados em série, e compreendidos dentro de um período razoável de tempo, talvez estes Estatutos das companhias seguradoras poderiam retratar os diferentes momentos vivenciados pelo setor dos seguros em meio às constantes transformações sofridas pelo mercado carioca de meados do século XIX, um mercado que começaria a se reestruturar, e portanto a conhecer novas formas de investimentos, uma vez cessada a importação de africanos cativos ao Brasil. 


\section{REFERÊNCIAS}

\section{Fontes consultadas em meio impresso}

BORGES, José Ferreira. Commentarios sobre a legislação portugueza acerca de seguros marítimos. Lisboa: Typographia da Sociedade Propagadora dos Conhecimentos Uteis, 1841.

Diccionário Jurídico-Commercial. Pernambuco: Typographia de Santos \& Companhia, 1843.

BRASIL. Conselho de Estado. Seção de Fazenda. Imperiaes Resoluções do Conselho de Estado na Seção de Fazenda: desde o ano em que começou a funcionar o mesmo Conselho até o de 1865. Annos de 1842 a 1844. Vol. 1. Rio de Janeiro: Typographia Nacional, 1867.

. Imperiaes Resoluções do Conselho de Estado na Seção de Fazenda: desde o ano em que começou a funcionar o mesmo Conselho até o de 1865. Annos de 1845 a 1849. Vol. 2. Rio de Janeiro: Typographia Nacional, 1867.

Imperiaes Resoluções do Conselho de Estado na Seção de Fazenda: desde o ano em que começou a funcionar o mesmo Conselho até o presente. Annos de 1850 a 1855. Vol. 3. Rio de Janeiro: Typographia Nacional, 1870.

Imperiaes Resoluções do Conselho de Estado na Seção de Fazenda: desde o ano em que começou a funcionar o mesmo Conselho até o presente. Annos de 1856 a 1860. Vol. 4. Rio de Janeiro: Typographia Nacional, 1871.

Imperiaes Resoluções do Conselho de Estado na Seção de Fazenda: desde o ano em que começou a funcionar o mesmo Conselho até o presente. Annos de 1861 a 1865. Vol. 5. Rio de Janeiro: Typographia Nacional, 1871. 
Imperiaes Resoluções do Conselho de Estado na Seção de Fazenda: desde o ano em que começou a funcionar o mesmo Conselho até o presente. Annos de 1866 a 1870. Vol. 6. Rio de Janeiro: Typographia Nacional, 1871.

Imperiaes Resoluções do Conselho de Estado na Seção de Fazenda: desde o ano em que começou a funcionar o mesmo Conselho até o presente. Annos de 1871 a 1873. Vol. 7. Rio de Janeiro: Typographia Nacional, 1874.

Imperiaes Resoluções do Conselho de Estado na Seção de Fazenda: desde o ano em que começou a funcionar o mesmo Conselho até o presente. Annos de 1874 a 1876. Vol. 8. Rio de Janeiro: Typographia Nacional, 1876.

Imperiaes Resoluções do Conselho de Estado na Seção de Fazenda: desde o ano em que começou a funcionar o mesmo Conselho até o presente. Annos de 1877 a 1879. Vol. 9. Rio de Janeiro: Typographia Nacional, 1879.

Imperiaes Resoluções do Conselho de Estado na Seção de Fazenda: desde o ano em que começou a funcionar o mesmo Conselho até o presente. Annos de 1880 a 1882. Vol. 10. Rio de Janeiro: Typographia Nacional, 1884.

Imperiaes Resoluções do Conselho de Estado na Seção de Fazenda: desde o ano em que começou a funcionar o mesmo Conselho até o presente. Annos de 1883 a 1885. Vol. 11. Rio de Janeiro: Typographia Nacional, 1886.

Imperiaes Resoluções do Conselho de Estado na Seção de Fazenda: desde o ano em que começou a funcionar o mesmo Conselho até o presente. Annos de 1886 a 1889. Vols. 12 e 13. Rio de Janeiro: Typographia Nacional, 1890.

BRASIL. Juízo de Paz da Freguezia da Glória. Processo n. 3025. Arquivo Nacional do Rio de Janeiro, ZO, CODES, Maço 845, 1866.

BRASIL. Ministério do Trabalho, Indústria e Comércio. Sociedades Mercantis autorizadas a funcionar no Brasil (1808-1946). Rio de Janeiro; Imprensa Nacional, 1947. 
BRASIL. Ministério da Indústria e do Comércio. Instituto de Resseguros do Brasil.

Coletânea da legislação brasileira de seguros (De 29 de abril de 1828 a 1 de abril de 1947). Publicação n. 9 do IRB. $2^{\text {a }}$ ed. [Rio de Janeiro]: [Imprensa Nacional], 1949.

BRASIL. Ministério da Indústria e do Comércio. Instituto de Resseguros do Brasil. Ementário da legislação brasileira de seguros (1808 a 1973). [Rio de Janeiro]: [s.n], s.d.

BRASIL. Ministério da Indústria e do Comércio. Instituto de Resseguros do Brasil. Legislação brasileira de seguros (atualizada até 31.07.93). Publicação n. ${ }^{\circ} 80$ do IRB. s.l: [s.n], 1993.

BRASIL. Tribunal de Comércio da Corte. Processo n. 2066. Arquivo Nacional do Rio de Janeiro, EI, CODES, Maço 198, 1863.

CAROATA, José Próspero Jeová da Silva. Imperiaes resoluções tomadas sobre consultas da secção de justiça do conselho de estado. 2 vols. Rio de Janeiro: B. L. Garnier, 1884.

COSTA, José da Silva. Seguros marítimos e terrestres. Rio de Janeiro: H. Laemmert \& C., 1883.

O Direito: revista de legislação, doutrina e jurisprudência. Rio de Janeiro, 1873-1889.

LISBOA, José da Silva, Visconde de Cairu. Princípios de direito mercantil e leis de marinha. $6^{\text {a }}$ ed. Tomos I e II. Rio de Janeiro: Typographia Acadêmica, 1874.

Reflexões sobre o comércio de seguros. Rio de Janeiro: Impressão Régia, 1810. In: LISBOA, José da Silva, visconde de Cairu. Princípios de direito mercantil e leis de marinha. $6^{\text {a }}$ ed. Tomos I e II. Rio de Janeiro: Typographia Acadêmica, 1874, p. 957-972.

MAFRA, Manoel da Silva. Jurisprudencia dos tribunaes (compiladas dos accordãos dos tribunaes superiores publicadas desde 1861). 3 vols. Rio de Janeiro/ Paris: B. L. Garnier Livreiro-Editor/ A Durand e Pedone Lauriel, 1868. 
NEVARES, Nicanor G. de. Seguros sobre la vida. Dissertacion para optar al grado de doctor en jurisprudencia. Buenos Aires: Imp. de M. Bedma, 1886.

PINHEIRO, Francisco Baptista Marques. Jurisprudencia Commercial. Rio de Janeiro: Typ. do Apostolo, 1870.

Relatorio da Directoria da Imperial Companhia de Seguro Mutuo Contra Fogo para ser presente à Assembléa Geral dos Srs. Socios no dia 26 de Junho de 1886. Rio de Janeiro: s. n., 1886.

RIBEIRO, Annibal André. Breves observações sobre as anotações do Dr. Salustiano Orlando de Araújo Costa ao Código Comercial do Império do Brasil. Rio de Janeiro; Eduardo \& Henrique Laemmert, 1871.

SALUSTIANO ORLANDO de Araújo Costa. Código Comercial do Império do Brasil. $3^{\mathrm{a}}$ ed. Rio de Janeiro: Eduardo \& Henrique Laemmert, 1878.

. Código Comercial do Brazil. $5^{\mathrm{a}}$ ed. Rio de Janeiro: Laemmert, 1896.

SANTARÉM, Pedro de. Tratactus de assecurationibus et sponsionibus (1552). Lisboa: Grêmio dos Seguradores, 1971.

SOUSA PINTO, A. de. Diccionario da Legislação Commercial Brazileira. Tomo I. Lisboa: Tavares Cardoso \& Irmão, 1892.

Diccionario da Legislação Commercial Brazileira. Tomo II. Lisboa: Tavares Cardoso \& Irmão, 1893. 


\section{Fontes consultadas em meio digital}

Almanak administrativo, mercantil e industrial do Rio de Janeiro - Almanak Laemmert. 1844-1889. Disponível em: <http://www.crl.edu/pt-br/brazil/almanak>. Acesso em: 15 jun 2010.

BRASIL. Poder Legislativo. Câmara dos Deputados. Coleção das Leis do Império.

Disponível em: <http://www2.camara.gov.br/legislacao/publicacoes/doimperio >. Acesso em: 15 jun 2009 .

MENDONÇA, Luís. Luís Mendonça (depoimento, 1996). Rio de Janeiro: CPDOC/ FUNDAÇÃO ESCOLA NACIONAL DE SEGUROS, 1998. 34 p. dat. Texto disponível no site http://www.fgv.br/cpdoc/historiaoral/arq/Entrevista169.pdf. Acesso em 24.08.2010.

PARK, James Allan. A System of the Law of marine insurances. Londres: T. Whieldon, 1787. Disponível em: <http://books.google.com.br>. Acesso em: 2 nov 2011.

\section{Bibliografia}

ABREU, Marcelo de Paiva; FERNANDES, Felipe Tâmega. The insurance industry in Brazil: a long-term view. Working Paper 10-109, Harvard Business School, 2010. Disponível em: <http://www.hbs.edu/research/pdf/10-109.pdf>. Acesso em: 06 abr 2011.

ALBERTI, Verena (Coord.). Entre a solidariedade e o risco: história do seguro privado no Brasil. Rio de Janeiro: Fundação Getúlio Vargas, 1998.

ALMEIDA, Cândido Mendes. Ao Leitor. In: LISBOA, José da Silva, visconde de Cairu. Princípios de direito mercantil e leis de marinha. $6^{\mathrm{a}}$ ed. Tomos I e II. Rio de Janeiro: Typographia Acadêmica, 1874, p. v-xii.

ALVES, Jorge Fernandes. A Difusão da técnica atuarial e as primeiras companhias de seguros no Porto (século XIX). Revista da Faculdade de Letras HISTÓRIA, Porto, III 
série, vol. 6, 2005, pp. 193-209. Disponível em: <http://ler.letras.up.pt/uploads/ficheiros/3384.pdf>. Acesso em: 23 abr 2010.

ALVIM, Pedro. O Contrato de Seguro. $3^{\mathrm{a}}$ ed. Rio de Janeiro: Forense, 2001.

ARRIGHI, Giovanni; trad.: Vera Ribeiro. O longo século XX: dinheiro, poder e as origens de nosso tempo. Rio de Janeiro: Contraponto; São Paulo: Ed. Unesp, 1996.

BANDECCHI, Brasil. Legislação básica sobre a escravidão africana no Brasil. Revista de História, São Paulo, vol. 44, p. 207-213, 1972.

BERNSTEIN, Peter L (trad.: Ivo Korytowski). Desafio aos Deuses: a fascinante história do risco. $3^{\mathrm{a}}$ edição. Rio de Janeiro: Campus, 1997.

BETHELL, Leslie (trad.: Vera Nunes Neves Pedroso). A Abolição do tráfico de escravos no Brasil: a Grã-Bretanha, o Brasil e a questão do tráfico de escravos, 1807-1869. Rio de Janeiro-São Paulo: Expressão e Cultura-EDUSP, 1976.

BLAKE, Augusto Victorino Alves Sacramento. Diccionário Bibliographico Brasileiro. 7 vols.. [Rio de Janeiro]: Conselho Federal de Cultura, 1970. Disponível em: <www.brasiliana.usp.br>. Acesso em: $01 \mathrm{dez} 2011$.

BOHRER, Saulo Santiago. O "seguro" morreu de velho: a Associação dos Seguros Mútuos Brasileiros na manutenção dos interesses dos negociantes no Rio de Janeiro. Texto de discussão $n^{\circ}$ 6, apresentado ao Polis - Laboratório de História Econômico-Social. Niteroi/ RJ: UFF, 2004. Disponível em: < http://www.historia.uff.br/polis/files/texto_9.pdf>. Acesso em: 15 jul 2011.

Política e economia: Provedoria dos Seguros e políticas para a atividade de seguros no Rio de Janeiro (1810/1831). Anais do XXIV Simpósio Nacional de História ANPUH, 2007. Disponível em:

$<$ http://snh2007.anpuh.org/resources/content/anais/Saulo\%20Santiago\%20Bohrer.pdf $>$. Acesso em: 15 jul 2011. 
- "Interesses Seguros": as companhias de seguro e a Provedoria dos Seguros do Rio de Janeiro (1810-1831). Dissertação (Mestrado em História) - Universidade Federal Fluminense/ UFF, Niteroi/ RJ, 2008. Disponível em: < http://www.historia.uff.br/stricto/teses/Dissert-2008_BOHER_Saulo_Santiago-S.pdf>. Acesso em: 15 jul 2011.

CASTRO, Ana Célia. As Empresas estrangeiras no Brasil: 1860-1913. Dissertação (Mestrado em Economia) - Instituto de Filosofia e Ciências Humanas, Universidade de Campinas/ UNICAMP, Campinas/ SP, 1976. Disponível em: <http://cutter.unicamp.br/document/?code=000017639>. Acesso em: 07 jul 2011.

CASTRO, Antonio Barros de et al. Trabalho escravo, economia e sociedade. Rio de Janeiro: Paz e Terra, 1984.

CHEN, Cheryl Rhan-Hsin; SIMON, Gary. Acturial issues in insurance on slaves in the United States South. The Journal of African American History, vol. 89, n. 4, 2004, p. 348357.

Dicionário histórico-biográfico das Ciências da Saúde no Brasil (1832-1930). Disponível em: < http://www.dichistoriasaude.coc.fiocruz.br>. Acesso em: $01 \mathrm{dez} 2011$.

DUTRA, Pedro. Literatura Jurídica no Império. $2^{\circ}$ ed. Rio de Janeiro: Padma, 2004.

FERREIRA, Waldemar Martins. As diretrizes do direito mercantil brasileiro. Lisboa: Tip. da Empresa do Anuário Comercial, 1933.

FLORENTINO, Manolo. Em Costas negras: uma história do tráfico de escravos entre a África e o Rio de Janeiro (séculos XVIII e XIX). São Paulo: Companhia das Letras, 2002.

GALHARDO, José Emydio Rodrigues. História da homeopatia no Brasil. In: Livro do $1^{o}$ Congresso Brasileiro de Homeopatia. Rio de Janeiro: Instituto Hahnermanniano do Brasil, 1928. Disponível em: <www.brasiliana.usp.br>. Acesso em: 1 dez 2011. 
GARCIA NETO, Paulo Macedo, O Judiciário no crepúsculo do Império (1871-1889). In: LOPES, José Reinaldo de Lima (Org.). O Supremo Tribunal de Justiça do Império (18281889). São Paulo: Saraiva, 2010.

GRINBERG, Keila. Escravidão, alforria e direito no Brasil oitocentista: reflexões sobre a lei de 1831 e o "princípio da liberdade" na fronteira sul do Império brasileiro. In: CARVALHO, José Murilo de (Org.). Nação e cidadania no Império: novos horizontes. Rio de Janeiro: Civilização Brasileira, 2007, p. 267-285.

Senhores sem escravos: a propósito das ações de escravidão no Brasil Imperial. Almanack Braziliense, São Paulo, n. 6, pp. 04-13, nov./ 2006. Disponível em: <http://www.brasiliana.usp.br/almanack/index.php/almanack>. Acesso em: 02 nov 2010.

INSTITUTO DE RESSEGUROS DO BRASIL. Noções Fundamentais de Seguros. Publicação n. 15. Rio de Janeiro: Imprensa Nacional, 1944.

ITAGYBA, J. Nogueira. Tratado sobre seguros de vida. Rio de Janeiro: Companhia Typographica do Brasil, 1900.

LE GOFF, Jacques (trad.: Rogerio Silveira Muoio; ver. téc.: Hilário Franco Júnior). A bolsa e a vida: economia e religião na Idade Média. São Paulo: Brasiliense, 2004.

LIBBY, Douglas Cole. Trabalho escravo e Capital estrangeiro no Brasil: o caso de Morro Velho. Belo Horizonte: Itatiaia, 1984.

LISBOA, Bento da Silva. Biografia de José da Silva Lisboa, visconde de Cayrú. Revista do Instituto Histórico e Geográfico do Brasil-RIHGB, n. 3, t. 1, $3^{\circ}$ trimestre de 1839, p. 185 191. $3^{\text {a }}$ ed. Rio de Janeiro: Imprensa Nacional, 1908. Disponível em: <http://www.ihgb.org.br/rihgb.php?s=p>. Acesso em: 23 set 2011. 
LOBO, Eulália Maria Lahmeyer. Economia do Rio de Janeiro nos séculos XVIII e XIX. In: NEUHAUS, Paulo (Coord.). Economia brasileira: uma visão histórica. Rio de Janeiro: Campus, 1980.

LOPES, José Reinaldo de Lima. A Formação do direito comercial brasileiro: a criação dos tribunais de comércio do império. Cadernos DireitoGV, São Paulo, v.4, n.6: novembro de 2007.

O Direito na história: lições introdutórias. $3^{\mathrm{a}}$ ed. São Paulo: Atlas, 2008.

O Oráculo de Delfos: Conselho de Estado e direito no Brasil oitocentista. São Paulo: Saraiva, 2010a.

O Supremo Tribunal de Justiça no apogeu do Império (1840-1871). In: LOPES, José Reinaldo de Lima (Org.). O Supremo Tribunal de Justiça do Império (1828-1889). São Paulo: Saraiva, 2010b.

MAGALHÃES, Raphael de Almeida. O mercado de seguros no Brasil. Rio de Janeiro: Funenseg, 1997.

MAMIGONIAN, Beatriz Gallotti. O Direito de ser africano livre: os escravos e as interpretações da lei de 1831. In: LARA, Silvia Hunold; MENDONÇA, Joseli Maria Nunes (Orgs.). Direitos e justiças no Brasil: ensaios de história social. Campinas, SP: Ed. da Unicamp, 2006.

A Proibição do tráfico atlântico e a manutenção da escravidão. In: GRINBERG, Keila; SALLES, Ricardo (Orgs.). O Brasil Imperial, volume I: 1808-1831. Rio de Janeiro: Civilização Brasileira, 2009.

MARQUESE, Rafael de Bivar. A Administração do trabalho escravo nos manuais de fazendeiro do Brasil Império, 1830-1847. Revista de História, São Paulo, n. 137, p. 95$111,1997$. 
MARQUESE, Rafael de Bivar; PARRON, Tâmis Peixoto. Azeredo Coutinho, Visconde de Araruama e a Memória sobre o Comércio de Escravos de 1838. Revista de História, São Paulo, n. 152, p. 99-126, $1^{\circ}-2005$.

A dinâmica da escravidão no Brasil. Novos Estudos, São Paulo, n. 74, p. 107-132, mar. 2006.

MARQUESE, Rafael; TOMICH, Dale. O Vale do Paraíba escravista e a formação do mercado mundial do café no século XIX. In: GRINBERG, Keila; SALLES, Ricardo (Orgs.). O Brasil Imperial, volume II: 1831-1870. Rio de Janeiro: Civilização Brasileira, 2009.

MARQUESE, Rafael de Bivar. Administração \& escravidão: idéias sobre a gestão da agricultura escravista brasileira. 2a ed. São Paulo: Hucitec, 2010.

MEGLIORINI, Leandro. Seguros de grossa aventura: a companhia de seguros Indemnidade à época joanina. Anais do XII Encontro Regional de História ANPUH-RJ 'Usos do Passado', 2006. Disponível em:

$<$ http://www.rj.anpuh.org/resources/rj/Anais/2006/conferencias/Leandro\%20Megliorini.pd f>. Acesso em: 16 ago 2011.

A Companhia de Seguros Indemnidade: história de empresas no Brasil joanino (1808-1822). Dissertação (Mestrado em História) - Instituto de Ciências Humanas e Filosofia, Universidade Federal Fluminense, UFF, 2008. Disponível em: $<$ http://www.historia.uff.br/stricto/teses/Dissert-2008_MEGLIORINI_Leandro-S.pdf $>$. Acesso em: 16 ago 2011.

MELLO, Pedro Carvalho de. Aspectos econômicos da organização do trabalho da economia cafeeira do Rio de Janeiro, 1850-88. Revista Brasileira de Economia, Rio de Janeiro, 32 (1), p. 19-67, jan./ mar. 1978. 
MELLO, Pedro Carvalho de; SLENES, Robert W. Análise econômica da escravidão no Brasil. In: NEUHAUS, Paulo (Coord.). Economia brasileira: uma visão histórica. Rio de Janeiro: Campus, 1980.

NEQUETE, Lenine. O Poder Judiciário no Brasil: crônicas dos tempos coloniais. Brasília: Supremo Tribunal Federal, 2000. Vol. 1.

O Poder Judiciário no Brasil a partir da Independência (I - Império). Brasília: Supremo Tribunal Federal, 2000.

PARRON, Tâmis Peixoto. Introdução. In PARRON, Tâmis Peixoto (Org.). José de Alencar: Cartas a favor da escravidão. São Paulo: Hedra, 2008.

. A política da escravidão no Império do Brasil, 1826-1865. Dissertação (Mestrado em História) - Faculdade de Filosofia, Letras e Ciências Humanas, Universidade de São Paulo, USP, 2009. Disponível em: <http://www.teses.usp.br/teses/disponiveis/8/8138/tde04022010-112116/pt-br.php>. Acesso em: 11 nov 2010.

PENALVES ROCHA, Antonio. A escravidão na economia política. Revista de História, Nova Série, São Paulo, n. 120, pp. 97-108, jan./ jul., 1989.

. Introdução. In: PENALVES ROCHA, Antonio (org.). José Da Silva Lisboa, Visconde de Cairu. São Paulo: Ed. 34, 2001.

PINHEIRO, Joely Aparecida Ungaretti. Empresas alemãs no Estado de São Paulo: 18731940. Dissertação (Mestrado em História Econômica) - Instituto de Economia, Universidade de Campinas, Campinas/SP, 2001. Disponível em: < http://cutter.unicamp.br/document/?code=vtls000243560>. Acesso em: 07 jul 2011.

POLANYI, Kart; trad.: Fanny Wrobel. A grande transformação: as origens de nossa época. $2^{\mathrm{a}}$ edição. Rio de Janeiro: Elsevier, 2000. 
RODRIGUES, Jaime. O Infame Comércio: propostas e experiências no final do tráfico de africanos para o Brasil (1800-1850). Campinas, SP: Unicamp/ Cecult, 2000.

. O Fim do tráfico transatlântico de escravos para o Brasil: paradigmas em questão. In: GRINBERG, Keila; SALLES, Ricardo (Orgs.). O Brasil Imperial, volume II: 18311870. Rio de Janeiro: Civilização Brasileira, 2009.

SAES, Alexandre Macchione; GAMBI, Thiago Fontelas Rosado. A Formação das companhias de seguros na economia brasileira (1808-1864). História Econômica \& história de empresas, Campinas/ SP, XII, 2, 2009.

SAVITT, Todd L. Slave life insurance in Virginia and North Carolina. The Journal of Southern History, v. 43, n. 4, nov. 1977, p. 583-600 (Errata publicada em The Journal of Southern History, v. 44, n. 1, fev. 1978, p. 163).

SISSON, S. A. (Ed). Galeria dos Brasileiros Ilustres. Brasília: Senado Federal, 1999. 2 vols. Disponível em: <http://www2.senado.gov.br/bdsf/item/id/1027>. Acesso em: 23 set 2011.

SLEMIAN, Andréa et al. Cronologia de história do Brasil colonial (1500-1831). São Paulo: FFLCH-USP, 1994.

SLEMIAN, Andréa; PIMENTA, João Paulo G. $O$ “nascimento político” do Brasil: as origens do Estado e da nação (1808-1825). Rio de Janeiro: DP\&A, 2003.

. A Corte e o mundo: uma história do ano em que a família real portuguesa chegou ao Brasil. São Paulo: Alameda, 2008.

TAVARES, Luís Henrique Dias. Comércio proibido de escravos. São Paulo: Ática, 1988a.

O capitalismo no comércio proibido de escravos. Revista do Instituto de Estudos Brasileiros, São Paulo, n. 28, pp. 37-52, 1988 b. 


\section{ANEXO 1:}

\begin{tabular}{|c|c|c|}
\hline \multicolumn{3}{|r|}{$\begin{array}{l}\text { Quadro da legislação sobre seguros } \\
\text { (séculos XVII, XVIII e XIX) }\end{array}$} \\
\hline Data & Norma & Ementa \\
\hline 11.03 .1695 & Decreto & $\begin{array}{l}\text { Decreto, em que se mandou tomar Assento sobre a dúvida se nas causas de seguros, que fazem homens de } \\
\text { negócio, havia de ter lugar a cláusula depositária. }\end{array}$ \\
\hline 14.04 .1695 & Assento & Cláusula depositária tem lugar nas causas dos Seguros feitos pelos homens de negócio. \\
\hline 17.01.1757 & Alvará & Proíbe dar-se dinheiro à juro senão a cinco por cento anualmente. \\
\hline 28.08 .1758 & & (Obs.: Regulamento da Casa de Seguros de Lisboa). \\
\hline 19.05.1759 & Alvará & $\begin{array}{l}\text { (Obs.: Estatutos da Aula do Comércio: Dentre as matérias a ser ensinadas: "14. Os Seguros com as suas } \\
\text { distinções de loja a loja, ou de âncora a âncora; de modo ordinário, ou de pacto expresso, e a notícia das } \\
\text { apólices, assim na Praça de Lisboa, como em todas as mais da Europa; como também a formalidade dos } \\
\text { fretamentos, a prática das comissões, e as obrigações, que delas resultam, devem ser todas tratadas, ao menos, } \\
\text { para o suficiente conhecimento de cada uma das partes, com o qual se adquiram as disposições para chegar à } \\
\text { perfeição em seu tempo." }\end{array}$ \\
\hline 11.08 .1791 & Alvará & (Obs.: Confirmação do regulamento da Casa de Seguros de Lisboa). \\
\hline 07.02 .1793 & Assento & $\begin{array}{l}\text { Causas entre Segurados e Seguradores pertencem presentemente à Casa dos Seguros, à exceção das } \\
\text { pendentes no Juízo de Índia e Mina. }\end{array}$ \\
\hline 23.08 .1808 & Alvará & Cria o Tribunal da Real Junta do Comércio, Agricultura, Fábricas e Navegação. \\
\hline 29.07.1809 & Alvará & Sobre a recepção dos negociantes falidos, matriculados na Junta do Comércio. \\
\hline 05.05 .1810 & Alvará & Permite que para o Comércio marítimo se possa dar dinheiro por qualquer prêmio que se ajuste. \\
\hline 05.03 .1829 & Decreto & $\begin{array}{l}\text { Dá Regulamento à Administração Geral dos Correios (Obs.: Cf. Capítulo IV: Dos Seguros - arts. } 84 \text { a 86); } \\
\text { Titulo V: Da Contabilidade, e escrituração - especialmente arts. 139,142, } 145 \text { a } 148,\end{array}$ \\
\hline 03.10 .1812 & Alvará & $\begin{array}{l}\text { Determina que as Mesas de Inspeção sirvam de Juiz Executor das sentenças da Real Junta do Comércio nas } \\
\text { causas de Seguro, etc. e de Juiz e Conservador das Fábricas. }\end{array}$ \\
\hline
\end{tabular}




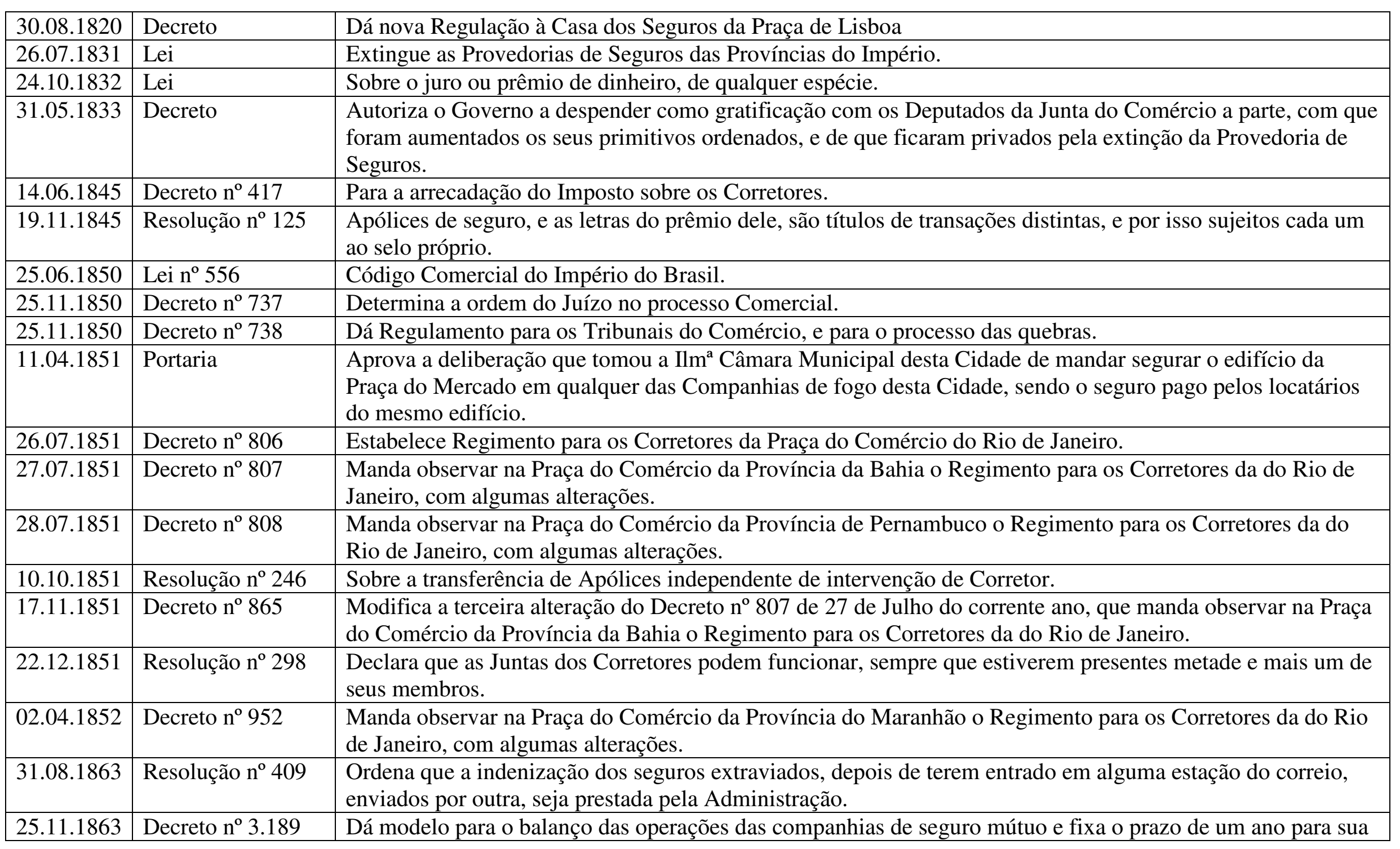




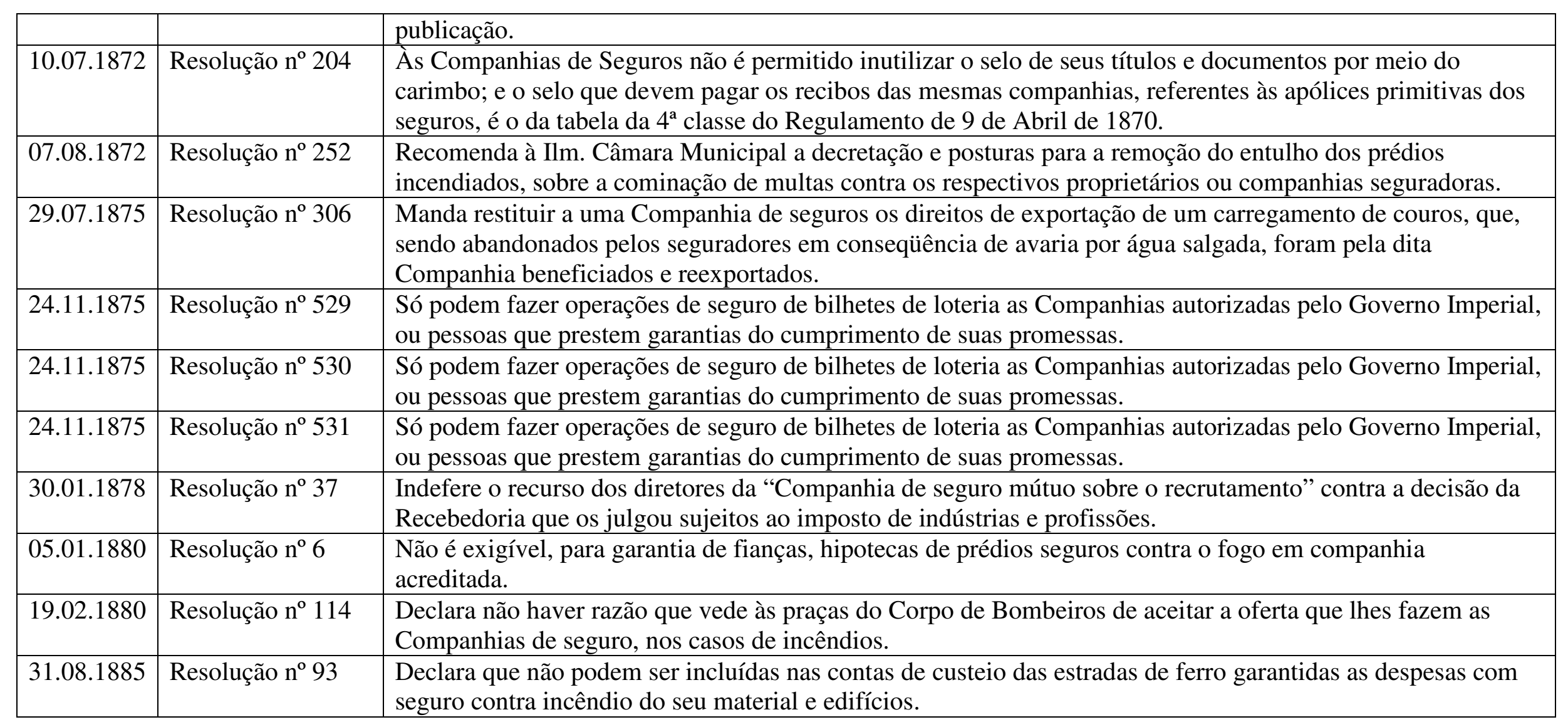




\section{ANEXO 2:}

\section{Companhias de Seguros em funcionamento na Província do Rio de Janeiro (1808-1889)}

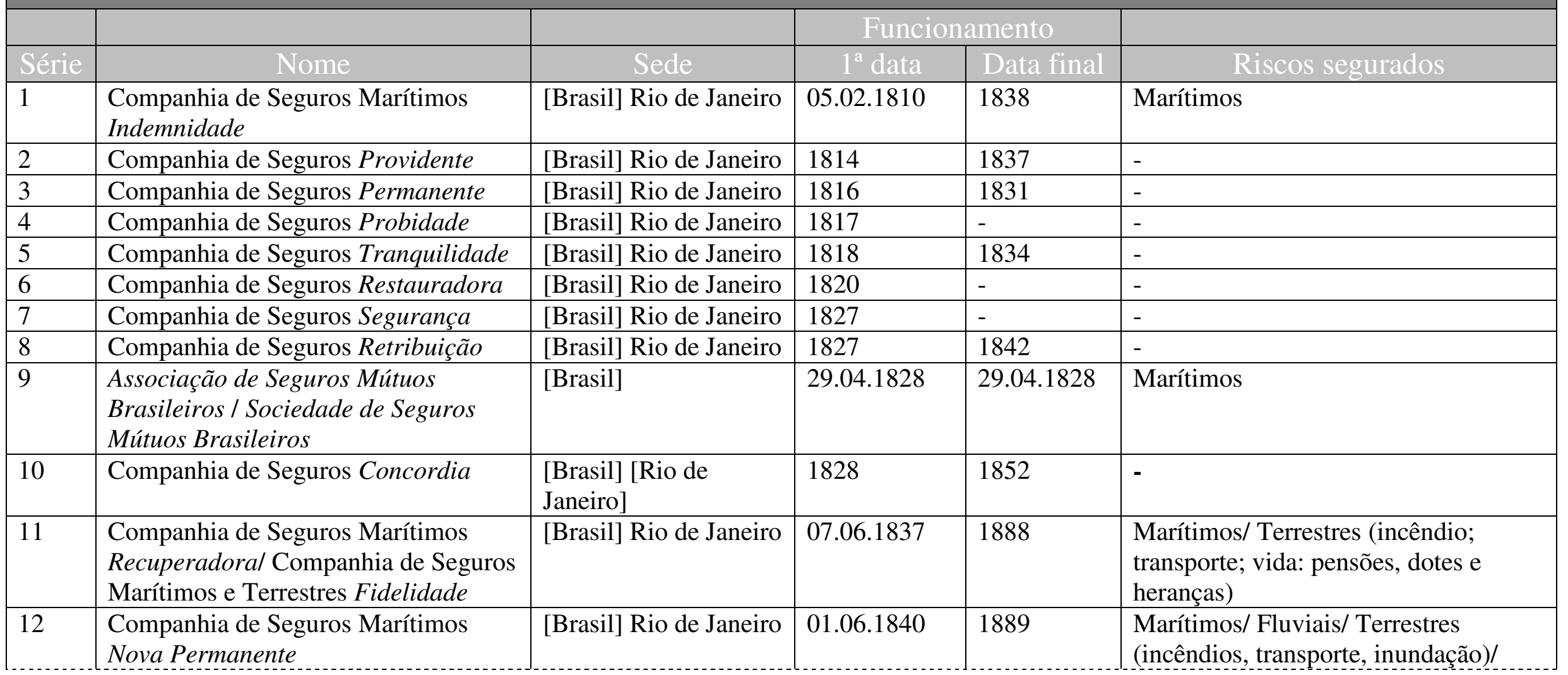




\begin{tabular}{|c|c|c|c|c|c|}
\hline & & & & & Câmbio marítimo \\
\hline 13 & (Agência) Lloyd Fluminense & [Estrangeira] & 1843 & 1846 & Marítimos \\
\hline 14 & (Agência) Lloyd Austríaco de Trieste & [Estrangeira] Áustria & 1843 & 1862 & - \\
\hline 15 & $\begin{array}{l}\text { Agência dos Seguradores de } \\
\text { Hamburgo }\end{array}$ & $\begin{array}{l}\text { [Estrangeira] } \\
\text { Hamburgo, Alemanha }\end{array}$ & 1843 & 1870 & - \\
\hline 16 & $\begin{array}{l}\text { Phenix Fluminense (incorporou-se na } \\
\text { Argos Fluminense, vide } \mathrm{n}^{\circ} 20 \text { ) }\end{array}$ & [Brasil] Rio de Janeiro & 1843 & 1855 & Terrestres (incêndios) \\
\hline 17 & $\begin{array}{l}\text { Companhia de Seguros Regeneração } \\
\text { (liquidou-se: vide Nova Regeneração, } \\
\mathrm{n}^{\circ} \text { 53) }\end{array}$ & [Brasil] & 1844 & 1860 & - \\
\hline 18 & $\begin{array}{l}\text { Reunião de Seguradores particulares } \\
\text { de riscos marítimos (vide Seguridade, } \\
\mathrm{n}^{\circ} 40 \text { ) }\end{array}$ & [Brasil] Rio de Janeiro & 1845 & 1855 & Marítimos \\
\hline 19 & $\begin{array}{l}\text { Companhia de Seguros sobre a Vida } \\
\text { dos Escravos Prosperidade }\end{array}$ & [Brasil] Rio de Janeiro & 1845 & 1845 & Terrestres (vida de escravos) \\
\hline 20 & $\begin{array}{l}\text { Companhia de Seguros contra fogo } \\
\text { Argos Fluminense (incorporou a } \\
\text { Phenix Fluminense, vide } \mathrm{n}^{\circ} 16 \text { ) }\end{array}$ & [Brasil] Rio de Janeiro & 1846 & 1888 & Terrestres (incêndios) \\
\hline 21 & $\begin{array}{l}\text { (Agência) Companhias de Seguros } \\
\text { marítimos de Paris }\end{array}$ & $\begin{array}{l}\text { [Estrangeira] Paris, } \\
\text { França }\end{array}$ & 1846 & 1880 & Marítimos \\
\hline 22 & $\begin{array}{l}\text { (Agência) Companhias de Seguros } \\
\text { marítimos de Hàvre }\end{array}$ & $\begin{array}{l}\text { [Estrangeira] Havre, } \\
\text { França }\end{array}$ & 1847 & 1880 & Marítimos \\
\hline 23 & $\begin{array}{l}\text { (Agência) Companhias de Seguros } \\
\text { marítimos de Antuérpia }\end{array}$ & $\begin{array}{l}\text { [Estrangeira] } \\
\text { Antuérpia, Bélgica }\end{array}$ & 1848 & 1880 & Marítimos \\
\hline 24 & $\begin{array}{l}\text { (Agência) Companhia Ibérica de } \\
\text { Seguros Marítimos }\end{array}$ & $\begin{array}{l}\text { [Estrangeira] } \\
\text { Barcelona, Espanha }\end{array}$ & 1849 & 1861 & Marítimos \\
\hline 25 & $\begin{array}{l}\text { (Agência) Companhias de Seguros } \\
\text { marítimos de Wesel }\end{array}$ & $\begin{array}{l}\text { [Estrangeira] Wesel, } \\
\text { Alemanha }\end{array}$ & 1851 & 1866 & Marítimos \\
\hline 26 & $\begin{array}{l}\text { (Agência) Companhias de Seguros } \\
\text { marítimos de Cologne }\end{array}$ & [Estrangeira] Cologne & 1851 & 1866 & Marítimos \\
\hline
\end{tabular}




\begin{tabular}{|c|c|c|c|c|c|}
\hline $27^{-1}$ & $\begin{array}{l}\text { (Agência) Companhias Unidas de } \\
\text { Seguros Marítimos de Trieste }\end{array}$ & $\begin{array}{l}\text { [Estrangeira] Trieste, } \\
\text { Itália }\end{array}$ & 1852 & 1862 & Marítimos \\
\hline 28 & $\begin{array}{l}\text { (Agência) Imperial Companhia de } \\
\text { Seguros contra o Fogo (Imperial Fire } \\
\text { Insurance Company) }\end{array}$ & $\begin{array}{l}\text { [Estrangeira] Londres, } \\
\text { Inglaterra }\end{array}$ & 1853 & 1888 & Terrestres (incêndios) \\
\hline 29 & $\begin{array}{l}\text { (Imperial) Companhia de Seguro } \\
\text { Mútuo Contra Fogo }\end{array}$ & [Brasil] Rio de Janeiro & 01.04 .1854 & 1889 & Terrestres (incêndios) \\
\hline 30 & Companhia de Seguros Previdência & [Brasil] Rio de Janeiro & 05.08 .1854 & 1859 & Terrestres (vida de escravos) \\
\hline 31 & $\begin{array}{l}\text { (Agência) Companhias de Seguros } \\
\text { Marítimos de Dusseldorf }\end{array}$ & $\begin{array}{l}\text { [Estrangeira] } \\
\text { Dusseldorf, Alemanha }\end{array}$ & 1854 & 1866 & Marítimos \\
\hline 32 & $\begin{array}{l}\text { (Agência) Companhia de Seguros } \\
\text { Marítimos de Marseille }\end{array}$ & $\begin{array}{l}\text { [Estrangeira] } \\
\text { Marseille, França }\end{array}$ & 1854 & 1888 & Marítimos \\
\hline 33 & $\begin{array}{l}\text { (Agência) Corporação de Seguros } \\
\text { Assurance }\end{array}$ & $\begin{array}{l}\text { [Estrangeira] Londres, } \\
\text { Inglaterra }\end{array}$ & 1855 & 1859 & Terrestres (incêndios) \\
\hline 34 & $\begin{array}{l}\text { (Agência) Companhia Barceloneza de } \\
\text { Seguros Marítimos }\end{array}$ & $\begin{array}{l}\text { [Estrangeira], } \\
\text { Barcelona, Espanha }\end{array}$ & 1855 & 1855 & Marítimos \\
\hline 35 & $\begin{array}{l}\text { (Agência) Companhia de Seguros } \\
\text { "Equidade" }\end{array}$ & $\begin{array}{l}\text { [Estrangeira] Porto, } \\
\text { Portugal }\end{array}$ & 1855 & 23.10 .1861 & Marítimos/ Terrestres (incêndios) \\
\hline 36 & $\begin{array}{l}\text { (Agência) Companhias de Seguros de } \\
\text { Boston, Philadelphia e Baltimore }\end{array}$ & $\begin{array}{l}\text { [Estrangeira] Estados } \\
\text { Unidos }\end{array}$ & 1855 & 1855 & - \\
\hline 37 & $\begin{array}{l}\text { (Agência) Companhia de Seguros } \\
\text { Fidelidade }\end{array}$ & $\begin{array}{l}\text { [Estrangeira] Lisboa, } \\
\text { Portugal }\end{array}$ & 1855 & 23.09 .1882 & Marítimos/ Terrestres \\
\hline 38 & $\begin{array}{l}\text { Agents of Underwriters of the City of } \\
\text { New York/ (Agência) Companhias de } \\
\text { Seguros Marítimos de New York }\end{array}$ & $\begin{array}{l}\text { [Estrangeira] Nova } \\
\text { York, Estados Unidos }\end{array}$ & 1855 & 1862 & Marítimos \\
\hline 39 & Companhia de Seguros Tranquilidade & [Brasil] Rio de Janeiro & 07.11 .1855 & 06.02 .1858 & $\begin{array}{l}\text { Terrestres (vida de escravos; vida de } \\
\text { pessoas livres) }\end{array}$ \\
\hline 40 & $\begin{array}{l}\text { Companhia de Seguros Marítimos } \\
\text { Seguridade (antiga Reunião de } \\
\text { seguradores particulares, vide } \mathrm{n}^{\mathrm{o}} \text { 18) }\end{array}$ & [Brasil] Rio de Janeiro & 23.04 .1856 & 1864 & Marítimos \\
\hline
\end{tabular}




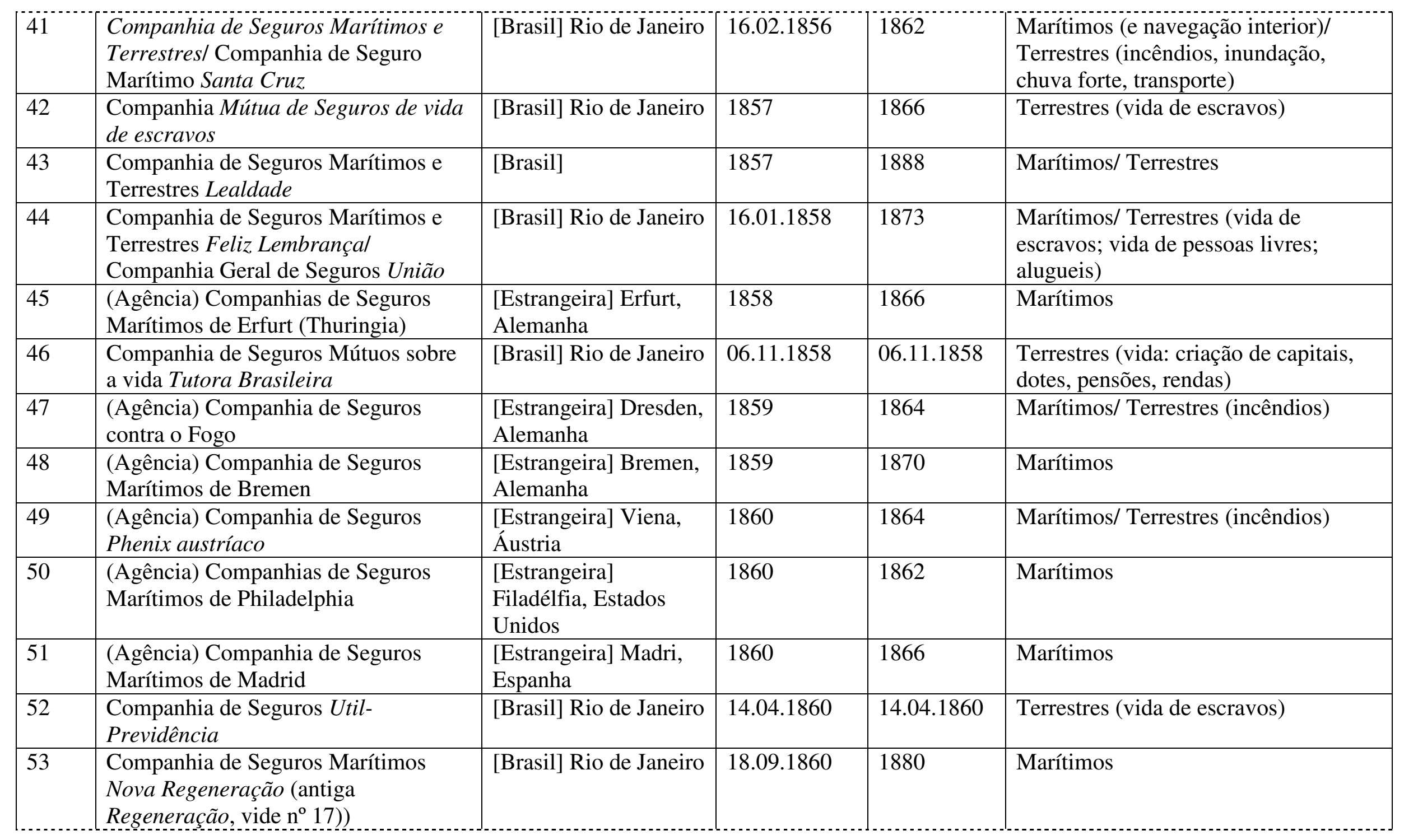




\begin{tabular}{|c|c|c|c|c|c|}
\hline 54 & Junta de Seguradores Marítimos & [Brasil] & 1861 & 1861 & Marítimos \\
\hline 55 & $\begin{array}{l}\text { (Agência) Companhias de Seguros } \\
\text { Marítimos de Gênova }\end{array}$ & $\begin{array}{l}\text { [Estrangeira] Gênova, } \\
\text { Itália }\end{array}$ & 1861 & 1888 & Marítimos \\
\hline 56 & $\begin{array}{l}\text { (Agência) Companhias de Seguros } \\
\text { Marítimos de Bordeaux }\end{array}$ & $\begin{array}{l}\text { [Estrangeira] } \\
\text { Bordeaux, França }\end{array}$ & 1861 & 1880 & Marítimos \\
\hline 57 & $\begin{array}{l}\text { Companhia de Seguro Mútuo contra o } \\
\text { fogo Alliança }\end{array}$ & [Brasil] Rio de Janeiro & 09.04 .1863 & 1870 & Terrestres (incêndios) \\
\hline 58 & (Agência) Sociedade la Ausiliadora & $\begin{array}{l}\text { [Estrangeira] } \\
\text { Barcelona, Espanha }\end{array}$ & 1863 & 1870 & - \\
\hline 60 & $\begin{array}{l}\text { (Agência) Real Companhia Inglesa de } \\
\text { Seguros (The Royal Insurance } \\
\text { Company) }\end{array}$ & $\begin{array}{l}\text { [Estrangeira] } \\
\text { Liverpool, Inglaterra }\end{array}$ & 23.02 .1864 & 1888 & Terrestres (incêndios) \\
\hline 61 & $\begin{array}{l}\text { Sociedade de Seguros Mútuos sobre a } \\
\text { vida Protetora das Famílias (gerida } \\
\text { pelo Banco Rural e Hipotecário) }\end{array}$ & [Brasil] Rio de Janeiro & 13.06 .1864 & 1888 & $\begin{array}{l}\text { Terrestres (vida: criação de capital, } \\
\text { renda) }\end{array}$ \\
\hline 63 & $\begin{array}{l}\text { (Agência) Sociedade Portuguesa de } \\
\text { Seguros Mútuos sobre a Vida } A \\
\text { Previdente }\end{array}$ & [Estrangeira] Portugal & 1866 & 1866 & - \\
\hline 64 & $\begin{array}{l}\text { (Agência) Liverpool and London } \\
\text { Insurance Company/ Liverpool and } \\
\text { London and Globe Insurance } \\
\text { Company }\end{array}$ & $\begin{array}{l}\text { [Estrangeira] } \\
\text { Inglaterra }\end{array}$ & 22.06 .1866 & 1870 & Terrestres (incêndios) \\
\hline 65 & $\begin{array}{l}\text { (Agência) Northern Assurance } \\
\text { Company }\end{array}$ & $\begin{array}{l}\text { [Estrangeira] } \\
\text { Inglaterra }\end{array}$ & 13.03 .1867 & 13.06 .1888 & - \\
\hline 66 & (Agência) Queen Insurance & [Estrangeira] & 25.01 .1868 & 1870 & Terrestres (incêndios) \\
\hline
\end{tabular}




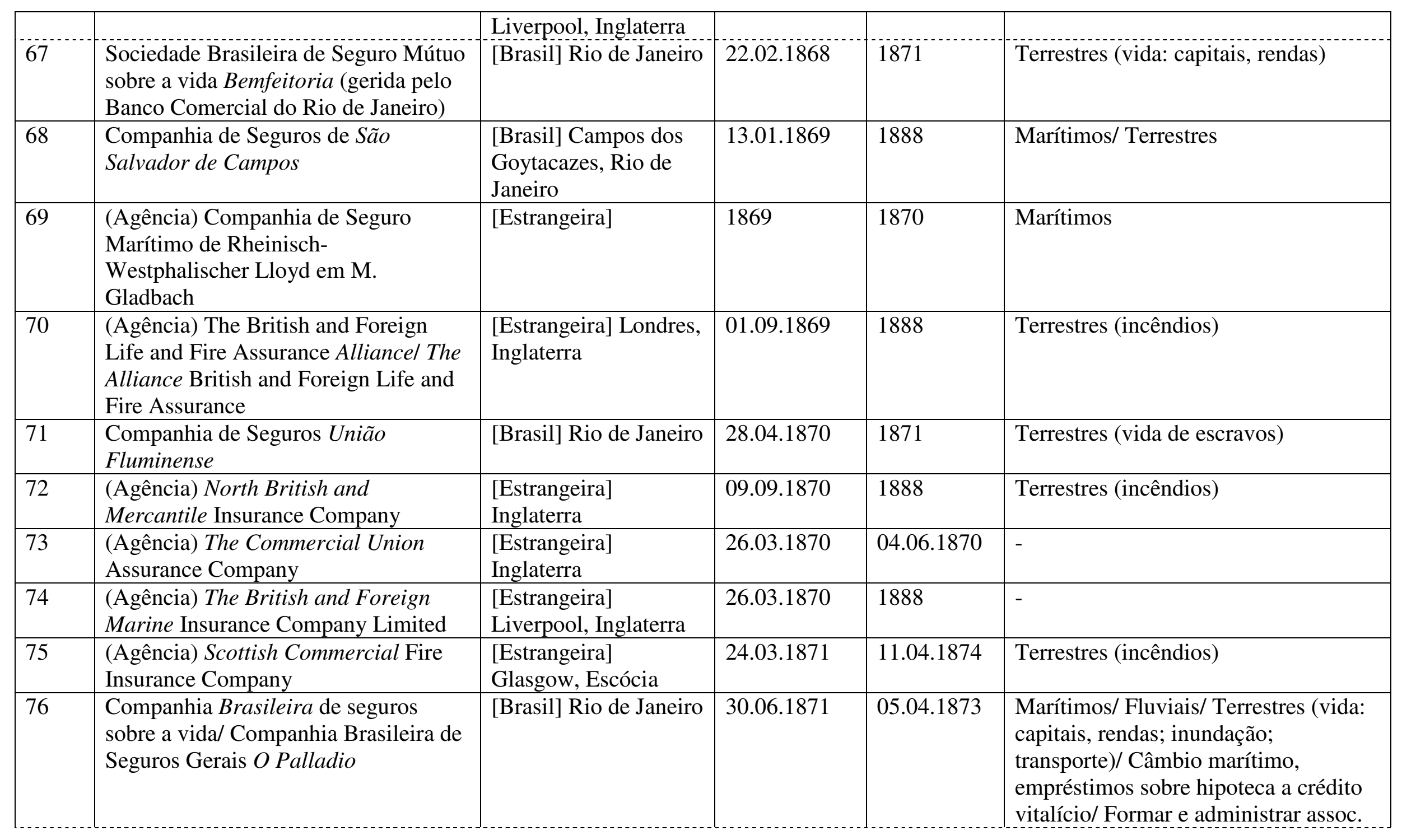




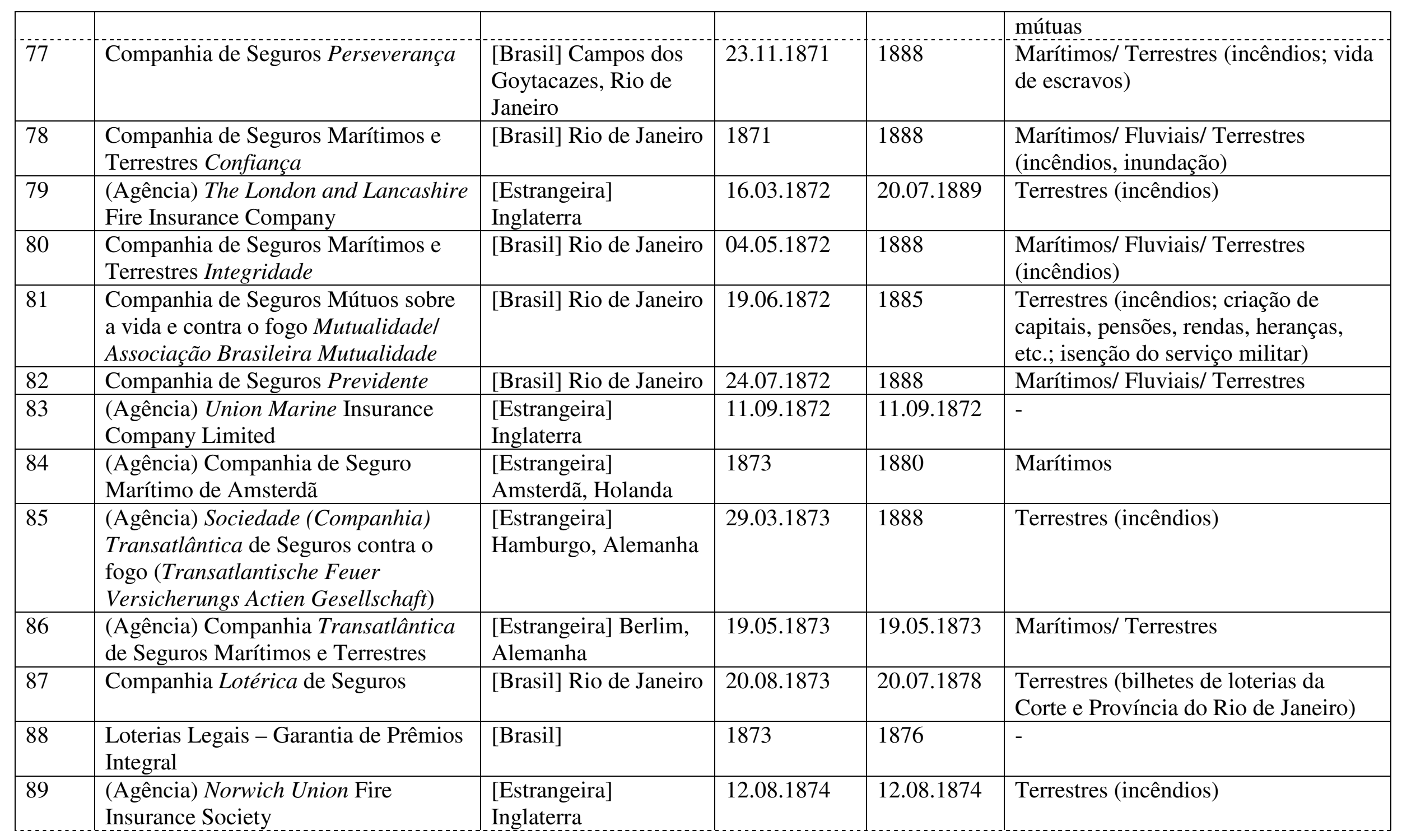




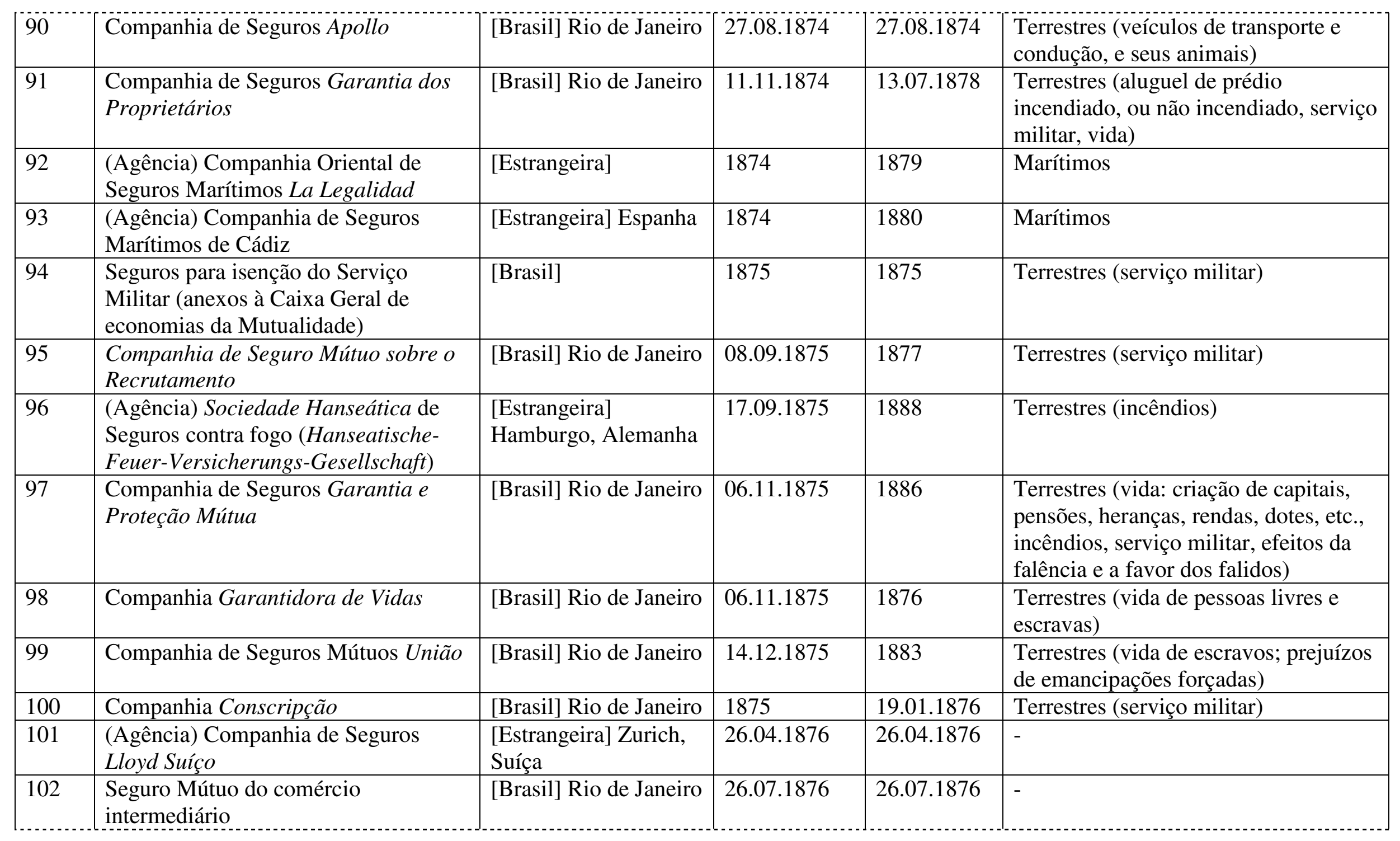




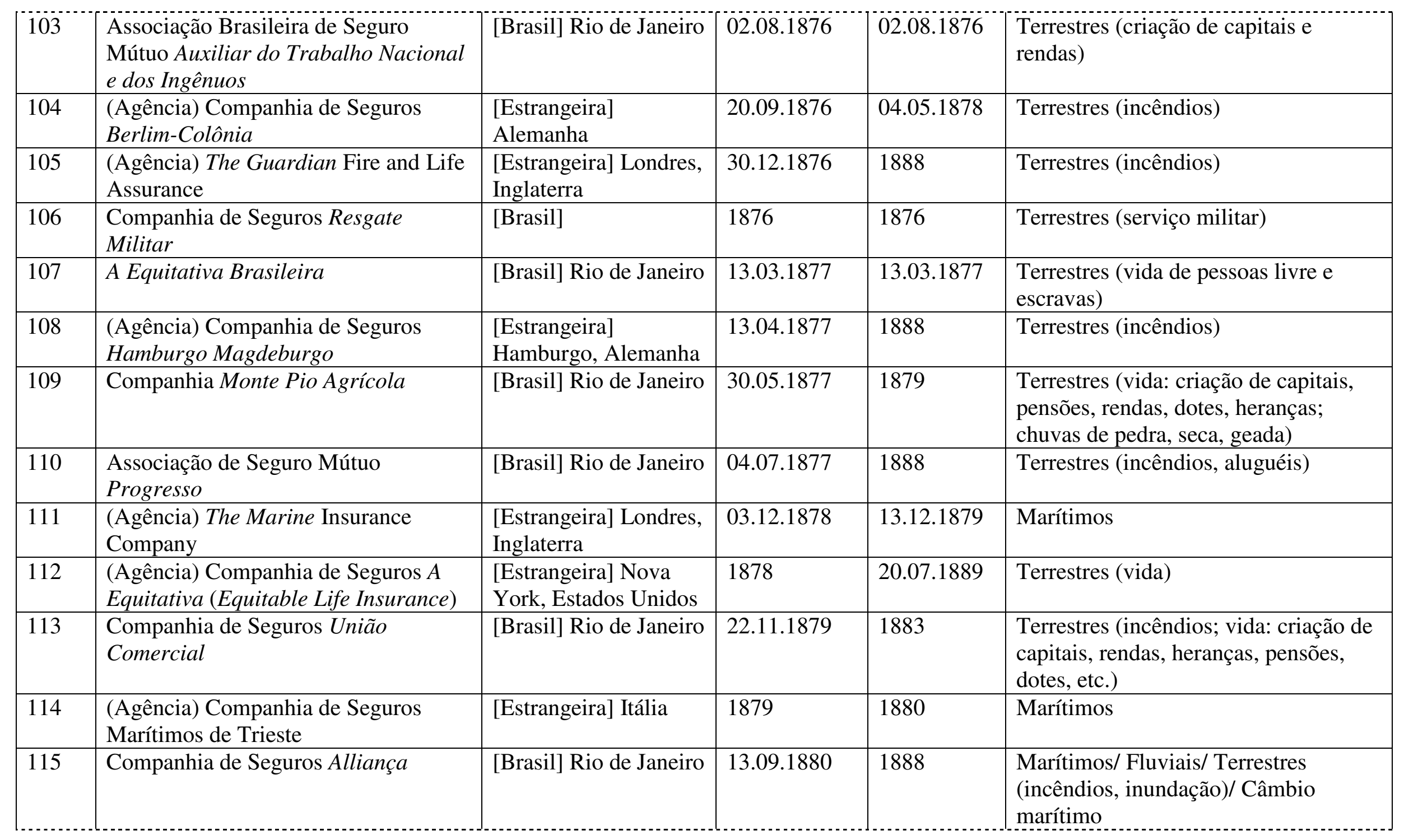




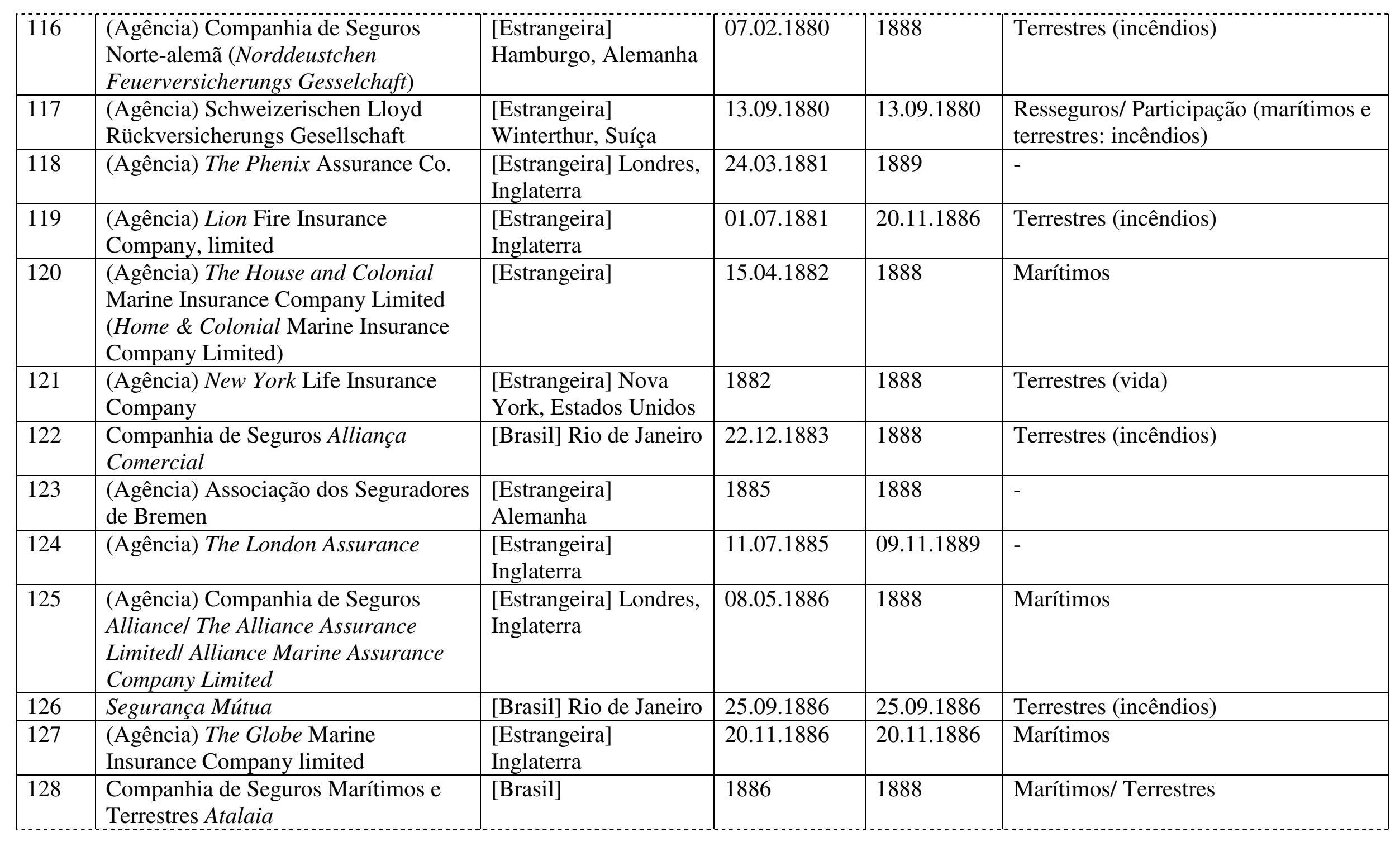




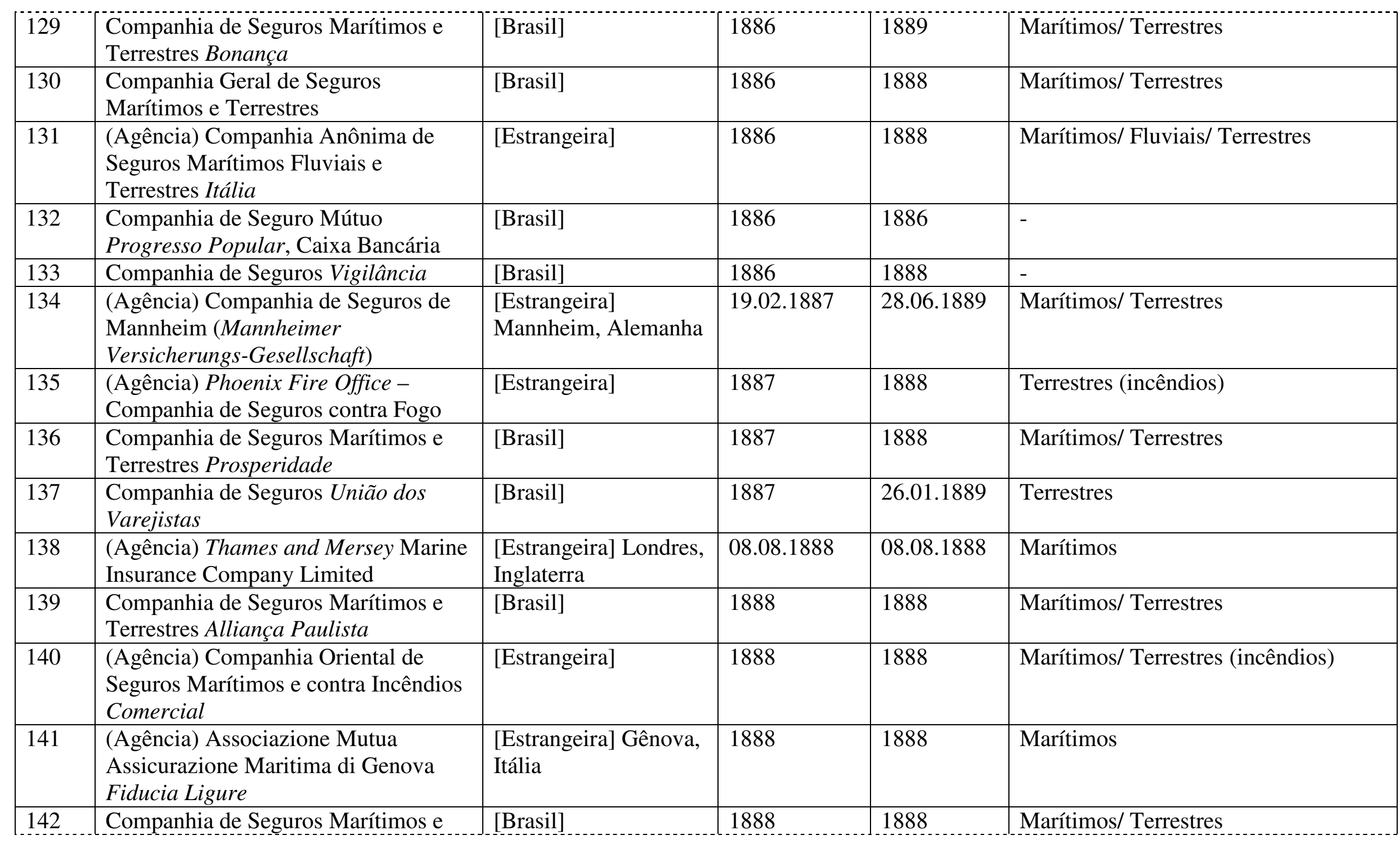




\begin{tabular}{|c|c|c|c|c|c|}
\hline & Terrestres Indemnizadora & & & & \\
\hline 143 & $\begin{array}{l}\text { Companhia de Seguro Mútuo } \\
\text { Esperança }\end{array}$ & [Brasil] Rio de Janeiro & 19.10 .1889 & 19.10 .1889 & Terrestres (incêndios) \\
\hline
\end{tabular}

Fonte: BRASIL. Poder Legislativo. Câmara dos Deputados, Coleção das Leis do Império do Brasil (1808-1889); Almanak administrativo, mercantil e industrial do Rio de Janeiro - Almanak Laemmert (1844-1889); BRASIL. Ministério do Trabalho, Indústria e Comércio, Sociedades Mercantis autorizadas a funcionar no Brasil (1808-1946); BRASIL. Conselho de Estado, Seção de Fazenda, Imperiaes Resoluções do Conselho de Estado na Seção de Fazenda (1842-1889); BRASIL. Ministério da Indústria e do Comércio. Instituto de Resseguros do Brasil, Coletânea da legislação brasileira de seguros (De 29 de abril de 1828 a 1 de abril de 1947); BRASIL. Ministério da Indústria e do Comércio. Instituto de Resseguros do Brasil, Ementário da legislação brasileira de seguros (1808 a 1973); CAROATA, José Próspero Jeová da Silva, Imperiaes resoluções tomadas sobre consultas da secção de justiça do conselho de estado; O Direito: revista de legislação, doutrina e jurisprudência; Acervo Judiciário do Arquivo Nacional do Rio de Janeiro; PINHEIRO, Francisco Baptista Marques. Jurisprudencia Commercial; MAFRA, Manoel da Silva. Jurisprudencia dos tribunaes; BOHRER, Saulo Santiago, "Interesses Seguros": as companhias de seguro e a Provedoria dos Seguros do Rio de Janeiro (1810-1831); CASTRO, Ana Célia. As Empresas estrangeiras no Brasil: 1860-1913; FLORENTINO, Manolo. Em Costas negras: uma história do tráfico de escravos entre a África e o Rio de Janeiro (séculos XVIII e XIX). 


\begin{abstract}
ANEXO 3:
Considerações ao Quadro Companhias de Seguros em funcionamento na Província do Rio de Janeiro (1808-1889) (Anexo 2)
\end{abstract}

Apresentamos a seguir algumas considerações acerca da elaboração do Quadro Companhias de Seguros em funcionamento na Província do Rio de Janeiro (1808-1889).

Elas acabaram por se tornar necessárias porque, no decurso de um trabalho meticuloso como este, a coleta e a posterior organização de uma grande quantidade de dados provenientes de fontes diversas provocaram o aparecimento de algumas dúvidas que, como será visto, são basicamente os problemas surgidos em decorrência da identificação do conjunto das seguradoras estabelecidas na praça comercial da província, ou das que ali funcionaram por intermédio de seus agentes.

Precisávamos descobrir como lidar com algumas situações protagonizadas pelas companhias de seguros, relativamente frequentes durante suas respectivas existências no comércio. As informações colhidas, e que porventura denunciassem algumas manobras mercantis como foram os casos, por exemplo, das liquidações, das fusões entre as seguradoras, das mudanças de nomes, etc., demandaram certo olhar cuidadoso, pois, do contrário, facilmente poderíamos listar mais de uma vez a mesma companhia, o que provavelmente iria prejudicar o cômputo que serviu às análises elaboradas no corpo da dissertação.

Tentamos evitar que o Quadro saísse carregado desses enganos. Além dos problemas com que fomos nos deparando durante o percurso, a seguir vão também as reflexões que justificaram a opção por esta ou aquela solução. Assim, ao mesmo tempo em que mantivemos, em alguma medida, certa uniformidade para as soluções tiradas de dúvidas semelhantes, também forneceríamos subsídios para pesquisas futuras que se dedicassem a aperfeiçoar essa listagem das companhias de seguros em funcionamento na província do Rio de Janeiro durante o século XIX. Foram reflexões amparadas pelas informações e pelos indícios que pudemos extrair das fontes consultadas. Obviamente, e assim esperamos, futuras reflexões, amparadas por informações provenientes destas e/ ou de fontes diferentes, poderão resultar no levantamento de outros problemas e na busca por novas respostas.

Optamos por dividir estas considerações em seis tópicos: o primeiro consiste em dar conta dos casos de liquidações e fusões verificados entre as companhias de seguros que 
operaram na praça mercantil do Rio de Janeiro no oitocentos; o segundo comporta os casos de mudanças de nomes dessas mesmas empresas; o terceiro, os casos em que houve dúvidas quanto à identidades dessas seguradoras; a seguir, inserimos os casos de seguradoras estrangeiras que não foram computadas no Quadro devido à falta de informação sobre os locais em que operavam seus negócios; o quinto tópico diz respeito a dois casos de empresas que tiveram autorizadas suas respectivas incorporações, mas que não dispusemos de notícias que nos confirmassem se esses feitos foram levados a cabo ou não; e, por último, os problemas constatados durante a coleta dos dados e que poderiam merecer alguma apreciação, mas que não puderam ser classificados em nenhum dos itens anteriores. Todos os tópicos vão subdivididos em subtópicos, por onde vão relatados os casos particulares e as soluções encontradas para cada um deles.

Além disso, depois do nome de cada seguradora optamos por colocar, entre parênteses, o número correspondente às suas respectivas posições no Quadro Companhias de Seguros em funcionamento na Província do Rio de Janeiro (1808-1889), que constitui o Anexo 2 desta dissertação. Ao procedermos dessa forma, talvez tenhamos facilitado o acompanhamento que se queira fazer de cada caso, pois maiores informações de cada empresa poderiam ser acessadas mais rapidamente e, portanto, possibilitaria, em alguma medida, que o interessado contrapusesse as informações por si mesmo e, assim, encontrasse soluções diferentes para um ou mais casos.

Os casos, a seguir vão todos eles:

1) Casos de liquidações de companhias de seguros ou de fusões entre elas:

1.1 Houve casos em que algumas companhias de seguros passavam por um período de liquidação para posteriormente serem incorporadas por outras. E casos em que simplesmente uma e outra se fundiam e passavam a ser denominadas por um só nome. Em regra, cada uma das empresas, a antiga e a nova, está relacionada num campo individual do Quadro. Porém, para facilitar o contato com essas informações, após o nome da companhia que sobreviveu indicamos, entre parênteses, alguma notícia do ocorrido. 


\subsection{Reunião dos seguradores particulares de riscos marítimos (18)/ Companhia}

de Seguros Marítimos Seguridade (40): a primeira delas liquidou-se para que desse lugar à segunda. Ela funcionou pelo menos de 1845 a 1855 , e a nova companhia de 1856 a 1864. Ambas tinham conservado o negociante Carlos Le Blon nos seus respectivos quadros diretivos.

1.3 Phenix Fluminense (16)/ Argos Fluminense (20): A Phenix, que funcionava desde 1843, incorporou-se na Argos em 1854/1855, como assim noticiou o Almanak Laemmert na sua publicação de 1855 (p. 360-361). Esta última companhia já atuava no mercado desde 1846 e, pelo que consta do último número do Almanak (o de 1889, correspondente ao ano anterior), ainda estaria funcionando quando o Império estava se pondo.

1.4 Companhia de Seguros Regeneração (17)/ Companhia de Seguros Marítimos Nova Regeneração (53): a publicação de 1861 do Almanak Laemmert afirmou que "A Companhia Regeneração [em funcionamento desde 1844] acha-se em liquidação, e a nova companhia foi instalada em 4 de Outubro de 1860" (p. 395). Fora uma observação feita no texto da chamada da Companhia Nova Regeneração, ao que tudo indica a nova companhia mencionada na citação. Ela foi autorizada a funcionar pelo Decreto $\mathrm{n}^{\circ} 2.645$, de 18 de setembro de 1860, o mesmo documento que aprovou seus estatutos, que em seu artigo $7^{\circ}$ dizia que "A Companhia começará a trabalhar no dia $1^{\circ}$ de Outubro futuro, ou quando vier sua aprovação, e durará por 20 anos consecutivos (...)".

2) Casos de mudanças de nome:

2.1 Nos casos em que algumas companhias de seguros peticionaram ao Poder Executivo exigindo a aprovação de uma denominação distinta daquela com que vinham atuando no mercado, consideramos serem a mesma companhia ao longo do tempo. Para facilitar o contato com essas informações, entre um 
nome e outro, que vão no mesmo campo, colocamos uma barra para separálos.

\subsection{Companhia de Seguros Marítimos e Terrestres/ Companhia de Seguro} Marítimo Santa Cruz (41): o Decreto n ${ }^{\circ} 1.724$, de 16 de fevereiro de 1856, aprovou os estatutos da seguradora que foi fundada sob a denominação de Companhia de Seguros Marítimos e Terrestres. Cerca de quatro anos depois, outro Decreto, o de $\mathrm{n}^{\mathrm{o}} 2.572$, de 14 de abril de 1860, em seu artigo $1^{\circ}$, mudava seu nome para Companhia de Seguro Marítimo Santa Cruz, autorizada a efetuar somente contratos que envolviam os riscos provenientes do transporte por mar. Apesar da restrição a seus negócios, cremos não se tratar de nova companhia. A última notícia que tivemos da Santa Cruz dizia que ela estivera em liquidação no ano de $1862^{194}$.

2.3 Companhia de Seguros Marítimos e Terrestres Feliz Lembrançal Companhia Geral de Seguros União (44): o Decreto no 4.515, de 28 de abril de 1870, aprovou o pedido de mudança de nome da Companhia Geral de Seguros Feliz Lembrança, substituindo a expressão "Feliz Lembrança" por "União". Porém, há que se atentar para que não haja confusão entre esta União e a que teve seus estatutos aprovados pelo Decreto ${ }^{\circ} 6.058$, de 14 de dezembro de 1875. Aquela foi uma sociedade anônima, e esta, uma associação mútua (vide companhia seguradora correspondente ao $\mathrm{n}^{\circ} 99$ do Quadro).

\subsection{Companhia de Seguros Marítimos Recuperadoral Companhia de Seguros} Marítimos e Terrestres Fidelidade (11): Decreto $\mathrm{n}^{\mathrm{o}}$ 791, de 30 de maio de 1851, autorizou a incorporação e aprovou os estatutos da companhia sob a denominação de Recuperadora. Alguns anos mais tarde, em 6 de fevereiro de 1858, o Decreto n 2.103 aprovou "os novos Estatutos organizados para a Companhia Recuperadora, debaixo do nome de - Fidelidade". Somente pela leitura desses documentos ainda nos restaria alguma dúvida a respeito da individualidade da seguradora: se continuariam a ser uma só, ou se seriam

\footnotetext{
${ }^{194}$ Cf. Almanak Laemmert, 1863, p. 408.
} 
duas após o ano de 1858. Porém, há dois indícios de que estamos diante de uma e mesma companhia de seguro, apesar do nome Fidelidade ter sido autorizado à negociação sobre mais riscos (marítimos e terrestres) que seu antecessor. O primeiro deles pode ser encontrado na página 6 do documento Sociedades Mercantis autorizadas a funcionar no Brasil (1808-1946), onde se lê que a Fidelidade é a "nova denominação da Companhia Recuperadora" 195 . Por outro lado, pudemos verificar certa continuidade das pessoas que compuseram o quadro administrativo da companhia na época em que optou pela mudança de seu nome. O Almanak Laemmert nos informa, por exemplo, que José Dyonisio de Mello e Faro e Manoel da Motta Macedo eram os diretores em 1857 e continuaram a compor a direção até 1860. E que Pedro Augusto Vieira, o Caixa da companhia às vésperas de sua nova denominação, ainda estaria dentre os diretores pelos três anos seguintes $^{196}$.

3) Casos em que houve dúvidas quanto à identidade das companhias de seguros:

\subsection{Agents of Underwriters of the City of New York (38)/ Companhias de} Seguros Marítimos de New York/ Agência das Companhias de Seguros Marítimos de Nova York, Estados Unidos: trata-se de três nomes constantes das chamadas do Almanak Laemmert. Consideramos que todas seriam na verdade as mesmas seguradoras, apesar de serem anunciadas sob denominações distintas, em períodos diferentes, apresentando os nomes de seus agentes sem que houvesse coincidência entre eles, e só sendo especificada a especialidade dos riscos segurados pelas duas últimas. Em primeiro lugar, as companhias são chamadas nas publicações por nomes muito semelhantes entre si, muito embora esteja um grafado em língua estrangeira e a outro se acrescente a palavra "Agência" no início e o país de

\footnotetext{
${ }^{195}$ Cf. os dados completos do documento nas Referências a esta dissertação.

${ }^{196}$ Cf. Almanak Laemmert, 1858, p. 421; 1859, p. 446; 1860, p. 450; 1861, p. 396. Estas datas correspondem aos anos da publicação de cada número do periódico e, portanto, devemos considerar que um número publicado trazia informações referentes ao ano que o antecedeu. Os anos que aqui vão conferidos foram escolhidos não por acaso, mas porque representaram o período no qual se deu a transição do nome Recuperadora para Fidelidade. Os nomes de Manoel da Mota Macedo e de Pedro Augusto Vieira seguiram existindo dentre os nomes que compuseram o quadro diretivo da companhia por anos a fio.
} 
origem ao final. Por isso, neste caso as diferentes denominações não podem configurar um critério definitivo quando pretendemos individualizá-las, tampouco os anos em que foram publicadas nos convencem de que na realidade deveriam ser tratadas como companhias distintas. A primeira delas, Agents of Underwriters of the City of New York, foi anunciada uma única vez, na publicação referente ao ano de 1855. Passa-se um ano até que os anúncios da segunda comecem a constar dos números correspondentes ao período de 1857-1862. E, após o espaço de mais um ano, vêem as publicações nas quais podem ser encontrados os anúncios da terceira, que se referem aos anos 1864-1865. Ao que parece, os anúncios eram enviados para os editores do Almanak por algum responsável pelas companhias e, como podemos perceber que os agentes de uma e outra nunca foram os mesmos, os espaços temporais entre as chamadas de uma e outra na verdade não chegam a interromper a continuidade da atuação delas no mercado carioca, mas antes podem denotar a ocorrência de alguns imprevistos na administração das seguradoras ou na organização dos agentes. O anúncio das Companhias de Seguros Marítimos de New York referente ao ano de 1862, por exemplo, informa-nos que seus agentes (Filgueiras, Sands \& Cia.) se encontravam em liquidação, o que poderia muito bem explicar a ausência do anúncio na publicação referente ao ano seguinte, bem como o novo nome do agente que vai junto com a chamada da Agência das Companhias de Seguros Marítimos de Nova York, Estados Unidos na publicação de 1865 (portanto, correspondente ao ano de 1864).

3.2 Companhias de Seguros Marítimos de Gênova (55)/ Agência das Companhias de Seguros Marítimos de Gênova "La Rinnosazione” $e$ "Mutua Assicurazione"/ Companhias de Seguros de Gênoval Associazione Mutua Assicurazione Maritima di Genova Fiducia Ligure (141): os quatro nomes constam de chamadas do Almanak Laemmert. Consideramos as três primeiras como sendo a mesma agência de companhias seguradoras. Dentre elas não houve aparição simultânea num mesmo número do periódico. Os nomes das duas primeiras vão muito semelhantes nas páginas do Almanak, diferenciando-se apenas pela colocação da palavra "Agência" e pela 
especificação dos nomes das companhias por ela representadas, no início e ao fim do segundo nome. As duas primeiras parecem ser as mesmas apesar de um intervalo razoável de tempo (cerca de cinco anos) separar o último anúncio das Companhias (1861-1862) e o surgimento da Agência (18681873), o que não ocorre entre esta e a seguinte, pois a terceira (1874-1888) é chamada pela primeira vez logo no ano imediato à última aparição do nome da segunda. Percebemos que o espaço temporal mencionado coincide com o período em que a praça mercantil do Rio de janeiro foi acometida por uma forte crise financeira (conhecida como crise de 1864), o que pode ter motivado o agente a conter os gastos com anúncios, ou mesmo o que pode ter provocado a suspensão dos negócios por parte das próprias companhias. Além do mais, o terceiro nome, Companhias de Seguros de Gênova, guarda muita semelhança com o primeiro e, por conseguinte, com o segundo. $\mathrm{O}$ fato de estar grafado no singular pode ser um indicativo da inconstância sempre presente nas relações das companhias seguradoras com os agentes que as representariam em outras praças. E de igual modo o fato de nele não constar a especialidade dos riscos segurados - marítimos - não pode ser tomado como critério definitivo para individualizá-lo. Por outro lado, consideramos a última companhia - Associazione Mutua Assicurazione Maritima di Genova Fiducia Ligure - como sendo uma seguradora à parte das demais. Pois, além de seu nome se distanciar das denominações anteriores, há um anúncio a ela referente na mesma publicação (a do ano de 1889, que correspondia ao ano anterior) em que vai uma chamada para a Companhia de Seguros de Gênova.

\subsection{Companhia de Seguros Marítimos e Terrestres de São Salvador de Campos/} Companhia de Seguros de São Salvador de Campos (68): trata-se de duas denominações, porém referentes a uma só companhia de seguros. Ambas constavam das chamadas do Almanak Laemmert, sendo que a primeira somente apareceu na publicação referente ao ano de 1874 , e a segunda a partir de 1875 até o último número do periódico (o de 1889, no qual iam as notícias do ano anterior). A dúvida quanto à individualidade das companhias emergiu em decorrência da leve diferença entre os nomes. $\mathrm{O}$ 
primeiro revela os ramos do seguro em que a seguradora atuaria, ao contrário do segundo. Mas, por pelo menos duas razões decidimos que na realidade se trata da mesma empresa. Em primeiro lugar, apesar de inicialmente a companhia segurar somente os riscos provenientes do mar (conforme o Decreto $\mathrm{n}^{\circ} 4.318$, de 13 de janeiro de 1869, que concedeu autorização para funcionar e aprovou seus estatutos), em 1874 o Decreto $n^{\circ}$ 5.710 de 12 de agosto, aprovou as modificações no artigo $1^{\circ}$ de seus estatutos para que os negócios por ela contratados pudessem recair sobre os riscos terrestres. Ou seja, quando a São Salvador de Campos aparecia pela primeira vez nas páginas do Almanak ela já estaria autorizada a atuar nesses dois ramos de seguros, o que não desmente o seu nome. Parece-nos que a denominação genérica da companhia (o segundo nome) deve ser considerada caso a caso quando a intenção for a descoberta de sua verdadeira identidade que, neste caso, são coincidentes. A segunda evidência parece ter confirmado nossa decisão. $O$ fato é que o primeiro anúncio da seguradora, o de 1874, traz consigo os nomes das pessoas que compunham seu quadro administrativo - Conselho Fiscal: Presidente, $1^{\circ}$ Secretário e $2^{\circ}$ Secretário; Diretoria: Caixa, Guarda-Livros, Ajudante -, ao que se segue um período em que somente eram mencionados seus correspondentes na praça do Rio de Janeiro (1875 a 1882). Em 1883, 1884 e 1885, novamente vão publicados os nomes que compunham a Diretoria e Conselho Fiscal, e aí pudemos verificar a permanência de alguns negociantes apesar de passada quase uma década em que estavam à frente da seguradora. Foi o que ocorreu com José Alves da Torre, Gustavo Ferreira dos Santos e Antonio José Ferreira Martins que, em 1874 e de 1883-1885, continuariam com seus nomes vinculados à Diretoria; e Joaquim Pereira de Miranda que, pelo mesmo período, participaria do Conselho Fiscal da companhia.

\subsection{Companhia de Seguros Tranquilidade (5)/ Companhia de Seguros}

Tranquilidade (39): a dúvida que recaiu sobre o nome "Tranquilidade" deveu-se ao grande intervalo de tempo verificado entre as datas coletadas de fontes diversas. A primeira notícia que temos de uma companhia com esse 
nome é a que nos fornece Saulo Santiago Bohrer em sua dissertação de mestrado ("Interesses Seguros": as companhias de seguro e a Provedoria dos Seguros do Rio de Janeiro (1810-1831)): na tabela de $\mathrm{n}^{\circ} 6$ intitulada “Relação das Companhias de Seguro entre 1810 e 1831" (p. 56), o autor menciona que fora fundada em 1818. Sabemos que provavelmente esta mesma Tranquilidade (5) estaria em funcionamento nos anos de 1825, pois fora ré "num processo aberto por Joaquim Ribeiro de Brito", conforme nos informa Manolo Florentino ${ }^{197}$; em 1827, pois assina um parecer sobre a conveniência da criação da Associação de Seguros Mútuos, e em 1834, ano em que configurou o pólo passivo de um processo (juntamente com as seguradoras Providente (2), Bom Conceito e Concórdia (10)) movido por José Alves Barbosa e localizado dentre os documentos que compõem o Fundo da Relação do Rio de Janeiro, no Arquivo Nacional ${ }^{198}$. As outras duas datas referentes a uma tal Companhia de Seguros Tranquilidade (39) são fornecidas pelos atos do Poder Executivo: o primeiro deles, o Decreto $\mathrm{n}^{\circ}$ 1.669, de 7 de novembro de 1855, "Autoriza a incorporação, e aprova os Estatutos da Companhia de seguros de vida, estabelecida nesta Corte sob a denominação de - Tranquilidade"; e o segundo, outro Decreto, o de $n^{\circ}$ 2.101, de 6 de fevereiro de 1858, aprovou "as alterações e adições propostas aos Estatutos da Companhia de seguros de vida - Tranquilidade". Estes dois decretos mencionam que a companhia a que se referem somente estaria autorizada a negociar sobre os riscos sobre a vida (seja de escravos ou de pessoa livre), enquanto que as noticiadas por Bohrer e pelo processo, ao que tudo indica, atuavam no ramos dos seguros marítimos. Consideramos que estaríamos diante de duas companhias de seguro com o mesmo nome. A primeira Tranquilidade (5) fora fundada em 1818, e estaria em funcionamento em 1827 e 1834, data esta em que obtivemos a última notícia de sua existência. A segunda (39), por sua vez, seria a incorporada pelo Decreto de 1855, cujos estatutos foram modificados três anos mais tarde. Uma e outra atuavam em ramos de seguros diferentes (marítimos, a

\footnotetext{
${ }^{197}$ Cf. FlORENTINO, Manolo, Em Costas negras, p. 278, nota 8. Consta que sua fonte foi um documento localizado na Caixa 433, Pacote 2, do Fundo da Junta do Comércio, no Arquivo Nacional.

${ }_{198}$ Para a participação da companhia no processo de autorização para o funcionamento da Associação de Seguros Mútuos, cf. BOHRER, Saulo Santiago, O “seguro” morreu de velho, p. 10-13.
} 
primeira e; a segunda, terrestres), sendo que os Decretos nenhum fazem menção à pré-existência de uma companhia anterior.

3.5 Companhia de Seguros Boa Fé: existia uma companhia com esse nome na Bahia, criada pelo Alvará de 24 de fevereiro de 1808, portanto poucos dias após o aportamento de D. João na capitania. Mas, deveríamos procurar saber se havia uma companhia seguradora, com esse mesmo nome, estabelecida na cidade do Rio de Janeiro. A dúvida foi gerada pela desarmonia das informações verificadas em dois textos de Saulo Santiago Bohrer. No primeiro deles - O "seguro" morreu de velho: a Associação dos Seguros Mútuos Brasileiros na manutenção dos interesses dos negociantes no Rio de Janeiro -, em nota na página 9, dá a entender que uma companhia seguradora denominada Boa Fé fora criada no Rio de Janeiro em 1827. No segundo texto, sua dissertação de mestrado "Interesses Seguros": as companhias de seguro e a Provedoria dos Seguros do Rio de Janeiro (1810-1831) -, a tabela de $\mathrm{n}^{\circ} 6$ intitulada "Relação das Companhias de Seguro entre 1810 e 1831” (p. 56) não indica a existência de qualquer companhia com este nome. Assim como fizemos para a Companhia de Seguros Tranquilidade, optamos por nos orientar de acordo com o que vai à dita tabela de $\mathrm{n}^{\circ} 6$, constante do último texto do autor. Portanto, consideramos que não existia uma companhia de seguro cujo nome fosse Boa Fé estabelecida no Rio de Janeiro, muito embora desconhecermos se a homônima baiana chegou a negociar na praça carioca.

3.6 Companhia de Seguros Alliance (125)/ Companhia de Seguros Alliance British and Foreign Life and Fire Assurancel Alliance Marine Assurance Company Limited (125)/ The Alliance Assurance Limited (125)/ The British and Foreign Life and Fire Assurance Alliance (70)/ The Alliance British and Foreign Life and Fire Assurance (70): os três primeiros nomes constam das páginas do Almanak Laemmert, os três últimos estão arrolados no documento Sociedades Mercantis autorizadas a funcionar no Brasil (18081946), sendo que o primeiro e o último também constam da Coleção das Leis do Império do Brasil (1808-1889). São seis denominações semelhantes 
e a variedade das fontes em que aparecem pode contribuir para alguns desencontros em torno das grafias dos nomes. Alguns deles são notoriamente muito semelhantes, diferenciando-se apenas pela localização da palavra "Alliance", se no início ou no fim, ou pela especificidade do ramo empresarial, como é o caso do segundo, quinto e sexto. Consideramos que todos eles devem ser atribuídos a uma única seguradora, muito embora trabalhos de outros autores tenham notado o contrário ${ }^{199}$. Há um segundo grupo de nomes que nos provocou a maiores reflexões. O primeiro nome da relação, Companhia de Seguros Alliance, consta das páginas de duas fontes: do Almanak Laemmert, e da Coleção das Leis do Império do Brasil (18081889). Porém, apesar da identidade verificada, na verdade estariam escondendo duas companhias de seguros distintas. Explicamos. Em primeiro lugar, uma Companhia de Seguros Alliance seria correspondente à relacionada por outra fonte, Sociedades Mercantis autorizadas a funcionar no Brasil (1808-1946), porém com o nome mantido no idioma original. Ou seja, a Alliance revelada pela Coleção das Leis do Império do Brasil (18081889) seria a mesma que a The Alliance Assurance Limited (125). Em segundo lugar, a outra Companhia de Seguros Alliance guarda alguma relação com a Companhia de Seguros Alliance British and Foreign Life and Fire Assurance, ambas constantes das chamadas do Almanak Laemmert. Apesar do periódico ter publicado no ano de 1871 dois anúncios cada um referente a uma dessas duas denominações, em páginas separadas até, há uma forte razão para considerarmos que na verdade estaríamos diante da mesma companhia, e essa razão é a ocorrência de eventuais erros editoriais. O anúncio referente à Companhia de Seguros Alliance (p. 401) é do tipo mais simples, em que vai exposto o nome da Cia., o nome e o endereço do agente (Pacheco \& Hill, rua Direita $\mathrm{n}^{\circ} 100$ ); o anúncio da Companhia de Seguros Alliance British and Foreign Life and Fire Assurance (p. 400) traz um texto mais completo, em que além do nome completo da empresa, é acrescentado o capital, o nome e o endereço do agente (Pacheco \& Hill, rua

199 Cf. CASTRO, Ana Célia. As Empresas estrangeiras no Brasil: 1860-1913, p. 161, dentre outros. Na tabela apresentada em anexo à sua dissertação de mestrado, a autora reconhece que os nomes The Alliance British and Foreign Life and Fire Assurance e The British and Foreign Life and Fire Assurance Alliance devem ser atribuídos a companhias distintas, muito embora sejam da mesma nacionalidade inglesa, estabelecidas na mesma cidade de Londres, e seguradoras dos mesmos riscos terrestres (incêndios). 
Primeiro de Março $\mathrm{n}^{\circ}$ 100). O que podemos perceber é que o agente das duas seguradoras é o mesmo, e apesar dos nomes das ruas serem diferentes, poderiam estar nos remetendo ao mesmo local. Ao que parece, por volta do ano de 1870, das duas alternativas uma ocorreu: ou algumas companhias de seguros mudaram seus escritórios da rua Direita para a Primeiro de Março, ou se houve mudança foi a do próprio nome da rua. $\mathrm{O}$ fato é que a partir de 1870/1871 pelo menos quatro endereços de seguradoras mudaram, porém os números dos respectivos prédios foram conservados, o que nos leva a creditar na segunda hipótese. Foram os casos, por exemplo, da Companhia de Seguros Marítimos Nova Permanente (12) (de rua Direita $\mathrm{n}^{\circ} 43,1^{\circ}$ andar, para rua Primeiro de Março $\left.\mathrm{n}^{\circ} 43\right)$; Companhia de Seguros contra fogo Argos Fluminense (20) (Praça do Comércio, escritório 08, para rua Primeiro de Março, escritório 08); Companhia de Seguros Marítimos e Terrestres Garantia 62) (de rua Direita $\mathrm{n}^{\circ}$ 47, para rua Primeiro de Março $\mathrm{n}^{\circ}$ 47); e, por último, a Agência das Companhias de Seguros Marítimos de Gênova (55) (de rua Direita $n^{\circ} 105$, sobrado, para rua Primeiro de Março $n^{\circ} 105$, sobrado). Todo esse imbróglio poderia muito bem estar indicando que os editores do Almanak receberam o novo anúncio enviado pelo agente Pacheco \& Hill, mas se esqueceram de anular o antigo. Os erros que iam junto com a publicação não seriam raros, conforme os próprios editores reafirmavam ano a ano nos prólogos que antecediam cada número do periódico. Mas, conjecturas à parte, as coincidências não param por aí. Ainda temos de considerar que a data da última aparição da Companhia de Seguros Alliance nas chamadas do Almanak corresponde à mesma data em que começaram os anúncios da Companhia de Seguros Alliance British and Foreign Life and Fire Assurance. Ou seja, a publicação de 1871 (portanto referente ao ano de 1870), ao que tudo indica, foi um divisor de águas para o uso do nome da companhia, mas não para sua continuidade no mercado segurador carioca. Ainda temos de considerar o terceiro nome destacado. A seguradora Alliance Marine Assurance Company Limited (125), ao que tudo indica, é a mesma que a Companhia de Seguros Alliance (125)/ The Alliance Assurance Limited (125). Todas seguram contra riscos marítimos, e todas são de Londres (Inglaterra). Sua primeira aparição nas páginas do 
Almanak Laemmert foi nos anúncios da publicação de 1887, o que quer dizer que ela já atuava no mercado carioca no ano anterior, 1886, mesma data do Decreto que autorizou o estabelecimento de suas agências no Império do Brasil.

\subsection{Companhia de Seguros Perseverança de Campos/ Companhia de Seguros} Marítimos e Terrestres e de Escravos Perseverança: foram dois nomes que apareceram nas páginas do Almanak Laemmert. Consideramos que ambos correspondem à mesma seguradora, por pelo menos dois motivos. Em primeiro lugar, o segundo nome aparece somente em um número do periódico (publicação de 1875), e nos acréscimos (p. 289), dando informação do capital e do quadro diretivo. Dentre os nomes das pessoas que compuseram a direção da companhia, alguns eram coincidentes com os apresentados no anúncio de 1888 referente ao primeiro nome, como é o caso de Jeronymo Joaquim de Oliveira. Aí o segundo motivo. No Quadro, no entanto, a empresa aparecerá sob a denominação de Companhia de Seguros Perseverança (77).

\subsection{Sociedade Transatlântica de Seguros contra o fogo (85)/ Companhia} Transatlântica de Seguros contra o fogo (85)/ Companhia Transatlântica de Seguros Marítimos e Terrestres (86): os dois primeiros nomes constam das chamadas do Almanak Laemmert; o terceiro, de um decreto encontrado na Coleção das Leis do Império do Brasil (1808-1889). Esta última fonte também guarda um decreto que autorizou o funcionamento da Sociedade. Consideramos as duas primeiras denominações como acusativas da existência da mesma companhia seguradora. Em primeiro lugar, porque os termos 'Sociedade' e 'Companhia' que precedem cada um dos nomes não necessariamente significavam conceitos completamente distintos, pelo menos por volta de meados do século $\mathrm{XIX}^{200}$. Em segundo lugar, ambas as companhias estariam estabelecidas em Hamburgo (Alemanha), e segurariam

\footnotetext{
200 “Companhia, termo jurídico-comercial: antigamente, e civilmente falando é sinônimo de sociedade (...). Ainda que hoje se possa dizer companhia por sociedade, todavia, estritamente falando, companhia é a associação incorporada por carta ou alvará de instituição concedida pelo Governo", cf. BORGES, José Ferreira, Diccionario Juridico-Commercial, p. 91. Ver entrada "Companhia”.
} 
os mesmos riscos terrestres (incêndios). Em terceiro lugar, a única, e portanto a última, data em que a Sociedade Transatlântica de Seguros contra o fogo (85) apareceu nas páginas do Almanak foi na publicação de 1874 (correspondente às informações recolhidas até o término do ano anterior, 1873). O número publicado em 1875 já chamava pelo nome da Companhia Transatlântica de Seguros contra o fogo (85), o que bem poderia significar a continuidade das atividades da seguradora na praça do Rio de Janeiro, apesar de mudado o nome do agente. Já a Companhia Transatlântica de Seguros Marítimos e Terrestres (86) consideramos se tratar de uma seguradora distinta da anteriormente apresentada. Isso porque, além de contratarem sobre riscos provenientes de mar e de terra, fora estabelecida em Berlim (Alemanha).

\subsection{Companhia de Seguro Mútuo Progresso Popular, Caixa Bancária (132)/} Companhia de Seguro Mútuo Progressol Associação de Seguro Mútuo Progresso (110): as duas primeiras denominações foram conhecidas pelos anúncios publicados no Almanak Laemmert; e a terceira, por um decreto constante da Coleção das Leis do Império do Brasil (1808-1889). Ao que tudo indica, os dois últimos nomes identificam a mesma seguradora, apesar de estarem revestidos de estatutos jurídicos diferentes ('Companhia' para um, 'Associação' para outro). O anúncio da Companhia de Seguro Mútuo Progresso publicado no ano de 1889 afirmou que esta seguradora fora autorizada a funcionar no Império em 1877, ano coincidente ao da publicação do Decreto $n^{\circ}$ 6.613, de 4 de julho, que aprovou os estatutos da Associação de Seguro Mútuo Progresso (110). Já a Companhia de Seguro Mútuo Progresso Popular, Caixa Bancária (132), foi considerada como sendo uma empresa à parte, pois, além de ser caracterizada como Caixa, o nome leva um qualificativo que inexiste na grafia dos outros dois ('Popular').

\subsection{A Equitativa Brasileira (107)/ Companhia de Seguros Equitatival Equitable}

Life Insurance (112): o primeiro e o último nomes constam da Coleção das Leis do Império do Brasil (1808-1889); o segundo aparece dentre os 
anúncios do Almanak Laemmert. Consideramos que as duas últimas denominações referem-se à mesma seguradora. Não só porque a chamada constante da publicação de 1883 faz referência a uma tal "The Equitable", mas porque tanto uma como a outra denominação dizem respeito a certa companhia nova iorquina, que contrata sobre os riscos de vida. A Equitativa Brasileira (107) foi considerada uma companhia distinta. Sua sede foi mesmo na cidade do Rio de Janeiro, portanto ao contrário da seguradora anteriormente apresentada, era nacional.

\subsection{Companhia de Seguro Mútuo contra o fogo Alliança (57)/ Companhia de} Seguros Alliança (115): ambas as denominações constam tanto do Almanak Laemmert como da Coleção das Leis do Império do Brasil (1808-1889). Mas consideramos que cada uma delas refere-se a uma companhia seguradora específica. A primeira companhia segura somente os riscos de incêndios; e a segunda todos os riscos provenientes da navegação marítima, fluvial, ou imanentes aos empreendimentos terrestres.

\subsection{The House and Colonial Marine Insurance Company (120)/ Home \&} Colonial Marine Insurance Company Limited: pela semelhança mantida entre os dois nomes, consideramos como sendo referentes a uma única companhia seguradora.

\subsection{The Liverpool and London Insurance Company (64)/ The Liverpool and} London and Globe Insurance Company (64): consideramos ambas as denominações como sendo reveladores da mesma companhia seguradora. $\mathrm{O}$ primeiro documento localizado, e que forneceu notícias da existência da companhia, foi o Decreto $\mathrm{n}^{\circ} 3.673$, de 22 de junho de 1866. Referido diploma concedia a autorização para o funcionamento da empresa e para que estabelecesse "uma agência na capital da Província da Bahia", e fez referência somente ao primeiro nome, o que não vai a expressão "and Globe" em sua grafia. O segundo nome, contudo, constaria de dois outros decretos: o de $\mathrm{n}^{\mathrm{o}} 3.788$, de 24 de janeiro de 1867, que autorizou a companhia a "estabelecer uma agência na Capital da Província de 
Pernambuco"; e o de $n^{\circ} 4.177$, de 6 de maio de 1868, que permitiu a instalação de uma agência na capital da Província do Rio de Janeiro. Cada uma dessas autorizações para a instalação de novas agências no território do Império seria seguida de uma exigência: cada uma dessas agências deveria funcionar sob as condições estipuladas no primeiro Decreto de $\mathrm{n}^{\circ} 3.673$. Esse fato, somado à ausência de alguma notícia referente a incorporações ou fusões entre companhias, contribuiu para considerarmos que na verdade ambos os nomes faziam referência a existência de apenas uma empresa seguradora.

3.14 Companhia de Seguros sobre a Vida dos Escravos Prosperidade (19)/ Companhia de Seguros Marítimos e Terrestres Prosperidade (136): uma e outra companhia foram conhecidas das páginas do Almanak Laemmert. A primeira delas foi anunciada uma única vez, na publicação de 1846 (portanto, correspondente às notícias do ano anterior). Cerca de quarenta anos depois é que o nome da segunda seguradora foi chamado pelo periódico (publicações de 1888 e 1889). Por esses motivos, quais sejam o distanciamento temporal entre uma e outra aparição, bem como a diferença que há entre as denominações (o que denuncia de igual modo a especificidade de cada uma no que diz respeito aos riscos segurados), consideramos que, apesar da coincidência do nome Prosperidade, trata-se na verdade de duas seguradoras distintas.

4) Casos em que não foram encontradas informações que confirmassem a atuação de algumas seguradoras estrangeiras na praça comercial da Província do Rio de Janeiro, e que por isso não foram computadas no Quadro Companhias de Seguros em funcionamento na Província do Rio de Janeiro (1808-1889):

\subsection{The South British Fire and Marine Insurance Company of New Zealand:} seguradora situada em Auckland (Nova Zelândia), e garantia os riscos provenientes da navegação marítima e dos imanentes aos empreendimentos terrestres (incêndios). Localizamos apenas um único documento que a ela se 
referia: o Decreto $\mathrm{n}^{\circ} 10.116$, de 15 de dezembro de 1888 , o qual informava genericamente que a companhia estaria autorizada "a funcionar no Império". Além da autorização e das condições ao seu funcionamento no Brasil, o diploma anexara seus estatutos traduzidos para o português. Muito embora a tradução tenha sido feita por pessoa matriculada no Tribunal do Comércio da Corte ("Johannes Jochim Christian Voigt, corretor de navios, tradutor público juramentado e intérprete comercial"), consideramos que inexiste indícios suficientes à certificação da atuação da companhia na praça comercial da Província do Rio de Janeiro.

4.2 Norddeutscher Lloyd: companhia seguradora estabelecida em Bremen (Alemanha), e que contratava sobre os riscos provenientes da navegação marítima e fluvial. O único Decreto encontrado, o de $\mathrm{n}^{\circ} 10.195$, datado do dia 23 de fevereiro de 1889, autorizou a companhia "a funcionar no Império", mas não especificou se atuaria em todas as praças comerciais do Brasil, ou se especificamente em algumas delas. O diploma, além de autorizar o estabelecimento da seguradora e estipular as condições sob as quais suas agências deveriam operar, traz traduzido seus estatutos. E por mais que o tradutor o tivesse feito na "Nesta Muito Leal e Heróica Cidade do Rio de Janeiro", ainda assim nos faltariam elementos para certificar seu funcionamento nesta Província.

5) Casos de autorização de incorporação de companhias seguradoras, mas que inexiste informações que confirmem se foram levados a efeito:

5.1 Companhia de Seguro contra desastres: esta seguradora não compõe o Quadro das Companhias de Seguros em funcionamento na Província do Rio de Janeiro (1808-1889), pois, o único documento que nos forneceu alguma notícia de sua existência foi o Decreto $\mathrm{n}^{\mathrm{o}} 5.797$, de 18 de novembro de 1874, trata somente de conceder a Augusto Fromm a devida "autorização para organizar nesta Corte uma Companhia de seguros contra desastres". 
Ou seja, não autoriza seu funcionamento, muito menos aprova seus estatutos, somente informa que há a possibilidade de ser incorporada.

5.2 Companhia de Seguros de remissão do serviço militar: não foi inserida na listagem das companhias seguradoras, tendo em vista a incerteza de sua incorporação. Pois, a única fonte que noticiava a sua provável existência - o Decreto $n^{\circ}$ 6.066, de 18 de dezembro de 1875 - consistiu numa autorização para os requerentes Cunha, Pinto \& Comp. "incorporarem uma companhia de seguros de remissão do serviço do Exército", sem que fosse possível, portanto, conhecer se de fato a seguradora chegou a funcionar na praça comercial da Província do Rio de Janeiro.

6) Demais casos:

6.1 O Almanak Laemmert acusa que entre os anos de 1858 e 1861 funcionou uma agência na Rua Direita onde poderiam ser contratadas as apólices das companhias de seguros Nova Permanente (12), Fidelidade (11), Feliz Lembrança (44), Seguridade (40), Regeneração (17), e a partir de 1860 também as da Companhia de Seguro Marítimo Santa Cruz (41). Esta agência não compõe o Quadro, pois, se assim fosse, estaríamos computando duas vezes as mesmas seguradoras estabelecidas na praça mercantil do Rio de Janeiro. 


\section{ANEXO 4:}

\begin{tabular}{|c|c|c|c|}
\hline Série & Companhias & Quadro diretivo & Endereço \\
\hline $1(19)$ & $\begin{array}{l}\text { Companhia de Seguros } \\
\text { sobre a Vida dos Escravos } \\
\text { Prosperidade }\end{array}$ & $\begin{array}{l}\text { 1845: } \\
\text { (Diretor Gerente): Dr. B. Mure. } \\
\text { (Fiscais): Visconde de Olinda; Candido José de Araújo Vianna; } \\
\text { Euzebio de Queiroz Coutinho Mattoso da Camara. } \\
\text { (Administradores): José Victorino Ventura Pinheiro; João Vicente } \\
\text { Martins; Egidio Talloni. } \\
\text { (Secretario): E. Tiberghien }\end{array}$ & $\begin{array}{l}\text { 1845: } \\
\text { Escritório: r. de São José, } 59 .\end{array}$ \\
\hline $2(30)$ & $\begin{array}{l}\text { Companhia de Seguros } \\
\text { Previdência }\end{array}$ & $\begin{array}{l}\text { 1855: } \\
\text { (Gerentes): Carlos Le Blon; Estevão Bernard. } \\
\text { 1856: } \\
\text { (Diretores): Dr. João Manoel Pereira da Silva; Cons. Ângelo } \\
\text { Muniz da Silva Ferraz; Francisco José Gonçalves. } \\
\text { (Gerentes): Carlos Le Blon; Estevão Bernard. } \\
\text { (Médicos peritos): Dr. Jules Level; Dr. Pedro Maria de Almeida } \\
\text { Portugal. } \\
\text { (Médicos inspetores): Dr. Antonio Martins Pinheiro; Francisco } \\
\text { d'Assis da Silva Ferreira. } \\
\text { (Escritório) } \\
\text { (Caixa): Julio Bernard. } \\
\text { (Guarda Livros): Henrique do Carmo Edolo Junior. } \\
\text { (Secretário): Bento Manoel de Carrazedo. }\end{array}$ & $\begin{array}{l}\text { 1855-1859: } \\
\text { r. da Quitanda, } 54 .\end{array}$ \\
\hline
\end{tabular}




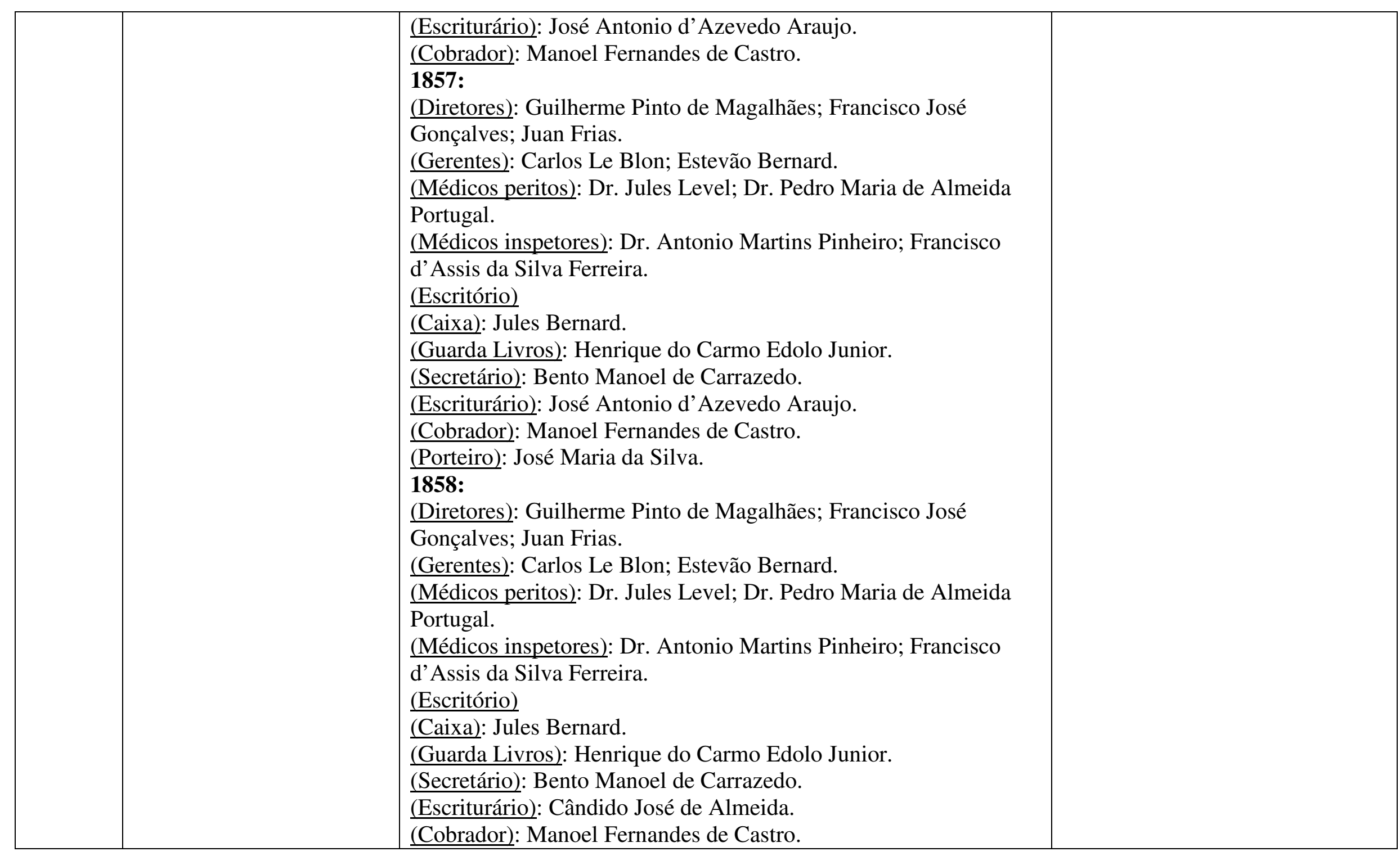




\begin{tabular}{|c|c|c|c|}
\hline & & $\begin{array}{l}\text { (Porteiro): José Maria da Silva. } \\
\text { 1859: } \\
\text { (Diretores): Guilherme Pinto de Magalhães; Francisco José } \\
\text { Gonçalves; Juan Frias. } \\
\text { (Gerentes): Carlos Le Blon; Estevão Bernard. } \\
\text { (Médico perito): Dr. Pedro Maria de Almeida Portugal. } \\
\text { (Médicos inspetores): Dr. Antonio Martins Pinheiro; Francisco } \\
\text { d'Assis da Silva Ferreira. } \\
\text { (Escritório) } \\
\text { (Caixa): Jules Bernard. } \\
\text { (Guarda Livros): Alfred Bernard. } \\
\text { (Secretário): Bento Manoel de Carrazedo. } \\
\text { (Cobradorírio): Cândido José de Almeida. } \\
\text { (Porteiro): José Maria da Silva. }\end{array}$ & \\
\hline $3(39)$ & $\begin{array}{l}\text { Companhia de Seguros } \\
\text { Tranquilidade }\end{array}$ & $\begin{array}{l}\text { 1855: } \\
\text { (Fundadores): Bernardo de Oliveira Mello; Luiz Carlos Adolpho } \\
\text { de Sousa (ambos nomeados gerentes) } \\
\text { 1858: } \\
\text { (Gerente): Bernardo de Oliveira Mello } \\
\end{array}$ & - \\
\hline $4(42)$ & $\begin{array}{l}\text { Companhia Mútua de } \\
\text { Seguros de vida de } \\
\text { escravos }\end{array}$ & $\begin{array}{l}\text { 1857: } \\
\text { (Gerentes): Lourenço José d'Aguiar; Gastão de Lailhucar. } \\
\text { 1858: } \\
\frac{\text { (Direção): Tenente Coronel Cândido José de Victoria (Diretor }}{\text { Anual). }} \\
\frac{\text { (Gerentes): Lourenço José d'Aguiar; Gastão de Lailhucar. }}{\text { "Há mais um conselho composto de } 11 \text { membros, do qual fazem }} \\
\text { parte os três senhores acima". } \\
\text { (Médicos): José Luis da Costa; Dr. F. F. Bustamante Sá; Dr. } \\
\text { Miguel Alves Villela. } \\
\text { (Empregados): Domingo Leandro P. Freitas; Fernando Pinto da }\end{array}$ & $\begin{array}{l}\text { 1857 - 1863: } \\
\text { r. do Hospício, } 236 . \\
\text { 1864: } \\
\text { r. de São Pedro, 2, } 1^{\text {o }} \text { andar. } \\
\text { 1865: } \\
\text { Escritório da Comissão } \\
\text { liquidadora : r. do Rosário, } 18 . \\
\text { 1866: } \\
\text { r. do Hospício, } 1^{\text {a }} \text {, sobrado. }\end{array}$ \\
\hline
\end{tabular}




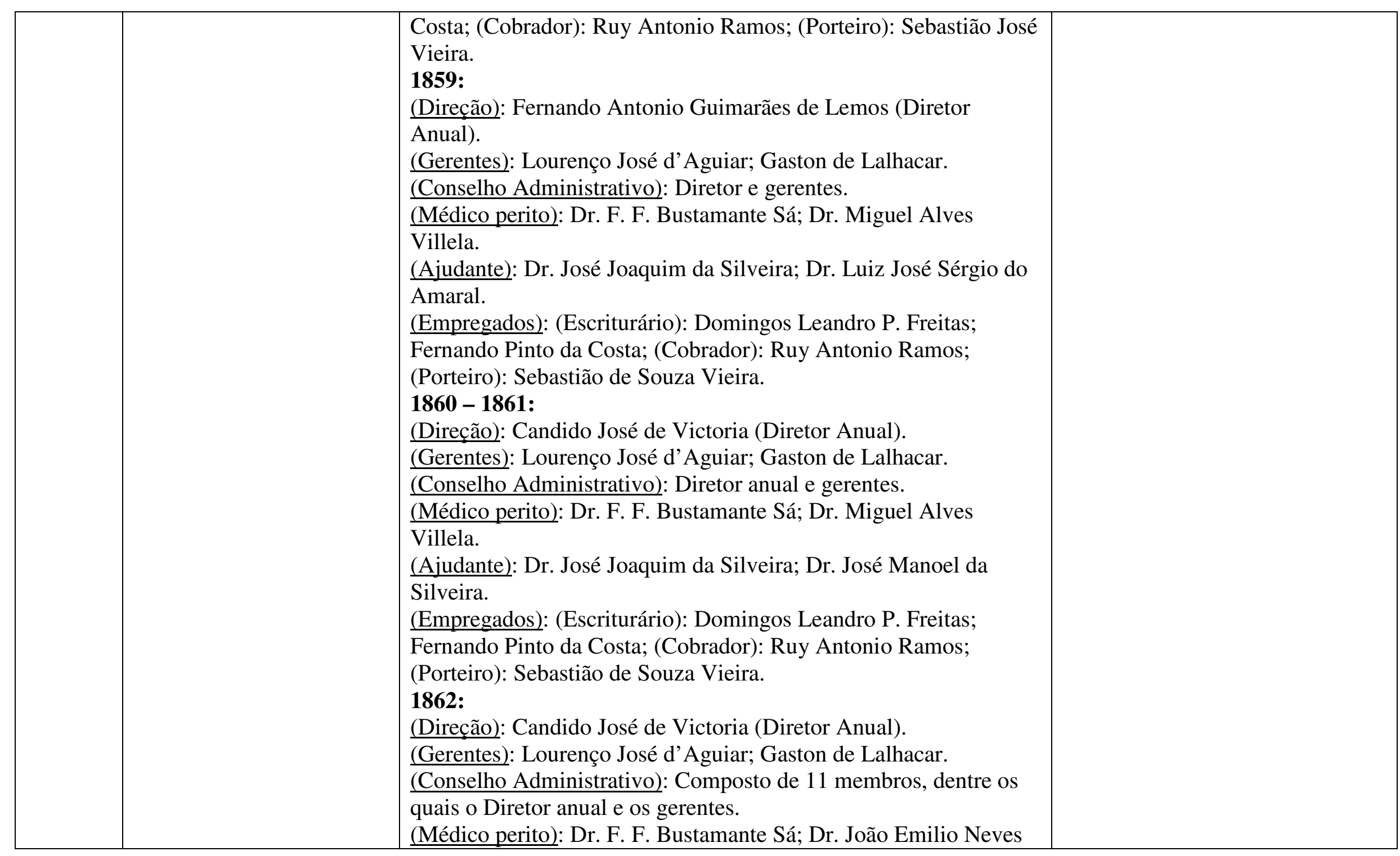




\begin{tabular}{|c|c|c|c|}
\hline & & 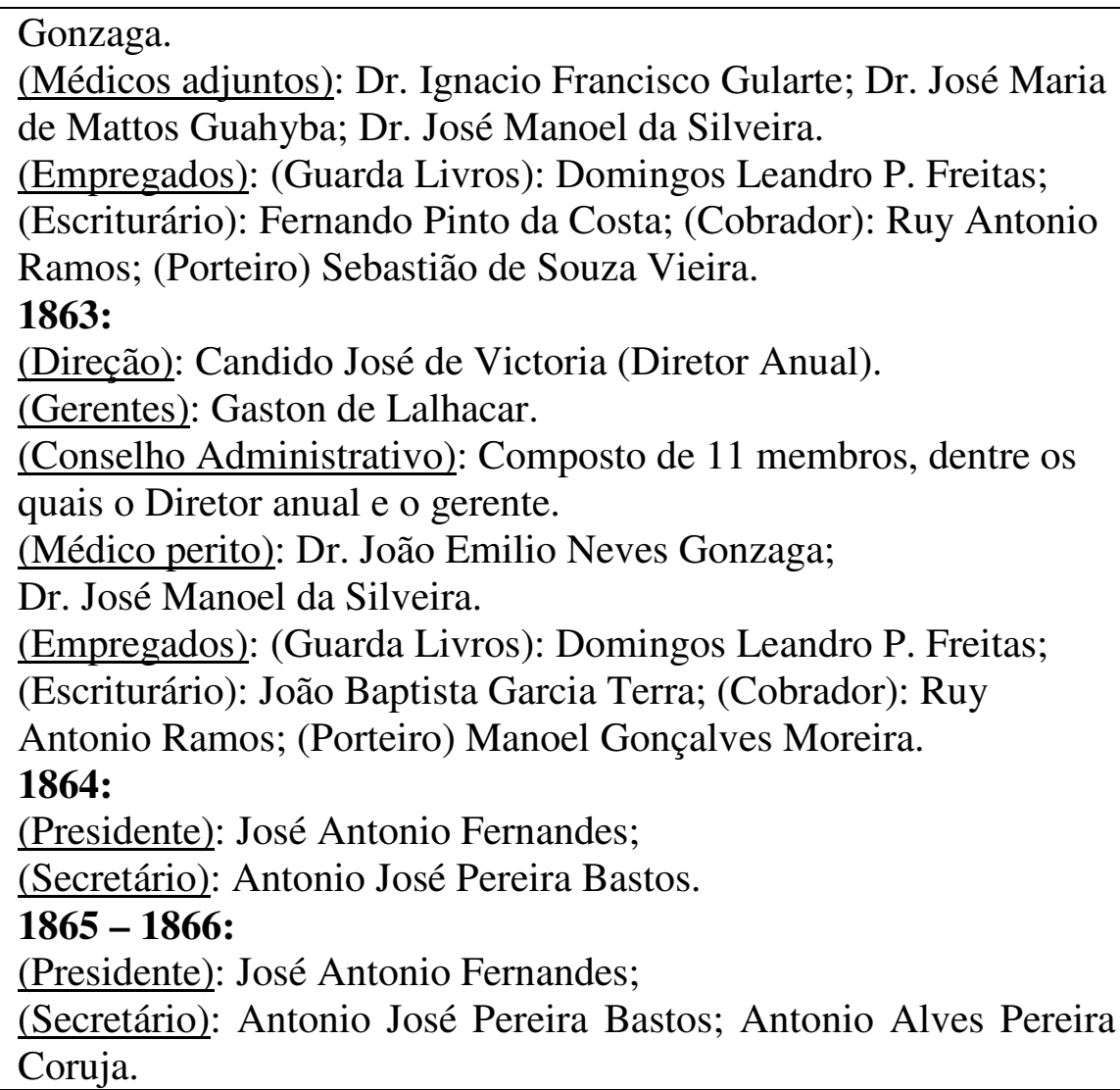 & \\
\hline $5(44)$ & $\begin{array}{l}\text { Companhia de Seguros } \\
\text { Marítimos e Terrestres } \\
\text { Feliz Lembrançal } \\
\text { Companhia Geral de } \\
\text { Seguros União }\end{array}$ & $\begin{array}{l}\text { 1857: } \\
\text { (Diretores): Cons. Francisco Borges Xavier de Lima; Dr. Cândido } \\
\text { José Cardoso; Hermenegildo Antonio Pinto. } \\
\text { 1858 - 1859: } \\
\text { (Diretoria): (Presidente): Cons. Francisco Borges Xavier de Lima; } \\
\text { (Secretário): Antonio Tertuliano dos Santos; (Caixa): Bernardino } \\
\text { Dias Pinheiro. } \\
\text { (Médicos da Companhia): Dr. José Ferreira (ou Pereira?) Rego; }\end{array}$ & $\begin{array}{l}\text { 1857: } \\
\text { Escritório: r. do Rosário, } 48 . \\
\text { 1858- 1869: } \\
\text { Escritório: r. Direita, } 48 . \\
\text { 1870: } \\
\text { r. Candelária, } 09 . \\
\text { 1871: } \\
\text { Escritório: r. de S. Pedro, 53, }\end{array}$ \\
\hline
\end{tabular}




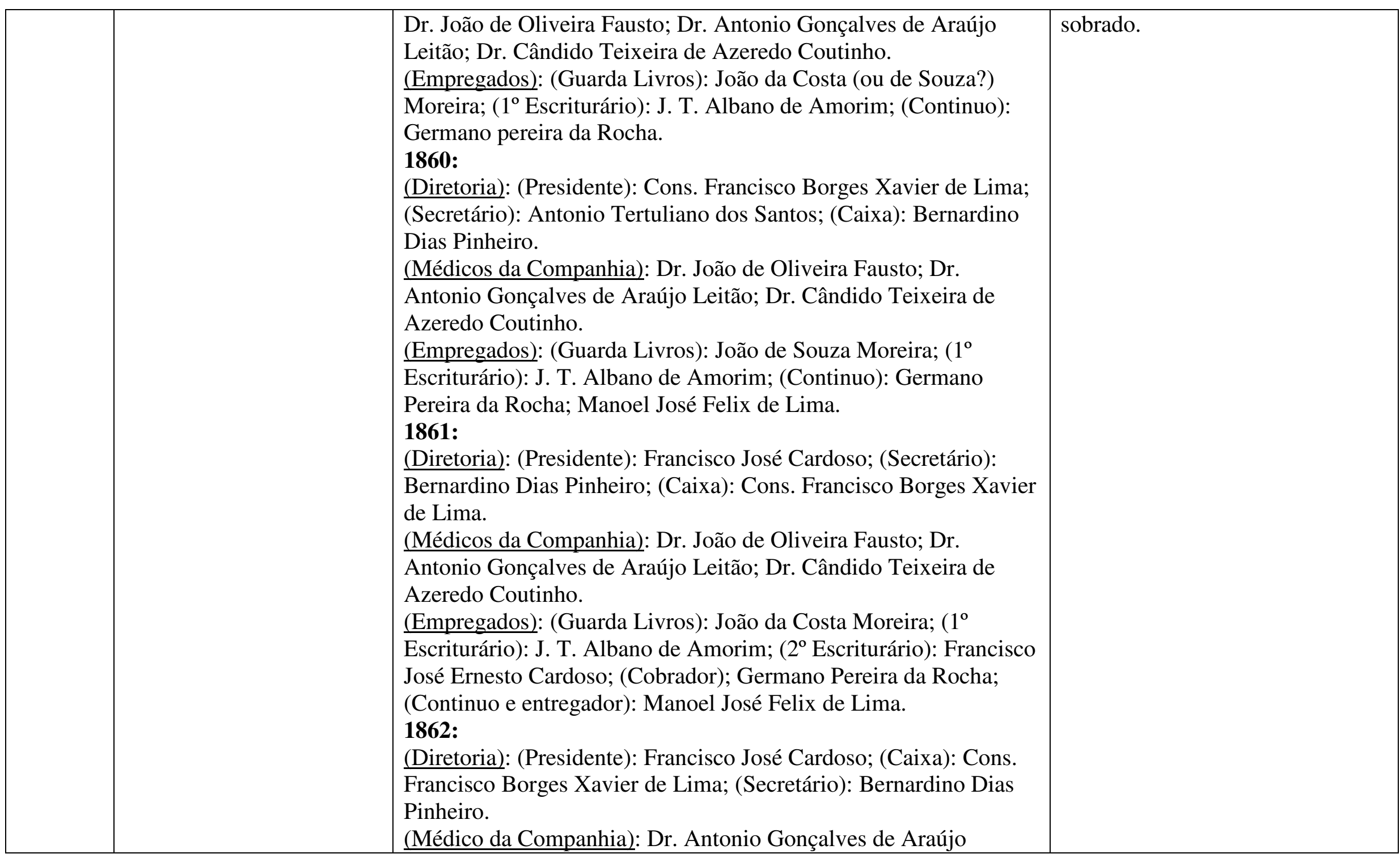




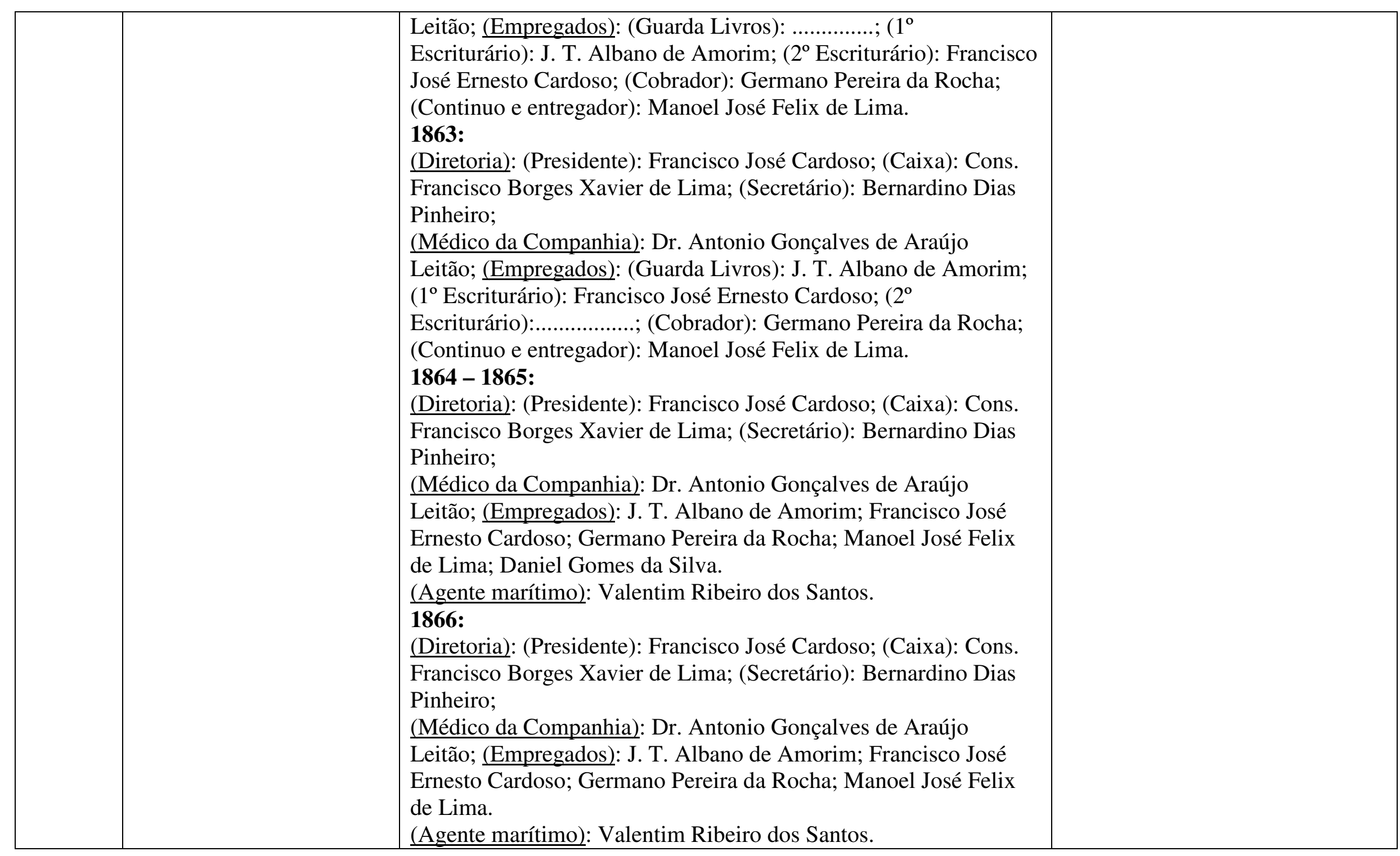




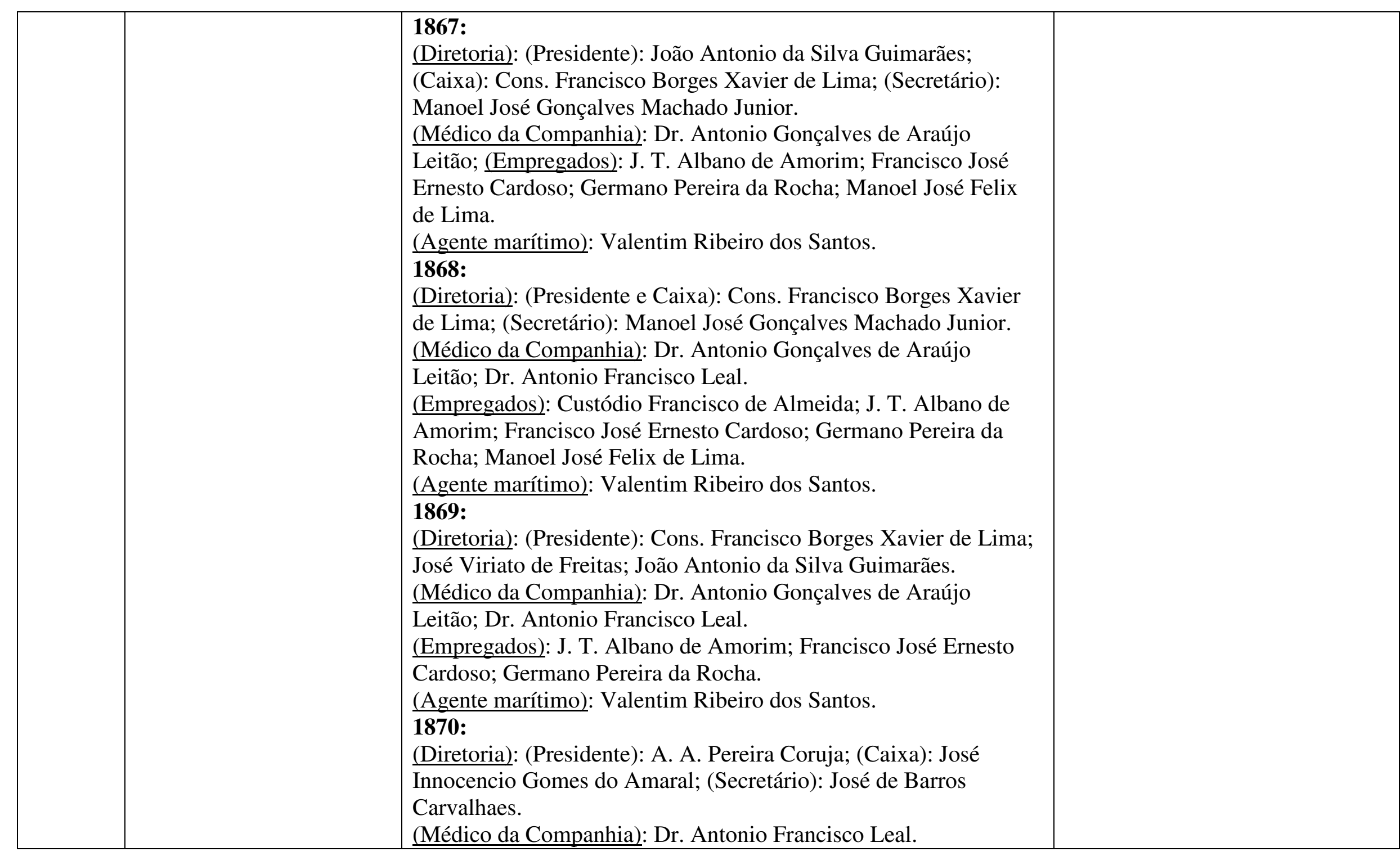




\begin{tabular}{|c|c|c|c|}
\hline & & $\begin{array}{l}\text { (Empregados): J. T. Albano de Amorim; Francisco José Ernesto } \\
\text { Cardoso; J. P. Amorim da Costa; Germano Pereira da Rocha; } \\
\text { Vicente Marques Dias de Castro; João de Azevedo da Costa } \\
\text { Pereira. } \\
\text { (Agente marítimo): Valentim Ribeiro dos Santos. } \\
\text { 1871: } \\
\text { (Diretoria): (Presidente): Antonio Calazans Raythe; (Caixa); } \\
\text { Albino Alvim du Rocher; (Secretário): José de Barros Carvalhaes. } \\
\text { (Médico da Companhia): Dr. Francisco Correa Leal. } \\
\text { (Empregados): J. P. Amorim da Costa. } \\
\text { (Agente marítimo): Valentim Ribeiro dos Santos. } \\
\text { 1872: } \\
\text { (Diretoria): (Presidente): Antonio Calazans Raythe; (Caixa); } \\
\text { Albino Alvim du Rocher; (Secretário): José de Barros Carvalhaes. }\end{array}$ & \\
\hline $6(52)$ & $\begin{array}{l}\text { Companhia de Seguros } \\
\text { Util-Previdência }\end{array}$ & $\begin{array}{l}\text { 1860: } \\
\text { (Diretores): Guilherme Pinto de Magalhães; Francisco José } \\
\text { Gonçalves; João Paulino de Azevedo e Castro. } \\
\text { (Gerente): E. Bernard. }\end{array}$ & $\begin{array}{l}\text { 1860: } \\
\text { r. da Quitanda, } 54 .\end{array}$ \\
\hline $7(71)$ & $\begin{array}{l}\text { Companhia de Seguros } \\
\text { União Fluminense }\end{array}$ & $\begin{array}{l}\text { 1870: } \\
\text { (Administração): (Diretor): José de Souza Leite Ribeiro; } \\
\text { (Secretário): Dr. José da Silveira Torres; (Diretor Gerente): Dr. } \\
\text { José Joaquim de Souza Ayram Martins. } \\
\text { (Conselho Fiscal): João José de França; João Chrysostomo da } \\
\text { Costa Guimarães; Luiz Barbosa de Mendonça. } \\
\text { (Médico): Dr. José Manoel da Silveira. } \\
\text { (Escriturário): João de Araújo Palhas. } \\
\text { 1871: } \\
\text { (Administração): (Diretor Presidente): José de Souza Leite } \\
\text { Ribeiro; (Secretário): Dr. José da Silveira Torres; (Diretor } \\
\text { Gerente): Dr. José Joaquim de Souza Ayram Martins. } \\
\text { (Conselho Fiscal): João José de França; João Chrysostomo da }\end{array}$ & $\begin{array}{l}\text { 1870: } \\
\text { r. do Sacramento, 19, em frente à } \\
\text { Igreja. }\end{array}$ \\
\hline
\end{tabular}




\begin{tabular}{|c|c|c|c|}
\hline & & $\begin{array}{l}\text { Costa Guimarães; Luiz Barbosa de Mendonça. } \\
\text { (Médico): Dr. José Manoel da Silveira. } \\
\text { (Escriturário): Dr. José Joaquim de Souza Ayram Martins. }\end{array}$ & \\
\hline $8(77)$ & $\begin{array}{l}\text { Companhia de Seguros } \\
\text { Perseverança }\end{array}$ & $\begin{array}{l}\text { 1873: } \\
\text { (Agentes no RJ): Leôncio \& Mello. } \\
\text { 1874: } \\
\text { (Diretoria): Rufino Gomes de Oliveira; Francisco Augusto de } \\
\text { Oliveira; Jeronyno Joaquim de Oliveira. } \\
\text { (Conselho Fiscal): José Joaquim de Moraes; João Antonio de } \\
\text { Lima; Elias Antonio de Lima. } \\
\text { 1877: } \\
\text { (Agentes): Gouvêa Mendonça \& Lopes. } \\
\text { 1879- 1887: } \\
\text { (Agentes): Guimarães \& Ferreira. } \\
\text { 1888: } \\
\text { (Diretores): Francisco José Ribeiro de Barros; Antonio José } \\
\text { Ferreira Martins Filho; Jeronymo Joaquim de Oliveira. } \\
\text { (Conselho Fiscal): Francisco Eugenio Carneiro; Luiz Chrysostomo } \\
\text { de Oliveira; João Francisco Ribeiro. } \\
\text { (Empregados): (guarda-livros): Francisco de Paula Carneiro; } \\
\text { (ajude do guarda-livros): José Gomes Leite. }\end{array}$ & $\begin{array}{l}\text { 1873: } \\
\text { r. Primeiro de Março, 127, } 1^{\circ} \\
\text { andar. } \\
\text { 1874: } \\
\text { r. Primeiro de Março, 109, } 1^{\circ} \\
\text { andar. } \\
\text { 1877: } \\
\text { r. do Rosário, } 100 . \\
\text { 1878 - 1888: } \\
\text { r. Primeiro de Março, } 41 .\end{array}$ \\
\hline $9(98)$ & $\begin{array}{l}\text { Companhia Garantidora } \\
\text { de Vidas }\end{array}$ & $\begin{array}{l}\text { 1876: } \\
\text { (Diretoria): (Presidente): Dr. Aristides F. Garnier; (Tesoureiro): } \\
\text { Dr. A. Pinheiro Guedes; (Secretário): Dr. Guilherme P. S. } \\
\text { Belmonte; (Gerente): F. J. Ernesto Cardoso; (Sub-gerente): J. F. } \\
\text { Polycarpo; } \\
\text { (Médicos):............ }\end{array}$ & $\begin{array}{l}\text { 1876: } \\
\text { r. do general Câmara, } 123 .\end{array}$ \\
\hline $10(99)$ & $\begin{array}{l}\text { Companhia de Seguros } \\
\text { Mútuos União }\end{array}$ & $\begin{array}{l}\text { 1875: } \\
\text { (Conselho Fiscal): Comendador Antonio Joaquim Soares Ribeiro; } \\
\text { Dr. Antonio Marcolino Fragoso; Dr. Luiz José de Carvalho e } \\
\text { Mello Mattos. }\end{array}$ & $\begin{array}{l}\text { 1875: } \\
\text { Largo do Rosário, } 34 . \\
\text { 1876: } \\
\text { r. Primeiro de Março, } 129 .\end{array}$ \\
\hline
\end{tabular}




\begin{tabular}{|c|c|c|c|}
\hline & & $\begin{array}{l}\text { (Diretores): Dr. Manoel de Almeida de Macedo Sodré; } \\
\text { Luiz de Soubiron. } \\
\text { (Médicos): Dr. João Emílio Neves Gonzaga; Dr. Pedro Isidoro de } \\
\text { Moraes; Dr. Fernando Francisco da Costa Ferraz. } \\
\text { (Advogado): Dr. Theodoro de Macedo Sodré. } \\
\text { (Corretor): José Pedro de Souza Meirelles. } \\
\text { (Banqueiro): Banco do Brasil. } \\
\text { 1876: } \\
\text { (Conselho Fiscal): Comendador Antonio Joaquim Soares Ribeiro; } \\
\text { Dr. Antonio Marcolino Fragoso; Dr. Luiz José de Carvalho e } \\
\text { Mello Mattos. } \\
\text { (Junta Diretora): Visconde de Arcozello; Dr. Joaquim de Almeida } \\
\text { Ramos; Honório de Araújo Maia. } \\
\text { (Médicos): Dr. João Emílio Neves Gonzaga. } \\
\text { (Advogado): Dr. Theodoro de Macedo Sodré. } \\
\text { (Corretor): José Pedro de Souza Meirelles. } \\
\text { (Banqueiro): Banco do Brasil. } \\
\text { 1878- 1879: } \\
\text { (Conselho Fiscal): Comendador Antonio Joaquim Soares Ribeiro; } \\
\text { Dr. Antonio Marcolino Fragoso; Dr. Luiz José de Carvalho e } \\
\text { Mello Mattos. } \\
\text { (Junta Diretora): João Alvares de Azevedo Macedo; Dr. Joaquim } \\
\text { de Almeida Ramos; Ponciano Vieira de Araújo Machado. } \\
\text { (Médicos): Dr. Pedro Izidro de Moraes. } \\
\text { (Banqueiro): Banco do Brasil. } \\
\text { (Diretor-Gerente): Dr. Manoel de Almeida Macedo Sodré. } \\
\text { 1880: } \\
\text { (Conselho Fiscal): Dr. Francisco Maria Corrêa de Sá e Benevides; } \\
\text { Tenente-Coronel Luiz José da Costa; Manoel Thiago Ferreira } \\
\text { Resende. } \\
\text { (Suplentes): Manoel Ferreira Machado Guimarães; José Maria da }\end{array}$ & $\begin{array}{l}\text { 1878-1879: } \\
\text { r. Municipal, } 02 . \\
\text { 1880: } \\
\text { r. do Sacramento, 12, sobrado. }\end{array}$ \\
\hline
\end{tabular}




\begin{tabular}{|l|l|l|l|}
\hline & & $\begin{array}{l}\text { Silva Guimarães. } \\
\text { (Diretor Geral): Comendador Manoel José Cardoso. }\end{array}$ & \\
$\begin{array}{l}\text { (Gerente): Joaquim José Moreira Monteiro. } \\
\text { (Banqueiro): Banco do Brasil. }\end{array}$ & \\
\hline $11(107)$ & A Equitativa Brasileira & - & - \\
\hline
\end{tabular}

Fonte: Almanak administrativo, mercantil e industrial do Rio de Janeiro - Almanak Laemmert. 1844-1889.

Obs. 1: os números entre parênteses que vão após o dígito de identificação de cada companhia correspondem à posição que elas podem ser encontradas no Quadro Companhias de Seguros em funcionamento na Província do Rio de Janeiro (1808-1889), cf. Anexo 2.

Obs. 2: as informações referentes às Companhia de Seguros Tranquilidade foram extraídas do Decreto ${ }^{\circ} 1.669$ de 7 de novembro de 1855 , e do Decreto ${ }^{\circ} 2.101$ de 6 de fevereiro de 1858 . 


\section{ANEXO 5:}

Modelo de apólice da Companhia de Seguros Feliz Lembrança para a contratação de seguros de vida de escravos

\section{SEGUROS DE ESCRAVOS ${ }^{201}$}

COMPANHIA DE SEGUROS

\section{Feliz Lembrança}

Autorizada por Dec. n. 2077 - de 16 de Janeiro de 1858

CAPITAL 2.000:000\$000

Apólice de seguro de escravos n.

Prêmio de - \% rs. $\$$

Valor segurado rs. $\$$

Apólice e sello rs. \$

(No anverso)

Rio de janeiro... de... de... 18... à... hora da...

A Companhia Geral dos Seguros Feliz Lembrança por um de seus Diretores abaixo assinado, segura por tempo de um ano que há de findar às doze horas do dia... ao Sr.... morador em... o escravo cujos sinais ficam à margem, avaliado em...

(No verso)

\section{CONDIÇÕES GERAIS DO SEGURO}

\section{Restrição do Seguro}

Art. $1^{\circ} \mathrm{O}$ Seguro não pode jamais ser uma origem de lucro para o Segurado; ele não garante senão a indenização das perdas reais; mas em nenhum caso além do valor da Apólice; por consequência o valor da Apólice ou prêmios recebidos não podem ser invocados nem opostos pelo Segurado como prova da existência ou valor dos objetos seguros, seja no momento do seguro, seja no do sinistro.

\section{Anulação do contrato}

Art. $2^{\circ}$ Toda a reticência, toda a falsa declaração da parte do Segurado, ou falta de participação em caso de agravação de risco, anula o contrato.

${ }^{201}$ Cf. LISBOA, José da Silva, Visconde de Cairu. Princípios de direito mercantil e leis de marinha, p. 183185. Dentre as apólices negociadas na praça do Rio de Janeiro, Cândido Mendes de Almeida optou por anexar as fórmulas das apólices da Companhia de Seguros Feliz Lembrança - para os seguros marítimos, terrestres e de vida de escravos - por entender "serem as condições em maior número e mais minuciosas". No verso da apólice, aonde iam impressas as condições, havia espaço suficiente para o ajuste de tantas mais quantas fossem ajustadas. Aqui optamos por transcrever somente a fórmula da apólice correspondente ao seguro de vida de escravos. 


\section{Notas das participações na Apólice}

Art. $3^{\circ}$ Quando nas condições especiais se estabelecer a necessidade de fazer participação à Companhia, ou de seu consentimento, só poderá provar-se por escrito assinado por um dos Diretores.

Fica subentendido que esta disposição é extensiva aos agentes da Companhia naquilo que couber na sua alçada.

\section{Prescrição}

Art. $4^{\circ}$ Prescreve o direito de reclamação da parte do Segurado, dentro de um ano depois de acontecido o sinistro, ou notícia dele.

\section{Árbitros}

Art. $5^{\circ}$ Todas as contestações serão resolvidas por dois Árbitros nomeados, um pela Companhia, e outro pela parte dissidente.

Depois da intimação para nomeação dos Árbitros, se a parte intimada a não fizer dentro de trinta dias, poderá a outra parte requerer ao meritíssimo Tribunal do Comércio que faça a nomeação ex-offício.

O mesmo Tribunal nomeará o terceiro Árbitro, sendo que haja discordância na decisão dos dois primeiramente nomeados. Deve o terceiro Árbitro adotar um dos votos divergentes, e a sua deliberação será terminante (ficando direito salvo de recurso para o Juízo competente). Arts. 33 e 36 dos Estatutos.

\section{Código Comercial}

Art. $6^{\circ}$ Em tudo que não for previsto nas condições da Apólice, prevalece o disposto no Cod. Com., sendo mesmo extensivo a toda a espécie de Seguro naquilo em que for aplicável, e com que tiver analogia.

A Companhia, se for condenada por sentença, e esta se achar apelada, ainda que sem efeito suspensivo, não poderá ser obrigada a pagar nem receber a depósito a importância do Seguro senão depois de confirmada a sentença pelos Tribunais superiores, não havendo mais recurso.

\section{CONDIÇÕES ESPECIAIS DO SEGURO DE ESCRAVOS}

\section{Riscos garantidos e não garantidos}

Art. $1^{\circ}$ A Companhia toma a si o risco de morte de escravos de ambos os sexos, contanto que não proceda de maus tratos, ou sevícias de seus Senhores, ou suicídio que se reconheça por causa de maus tratos, ainda mesmo por parte da Autoridade.

\section{Começo e fim dos riscos}

Art. $2^{\circ} \mathrm{O}$ começo e fim dos riscos será ao meio dia dos dias designados pelo ajuste; porém nunca o risco começará antes do momento da assinatura da Apólice.

Estado de saúde exigido 
Art. $3^{\circ}$ O Seguro é feito sobre a presunção de que o escravo goza de um estado ordinário de saúde: por consequência, o Seguro deve declarar, debaixo de juramento, se julga o escravo ou escravos a segurar em estado de saúde, ou se sabe que alguma doença oculta o compromete.

\section{Agravação de risco}

Art. $4^{\circ}$ Poderão ser admitidos ao Seguro, se se julgar razoável com um aumento de prêmio, segundo a avaliação dos Médicos da Companhia, escravos com alguma indisposição passageira que não afete os órgãos essências à vida, e também a gravidez.

Os escravos cujo ofício seja danoso ou arriscado, como foguistas, padeiros, empregados em fundições, catraeiros, etc., pagarão mais um por cento do seu valor, além do prêmio ordinário.

Falecendo qualquer escrava em consequência do parto, abater-se-á $200 \$ 000$ na indenização, bem como $30 \%$ no caso de falecer de cólera, ou aquilo que se ajustar.

\section{Transferência}

Art. $5^{\circ}$ As Apólices não serão transferíveis por via de endosso.

No caso de herança, venda ou doação, o novo proprietário sucede ao Segurado nos mesmos direitos e obrigações da Apólice, mediante participação à Companhia, e seu consentimento.

A Companhia receberá $5 \$ 000$ por averbar a transferência de cada Apólice.

\section{Declarações e participações}

Art. $6^{\circ}$ Para efetuar o Seguro deverá o pretendente apresentar uma minuta assinada, declarando o seu domicílio e o número dos escravos que pretende segurar, com o nome, idade certa ou presumida, cor, nação, ofício e valor de cada um.

No caso do escravo ir para algum Hospital, ou Casa de Detenção, o Segurado deverá logo participá-lo à Companhia.

O escravo não pode fazer uma residência definitiva, pena de rescisão do contrato, fora do Município da Companhia (e por extensão em Niteroi), ou em que a Companhia tenha estabelecido Agências, devendo em tal caso levar uma guia da Companhia ou Agência onde tiver sido segurado, para ser apresentada à Agência em cujo Município for residir: porém uma ausência temporária que não exceda a trinta dias é permitida, com participação prévia; no caso de morte, durante tal ausência, ela será atestada pelo Médico, Vigário e Subdelegado do Lugar, com quaisquer sinais particulares que possam fazer reconhecer a identidade da pessoa.

Em caso de sinistro deve o Segurado participar imediatamente à Companhia, para que um dos seus Médicos verifique a identidade do escravo, e apresentará certidão do Médico que assistirá o escravo, ou do Hospital em que tenha falecido que faça constar a causa da morte.

O Segurado decai de todo o direito se nas suas declarações e participações ocultar, dissimular, ou de qualquer modo alterar a verdade, ou apresentar quaisquer documentos falsos. 
Art. $7^{\circ}$ A avaliação será feita pela Diretoria, tomando-se sempre o mínimo do valor dos escravos, e ouvido o parecer dos Médicos no exame sanitário.

É pois necessário que os escravos a segurar sejam apresentados no escritório da Companhia, das 10 horas da manhã às 2 da tarde.

\section{Prêmio}

Art. $8^{\circ} \mathrm{O}$ prêmio será pago à vista no ato da entrada da Apólice até a quantia de $100 \$ 000$; e metade à vista, metade em letra quando exceder esta quantia, salvo outra convenção.

O Segurado que faltar ao pagamento do prêmio em dinheiro ou em letra no seu vencimento, desonera a Companhia de toda a responsabilidade, ficando a esta o direito da cobrança.

\section{Pagamento dos sinistros}

Art. $9^{\circ}$ Provado que seja o falecimento do escravo, a Companhia indenizará o Segurado no prazo de quinze dias, deduzindo-se três por cento para o custo da certidão de identidade passada pelo Médico da Companhia, incluindo-se no pagamento as letras que tiver o Segurado ainda mesmo não vencidas.

\section{Nulidade do Seguro}

Art. 10 É nulo o Seguro sobre um escravo que esteja seguro por outrem.

\section{Tarifa dos prêmios para o Seguro de escravos nos casos ordinários}
Idade
Prêmio

De 4 a 5 anos.

De 5 a 8

"

11 por cento

De 8 a 10

De 10 a 12

De 12 a 40

De 40 a 45

De 45 a 50

De 50 a 55

De 55 a 60

De 60 a 65

$\begin{array}{ll}9 & \text { ، } \\ 8 & \text { ، } \\ 6 & \text { ، } \\ 41 / 2 & \text { ، } \\ 51 / 2 & \text { “ } \\ 61 / 2 & \text { “ } \\ 71 / 2 & \text { ، } \\ 91 / 2 & \text { “ } \\ 151 / 2 & \text { ، }\end{array}$

Para firmeza, e constar onde convier, lavrou-se a presente Apólice, pela qual nos obrigamos, Segurador e Segurado, ao cumprimento das condições nelas exaradas, que aceitamos, e queremos que valham independentemente e sem embargo de quaisquer disposições e estilos em contrário.

Pagou de selo... \$...

Pela Companhia Feliz Lembrança

O DIRETOR 